Golden Gate University School of Law

GGU Law Digital Commons

Theses and Dissertations

Student Scholarship

$11-30-2020$

\title{
Human Rights In the Context of Sustainable Development
}

Kuruvilla Mathen

Golden Gate University School of Law, kuruvilla2@comcast.net

Follow this and additional works at: https://digitalcommons.law.ggu.edu/theses

Part of the Human Rights Law Commons, and the International Humanitarian Law Commons

\section{Recommended Citation}

Mathen, Kuruvilla, "Human Rights In the Context of Sustainable Development" (2020). Theses and Dissertations. 83.

https://digitalcommons.law.ggu.edu/theses/83

This Dissertation is brought to you for free and open access by the Student Scholarship at GGU Law Digital Commons. It has been accepted for inclusion in Theses and Dissertations by an authorized administrator of GGU Law Digital Commons. For more information, please contact jfischer@ggu.edu. 


\section{GOLDEN GATE UNIVERSITY SCHOOL OF LAW}

DISSERTATION TITLE: HUMAN RIGHTS IN THE

CONTEXT OF SUSTAINABLE DEVELOPMENT

APPLICANT: KURUVILLA MATHEN

SUBMITTED TO GOLDEN GATE UNIVERSITY SCHOOL OF LAW，DEPARTMENT OF INTERNATIONAL LEGAL STUDIES, IN PARTIAL FULFILLMENT OF THE REQUIREMENTS FOR THE CONFERMENT OF THE DEGREE OF SCIENTIAE JURIDICAE DOCTOR (SJD).

MEMBERS OF THE DISSERTATION COMMITTEE

1. DR. MARC SANTAMARIA

2. PROFESSOR DR. ZAKIA AFRIN

3. DR. ROBERT FRAZIER

SAN FRANCISCO, CALIFORNIA

NOVEMBER 30, 2020 


\section{HUMAN RIGHTS IN THE CONTEXT \\ OF SUSTAINABLE DEVELOPMENT}

\section{Table of Contents}

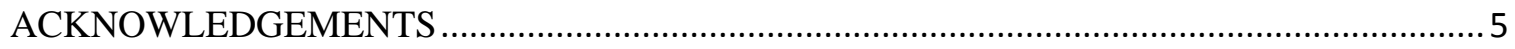

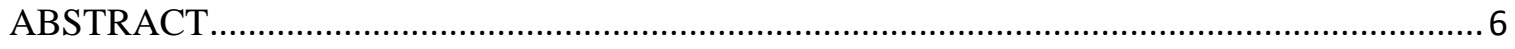

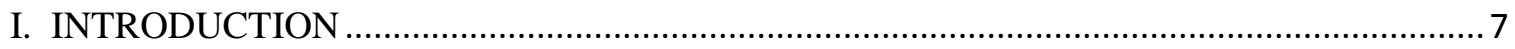

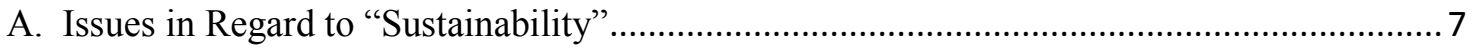

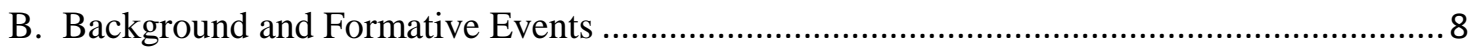

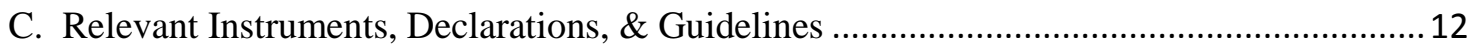

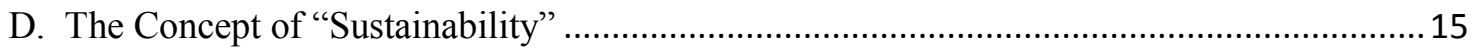

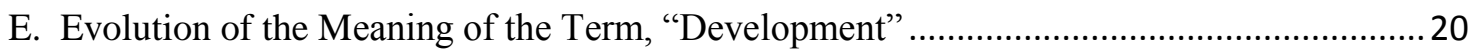

F. A Brief History of Environmental and Related Initiatives ............................................. 22

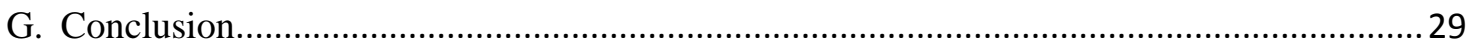

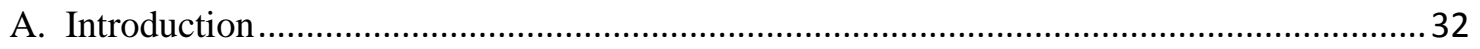

B. Symptoms, Causes, \& Consequences of Climate Change …............................................... 32

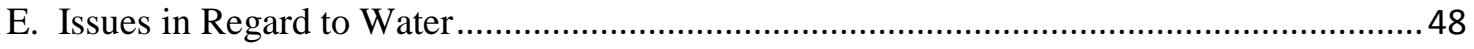

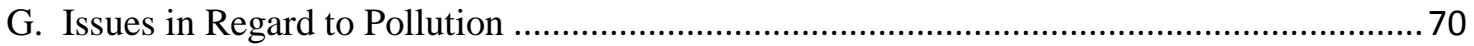

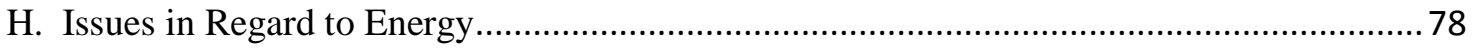

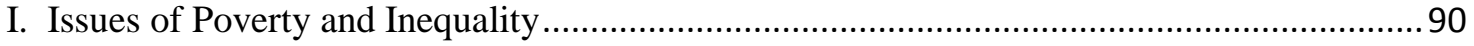

J. Contestations of Anthropogenic Causes of Climate Change............................................. 101

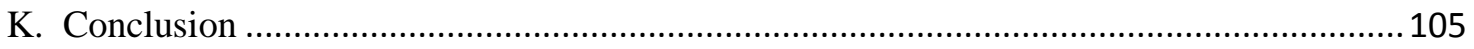

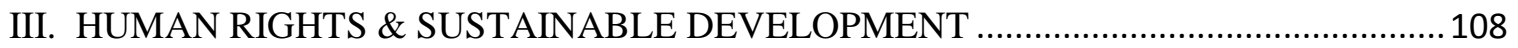

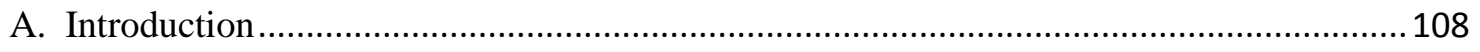

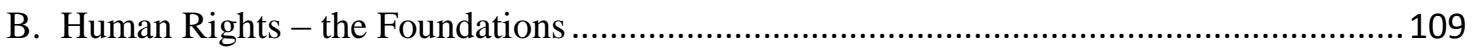

C. The U.N. Charter \& Legal Obligations to Preserve \& Promote Human Rights................. 111 
D. The Protection of the Environment as a Human Right

1. Amnesty International: Environmental Factors and Human Rights ............................. 118

2. Human Rights Watch (HRW): Environmental Factors and Human Rights.................... 120

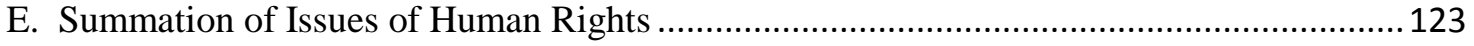

F. The Substantive Content of the Sustainable Development Goals (SDGs) ......................... 125

G. Examination and Evaluation of Sustainable Development Goals (SDGs)........................172

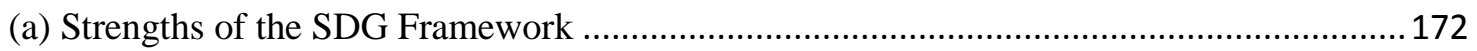

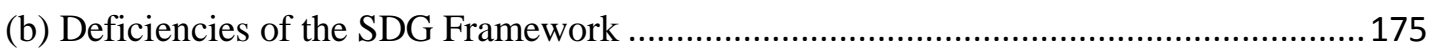

(c) Overall Assessment of the SDG Framework............................................................ 195

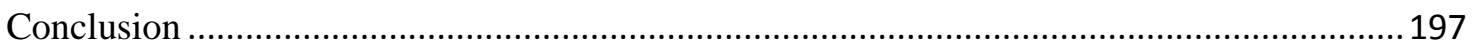

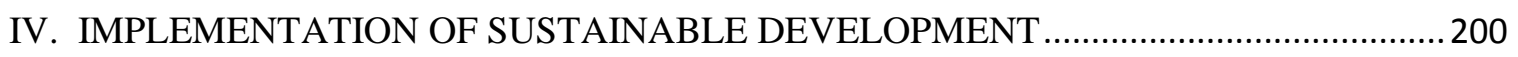

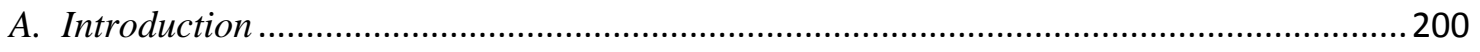

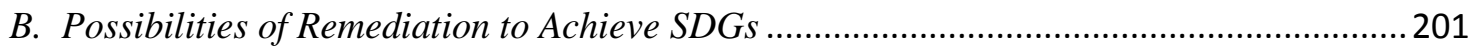

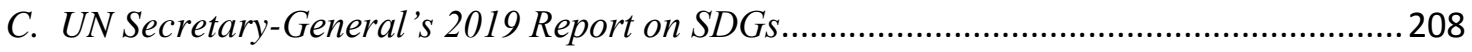

D. Appointment of 17 SDG Advocates by UN Secretary-General ..........................................209

E. Serious Reported Deficiencies in Implementation of SDGs ...........................................211

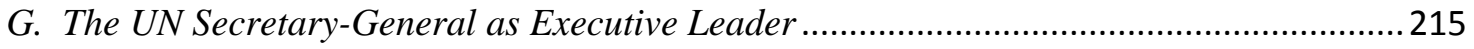

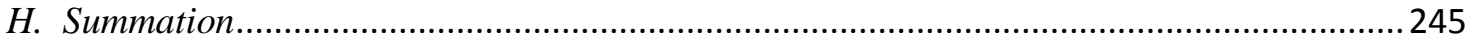

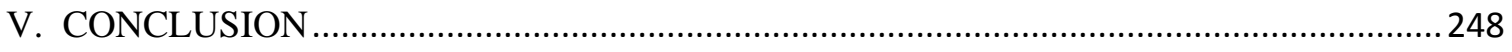

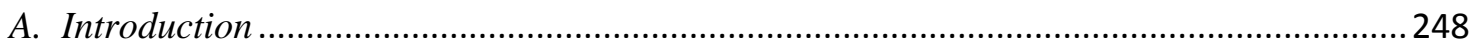

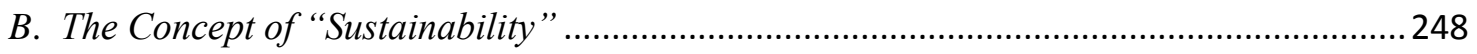

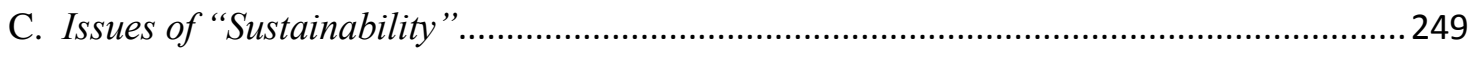

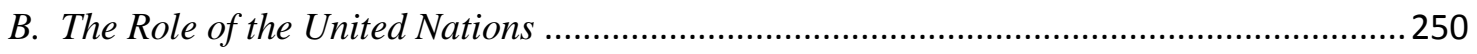

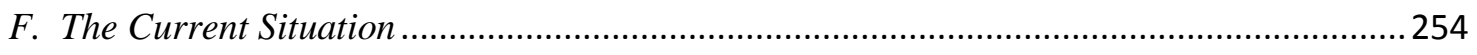

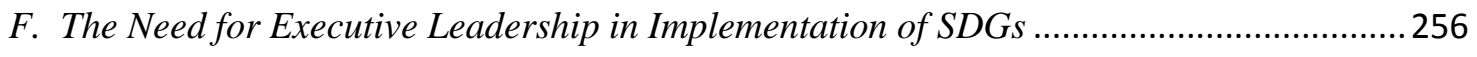


VI. BIBLIOGRAPHY 


\section{ACKNOWLEDGEMENTS}

I would like to record here my debt of gratitude to Professor Dr. Christian Nwachukwu Okeke, head of the Department of International Legal Studies at Golden Gate University School of Law, San Francisco, U.S.A, and my leader and mentor in the completion of this dissertation, submitted in partial fulfillment of the requirements of the degree of Doctor of Juridical Science (S.J.D) at Golden Gate University. Professor Dr. Okeke's incomparable knowledge and understanding of the complexities of International Law, and his great qualities as a leader and mentor were the main factors in my undertaking this course of study.

Further, I would like to record my debt of gratitude to the distinguished members of my Dissertation Committee: Dr. Marc Santamaria, Professor Dr. Zakia Afrin, and Dr. Robert Frazier, members of the faculty of Golden Gate University School of Law, San Francisco.

Kuruvilla Mathen San Francisco, CA

November 9, 2020 


\begin{abstract}
$\underline{\text { ABSTRACT }}$
The conceptual framework of "Sustainable Development," with its three dimensions of economic growth, social development, and environmental protection, represents the result of several significant and far-reaching initiatives. On September 25, 2015, the United Nations General Assembly adopted Resolution A/RES/70/1, "Tran"sforming Our World: the 2030 Agenda for Sustainable Development." Resolution A/RES/70/1 propounded seventeen "Sustainable Development Goals (SDGs) and 169 targets," with a planned implementation date of 2030.

This study examines issues of sustainable development. It presents arguments that the framework of sustainable development, in its economic, social, and environmental dimensions, encompasses legally cognizable human rights, grounded in provisions and principles of the U.N. Charter and the International Bill of Human Rights, and informed by provisions and principles of major international instruments and declarations. This work presents a critical evaluation of the seventeen goals stated in Resolution A/RES/70/1.

In view of the immense scope of the tasks anticipated, and major delays hitherto experienced in implementation, it is suggested that the project be coordinated by an entity possessed of breadth of vision, nd qualities of neutrality, ndependence, and unimpeachable integrity. In light of the possibility that issues raised may implicate the maintenance of international peace and security, it is suggested that an appropriate controlling and implementing agency be led by the Secretary-General of the U.N., supported by committees of experts in key functional areas.
\end{abstract}




\section{HUMAN RIGHTS IN THE CONTEXT \\ OF SUSTAINABLE DEVELOPMENT}

\section{INTRODUCTION}

\section{A. Issues in Regard to "Sustainability"}

The conceptual framework of "Sustainable Development," with its three Dimensions of economic growth, social development, and environmental protection, represents the result of several significant and far-reaching initiatives. On September 25, 2015, the U.N. General Assembly adopted Resolution A/RES/70/1, "Transforming Our World: the 2030 Agenda for Sustainable Development."1 Resolution A/RES/70/1 stated seventeen "Sustainable Development Goals (SDGs) and 169 targets."2

Part I of this study surveys the evolutionary history and implementation potentialities of the complex, multi-dimensioned framework, "Sustainable Development," with its three interrelated components of economic growth, social development, and environmental protection. The primary objectives of this work are as follows:

(a) Present arguments that the framework of Sustainable Development encompasses legally cognizable human rights, grounded in provisions and principles of the U.N. Charter $^{3}$ and the International Bill of Human Rights, ${ }^{4}$ and informed by provisions

1. United Nations General Assembly Resolution A/RES/70/1, Transforming Our World: the 2030 Agenda for Sustainable Development (Sep. 25, 2015).

2. Id.

3. U.N. CHARTER.

4. The International Bill of Human Rights:

A. Universal Declaration of Human Rights (UDHR), G.A. Res. 217 (III), U.N. GAOR, 3d Sess., U.N. Doc. A/810 at 71 (1948);

B. International Covenant on Civil and Political Rights (ICCPR), GA Res. 2200A (XXI), 21 U.N. GAOR Supp. 16, at 52, U.N. Doc. A/6316 (1966), 999 U.N.T.S. 171, 6 ILM 368 (1967);

C. International Covenant on Economic, Social, and Cultural Rights (ICESCR), G.A. Res. 2200A (XXI), 21 U.N. GAOR Supp. 16, at 49, U.N. Doc. A/6316 (1966), 993 U.N.T.S. 3, 6 ILM 368 (1967). 
and principles of other major instruments and declarations;

(b) Examine and critically evaluate, provisions of the seventeen Sustainable Development Goals (SDGs)," stated in U.N. General Assembly Resolution A/RES/70/1, “Transforming Our World: the 2030 Agenda for Sustainable Development," adopted by the U.N. General Assembly on September 25, 2015;

(c) Suggest practical measures to protect, preserve, and enhance the realization of critically important human rights inherent in the framework of Sustainable Development, and, thereby, advance the goals of Sustainable Development.

\section{B. Background and Formative Events}

The modern environmental movement seems to have sensed, from its inception in the late 1960s, that human rights and preservation of the global environment are closely interrelated. ${ }^{6}$ This perspective was reflected in a statement issued by the 1972 Stockholm U.N. Conference on the Human Environment: "Both aspects of man's environment, the natural and the man-made, are essential to his well-being and to the enjoyment of basic human rights - even the rights to life itself.",

However, the developing recognition of the linkage between human rights and

5. United Nations General Assembly Resolution A/RES/70/1, supra, note 1.

6. John H. Knox, Human Rights, Environmental Protection, and the Sustainable Development Goals. 24Wash. Int'l L.J. 517, 519 (2015). Professor John H. Knox of Wake Forest University School of Law, North Carolina, USA, is United Nations Special Rapporteur on the issue of human rights obligations relating to the enjoyment of a safe, clean, healthy and sustainable environment.

7. U.N. Conference on the Human Environment, Declaration of the United Nations Conference on the Human Environment (Stockholm Declaration), at Chap. I, If 1,

U.N. Doc. A/CONF.48/14/Rev. 1 (1973), (June 16, 1972), 11 I.L.M. 1416. 
issues of preservation of the environment came too late for the specific rights involved to be incorporated in the major international human rights agreements. ${ }^{\mathbf{8}}$ The United Nations General Assembly had already adopted the Universal Declaration of Human Rights in 1948, and the International Covenant on Civil and Political Rights and the International Covenant on Economic, Social, and Cultural Rights in 1966.' Early efforts to embody the right to a healthy environment in a new global human rights instrument were unsuccessful. ${ }^{\mathbf{1 0}}$ Notably, in 1994, the principal United Nations human rights body, the Human Rights Commission, refused to adopt a proposed declaration linking human rights with the environment. ${ }^{11}$

Despite these setbacks, significant progress was achieved in subsequent years. The United Nations Conference on Sustainable Development, held in Rio de Janeiro, Brazil, June 20-22, 2012, declared that "every state has the responsibility 'to respect, protect, and promote human rights,' and that "democracy, good governance and the rule of law ... are essential for sustainable development" in each of its three dimensions: economic growth, social development, and environmental protection. ${ }^{\mathbf{1 2}}$

8. Knox, Human Rights, Environmental Protection, and the Sustainable Development Goals, supra note 6, at 519.

9. Universal Declaration of Human Rights (UDHR), (Dec. 10, 1948) GA res. 217A (III), UN GAOR, 3d Sess., UN Doc. A/810 at 71 (1948); International Covenant on Civil and Political Rights (ICCPR), GA res. 2200A (XXI), 21 UN GAOR Supp. (No. 16) at 52, UN Doc. A/6316 (1966), 999 UNTS 171, 6 ILM 368 (1967); International Covenant on Economic, Social, and Cultural Rights (ICESCR), GA res. 2200A (XXI), 21 UN GAOR Supp. (No. 16) at 49, UN Doc. A/6316 (1966), 993 UNTS 3, 6 ILM 368 (1967).

10. Knox, Human Rights, Environmental Protection, and the Sustainable Development Goals, supra note 6 , at 519.

11. Id.

12. Knox, Human Rights, Environmental Protection, and the Sustainable Development Goals, supra note 6, at 517 (citing United Nations Conference on Sustainable Development, Rio de Janeiro, Brazil, Jun. 20-22, 2012, The Future We Want, U.N. Doc. A/CONF. 216/L. 1, III 9, 10 (Jun. 19, 2012)). 
In March 2012, prior to the commencement of the Conference on Sustainable Development, the United Nations Human Rights Council appointed an Independent Expert, with a three-year mandate, to clarify human rights obligaations in regard to environmental protection, and to identify good practices in their use. ${ }^{13}$ The expert, Mr. John H. Knox, was specifically requested to "[t]ake into account the results of the 2012 United Nations Conference on Sustainable Development and contribute a human rights perspective to follow-up processes." ${ }^{\mathbf{1 4}}$ In the following year (2013), U.N. Secretary-General Ban Ki-Moon characterized an essential building block for a sustainable development agenda as a "far-reaching vision of the future firmly anchored in human rights and universally accepted values and principles." ${ }^{, 15}$

The report of the Independent Expert, Mr. John H. Knox, submitted to the U.N. Human Rights Council on March 11, 2014, indicated that State responsibilities, in regard to issues of the environment, include:

$$
\text { ... procedural obligations ... to assess environmental }
$$
impacts on human rights and to make environmental information public, to facilitate participation in environmental decision making, and to provide access to remedies for environmental harm. It also describe[d] States' substantive obligations to adopt legal and institutional frameworks that protect against environmental harm that interferes with the enjoyment of human rights, including harm caused by private actors. Finally, it outline[d]

13. Human Rights Council Res. 19/10, II 2, U.N. Doc. A/HRC/RES/19/10 (Mar. 22, 2012). The Independent Expert appointed by the U.N. Human Rights Council, was Professor John H. Knox of Wake Forest University School of Law, North Carolina, USA. Prof. Knox is United Nations Special Rapporteur on the issue of human rights obligations relating to the enjoyment of a safe, clean, healthy and sustainable environment.

14. Id. at $\mathbb{I} 2(\mathrm{~d})$.

15. U.N. Secretary-General, A Life of Dignity For All: Accelerating Progress Towards the Millennium Development Goals and Advancing the United Nations Development Agenda Beyond 2015: Report of the Secretary-General, IIII 74 - 75, U.N. Doc. A/68/202 (Jul. 26, 2013). 
obligations relating to the protection of members of groups in vulnerable situations, including women, children and indigenous peoples. $^{16}$

An important outcome of the U.N. Conference on Sustainable Development of 2012 was the adoption of two major United Nations General Assembly Resolutions: Resolution A/RES/66/288, “The Future We Want,” (July 27, 2012), and its directly lineal successor, Resolution A/RES/70/1, "Transforming Our World: the 2030 Agenda for Sustainable Development," (September 25, 2015). ${ }^{\mathbf{1 8}}$ Both Resolutions incorporated provisions for protection of the environment in the larger, more complex framework of "Sustainable Development," with its three dimensions of economic growth, social development, and environmental protection. ${ }^{19}$ The integration of provisions for economic growth, social development, and environmental protection into the multi-dimensioned construct, "Sustainable Development," seems to reflect the perspective that these components are interrelated, and that none of the three components can be realized independently of the others.

This study addresses a range of critically important issues of human rights, in relation to goals of Sustainable Development. Irrespective of the particular

16. John H. Knox, UN Special Rapporteur, Mapping Report - 2014, UNITED NATIONS MANDATE ON HUMAN RIGHTS AND THE ENVIRONMENT: http://srenvironment.org/mapping-report-2014-2/ (last visited Nov. 12, 2017).

17. United Nations General Assembly Resolution A/RES/66/288, The Future We Want (Jul. 27, 2012).

18. United Nations General Assembly Resolution A/RES/70/1, supra note 1.

19. United Nations General Assembly Resolution A/RES/66/288 (2012), supra note 17 , at II 6; United Nations General Assembly Resolution A/RES/70/1 (2015), supra note 1, at Preamble II 3. 
ultimate resolutions of these and related issues, the circumstances offer unparalleled opportunities for active collaboration among international organizations, national governments, and business entities, to design remedial measures in areas of common concern. These endeavors implicate the preservation and enhancement of human rights grounded in provisions and principles of the U.N. Charter ${ }^{20}$ and the International Bill of Human Rights, ${ }^{\mathbf{2 1}}$ and supported by provisions and principles of of other major instruments and declarations.

\section{Relevant Instruments, Declarations, \& Guidelines}

The primary international agreements, declarations, and guidelines relevant to issues of human rights and Sustainable Development, include the following:

1. United Nations General Assembly Resolution A/RES/66/288, "The Future We Want;"22

2. United Nations General Assembly Resolution A/RES/70/1, "Transforming Our World: The 2030 Agenda for Sustainable Development;",23

3. The Charter of the United Nations; ${ }^{20}$

4. The International Bill of Human Rights; ${ }^{21}$

5. International Labour Organization (ILO) Convention No. 111, on the subject of discrimination in employment and occupation, ${ }^{\mathbf{2 4}}$

20. U.N. CHARTER.

21. The International Bill of Human Rights, supra note 4.

22. United Nations General Assembly Resolution A/RES/66/288 (2012), supra note 17.

23. United Nations General Assembly Resolution A/RES/70/1 (2015), supra note 1.

24. Discrimination (Employment and Occupation) Convention, International Labour Organization (ILO) Convention No. 111 (Jun. 25, 1958, Jun. 15, 1960), 362 UNTS 31. 
6. International Convention on the Elimination of All Forms of Racial Discrimination (CERD), ${ }^{25}$

7. United Nations Convention relating to the Status of Refugees, ${ }^{\mathbf{2 6}}$

8. Protocol relating to the Status of Refugees, ${ }^{27}$

7. Convention on the Elimination of All Forms of Discrimination Against Women (CEDAW), ${ }^{\mathbf{2 8}}$

8. Convention on the Rights of the Child (CRC), ${ }^{29}$

9. Convention concerning Indigenous and Tribal Peoples in Independent Countries (ILO No. 169); $;^{30}$

10. U.N. Declaration on the Rights of Indigenous Peoples (UNDRIP), ${ }^{\mathbf{3 1}}$

11. Guiding Principles on Business and Human Rights: Implementing the United Nations "Protect, Respect and Remedy" Framework;

12. United Nations Global Compact Guide to Corporate Sustainability; ${ }^{\mathbf{3 3}}$

25. International Convention on the Elimination of All Forms of Racial Discrimination (CERD), (Dec. 21, 1965, Jan. 4, 1969), G.A. res. 2106 (XX), Annex, 20 U.N. GAOR Supp. (No. 14) at 47, U.N. Doc. A/6014, 660 UNTS 195 (1966).

26. Convention relating to the Status of Refugees, (Jul. 28, 1951, Apr. 22, 1954), 189 UNTS 150.

27. Protocol relating to the Status of Refugees, (Jan. 31, 1967, Oct. 4, 1967), 606 UNTS 267.

28. Convention on the Elimination of All Forms of Discrimination against Women (CEDAW), (Dec. 18, 1979, Sep. 3, 1981), 34 UN GAOR Supp. (No. 46) at 193, UN Doc. A/34/46; 1249 UNTS 13; 19 ILM 33 (1980)

29. Convention on the Rights of the Child (CRC), (Nov. 20, 1989, Sep. 2, 1990), GA res. 44/25, annex, 44 UN GAOR Supp. (No. 49) at 167, U.N. Doc. A/44/49 (1989); 1577 UNTS 3; 28 ILM 1456 (1989).

30. Convention concerning Indigenous and Tribal Peoples in Independent Countries (ILO No. 169), (Jun. 27, 1989, Sep. 5, 1991), 72 ILO Official Bull. 59; 28 ILM 1382 (1989).

31. United Nations Declaration on the Rights of Indigenous Peoples (UNDRIP), A/RES/61/295, (Sep. 13, 2007).

32. Guiding Principles on Business and Human Rights: Implementing the United Nations “ Protect, Respect and Remedy' Framework, A/HRC/17/31 (2011).

33. United Nations Global Compact Guide to Corporate Sustainability (2014). 
13. Convention on Biological Diversity; ${ }^{\mathbf{3 4}}$

14. Cartagena Protocol on Biosafety to the Convention on Biological Diversity; ${ }^{35}$

15. Nagoya Protocol on Access to Genetic Resources and the Fair and Equitable Sharing of Benefits Arising from their Utilization to the Convention on Biological Diversity; ${ }^{36}$

16. United Nations Convention on the Law of the Sea; ${ }^{37}$

17. United Nations Framework Convention on Climate Change (UNFCC); ${ }^{\mathbf{3 8}}$

18. Kyoto Protocol to the United Nations Framework Convention on Climate Change; ${ }^{41}$

19. Paris Agreement to the United Nations Framework Convention on Climate Change ${ }^{42}$

20. Convention for the Protection of the Ozone Layer (Vienna Convention); ${ }^{\mathbf{4 3}}$

21. Montreal Protocol on Substances that Deplete the Ozone Layer. ${ }^{44}$

36. Convention on Biological Diversity, (Jun. 5, 1992, Dec. 29, 1993), 1760 UNTS 79; 31 ILM 818 (1992).

37. Cartagena Protocol on Biosafety to the Convention on Biological Diversity, (Jan. 29, 2000, Sep. 11, 2003), 2226 U.N.T.S. 208; 39 ILM 1027 (2000); UN Doc. UNEP/CBD/ ExCOP/1/3, at 42 (2000).

38. Nagoya Protocol on Access to Genetic Resources and the Fair and Equitable Sharing of Benefits Arising from their Utilization to the Convention on Biological Diversity, (Oct. 29, 2010, Oct. 12, 2014), No U.N.T.S volume number determined for this record.

39. United Nations Convention on the Law of the Sea, 1833 UNTS 3; 21 ILM 1261(1982).

40. United Nations Framework Convention on Climate Change (UNFCCC), (May 9, 1992, Mar. 21, 1994), 1771 UNTS 107; S. Treaty Doc No. 102-38; U.N. Doc. A/AC.237/18 (Part II)/Add.1; 31 ILM 849 (1992).

41. Kyoto Protocol to the United Nations Framework Convention on Climate Change, UN Doc. FCCC/CP/1997/7/Add.1, Dec. 10, 1997; 37 ILM 22 (1998).

42. Paris Agreement to the United Nations Framework Convention on Climate Change, UN Doc FCCC/CP/2015/L.9/Rev.1, Dec. 12, 2015 (2016).

43. Convention for the Protection of the Ozone Layer (Vienna Convention), TIAS No. 11,097; 1513 UNTS 323; 26 ILM 1529 (1987).

44. Montreal Protocol on Substances that Deplete the Ozone Layer (Montreal Protocol), (Sep. 16, 1987, Jan. 1, 1989), 1522 UNTS 3; 26 ILM 1550 (1987). 


\section{The Concept of "Sustainability"}

The discipline of sustainability is based primarily on principles stated "The Brundtland Commission"). ${ }^{45}$ In a report notable for its breadth of vision, the Commission observed that the development path required was “... one that sustained human progress not just in a few places for a few years, but for the entire planet into the distant future. ${ }^{, 46}$

In essence, the term, "sustainability," is applicable to systems that are able to persist, or function, in steady states, over extended periods of time ${ }^{47}$ The Oxford English Dictionary provides the following definition of the ecological meaning of the word, "sustainability": "Of, relating to, or designating forms of human economic activity and culture that do not lead to environmental degradation, especially avoiding the long-term depletion of natural resources." 48 The core concept of "system," is fundamental to that of sustainability, and denotes a coherently organized set of interrelated elements, with an identity apart from, and greater than the sum of its omponents. ${ }^{49}$ The Earth is itself a system composed of numerous other contained and interrelated systems. ${ }^{\mathbf{5 0}}$ The biophysical world is an immensely complex, three-

45. REPORT OF THE WORLD COMMISSION ON ENVIRONMENT AND DEVELOPMENT: OUR COMMON FUTURE, http://www.un-documents.net/our-common-future.pdf (last visited Feb. 8, 2017).

46. Id. at Chap. I, § 1, II 10 .

47. Margaret Robertson, Sustainability: Principles and Practice 3 (2014). Ms. Margaret Robertson is Coordinator of the Sustainability Coordinator degree program at Lane Community College in Eugene, Oregon, USA, and a Sustain ability Fellow in the Higher Education Association Sustainability Consortium.

48. ROBERTSON, supra note 47, at 4, (citing Simpson, J. and Weiner, E., OXFORD ENGLISH DictionARY, New York: Oxford University Press, 2009).

49. ROBERTSON, supra note 47 , at 4, (citing Meadows, Donella, ThINKING IN SYSTEMs: A PRIMER, White River, VT: Chelsea Green 2008).

50 ROBERTSON, supra note 47 , at 4. 
dimensional network of inter-conneted systems. ${ }^{\mathbf{5 1}}$ Within the soil of the Earth there are billions of living organisms, all connected through links of ecosystems, to each other and to the soil particles and roots that make up their world. ${ }^{\mathbf{5 2}}$

A remarkable aspect of the natural systems of the Earth is the absence of waste in their integrated operations. ${ }^{\mathbf{5 3}}$ Energy and materials are successively cycled and recycled, with the waste products from one organism or system becoming inputs or nutrients for another. ${ }^{\mathbf{5 4}}$ It is noteworthy also that materials and processes are not static. ${ }^{\mathbf{5 5}}$ Energy and chemicals are constantly exchanged, and the system in its totality is in a state of dynamic equilibrium. ${ }^{\mathbf{5 6}}$

These living systems are finite, and principles of sustainability proscribe practices that will exhaust their capacities of renewal and regeneration. ${ }^{57}$ It is to be noted that being "green," or environmentally responsible, is not the same as adopting "sustainable" practices. $^{\mathbf{5 8}}$ While actions such as recycling and using less toxic products are important, a focus limited to being 'less bad' by depleting irreplaceable capital more slowly or by poisoning life on Earth more gradually is not coterminous with practices of sustainability. ${ }^{\mathbf{5 9}}$

$\begin{array}{ll}\text { 51. } & I d . \\ 52 . & I d . \\ 53 . & I d . \\ 54 . & \text { ROBERTSON, supra note } 47, \text { at } 4 . \\ 55 . & I d . \\ 56 . & I d . \\ 57 . & \text { ROBERTSON, supra note } 47, \text { at } 5 . \\ 58 . & I d . \\ 59 . & \text { ROBERTSON, supra } \text { note } 47, \text { at } 5 .\end{array}$




\section{(1) The Three Pillars of "Sustainability"}

Three primary factors (or pillars) of "sustainability" have been identified:

the "environment," "economics," and "equity."60 In recent decades, scientists and planners have begun to realize that the Earth has many interconnected issues, including those of poverty, health, overpopulation, resource depletion, food and water scarcity, political instability, and destruction of essential life support systems. ${ }^{61}$ An awareness has developed that these problems cannot be separated and dealt with in isolation from each other. ${ }^{62}$ The concept of "sustainability" recognizes the need "to foster communities that are healthy, safe, and secure, with economic opportunity for everyone while keeping Earth's life support system in good shape.,63

The first of the pillars of sustainability represents the environment (or ecology), and refers to preservation nd restoration to health of ecosystems that purify air and water, pollinate crops, provide food, recycle waste, and circulate atmospheric gases, chemical elements, and energy. ${ }^{64}$ The maintenance of sustainable planetary conditions requires a comprehensive understanding of the inner workings of these systems, and the ability to live within their limits. ${ }^{65}$

60. Id.

61. Id.

62. Id.

63. ROBERTSON, supra note 47, at 5, (citing Cortese, Anthony, "Foreword," in Holley Henderson, Becoming a Green Professional: A Guide to Careers in Sustainable Architecture, Development and More, at xi-xiii, New York: John Wiley, 2012).

64. ROBERTSON, supra note 47, at 5 .

65. Id. 
The second of the pillars of sustainability is based on an economics designed to ensure that material resources are distributed fairly, with each individual able to meet his or her own basic human needs. ${ }^{\mathbf{6}}$ It has been recognized that unlimited economic growth is not sustainable, although progressive enhancement of the quality of life is viewed as an attainable objective. ${ }^{67}$ Economic growth that exhausts natural resources, pollutes the soil, air, and water, and depletes ecosystem services will eventually lead to a decline in the quality of life. ${ }^{\mathbf{6 8}}$

The third pillar of sustainability represents equity, and has alternatively been designated "social equity" or "equality.",69 Equity includes freedom from unhealthy living conditions, and equal access to food, water, employment, education, and healthcare; with opportunities for all people - not just a privileged few - to grow and flourish in their own ways. ${ }^{\mathbf{7 0}}$

\section{(2) The Current Situation}

Sustainability scientists have noted the current adverse state of the planet.",71 A variety of factors indicate that the situation is "critical and getting worse."72 The world's human population was estimated in the year 2015 to be about 7.2 billion, and growing at an annual rate of about 75 million. ${ }^{73}$ This vast, and growing, assemblage

66. Id.

67. ROBERTSON, supra note 47, at 5-6,

(citing Daly, Herman E. and Joshua Farley, Ecological Economics: Principles and Applications, at 12 (2003)).

68. ROBERTSON, supra note 47 , at 6.

69. ROBERTSON, supra note 47, at 6, (citing Edwards, Andres R. The Sustainability Revolution Portrait of a Paradigm Shift, at 23 (2005)).

70. ROBERTSON, supra note 47, at 6.

71. ROBERTSON, supra note 47 , at 6.

72. Id.

73. JefFrey D. SACHS, The Age of Sustainable Development 1 (2015). Professor Jeffrey D. Sachs is Director of the Earth Institute at Columbia University, nd Senior Advisor to the Secretary-General of the United Nations. 
of human beings is constantly seeking economic advancement, and is doing so in a global economy that is increasingly interconnected through the varied channels of trade, finance, technologies, production flows, migration, and social networks. ${ }^{\mathbf{7 4}}$ In the modern age, billions of people enjoy longevity of life and standards of health inconceivable in previous generations, and yet, at least 1 billion people live in such abject poverty that they struggle for mere survival on a daily basis. ${ }^{75}$ The massive world economy is apparently creating an environmental crisis that threatens the lives and well-being of billions of people, and the survival of millions of other species on the planet. ${ }^{\mathbf{7 6}}$ There are indications that the activities of humanity are changing the Earth's climate, the availability of fresh air and water, the chemistry of the oceans, and the habitats of other species. $^{77}$

It is estimated that "these impacts are now so large that Earth itself is undergoing unmistakable changes in the functioning of key processes - such as the cycles of water, nitrogen, and carbon - upon which life depends.",78

Our planet has seen five previous mass extinctions in its 4.5 billIon year history. We have now entered the sixth great extinction ${ }^{\mathbf{7 9}}$ and are seeing species disappearing at a quickening rate, with a quarter

\section{$-$}

74. II. at 2 .

75. Id.

76. SACHS, supra note 73 , at 2.

77. Id.

78. Id.

79. ROBERTSON, supra note 47 , at 6 , (citing Primack, Richard B. A Primer of Conservation Biology, at 125 (4th ed. Sunderland, MA: Sinauer Associates (2008)). 
Notwithstanding prevailing concerns that the Earth's system is at the verge. ${ }^{\mathbf{8 0}}$ of a "planetary tipping point," the inherent logic of the discipline of sustainability points to important possibilities of restoration, renewal and regeneration. ${ }^{\mathbf{8 1}}$ Almost all the components needed to shape the new world already exist. ${ }^{\mathbf{8 2}}$ The changes needed will require focused, collaborative efforts, but can mean new business opportunities improved quality of life, and enhanced surroundings. ${ }^{\mathbf{8 3}}$

\section{E. Evolution of the Meaning of the Term, "Development"}

Recent decades have witnessed a marked process of evolution in the significance attributed to the term, "development." ${ }^{\mathbf{8 4}}$ Whereas the concept of development was formerly equated almost exclusively with economic growth, it is now understood to be linked with human development. ${ }^{\mathbf{8 5}}$ In its first annual "Human Development Report,",86 issued in 1990, the United Nations Development Program (“UNDP”) introduced the Human Development Index ("HDI"), an index which estimates development, not by income alone, but by indicators reflecting "life expectancy, literacy and command over

80. ROBERTSON, supra note 47, at 6, (citing IUCN (International Union for Conservation of Nature Species Extinction, The Facts (2007) Species Extinction -The Facts, THE IUCN RED LIST OF THREATENED SPECIES, https://cmsdata.iucn.org/downloads/species_extinction_05_2007.pdf (last visited Nov. 28, 2017)).

81. ROBERTSON, supra note 47 , at 6.

82. ROBERTSON, supra note 47 , at 7.

83. Id.

84. Ved P. Nanda, The Journey from the Millennium Development Goals to the Sustainable Development Goals, 44 Denv. J. Int'l L. \& Pol'y 389389 (2015-2016). Professor Ved P. Nanda of the University of Denver, is Founding Director of the International Legal Studies Program, and Director of the Ved Nanda Center for International and Comparative Law, University of Denver Sturm College of Law.

85. Id.

86. Id. 
a decent standard of living." ${ }^{87}$

In his foreword to the report, UNDP Administrator William H. Draper III, stated:

[W]e are rediscovering the essential truth that people must be at the center of all development. The purpose of development is to offer people more options. One of their options is access to income - not as an end in itself but as a means to acquiring human well-being. But there are other options as well, including long life, knowledge, political freedom, personal security, community participation and guaranteed human rights. People cannot be reduced to a single dimension as economic creatures. What makes them and the study of the development process fascinating is the entire spectrum through which human capabilities are expanded and utilized. ${ }^{\mathbf{8 8}}$

Subsequently, a declaration was adopted by heads of State and Government at the U.N. Headquarters, the "United Nations Millennium Declaration" of September 2000, which included human development goals with specific targets and a timeframe to measure progress. ${ }^{89}$

The commitment of world leaders to reducing prevalent conditions of extreme poverty by creating a new global partnership incorporating a series of time-bound targets for the years 2000-2015, became known as the Millennium Development Goals ("MDGs"). 90 Goal 7 of the MDGs sought to "ensure environmental sustainability," and Goal 8, to "develop a global partnership for development."91 A point on which the MDGs have been criticized, and which will be addressed in Part III of this study,

87. Id.at 1 .

88. Id.at iii.

89. United Nations General Assembly Resolution A/RES/55/2, United Nations Millennium Declaration (Sep. 18, 2000).

90. Id.

91. Millennium Development Goals, United NATIONs DeVELOPMENT PROGRAM (UNDP). 
derives from a perception of their "lack of a human rights focus." ${ }^{\text {92 }}$ Upon the expiration of the MDGs, at the end of 2015, the U.N. General Assembly adopted their successor, the Sustainable Development Goals ("SDGs"), in September 2015. ${ }^{\mathbf{9 3}}$

The material that follows will trace the evolutionary history of processes that culminated in the formulation of the complex modern framework of "Sustainable Development," with its interrelated dimensions of economic growth, social development, and environmental protection.

\section{F. A Brief History of Environmental and Related Initiatives}

In 1972, the United Nations organized the first global environment summit, the "UN Conference on the Human Environment," in Stockholm, Sweden. ${ }^{94}$ A pronouncement of the Conference reflected the evolving understanding that human rights and environmental protection are closely linked: "Both aspects of man's environment, the natural and the man-made, are essential to his well-being and to the enjoyment of basic human rights - even the right to life itself."95 The Conference established the United Nations Environment Programme (UNEP). ${ }^{\mathbf{9 6}}$

92. Nanda, The Journey from the Millennium Development Goals to the Sustainable Development Goals, supra note 82, at 393.

93. United Nations General Assembly Resolution A/RES/70/1 (2015), supra note 1.

94. U.N. Conference on the Human Environment, Declaration of the United Nations Conference on the Human Environment (Stockholm Declaration), U.N. Doc. A/CONF.48 / 14/Rev. 1 at Chap. I, II 1 (June 16, 1972), 11 I.L.M. 1416.

95. Id.

96. About UN Environment, UN, http://web.unep.org/about/who-we-are/overview (last visited Feb. 8, 2017). 
In 1983, the United Nations. chartered the "World Commission on Environment and Development" (WCED) under the leadership of Gro Harlem Brundtland, former Prime Minister of Norway. ${ }^{97}$ The WCED was tasked with developing shared definitions and goals, proposing long-term strategies for sustainable development, and recommending ways to address environmental and economic concerns through international cooperation. $^{98}$ The Commission issued a report in 1987, Our Common Future, which described sustainable development as:" ... development that meets the needs of the present without compromising the ability of future generations to meet their own needs." ${ }^{.99}$

In 1983, the Environmental Protection Agency (EPA) and National Academy of Sciences of the United States published reports linking the phenoenon of global warming to the buildup of greenhouse gases in the Earth's atmosphere. ${ }^{\mathbf{1 0 0}}$ In response to these findings, in 1988, the United Nations Environment [Program] (UNEP), in association with the World Meteorological Organization, founded the Intergovernmental Panel on Climate Change (IPCC). ${ }^{\mathbf{1 0 1}}$ The IPCC publishes peer-reviewed scientific research reports generally regarded as authoritative sources by governments and international organizations. ${ }^{102}$

97. ROBERTSON, supra note 47 , at 17.

98. Id.

99. REPORT OF THE WORLD COMMISSION ON ENVIRONMENT AND DEVELOPMENT: OUR COMMON FUTURE, http://www.un-documents.net/our-common-future.pdf (last visited Feb. 8, 2017). (citing G. TYLER Miller, JR. \& SCOTT E. SPOOLMAN, LiVING IN THE ENVIRONMENT: CONCEPTS, CONNECTIONS, AND SOLUTIONS S37 (Belmont, CA: Brooks/Cole 16th ed. 2009)).

100. ROBERTSON, supra note 47, at 17.

101. ROBERTSON, supra note 47, at 17-18.

102. ROBERTSON, supra note 47 , at 18 , citing DaVID E. Blockstein \& Leo Wiegman, The Climate Solutions CONSENSUS: What We KNOW AND WhAT TO DO ABOUT IT 9 (2010). 
Chlorofluorocarbons (CFCs) were introduced industrially as a refrigerant agent in the 1930s, to replace toxic ammonia, methyl chloride, and sulfur dioxide. ${ }^{\mathbf{1 0 3}}$ In 1976, the U.S. National Academy of Sciences reported that CFCs were damaging the ozone layer that shields the earth from excessive ultraviolet rays from the sun. ${ }^{\mathbf{1 0 4}}$ In 1985, in response to the Academy's report, 20 nations signed "The Vienna Convention for the Protection of the Ozone Layer."105

In the same year (1985), significant thinning of the ozone layer above Antarctica was discovered. ${ }^{\mathbf{1 0 6}}$ In 1987, forty three nations, including the United States, signed "The Montreal Protocol," in an agreement to phase out the use of CFCs, and to terminate their production by $1996 .^{107}$ The number of nations signatory to subsequent revisions of the Montreal Protocol, increased to $196 .^{\mathbf{1 0 8}}$ Based on projections from observed rates of recovery, scientists have predicted restoration of the ozone layer by $2050 .{ }^{109}$

In 1992, the U.N. arranged the "United Nations Conference on Environment and Development," known as the "Earth Summit," in Rio de Janeiro, Brazil. ${ }^{110}$ At the Earth Summit, delegates from 180 nations agreed to a set of 27 principles, embodied in the "Rio Declaration on Environment and Development."111 The Conference adopted "Agenda 21," which was described as a "comprehensive blueprint for a global

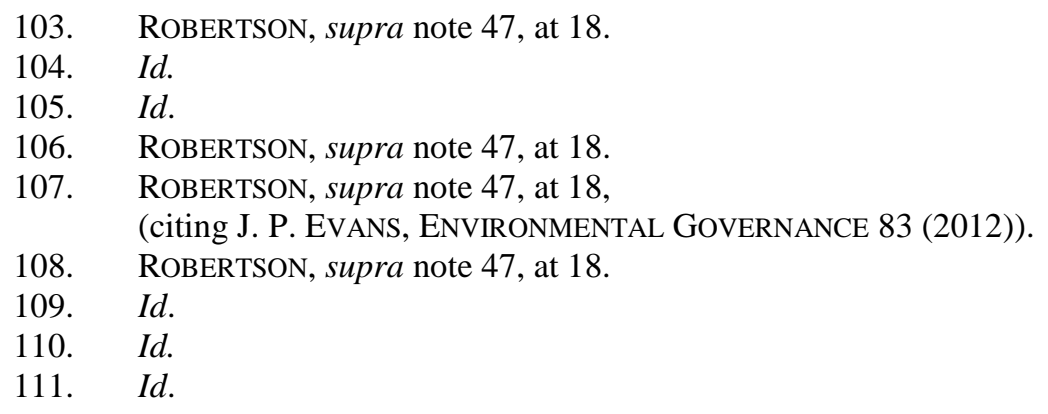


partnership [that] strives to reconcile the twin requirements of a high quality environment and a healthy economy for all people of the world."112 Further, the Conference enacted the following instruments: (a) "The UN Convention on Biological Diversity,",113 a legally binding international treaty, and (b) "The UN Framework Convention on Climate Change (UNFCCC), "114 a non-binding treaty, that led subsequently to "The Kyoto Protocol to the UNFCCC"115 and "The Paris Agreement to the UNFCCC., 116

Following the Earth Summit of 1992, the U.N. General Assembly held, in 1997, a special conference (designated "Earth Summit+5") to assess progress in implementation of the goals of Agenda 21. ${ }^{117}$ Reports by, delegates reaffirmed their commitment to the goals of Agenda 21, and developed a new set of goals termed “The Millennium Goals."119 Despite these endeavors, there were continuing reports of widening disparities between economic sectors, rising average global temperatures, and environmental deterioration. ${ }^{\mathbf{1 2 0}}$

112. United Nations Sustainable Development, Earth Summit Agenda 21: The U..N. Programme of Action from Rio. New York: UN Department of Public Information, 1992.

113. United Nations Convention on Biological Diversity, (1992), supra note 34.1

114. United Nations Framework Convention on Climate Change, (1992), supra note 38.

115. Kyoto Protocol to the United Nations Framework Convention on Climate Change (1998), supra note 39.

116. Paris Agreement to the United Nations Framework Convention on Climate Change, (2016), supra note 40.

117. ROBERTSON, supra note 47 , at 18.

118. Id.

119. Id.

120. Id. 
The "Millennium Ecosystem Assessment Reports," sponsored by the U.N., were released, starting in 2001. ${ }^{\mathbf{1 2 1}}$ These reports were compiled by over 1,360 scientists and other experts from around the world, and represented a joint effort to develop measurable indicators of the "Earth's Natural Capital.",122 The reports generally indicated that it was possible to reverse much of the degradation of the Earth's ecosystems over the next 50 years, but that "the changes in policy and practice required [were] substantial and not currently underway.",123

The United Nations Conference on Sustainable Development (designated “Rio+20”) was held in Rio de Janeiro, Brazil on June 20-22, 2012. ${ }^{\mathbf{1 2 4}}$ The Conference generated a comprehensive outcome document recognizing development as a human right, and recommending implementation, on an urgent basis, of "sustainable development" in its economic, social and environmental dimensions. ${ }^{\mathbf{1 2 5}}$ Resolution A/RES/66/288, ${ }^{\mathbf{1 2 6}}$ ("The Future We Want") embodying this recognition and recommendation among others, was adopted, without vote, by the U.N. General Assembly, on July 27, 2012. ${ }^{\mathbf{1 2 7}}$

121. ROBERTSON, supra note 47 , at 18.

122. ROBERTSON, supra note 47 , at 18 , (citing MillenNium Ecosystem AsSessment, Ecosystems AND Human Well-Being: SYNTHESIS (2005)).

123. Id.

124. United Nations Conference on Sustainable Development, Rio+20, SUSTAINABLE DEVELOPMENT KNOWLEDGE PLATFORM, https://sustainabledevelopment.un.org/rio20.html (last visited Mar. 11, 2017).

125. Id.

126. United Nations General Assembly Resolution 66/288 (2012), supra note 17.

127. Resolutions $66^{\text {th }}$ Session, GeNeral ASSEMBLy OF THE UNITED NATIONS, http://www.un.org/en/ga/66/resolutions.shtml (last visited Nov. 26, 2017). 
The fact that Resolution A/RES/66/288 was adopted by the U.N. General Assembly without a single opposing vote, ${ }^{\mathbf{1 2 8}}$ represents grounds for regarding the Resolution as having acquired "an authority which takes [it] out of the category of 'non-binding' pronouncements.",129

At the United Nations Conference on Sustainable Development (Rio+20), held in Rio de Janeiro in June 2012, Member States agreed to launch a process to develop a set of sustainable development goals (SDGs). ${ }^{\mathbf{1 3 0}}$ In accordance with that agreement, an Open Working Group (OWG) was established on January 22, 2013 by Decision 67/555 of the General Assembly (Document A/68/970). ${ }^{131}$ Among the stated goals of the OWG were actions to protect, restore, and promote sustainable use of terrestrial ecosystems, sustainably manage forests, combat desertification, halt and reverse land degradation, and halt biodiversity loss. ${ }^{\mathbf{1 3 2}}$

On August 12, 2014, the OWG proposed seventeen Sustainable Development Goals (SDGs) and 169 target outcomes, which were to be "further elaborated through indicators focused on measurable outcomes." ${ }^{\mathbf{1 3 3}}$ At a U.N. special summit in September 2015, world leaders formalized an ambitious plan

\footnotetext{
128. Resolutions $66^{\text {th }}$ Session, General AsSEmbly Of The United Nations, http://www.un.org/en/ga/66/resolutions.shtml (last visited Nov. 26, 2017).

129. See generally EgON SCHWElB, Human RightS AND THE INTERNATIONAL COMMUNITY 74

(1964). Distinguished Professor Egon Schwelb (1899-1979) of Yale University School of Law, was, at earlier stages of his career, Deputy Director of the United Nations Division of Human Rights (1947-1962), and Secretary of the Third Committee of the U.N. General Assembly.

130. United Nations General Assembly Official Document A/68/970, Report of the Open Working Group of the General Assembly on Sustainable Development Goals (2014).

131. Id.

132. Id.

133. U.N. General Assembly, Report of the Open Working Group of the General Assembly on Sustainable Development Goals, U.N. Doc. A/68/970 at § IV II 18 (Aug. 12, 2014).
} 
of action under the heading, "Transforming our world: the 2030 Agenda for Sustainable Development."134 The plan incorporated the OWG's seventeen goals and 169 targets to end poverty, reduce inequalities, and protect the environment. ${ }^{135}$ It issued on September 25, 2015, as U.N. General Assembly Resolution A/RES/70/1, and was adopted without a vote by the General Assembly. ${ }^{136}$ The fact that Resolution A/RES/70/1 was adopted by the U.N. General Assembly without a single opposing vote, ${ }^{\mathbf{1 3 7}}$ represents grounds for regarding the Resolution as having acquired "an authority which takes [it] out of the category of "non-binding' pronouncements."138

Part II of this study will review issues that impelled the launching of the global initiative of "Sustainable Development." Part II will survey symptoms, causes, and consequences of climate change, and examine issues in regard to water, the preservation of ecosystems and habitats, and approaches to problems of pollution and energy. It will examine the issues of poverty and inequality in relation to sustainable development, and survey prevalent contestations of anthropogenic causes of climate change.

Part III will survey the origins and evolution of the concept of human rights in international instruments and declarations, and present arguments that

134. United Nations General Assembly Resolution A/RES/70/1 (2015), supra note 1.

135. Id.

136. Resolutions $70^{\text {th }}$ Session, General Assembly Of The United NATIONS, http://www.un.org/en/ga/70/resolutions.shtml (last visited Nov. 26, 2017).

137. Id.

138. See generally SCHWELB, HUMAN RIGHTS AND THE INTERNATIONAL COMMUNITY (1964), supra note 129 , at 74. 
the framework of Sustainable Development encompasses legally cognizable human rights, grounded in provisions and principles of the U.N. Charter ${ }^{139}$ and the International Bill of Human Rights, ${ }^{\mathbf{1 4 0}}$ Further, Part III will present the positions of Amnesty International, Human Rights Watch, and Greenpeace on the symbiotic relationship between human rights and the ability to live and work in an environment and climate free of degradation. Finally, Part III will provide a critical evaluation of the Sustainable Development Goals of 2015, and concluding observations on material presented earlier.

Part IV will survey the political and technological aspects of possible measures of remediation; examine the need for collaborative approaches for developing remedial measures; and suggest a coordinating and mediating role for the U.N. Secretary-General in a worldwide initiative for sustainable development. Part V will provide concluding observations.

\section{G. Conclusion}

This study will examine issues of sustainable development. It will present arguments that the framework of sustainable development, in its economic, social, and environ mental dimensions, encompasses legally cognizable human rights, grounded in provisions and principles of the U.N. Charter ${ }^{141}$ and the International Bill of Human

139. U.N. CHARTER.

140 The International Bill of Human Rights:

A. Universal Declaration of Human Rights (1948);

B. International Covenant on Civil and Political Rights (1966);

C. International Covenant on Economic, Social, and Cultural Rights (1966)

supra note 3.

141. U.N. CHARTER. 
Human Rights, ${ }^{\mathbf{1 4 2}}$ and informed by provisions and principles of major international instruments and declarations. It will present a critical evaluation of provisions of the seventeen "Sustainable Development Goals (SDGs)," stated in U.N. General Assembly Resolution A/RES/70/1, "Transforming Our World: the 2030 Agenda for Sustainable Development, adopted by the Assembly on September $25,2015 .^{\mathbf{1 4 3}}$

The study will suggest that the protection of human rights inherent in Sustainable Development will require, at the outset, efforts to foster worldwide consensus on the question of whether observed environmental effects and climate changes have anthropogenic (human induced) origins. Further, agreement will need to be developed between developing and developed nations on questions of priorities to be accorded, as between efforts to promote economic growth and end conditions of poverty, and measures to preserve environmental resources. Difficult questions will have to be addressed in matters of technology transfer and financial assistance to developing nations, and on issues of international human migration that may be necessitated by situations of environmental disaster.

Finally, this study will suggest that implementation efforts will require collaborative international action to develop a strategy and plan for the carrying out of appropriate remedial measures. These endeavors will need to be

142. The International Bill of Human Rights:

A. Universal Declaration of Human Rights (1948);

B. International Covenant on Civil and Political Rights (1966);

C. International Covenant on Economic, Social, and Cultural Rights (1966) supra note 3.

143. United Nations General Assembly Resolution A/RES/70/1 (2015), supra note 1. 
coordinated by an entity possessed of breadth of vision, and qualities of neutrality, independence, and unimpeachable integrity. Further, the possibility must be considered that issues involved may threaten the maintenance of international peace and security. It will, accordingly, be suggested that an appropriate controlling and implementing agency could be led by the Secretary-General ${ }^{144}$ of the United Nations, supported by committees of experts in key functional areas.

144. See generally Article 99 of the U.N. CHARTER. 


\section{ISSUES OF SUSTAINABLE DEVELOPMENT}

\section{A. Introduction}

Part II of this study reviews issues that impelled the launching of the global initiative of "Sustainable Development." United Nations General Assembly Resolutions A/RES/66/288 and A/RES/70/1 incorporated provisions for protection of the environment in the larger, more complex framework of "Sustainable Development," with its three dimensions of economic growth, social development, and environmental protection. ${ }^{145}$ In view of the complex, multi-dimensioned framework of Sustainable Development envisioned in the two Resolutions, ${ }^{146}$ issues related to all three of the components of Sustainable Development - economic growth, social development, and environmental protection - will be examined in the material that follows.

\section{B. Symptoms, Causes, \& Consequences of Climate Change}

Section B of Part II presents phenomena and events attributed to changes of climate. The material in this section of the study has been drawn primarily from the Fifth Report of the Intergovernmental Panel on Climate Change (IPCC), and writings of distinguished Professors Jeffrey D. Sachs and Ann Powers. ${ }^{147}$

145. U.N. General Assembly Resolution A/RES/66/288 (2012), supra note 17, at II 6; U.N. General Assembly Resolution A/RES/70/1 (2015), supra note 1, at Preamble II 3.

146. United Nations General Assembly Resolution A/RES/66/288 (2012), supra note 17, United Nations General Assembly Resolution A/RES/70/1 (2015), supra note 1.

147. Core Writing Team, R.K. Pachauri and L.A. Meyer (eds.). IPCC, 2014: Climate Change 2014 Synthesis Report. Contribution of Working Groups I, II and III to the Fifth Assessment Report of the Intergovernmental Panel on Climate Change, IPCC, Geneva Sachs, The Age of Sustainable DeVelopment (2015), supra note 73; Ann Powers, Sea-Level Rise and Its Impact on Vulnerable States: Four Examples, 73 La. L. Rev. $151 \quad$ (Fall 2012); Ms. Powers is Associate Professor of Law Emerita at Pace University School of Law's Center for Environmental Law Studies, New York, U.S.A. 


\section{(1) Observed Climate Changes \& Their Causes}

The Fifth Report of the Intergovernmental Panel on Climate Change (IPCC), first published in 2015, observes that there is clear evidence of the impact of human activity on the Earth's climate system, noting that recent anthropogenic emissions of greenhouse gases have been the highest in history. ${ }^{\mathbf{1 4 8}}$ The report indicates that climate changes resulting from these emissions have had widespread impacts on human and natural systems. ${ }^{149}$

The IPCC's report observes that each of the last three decades has been successively warmer at the Earth's surface than any preceding decade since $1850 .^{150}$ The period from 1983 to 2012 was likely to have been the warmest 30-year period of the last 1,400 years in the Northern Hemisphere (stated to a medium degree of confidence). ${ }^{\mathbf{1 5 1}}$ The globally averaged combined land and ocean surface temperature data as calculated by a linear trend shows a warming of $0.85[0.65 \text { to } 1.06]^{\circ} \mathrm{C}$ over the period $1880-2012 .{ }^{152}$

The IPCC's report indicates that emissions of anthropogenic greenhouse gases have increased since the pre-industrial era, as a result, primarily, of economic and population growth, and are now at their highest levels in this period. ${ }^{\mathbf{1 5 3}}$ This phenomenon has led to atmospheric concentrations of carbon dioxide, methane and nitrous oxide that are unprecedented in at least the last

148. IPCC, 2014: Climate Change 2014: Synthesis Report, supra note 147, at 40.

149. Id.

150. Id.

151. Id.

152. IPCC, 2014: Climate Change 2014: Synthesis Report, supra note 147, at 40.

153. Id. at 44 . 
800,000 years. $^{154}$ The deleterious effects of these gases, together with those of other anthropogenic agents, have been detected throughout the climate system, and are considered to have been "extremely likely" to have been the dominant cause of the observed warming of the Earth since the mid-20th century. ${ }^{155}$

Professor Jeffrey D. Sachs, Director of the United Nations Sustainable Development Network, has written of the seeming rise in frequency and intensity of climate-related events in recent years. In late October 2012, during Superstorm Sandy, one of the most powerful storms to strike the Eastern Seaboard of the United States in modern times, police cars floated down the street in Manhattan, New York. ${ }^{156}$ The ocean level of the Eastern Seaboard, which was about onethird of a meter higher than it had been a century earlier, greatly exacerbated the effects of the flooding associated with the superstorm. ${ }^{157}$

Earlier in the year 2012, prior to the arrival of Superstorm Sandy, the United States suffered major crop losses as a result of a mega-drought and heat wave in the Midwest and western grain-growing regions. ${ }^{158}$ Drought conditions continued to affect parts of the U.S. West in succeeding years. ${ }^{159}$ On another continent, also during 2012, Beijing experienced massive flooding following especially heavy rains. ${ }^{\mathbf{1 6 0}}$ Indonesia experienced heavy flooding in 2014, while

154. IPCC, 2014: Climate Change 2014: Synthesis Report, supra note 147, at 40.

155. Id. at 47 .

156. Sachs, The Age Of Sustainable DeVelopment (2015), supra note 73, at 34-35.

157. Id. at 35 .

158. Id.

159. Id.

160. Id. . 
Australia was subjected to a devastating heat wave. ${ }^{161}$ Bangkok experienced major floods in October 2011, that inundated automobile parts suppliers, and disabled assembly lines in other parts of the world. ${ }^{\mathbf{1 6 2}}$

Mr. Sachs notes that the frequency and severity of climate-related threats worldwide have risen dramatically, and are likely to increase still further. ${ }^{163} \mathrm{He}$ quotes scientific views as indicating that human-induced changes are driving the Earth's physical and biological changes. ${ }^{164}$ A significant driver of these changes is the use by human societies worldwide of fossil fuels, such as coal, oil, and natural gas, the combustion of which causes carbon dioxide $\left(\mathrm{CO}_{2}\right)$ to be emitted into the atmosphere. ${ }^{\mathbf{1 6 5}}$ Rising levels of $\mathrm{CO}_{2}$ in the atmosphere are believed to be the main, though not exclusive, cause of climate change. ${ }^{\mathbf{1 6 6}}$

\section{(2) Future Climate Changes, Risk \& Impacts}

The IPCC cautions that continued emission of greenhouse gases will cause further warming and long-lasting changes in all components of the climate system, increasing the likelihood of severe, pervasive and irreversible impacts for people and ecosystems. ${ }^{\mathbf{1 6 7}}$ An attempt to limit climate change would require substantial and sustained reductions in greenhouse gas emissions, together with appropriate adaptation measures. ${ }^{168}$

161. SACHS, The AGE OF SUSTAINABlE DEVElOPMENT (2015), supra note 73, at 36.

162. Id. at 35-36.

163. SACHS, The AgE OF SUSTAINABLE DEVELOPMENT (2015), supra note 73, at 37.

164. Id. at 38 .

165. Id.

166. Id.

167. IPCC, 2014: Climate Change 2014: Synthesis Report, supra note 147, at 56.

168. Id. 
The IPCC's Report maintains that cumulative emissions of carbon dioxide will largely determine global mean surface warming by the late 21 st century and beyond. ${ }^{\mathbf{1 6 9}}$ The report indicates that projections of greenhouse gas emissions vary over a wide range, depending on both socio-economic development and climate policy. ${ }^{170}$

The IPCC's Report projects that surface temperature will rise over the $21 \mathrm{st}$ century under all assessed emission scenarios; that heat waves will occur more often and last longer; that extreme precipitation events will become more intense and frequent in many regions; and that oceans will continue to warm and acidify, and global mean sea level to rise. ${ }^{171}$

The IPCC notes that climate change will magnify existing risks and create new risks for natural and human systems; and that risks will be generally greater for disadvantaged people and communities. ${ }^{172}$ Increasing levels of warming increase the likelihood of severe, pervasive and irreversible impacts for people, species and ecosystems. ${ }^{173}$ Continued high emissions of greenhouse gases risk negative impacts for biodiversity, ecosystem services and economic development, and enlarge risks for human means of livelihood, subsistence and security. ${ }^{\mathbf{1 7 4}}$

The IPCC predicts that many aspects of climate change and associated impacts will continue for centuries, even if anthropogenic emissions of

169. IPCC, 2014: Climate Change 2014: Synthesis Report, supra note 147, at 56.

170. Id.

171. Id. at 58 .

172. IPCC, 2014: Climate Change 2014: Synthesis Report, supra note 147, at 64.

173. Id.

174. $I d$. 
greenhouse gases are stopped. It adds that the risks of abrupt or irreversible changes increase as the extent of the warming increases. ${ }^{175}$

\section{(3) Impacts of Sea-Level Rise in Four Vulnerable States}

\section{(a) Tuvalu}

Tuvalu, formerly Ellice Islands, is a small republic in the west-central Pacific Ocean, made up of nine small coral islands extending over a distance of some 420 miles $(676 \mathrm{~km}){ }^{\mathbf{1 7 6}}$ Jointly with what is now Kiribati (formerly the Gilbert Islands), Tuvalu formed the British Gilbert and Ellice Islands Colony before separately gaining its independence in $1978 .{ }^{177}$ The population of Tuvalu was determined in 2016 to be 11,200, and its GDP per capita in 2015 was estimated at $\$ 6,230 .^{178}$

The islands of Tuvalu are low-lying, most being 13 to 16 feet (4 to 5 meters) above sea level. ${ }^{179}$ There are no rivers in the islands. ${ }^{180}$ Rain catchment systems and wells are the sole sources of fresh water available to the populace. ${ }^{\mathbf{1 8 1}}$ The total land area of Tuvalu is 9.9 square miles (25.6 square kilometers). ${ }^{\mathbf{1 8 2}}$ Because the soils of the islands are porous, agriculture is limited. ${ }^{\mathbf{1 8 3}}$ Although pigs and chicken are raised, and seabirds, fish, and shellfish caught for food, the

175. IPCC, 2014: Climate Change 2014: Synthesis Report, supra note 147, at 73.

176. Barrie K. Macdonald, Tuvalu, ENCYClOPAEDIA BRITANNICA (last updated: Jun. 3, 2016), https://www.britannica.com/place/Tuvalu (last visited May 15, 2017)..

177. Id.

178. Id.

179. Barrie K. Macdonald, Tuvalu, EnCYClopaedia BRitanNiCA (last updated: Jun. 3, 2016), https://www.britannica.com/place/Tuvalu (last visited May 15, 2017).

180. Id.

181. Id

182. Id.

183. Id. 
islands increasingly depend on imported food. ${ }^{\mathbf{1 8 4}}$ Tuvalo's Exclusive Economic Zone (EEZ) under provisions of the United Nations Convention on the Law of the Sea (UNCLOS) has been estimated at 900,000 to 1.3 million square kilometers. ${ }^{\mathbf{1 8 5}}$

With its average elevation of only one meter above the sea, Tuvalu is one of the most vulnerable nations to a rise of sea-level. ${ }^{186}$ Increased storm activity and sea-level rise have made Tuvalu extremely susceptible to coastal erosion. ${ }^{\mathbf{1 8 7}}$ Coral reefs protect against coastal erosion; but temperature rise is likely to cause significant destruction of corals, and loss of the protection they provide. ${ }^{\mathbf{1 8 8}}$

It is likely, therefore, that the effects of sea-level rise, coastal erosion, and coral damage will be significant land-loss for Tuvalu, potentially shrinking its EEZ, and correspondingly diminishing its revenue from fishing activities which have contributed significantly to its national income. ${ }^{\mathbf{1 8 9}}$ Although Tuvalu derives a considerable part if its national revenues from the sale of offshore fishing licenses, its serious lack of means of protecting its substantial EEZ have resulted

184. Id.

185.. Powers, supra note 147 , at 155 (citing A.J. Tilling \& E. Fihaki, TuValu NAT'L Biodiversity StRategy \& ACTION PLAN, FOURTH NATIONAL REPORT TO THE CONVENTION ON BIOLOGICAL DiVERSiTY at 8 (2009), http://www.sprep.org/att/IRC/eCOPIES/Countries/Tuvalu/55.pdf (last visited May 16, 2017)).

186. Id. (citing A.J. TILLING \& E. FIHAKI at 7-8 (2009)).

187. Powers, supra note 147, at 155 (citing TUVALU'S NATIONAL ADAPTATION PROGRAMME OF ACTION at 32 (2007), http://www.sids2014.org/content/documents/162NAPA.pdf (last visited May 16, 2017)).

188. Powers, supra note 147, at 155-156 (citing TUVALU'S NATIONAL ADAPTATION PROGRAMME OF ACTION at 30 (2007), http://www.sids2014.org/content/documents/162NAPA.pdf (last visited May 16, 2017)).

189. Powers, supra note 147, at 156 (citing Fishery Country Profile: Tuvalu, FoOd \& AGric. ORG. OF THE UNITED NATIONS (Apr. 2002), http://www.fao.org/fi/oldsite/FCP/en/TUV/profile.htm (last visited May 17, 2017)). 
in widespread illegal and unreported fishing, and have made it difficult to manage the ten conservation areas it has established on eight of its islands. ${ }^{\mathbf{1 9 0}}$

\section{(b) Seychelles}

Seychelles, a republic in the western Indian Ocean, comprises one hundred and fifteen (115) islands, with lush tropical vegetation, beautiful beaches, and a wide variety of marine life. ${ }^{191}$ Seychelles has an exclusive economic zone (EEZ), under provisions of the United Nations Convention on the Law of the Sea (UNCLOS), of 1.4 million square kilometers. ${ }^{192}$ Because of its low-lying elevation and significant coastal development, the country is very susceptible to land loss as a result of sea-level rise. ${ }^{193}$ It has been estimated that a one-meter rise in sea levels would submerge many of Seychelles' islands, with a consequent loss of $70 \%$ of its land area. ${ }^{194}$

Seychelles' coral and mangrove ecosystems have been put at significant risk by the effects of climate change. ${ }^{195}$ These ecosystems provide Seychelles with natural protections against sea-level rise, offering strong protection against erosion and serving as both a breeding ground and a habitat for fish. ${ }^{196}$ Elevated ea temperatures near Seychelles have recently caused up to $95 \%$ mortality in some coral reefs, and further warming is likely to cause mass coral bleaching. ${ }^{197}$

190. Powers, supra note 145, at 156 (citing A.J. TILling \& E. FIHAKI at 10, 15 (2009)).

191. Donald Lee Sparks, Seychelles, ENCYClOPAEDIA BRITANNICA (last updated: Apr. 12, 2017) https://www.britannica.com/place/Seychelles (last visited May 17, 2017).

192. The Exclusive Economic Zone, THE GEOGRAPHY OF THE SEYCHELLES, http://www.seychelles.org/seychelles-info/geography-seychelles (last visited May 17, 2017).

193. Powers, supra note 145 , at 157.

194. Powers, supra note 145, at 157 (citing United Nations Env't Programme, Coastal Erosion and Climate Change in the Western Indian Ocean Islands).

195. Powers, supra note 145 , at 157.

196. Powers, supra note 145, at 157 (citing MINISTRY OF ENV'T \& TRANSP., REPUBLIC OF SEYCHELlES, INITIAL NATIONAL COMMUNICATION UNDER THE UNITED NATIONS Framework CONVENTION ON Climate CHANGE 1 (2000)).

197. Id. 
The economy of Seychelles is sustained primarily by tourism and fishing, which contribute over $40 \%$ of its GDP. ${ }^{198}$ In 1996 , tourism brought in over $\$ 100$ million to the republic (about $17 \%$ of its GDP), and employed $18 \%$ of its workforce. ${ }^{199}$ The artisanal fishing industry produces, about 4,500 tons of fish for domestic consumption and approximately 370 tons, worth over $\$ 2$ million, in exports. ${ }^{200}$ Fishing is a way of life in the Seychelles and is one of the most important sources of protein for the populace. ${ }^{201}$

\section{(c) Maldives}

The Republic of the Maldives is an independent island nation in the north-central Indian Ocean, consisting of a chain of about 1,200 small coral islands and sandbanks, some 200 of which are inhabited. ${ }^{202}$ All the islands are low-lying, none rising to more than 6 feet (1.8 meters) above sea level, with barrier reefs that afford protection from the destructive effects of monsoons. ${ }^{203}$ The atolls have sandy beaches, lagoons, and luxuriant vegetation. Fish abound in the waters of the islands, and sea turtles are caught for food and for their oil. ${ }^{204}$

198. Powers, supra note 147, at 158 (citing Seychelles, MANGROVES FOR THE FUTURE, http://www.mangrovesforthefuture.org/countries/members/seychelles (last visited May 17, 2017)).

199. Powers, supra note 147, at 158 (citing MINISTRY OF ENV'T \& TRANSP., REPUBLIC OF SEYCHELlES, INITIAL NATIONAL COMMUNICATION UNDER THE UNITED NATIONS FRAMEWORK CONVENTION ON ClimATE CHANGE 26 (2000)).

200. Powers, supra note 147, at 158 (citing MINISTRY OF ENV'T \& TRANSP., REPUBLIC OF SEYCHELlES, INITIAL NATIONAL COMMUNICATION UNDER THE UNITED NATIONS FRAMEWORK CONVENTION ON ClimATE CHANGE 96 (2000)).

201. Powers, supra note 147, at 158 (citing Ian Kawaley, Implications of the Exclusive Economic Zone and EEZ Management for Seychelles, a Small Midocean Commonwealth Territory, 29 OCEAN DEV. \& INT’L. L. 225, 234 (1998)).

202. The Editors of Encyclopædia Britannica, Maldives, ENCYCLOPAEDIA BRITANNICA (last updated: Jun. 6, 2016), https://www.britannica.com/place/Maldives (last visited May 16, 2017).

203. Id.

204. Id. 
The land area of the Maldives is approximately 115 square miles (298 square kilometers), and its population was determined to be 406,000 in $2016 .^{205}$ Its GDP per capita was estimated as $\$ 6,670$ in $2015 .^{206}$ Most of the population subsists on fishing, coconut collecting, and the growing of vegetables and melons, roots and tubers, and tropical fruits. ${ }^{207}$ Fishing, the traditional base of the economy, is the most important source of livelihood, and accounts for a major portion of export earnings. ${ }^{208}$

The Exclusive Economic Zone (EEZ) of the Maldives covers more than 859,000 square kilometers. ${ }^{209}$ Maldives has made a firm commitment to address the effects of climate change and was the first country to sign the Kyoto Protocol, calling for greenhouse gas reductions. ${ }^{\mathbf{2 1 0}}$ It has played an active role in calling attention to the plight of SIDS and has been instrumental in the TAlliance of 11 Island States' (AOSIS) initiative for climate change action. ${ }^{211}$ With over $80 \%$ of its land area less than one meter above sea level and its highest elevation no more than three meters, Maldives is another of the countries most vulnerable to sea-level rise. ${ }^{212}$ Due to significant beach erosion and its low-lying elevation, some

\footnotetext{
$205 I d$.

206. Id.

207. Id.

208. Id.

209. Powers, supra note 147, at 159 (citing MinISTRY OF HoME AFFAIRS, Hous. \& ENV'T, REPUBLIC OF MALDIVES, FIRST NATIONAL COMMUNICATION OF THE REPUBLIC OF Maldives to the United NATions Framework CONVEnTion on Climate Change 2 (2001)).

210. Powers, supra note 147, at 159 (citing MINISTRY OF HOME AFFAIRS, at 35)

211. Powers, supra note 147 , at 159.

212. Powers, supra note 147, at 159 (citing MinISTRY OF HOME AFFAIRS, at 5, 16).
} 
studies have estimated that with a one-meter rise in sea level, Maldives may cease to exist. $^{\mathbf{2 1 3}}$ Other studies have predicted that sea-level rise could cause Maldives' GDP to drop by almost $40 \%$ due to its impact on fishing and tourism. ${ }^{\mathbf{2 1 4}}$

\section{(d) Bangladesh}

Bangladesh, a nation of south-central Asia, is located in the delta of the Padma (Ganges) and Jamuna (Brahmaputra) rivers in the northeastern part of the Indian subcontinent. ${ }^{215}$ Aside from small higher areas of jungle-covered old alluvium rising to about 100 feet (30 meters) in the northwest and north-center, the territory of Bangladesh is a flat surface of recent alluvium, having a gentle slope and an elevation of generally less than 30 feet (9 meters) above sea level. ${ }^{\mathbf{2 1 6}}$

The land area of Bangladesh is 147,570 square kilometers (56,977 square miles), and its population was determined to be $161,261,000$ in $2016{ }^{{ }^{217}}$ Its GDP per capita was estimated at $\$ 1,190$ in $2015 .^{\mathbf{2 1 8}}$

The most significant feature of the landscape of Bangladesh consists of its rivers, which have shaped not only the physiography of the nation, but also the way of life of its people. ${ }^{219}$ Because about $80 \%$ of Bangladesh consists of coastal

213. Powers, supra note 145, at 159 (citing MINISTRY OF HOME AFFAIRS, at 5).

214. Powers, supra note 145, at 159 (citing INTERGOVERNMENTAL PANEL ON CLIMATE

Change, Climate Change 2007: Impacts, AdAPtations And Vulnerability, at 709 (

M.L. Parry et al. eds., 2007).

215. Syed S. Husain \& Hugh R. Tinker, EnCYClOPAEDIA BRITANNICA (last updated: Apr. 6, 2017), https://www.britannica.com/place/Bangladesh (last visited May 18, 2017).

216. Id.

217. Id.

218. Id.

219. Id. 
flood plains, sea-level rises could have potentially devastating consequences. ${ }^{\mathbf{2 2 0}}$ Approximately 35.1 million people live in the coastal zone. ${ }^{221}$ The World Bank has estimated that there will be a one-meter rise in sea level by 2100 , which would cause Bangladesh to lose over $17 \%$ of its territory. ${ }^{222}$

There are indications of vast natural gas fields in Bangladesh's deep water areas in the Bay of Bengal, as there are in surrounding areas of the sea controlled by India and Myanmar. ${ }^{223}$ These untapped reserves of offshore natural gas controlled by Bangladesh have been estimated at 18.1 trillion cubic feet, worth over $\$ 52$ billion. ${ }^{24}$

Bangladesh contains about $60 \%$ of the Sundarbans, an extended mangrove forest area covering approximately 407,313 hectares. ${ }^{225}$ The Sundarbans has been designated a UNESCO World Heritage site, and is the largest remaining reserve for the last few hundred wild Bengal tigers. ${ }^{\mathbf{2 2 6}}$ According to the IPCC, it is likely

220. Powers, supra note 147, at 161(citing MinistRy OF ENV'T \& FOREST GOV'T OF THE PEOPLE's RePUblic of BANGLADESh, NATIONAL ADAPTATION PROGRAMME OF ACTION 2 (2005), https://unfccc.int/resource/docs/napa/ban01.pdf (last visited May 22, 2017).

221. Powers, supra note 147, at 161 (citing Golan Mahabub Sarwar \& Mamunul H. Khan, Sea Level Rise: A Threat to the Coast of Bangladesh, 38 INTERNATIONALES ASIENFORUM $375,380(2007))$.

222. Id. at 376-378.11

223. Powers, supra note 147, at 161 (citing Badrul Imam, Op-Ed, Offshore: The New Gas Frontier of Bangladesh?, DAILY STAR (Oct. 16, 2009)).

224. Powers, supra note 147, at 161 (citing U.S. GEOLOGICAL SURVEY WORLD ENERGY ASSESSMENT TEAM, BANGLADESH: ASSESSMENT RESUlTS SUMMARY-ALLOCATED RESOURCES (2000), Bangladesh, USGS, https://certmapper.cr.usgs.gov/data/PubArchives/WEcont/regions/reg8/r8bang.pdf (last visited May 22, 2017).

225. Powers, supra note 147, at 161 (citing INT'L UNION FOR THE CONSERVATION OF NATURE \& Natural Res., Marine Protected Area NeEds in the South Asian SEAs Region VOL. 1: BANGLADESH at 5 (John C. Pernetta ed., 1993)).

226. Powers, supra note 147, at 161-162 (citing MINISTRY OF ENV'T \& FOREST GOV'T OF THE PEOPLE'S REPUBlic OF BANGLADESH, NATIONAL ADAPTATION PGM OF ACTION 2 (2005), https://unfccc.int/resource/docs/napa/ban01.pdf (last visited May 24, 2017). 
That a one-meter rise in sea level will destroy this fragile ecosystem. ${ }^{227}$ Since the Sundarbans serves the critically important function of protecting Bangladesh from coastal erosion, it is likely that its loss would lead to greater land-loss. ${ }^{228}$

(e) Summation of Sea-Rise Issues for the Four Vulnerable States

With rises of sea-level, the baselines from which most maritime zones are measured will change, with the result that the outer boundaries of such zones could also change, retreating landward. ${ }^{229}$ The effects of shifting baselines could lead to ltigation in the International Court of Justice (ICJ) and other tribunals, and in some cases, to armed confrontation, as occurred between Bangladesh and Myanmar over disputed deposits of oil and gas in the Bay of Bengal. ${ }^{\mathbf{2 3 0}}$

If a coastal state's baseline, and therefore, its maritime zones, were to shift Shift significantly landward, the change could have adverse consequences for the state's efforts to manage coastal waters and exploit its resources. ${ }^{231}$ If the shift were substantial, large expanses of waters formerly within the state's exclusive economic zone (EEZ), might be considered thereafter to have become part of the high seas, open to all other states. ${ }^{\mathbf{2 3 2}}$

Significant concerns of fairness are implicated in regard to state boundary demarcation. ${ }^{233}$ Most of the nations that are in danger of losing substantial

227. Powers, supra note 147, at 162 (citing Golan Mahabub Sarwar \& Mamunul H. Khan, Sea Level Rise: A Threat to the Coast of Bangladesh, 38 INTERNATIONALES ASIENFORUM 375, 384 (2007)).

228. Powers, supra note 147 (citing Sarwar \& Khan, Sea Level Rise: A Threat to the Coast of Bangladesh, 38 INTERNATIONALES ASIENFORUM 375, 385 (2007)).

229. Powers, supra note 147, at 162.

230. Id. at 163.

231. Powers, supra note 147, at 164.

232. Id.

233. Id. at 166 . 
amounts of territory if boundaries are redrawn to account for rises in sea-levels are "Small Island Developing States" (SIDS), and other developing coastal states. $^{\mathbf{2 3 4}}$ Such states contribute little to the global threat of climate change, and have little capacity for mitigation and adaptation to its dangers. ${ }^{\mathbf{2 3 5}}$ Yet they will bear a disproportionate share of the burden of climate change. ${ }^{\mathbf{2 3 6}}$

Indications are emerging that many developing states will face devastating consequences from the effects of climate change: ${ }^{237}$ The regime of moveable and shifting boundary baselines threatens to deplete some of the most valuable resources these nations possess. ${ }^{238}$ Shrunken EEZs will result in lower revenues from the fishing industries of Tuvalu, Seychelles, and Maldives. ${ }^{239}$ Nations such as Bangladesh may be unable to realize sufficient revenue from alternative resources to fund necessary adaptation infrastructure. ${ }^{\mathbf{2 4 0}}$

\section{(4) Pathways for Adaptation, Mitigation \& Sustainable Development}

The IPCC's Fifth Report indicates adaptation and mitigation as complementary strategies for reducing and managing the risks of climate change. ${ }^{241}$ The report estimates that substantial emission reductions over the next few decades can reduce climate risks in the 21 st century and beyond, increase prospects for effective adaptation, reduce the costs and challenges of mitigation in the longer term

234. Id.

235. Id. 236. Powers, supra note 147, at 166.

237. Id. at 167.

238. Id.

239. Id.

240. Id.

241. IPCC, 2014: Climate Change 2014: Synthesis Report, supra note 147, at 76. 
the longer term, and contribute to climate-resilient paths for sustainable development. $^{242}$

The IPCC observes that effective decision-making to limit climate change and its effects can be guided by a wide range of analytical approaches for evaluating expected risks and benefits, recognizing the importance of governance, ethical dimensions, equity, value judgments, economic assessments and diverse perceptions and responses to risk and uncertainty. ${ }^{243}$

The IPPC cautions that, without additional mitigation endeavors beyond those in place today, warming by the end of the 21 st century will lead to very high risk of severe, widespread and irreversible impacts globally (to a statistically high degree of confidence). ${ }^{\mathbf{2 4 4}}$ Tactics of mitigation will involve some level of risk because of adverse side effects, but these risks do not involve the same possibility of severe, widespread and irreversible impacts as could be caused by climate change. ${ }^{245}$ The IPPC observes that climate change is a threat to equitable and sustainable development; and that adaptation, mitigation and sustainable development are closely interrelated, with significant potential for synergies and trade-offs. ${ }^{\mathbf{2 4 6}}$

242. Id.

243. Id.

244. Id. at 77 .

245. Id.

246. IPCC, 2014: Climate Change 2014: Synthesis Report, supra note 147, at 90. 


\section{(5) Summation of Climate Change Issues}

The Fifth Report of the Intergovernmental Panel on Climate Change (IPCC), first published in 2015, states that there is clear evidence of the impact of human activity on the Earth's climate system, adding that recent anthropogenic emissions of greenhouse gases have been the highest in history. ${ }^{247}$

Mr. Jeffrey D. Sachs, Director of the U.N. Sustainable Developments Network notes that the frequency and severity of climate-related threats world-wide have risen dramatically, and a re likely to increase still further. ${ }^{248}$ He quotes scientific views as indicating that human-induced changes, caused in large part by the use of fossil fuels, are driving the Earth's physical and biological changes. ${ }^{249}$

Indications are emerging that many developing states will face devastating consequences from the effects of climate change. ${ }^{250}$ Shrunken Exclusive Economic Zones (EEZs) will result in lower revenues from the fishing industries of Tuvalu, Seychelles, and Maldives. ${ }^{\mathbf{2 5 1}}$ Nations such as Bangladesh may be unable to realize sufficient revenue from alternative resources to fund necessary adaptation infrastructure. ${ }^{252}$ Major concerns of fairness are implicated in regard to "Small Island Developing States" (SIDS), and other developing coastal states, since such states contribute little to the global threat of climate change, and yet will bear a disproportionate share of the burden of climate change. ${ }^{253}$

247. Id. at 40.

248. Sachs, The Age OF Sustainable DeVElopment (2015), supra note 73, at 37.

249. Id. at 34-35.

250. Powers, supra note 145, at 162.

251. Id. at 167.

252. Powers, supra note 145 , at 162.

253. Id. at 166. 
According to the IPCC, adaptation options exist in all sectors, but their context for implementation and potential to reduce climate-related risks, differs across sectors and regions. ${ }^{254}$ Mitigation options are available in every major sector, and can be more cost-effective if employed in an integrated approach that combines measures to reduce energy use and the greenhouse gas intensity of end-use sectors, to decarbonize energy supplies, reduce net emissions and enhance carbon sinks in land-based sectors. ${ }^{\mathbf{2 5 5}}$

The IPCC's report concludes with the observation that the effectiveness of adaptation and mitigation responses will depend on policies and measures employed across multiple planes of endeav or: international, regional, national and sub-national. ${ }^{256}$ Policies across all planes, supporting technology development, diffusion and transfer, as well as finance for responses to climate change, can complement and supplement the effectiveness of policies that directly promote adaptation and mitigation. ${ }^{\mathbf{2 5 7}}$

\section{E. Issues in Regard to Water}

Section E of Part II provides an evaluation of issues relating to the availability and uses of water. Further, it examines issues in regard to the remedial measures needed to ward off projected shortages of this essential commodity in future years.

254. IPCC, 2014: Climate Change 2014: Synthesis Report, supra note 145, at 95.

255. Id. at 98 .

256. Id. at 102.

257. Id. 
Paragraph 121 of U.N. General Assembly Resolution A/66/288, explicitly

recognizes the right to safe drinking water as a human right::

121. We reaffirm our commitments regarding the human right to safe drinking water and sanitation, to be progressively realized for our populations, with full respect for national sovereignty. We also highlight our commitment to the International Decade for Action, "Water for Life", 2005-2015. ${ }^{258}$

The issues of water are interrelated with those of climate change, ecosystems, the disposal of hazardous and toxic substances, and pollution, and should, therefore, be understood and dealt with in consonance with the principles and processes of sustainability.

\section{(1) The Sources and Uses of Water}

Although water covers more than 70 percent of the surface of the Earth, about 97.5 percent of its total volume is admixed with salt, and only the remaining 2.5 percent is available as freshwater. ${ }^{259}$ Of the total extent of the Earth's freshwater, only about 30.1 percent is ground water available for human use; the remainder is locked up in glaciers, snow, ice, and permafrost. ${ }^{260}$

Freshwater is a generally renewable resource, with a constant volume that moves through the hydrologic cycle, in which it is continually filtered and recycled. ${ }^{261}$ The primary issue in regard to the availability of water is that the human community has tended to extract it from the hydrologic cycle at a rate

258. United Nations General Assembly Resolution A/RES/66/288, supra note 17, II 121.

259 ROBERTSON, supra note 47, at 94.

260. MAGGIE BLACK \& JANNET KING, THE ATLAS OF WATER: MAPPING THE WorLD'S Most CRITICAL RESOURCE 21 (2d ed. 2009).

261. ROBERTSON, supra note 47 , at 95. 
that exceeds that at which it can be purified and replaced; and that human activities pollute a portion of the water. ${ }^{\mathbf{2 6 2}}$ The problems arising from the resulting imbalance in water supply and quality are compounded by the effects of global climate change. ${ }^{263}$

A combination of factors, including overpopulation, excessive consumption, and an uneven distribution of supply sources has led to a number of problems in relation to water, of which the most overt manifestation is that of apparent scarcity. ${ }^{\mathbf{2 6 4}}$ Other factors, which are less visible, but carry greater implications for the long-term, are those of water pollution, the depletion of underground aquifers, and damage to various ecosystems. ${ }^{\mathbf{2 6 5}}$ Water scarcity tends to trigger competition between human groups, and, particularly in developing nations, is a causal factor in prevailing conditions of poverty.$^{266}$

\section{(2) Depletion of Nonrenewable Sources of Water}

About a fifth of the water used in the United States is obtained from sub-surface deposits of groundwater known as aquifers. ${ }^{267}$ The world's largest known aquifer, the Ogallala Aquifer, is the primary source of water for agriculture in the Great Plains of the United States. ${ }^{\mathbf{2 6 8}}$ The water in the Ogallala Aquifer was deposited millions of years ago, and is estimated will require thousands of years to replenish. ${ }^{\mathbf{2 6 9}}$

\footnotetext{
262. Id.

263. Id.

264. Id.

265. Id.

266 BLACK \& KING, supra note 260, at 45.

267. ROBERTSON, supra note 47 , at 96.

268 ROBERTSON, supra note 47, at 97.

269 Id.
} 
An estimated 11 percent of the Ogallala's volume is calculated to have been lost since pumping from it began in the 1950s. ${ }^{270}$ The result has been that, in parts of Texas, Oklahoma, and Kansas, the water table has dropped more than 100 feet, and wells have gone dry on thousands of farms. ${ }^{271}$ The San Joaquin Valley in California, and the cities of Baton Rouge, Phoenix, Houston, and Mexico City are similarly faced with situations of land subsidence caused by excessive pumping of groundwater. $^{272}$

In developing nations, 90 percent of human waste is discarded in an untreated state into rivers. ${ }^{273}$ A lack of access to clean water is estimated to be the largest cause of disease, and resulting poverty, in many parts of the world. ${ }^{274}$ Further, rivers and lakes are increasingly polluted with fertilizer, pesticide residue, chemical wastes, and contaminants from industrial spills. ${ }^{275}$ Dams kill the living organisms that occupied the spaces of their reservoirs, and interrupt natural processes and damage ecosystems, both above and below their interrupt natural processes and damage ecosystems, both

270. ROBERTSON, supra note 47 , at 97 ,

(Citing Sandford, Robert William, Restoring the Flow: Confronting the World's Water

Woes, at 190 (Surrey: Rocky Mountain Books 2009)).

271. ROBERTSON, supra note 47 , at 97 , (Citing Brown, Lester R., Plan B 4.0: Mobilizing to Save Civilization, at 40 (New York: W. W. Norton \& Company, 2009)),

(Citing Cunningham, William P. and Mary Ann Cunningham, Environmental Science: A Global Concern, at 382 (11th ed. New York: McGraw-Hill, 2010)).

272. ROBERTSON, supra note 47, at 97 , (Citing Withgott, Jay and Scott Brennan, Essential Environment: The Science behind the Stories, at 263 (3rd ed. San Francisco: Pearson Benjamin Cummings, 2009)).

273 BLACK \& KING, supra note 260, at 14.

274. ROBERTSON, supra note 47, at 98.

275. ROBERTSON, supra note 47 , at 98. 
above and below their structures. ${ }^{276}$ Sediment deprivation in soil below dams results in habitat damage, loss of native fish species, and degradation of native stream-side ecosystems. ${ }^{277}$ Masses of decaying organic matter trapped in soil sediments, release methane, one of the greenhouse gases implicated in climate change. ${ }^{\mathbf{2 7 8}}$

\section{(4) Consumption of Water}

In the modern world, agriculture takes up about 70 percent of water use, industry about 20 percent, and domestic use about 10 percent. ${ }^{279}$ Systems of substantial state subsidization of water in parts of the world create artificially low prices for water in these areas, and eliminate the incentive to reduce usage. ${ }^{\mathbf{2 8 0}}$ Further, the benefiting consumers do not pay at all for the ecosystem services lost through environmental damage caused by dams, pollution, and groundwater depletion. $^{\mathbf{2 8 1}}$ High water prices in other regions create hardships for people who already live in conditions of poverty. ${ }^{282}$

\section{(5) Effects of Climate Change on Water Resources}

It is expected that significant effects of climate change will be manifested

276. Id.

277. ROBERTSON, supra note 47, at 99,

(Citing Riley, Ann L. Restoring Streams in Cities, at 355, Washington, DC: Island Press, 1998)).

278 BLACK \& KING, supra note 260, at 36.

279. Id. at 24.

280. ROBERTSON, supra note 47 , at 100 , (Citing Brown, Lester R., Plan B 4.0: Mobilizing to Save Civilization, at 174 (New York: W. W. Norton \& Company, 2009)).

281. ROBERTSON, supra note 47 , at 100.1

282. Id. 
in adverse effects on water resources. ${ }^{283}$ Some regions of the world will be subject to flooding, and others to droughts. ${ }^{\mathbf{2 8 4}}$ Water from glaciers is currently the main source of fresh water for one billion people. ${ }^{285}$ When such glaciers melt entirely, the rivers they supply will lose their primary sources of water. ${ }^{\mathbf{2 8 6}}$

\section{(6) Measures in Mitigation of Problems of Water Scarcity}

Sustainability professionals have suggested the following measures to ameliorate problems arising from global scarcities of water supplies:

1. Supply-side measures include the harvesting of rain-water, desalinization of seawater, and the protection of aquifers that supply drinking water. ${ }^{\mathbf{2 8 7}}$

2. On the demand-side, approaches could include the installation of low-flow plumbing fixtures, repairing leaks, recycling water from cooling systems, and implementing more efficient landscape irrigation practices. $^{\mathbf{2 8 8}}$

3. A suggested alternative to using high-quality water for secondary applications, is the use of "graywater" for such applications as washing vehicles, flushing toilets, and watering shrubbery. The term, "graywater," refers to wastewater from sinks, showers, clothes washers, and similar sources. ${ }^{289}$

283. ROBERTSON, supra note 47 , at 100.

284. Id.at 100-101.

285. BLACK \& KING, supra note 260, at 32.

286. Id.

287. ROBERTSON, supra note 47 , at 101.

288. Id.

289. Id. at 106. 


\section{(7) Summation of Issues in Regard to Water}

The issues of water are inextricably interrelated with those of climate change, ecosystems, the disposal of hazardous substances, and pollution. Accordingly, such issues should be examined and analyzed with the principles and processes of sustainability applicable in these other areas of concern.

Of the total extent of the Earth's water resources, only 2.5 percent is available as freshwater, of which, about 30.1 percent is groundwater, available for human use; the remainder is locked up in glaciers, snow, ice, and permafrost. $^{290}$ Factors such as contamination, excessive consumption, and uneven distribution of supply sources have led to situations of water scarcity, aquifer depletion, and damage to ecosystems. ${ }^{291}$ It is expected that among the significant effects of climate change will be adverse effects on the Earth's water resources. ${ }^{292}$

The following have been suggested as ameliorative measures to be undertaken in respect to issues of water availability and quality: (a) utilization of methods of conservation, such as the harvesting of rain-water, desalinization, of seawater, and the protection and preservation of aquifers and other important sources of water; (b) installation of devices to economize the various uses of water; and (c) use of water of lower quality for secondary applications that do not require water of high degrees of purity. ${ }^{293}$

290. See supra text accompanying notes 259-262.

291. See supra text accompanying notes 260-282.

292. See supra text accompanying notes 283-286.

293. See supra text accompanying notes 287-289. 


\section{F. Issues in Regard to Ecosystems \& Habitats}

Section F of Part II provides an account and evaluation of issues relating to the need for the preservation of the Earth's ecosystems and habitats. The issues of ecosystems and habitats are interrelated with those of environment, climate change, the availability and quality of water, the disposal of hazardous and toxic substances, and pollution, and should, therefore, be dealt with in consonance with the principles and processes of sustainability.

\section{(1) Ecosystems and Biodiversity}

An ecosystem encompasses the living components (plants, animals, and icrobial life) of a local environment interacting with the abiotic (non-living) components of the environment. $^{294}$ Such sets of living organisms and the non-living environment within which they subsist, interact in a system. ${ }^{295}$ Examples of objects of study in relation to ecosystems involve examination of the mechanics of nutrient flow within a food web and within processes of metabolism, oxidation, respiration, photosynthesis, and other basic metabolic processes in the living organisms within the system. ${ }^{296}$ Relevant questions relate to how the diversity of a particular species, and the diversity of individual organisms within a species, affect the behavior of the whole ecosystem. ${ }^{297}$

A central aspect of an ecosystem is its biological diversity, or "biodiversity," the variability of forms of life that subsist at different levels of organization. ${ }^{298}$ Biodiversity

1

294. SACHS, The AgE OF SuStAinABLE DEVElOPMENT (2015), supra note 73, at 448.

295. Id.

296. Id.

297. Id.

298. Sachs, The Age of Sustainable DeVElopment (2015), supra note 73, at 448. 
includes the variability of life within particular species, the diversity of species within an ecosystem, and the various relationships in which each species is involved, such as predator and prey. ${ }^{299}$ The interactions of species within an ecosystem determine certain fundamental characteristics of the ecosystem, such as whether it is biologically productive, and whether it is resilient to shocks, such as climate change, the introduction of new species, or overharvesting (by such actions as fishing, logging, or hunting). ${ }^{300}$

Biodiversity affects also the interactions of ecosystems, such as those of desert ecosystems with humid ecosystems. ${ }^{301}$ If a critically important ecological unit, such as the Arctic region, suffers a major change as a result, for example, of humaninduced climate change, the impact of such a change on other ecosystems can be significant, by processes such as precipitation, winds, ocean circulation, chemical changes, and others. ${ }^{302}$

In substance, ecosystems provide four categories of service. ${ }^{\mathbf{3 0 3}}$ The first of these categories, provisioning services, includes the ways that ecosystems directly supply human needs, such as food, fresh water, clothing, building materials, and fuels. ${ }^{304}$ The second category includes regulatory services, such as functions that control the basic patterns of climate, disease transmission, and nutrient cycling. ${ }^{305}$

299. SACHS, THE AGE OF SUSTAINABLE DEVELOPMENT (2015), supra note 73, at 448.

300. Id.

301. Sachs, The Age Of Sustainable DeVelopment (2015), supra note 73, at 449.

302. Id.

303. Id.

304. Id.

305. Id. 
The melting of the great ice sheets of Antarctica and Greenland, would, for instance, cause significant rises in ocean levels worldwide. ${ }^{306}$ Topographical features, such as mangrove swamps, often protect human populations living near coastlines. $^{307}$ The third category of ecosystem services includes supporting services, such as nutrient cycling and the formation of soils through interactions of biotic and abiotic processes. ${ }^{308}$ The fourth and final category of ecosystem services has been termed "cultural services," and encompasses the ways in which ecosystems enhance human values: aesthetics, religion, and culture in general. ${ }^{\mathbf{3 0 9}}$ By its very nature, the implication of the fourth category of ecosystem services is that degradation of natural environments can deeply upset human cultures, mental wellbeing, aesthetics, and overall quality of life. ${ }^{310}$

Biodiversity supports and promotes the health, vitality, and productivity of ecosystems. ${ }^{311}$ When biodiversity is adversely affected, ecosystem functions are diminished. ${ }^{312}$ Scientists have confirmed, for example, that a reduction of biodiversity of species of fish leads to a reduction in the productivity of fisheries, and crop yields, in the long term, are higher in farm systems that have higher biodiversity. ${ }^{\mathbf{3 1 3}}$ In summary, ecosystem services are essential for human survival, and biodiversity

306. Sachs, The Age Of Sustainable DeVelopment (2015), supra note 73, at 449.

307. Id. at 450

308. SAChS, The Age of Sustainable DeVElopment (2015), supra note 73, at 451.

309. Id.

310. Sachs, The Age of Sustainable DeVelopment (2015), supra note 73, at 452.

311. Id.

312. Id.

313. Id. 
is essential for the healthy functioning of ecosystems. ${ }^{314}$ However, biodiversity is generally under unprecedented threat as the direct result of human activity the world over, which is undermining the support structures upon which its biological survival and cultural vitality depend. ${ }^{315}$

The human impact on biodiversity is significant in all parts of the world, except in the most extreme environments, notably the desert regions, some parts of the equatorial rain forests, and the polar regions. ${ }^{316}$ A measure of this impact is to be found in the fact that humanity is now taking as much as $40-50$ percent of all of the photosynthesis on the planet. ${ }^{317}$ As human population has increased ten-fold since 1750 , humanity has claimed more and more land to grow grains, raise livestock, and provision its own numbers with forest products and fibers. $^{318}$

Humanity has fundamentally altered the carbon cycle, raising the level of carbon dioxide in the atmosphere from 280 parts per million (ppm) at the beginning of the Industrial Age to $400 \mathrm{ppm}$ at the beginning of the twenty-first century. ${ }^{319}$ Humanity has appropriated amounts of water to the extent that it faces water crises in many parts of the world. ${ }^{\mathbf{3 2 0}}$ Humanity has dominated the nitrogen cycle, transforming atmospheric nitrogen into reactive nitrogen compounds such

314. Sachs, The Age Of Sustainable DeVelopment (2015), supra note 73, at 452.

315. Id.

316. Id. at 454 .

317. Id. at 456 .

318. Id.

319. Id.

320. Id. 
as nitrates, nitrites, and ammonia, that can be used by plants. ${ }^{321}$ Further, humanity has introduced many invasive species into ecosystems, significantly disrupting ecosystems and food webs. ${ }^{\mathbf{3 2 2}}$ Finally, humanity has undermined supplies of fish in all parts of the world, by systematic overfishing, and such activities as the destruction of sea-beds and coral reefs. ${ }^{323}$

\section{(2) Extinctions of Species}

Scientific assessments of ecological health, conducted by the United Nations, the World Wildlife Fund (WWF), and others, indicate that the state of the Earth's ecosystems has changed more rapidly in the last 50 years than during any previous comparable period in human history. ${ }^{324}$ A process known as "the Sixth Mass Extinction" is said to be currently underway, with species becoming extinct at a rate not observed in 65 million years. ${ }^{325}$ Conservation biologists estimate that, if present processes continue unchecked, about 20 percent of all currently existing species on the Earth will be extinct by 2030, and 50 percent of all known earthly forms of life by the year $2050 .{ }^{\mathbf{3 2 6}}$

The primary causes of the extinction currently said to be in progress have been identified as categories of human activity that have resulted in habitat

321. Sachs, The Age of Sustainable DeVelopment (2015), supra note 73, at 456.

322. Id.

323. Id. at 457.

324. ROBERTSON, supra note 47 , at 114 , (citing Millennium Ecosystem Assessment, Ecosystems and Human Well-Being: Synthesis, at 1 (Washington, DC: Island Press 2005)).

325. ROBERTSON, supra note 47, at 114.

326. ROBERTSON, supra note 47 , at 115 , (citing Wilson, Edward O., The Future of Life, at 102 (London: Abacus 2002)). 
destruction, species invasions, pollution, and overexploitation. ${ }^{327}$ The effects of these factors have been heightened by the impacts of climate change and significant increases in human population. ${ }^{328}$

\section{(a) Destruction of Habitats}

The habitat of a living organism is defined as the place where it subsists, and finds food, water, cover, and space to grow and reproduce. ${ }^{329}$ The destruction of the habitats of various species has been identified as the most significant cause of ecosystem damage, biodiversity loss, and species extinction, and has been traced primarily to various human activities. ${ }^{\mathbf{3 3 0}}$

Sustainability professionals report that large areas of ocean floor habitat are destroyed each year by trawlers dragging heavily weighted nets across ocean floors. ${ }^{331}$ Corresponding damage is done to land habitats by practices such as clearcutting, in which every tree in a designated area is cut, regardless of size. ${ }^{\mathbf{3 3 2}}$ The clearing of land for crops has been identified as the human activity responsible proportionately for the largest destruction of terrestrial habitats. ${ }^{333}$ Tropical rainforests, considered the richest reservoirs of species in the world, and important sinks for sequestering carbon, are reported to be under practices of cutting and removal (“deforestation") at the rate of 1 percent of their total area per year. ${ }^{334}$

327. ROBERTSON, supra note 47, at 117.

328. ROBERTSON, supra note 47, at 115.

329. ROBERTSON, supra note 47, at 117.

330. Id.

331. Id.

332. Id.

333. Id.

334. ROBERTSON, supra note 47, at 117, (citing Flannery, Tim, An Ecological History of North America and its Peoples, at 79), (New York: Grove Press 2001)). 
Urban development, through its multiple processes of appropriation and alteration of large expanses of land for metropolitan usage, represents another category of human activity responsible for significant destruction of habitat resources. ${ }^{\mathbf{3 3 5}}$ Wetlands, which consist of land areas with soil saturated with water for at least part of each year, perform the vital functions of absorbing floodwaters, balancing stream flows, purifying water, and replenishing aquifers. Wetlands are critically important habitats for varied species of birds, fish, and small animals. ${ }^{\mathbf{3 3 6}}$ Reports indicate that more than half of the wetlands in the United States, and Australia, and over 60 percent of such resources in Canada, Europe, and China, have been filled or drained to create farmlands and build cities. ${ }^{337}$

There are indications that lakes and river systems are possibly the most threatened of terrestrial ecosystems. ${ }^{338}$ Plants, animals, and organisms that subsist in such media tend to evolve characteristics specific to their particular sites. ${ }^{\mathbf{3 3 9}}$ Alterations to such systems, by the building of dams across rivers, and development that involves removal of vegetation, often introduce conditions that are destructive to the inhabiting species. ${ }^{\mathbf{3 4 0}}$ The fragmentation of habitats, as for instance, by the construction of roads, has been indicated as another way such resources are marginalized and diminished by human activities. ${ }^{\mathbf{3 4 1}}$

335. ROBERTSON, supra note 47, at 118.

336. Id.

337. ROBERTSON, supra note 47, at 118 , (citing Mitsch, William J. and James G. Gosselink, Wetlands, at 48 (4th ed. New York: John Wiley 2007)).

338. ROBERTSON, supra note 47, at 118.

339. Id.

340. Id.

341. Id. 


\section{(b) The Impact of Invasive Species}

In the last 200 years, significant numbers of native species of plants, animals, and other organisms of specific habitats have been subjected to attacks by invading species that move in after having developed in other environments. ${ }^{342}$ Invading species in such scenarios are often more efficient than the natives at utilizing nutrients and other resources, and can take over habitats, driving some of the natives to extinction. ${ }^{343}$ Invading species, some of which are intentionally introduced to particular habitats by human activities and processes, often create irreversible problems, proving in cases to be impossible to remove after they become established new communities. ${ }^{344}$

\section{(c) Pollution of Habitats}

The impact of pollution on habitats is often more subtle than the effects of overt habitat destruction, fragmentation, and invasion by alien species. ${ }^{345}$ The effect of pollution on habitats is essentially the introduction of toxic substances into environments that are not equipped to process them. ${ }^{346}$ Sources of pollution include industrial waste, automobile exhaust, fertilizer compounds washed from fields by irrigation, and runoff from contaminated rainwater. ${ }^{347}$ Atmospheric pollution can damage entire ecosystems with deposits of toxic metals, ground- level ozone, acid rain and other substances. ${ }^{348}$

342. ROBERTSON, supra note 47, at 119.

343. Id.

344. ROBERTSON, supra note 47, at 120.

345. Id.

346. Id.

347. Id.

348. Id. 
(d) The Impact of Human Population Growth

Observers have argued that the effects of the growth of human populations are the primary cause of the current extinction. ${ }^{349}$ The origins of the human species have been traced to the African savanna, but human societies have spread and adapted to every continent except Antarctica. ${ }^{350}$ Observers assert that, if the Earth's human population lived within the planet's "carrying capacity," there would be "little to no habitat destruction, spread of invasive species, pollution, or overexploitation., ${ }^{, 351}$

\section{(e) Overexploitation of Resources}

When a natural resource is used up at an unsustainable rate, it is said to be “overexploited" or, alternatively, "overharvested."352 The stock of a fishery is said said to be at the point of collapse when it is 90 percent depleted. ${ }^{353}$ Biologists have estimated that, if current rates of harvesting of fish continue, all major fish stocks could be in a state of collapse by the year $2050 .{ }^{354}$

The overharvesting of trees in old-growth forests involves similar risks of irreversible damage. ${ }^{355}$ Some old-growth forests are over 1,000 years old, and contain trees of a range of ages, with rich diversities of microhabitats, which

$\begin{array}{ll}\text { 349. } & \text { Id. } \\ \text { 350. } & \text { Id. } \\ \text { 351. } & \text { ROBERTSON, supra note } 47, \text { at } 121 . \\ \text { 352. } & \text { Id. } \\ \text { 353. } & \text { Id. } \\ \text { 354. } & \text { Id. } \\ \text { 355. } & \text { Id. }\end{array}$


cannot be restored by simple processes of replanting. ${ }^{356}$ It is reported that over 90 percent of old-growth forests in the U.S. have been destroyed. ${ }^{357}$

(3) Conservation, Restoration, and Reconciliation

Conservation, restoration, and reconciliation have been identified as three categories of approach to maintaining the health of the natural world. ${ }^{358}$ Conservation is applicable to the preservation of resources that are already in existence. $^{359}$ Restoration refers to repairing damage, to return the condition of an ecosystem to an earlier state of health. ${ }^{360}$ Reconciliation involves recognizing that human beings are part of the natural world, and finding ways in which the human and non-human spheres of life can exist harmoniously, for the benefit of both. ${ }^{\mathbf{3 6 1}}$ Ecosystems have "trajectories" that trace their paths through various states of existence. ${ }^{362}$ Some conservation or restoration projects have goals of maintaining ecosystem in particular states. ${ }^{363}$ Others attempt to guide ecosystems through favored states of transition. ${ }^{364}$ Forces of apparent "disturbance," such as wind, flood, fire, grazing, insects, and disease, play important roles in maintaining ecosystem integrity. in

356. ROBERTSON, supra note 47 , at 121 , (citing Cunningham, William P. and Mary Ann Cunningham, Environment Science: A Global Concern, at 235 (11h ed. New York: McGraw-Hill 2010)).

357. Id.

358. Id.

359. ROBERTSON, supra note 47 , at 121 , (citing Cunningham, William P. and Mary Ann Cunningham, Environment Science: A Global Concern, at 260 (11th ed. New York: McGraw-Hill 2010)).

360. ROBERTSON, supra note 47, at 122.

361. Id.

362. Id.

363. Id.

364. Id. 
For instance, the floodplain of a river without periodic incidences of flood, will decline as it loses its infusions of nutrient-rich silt. ${ }^{365}$

Phenomena of "disturbance," such as wind, flood, fire, grazing, insects, and disease, produce varied complex structures in ecosystems, that serve as habitats for a wide range of plants and animals. ${ }^{366}$ Diversities of structure brought about by variations in age also serve to accommodate ranges of organisms with different habitat needs. ${ }^{\mathbf{3 6 7}}$ Biodiversity is dependent, to a significant extent, on the structural complexity of ecosystems. $^{368}$

The organisms within a particular ecosystem are interrelated to each other through biological mechanisms for exchanges of energy, food, and waste; and the ecosystem itself is connected to the external world, and shaped by the attributes and activities of that world. ${ }^{369}$ The quality of "resilience" of an ecosystem is its capacity to accommodate change, while retaining its essential functionality, structure, and identity. ${ }^{\mathbf{3 7 0}}$ Resilience permits systems to rebuild themselves, to adapt, and to absorb disturbance while maintaining their basic functions. ${ }^{371}$

(a) Conservation of Natural Resources

Methods of conservation suggest three criteria for the selection of species

365. ROBERTSON, supra note 47 , at 122.

366. Id.

367. Id.

368. ROBERTSON, supra note 47, at 122.

369. Id.

370. Id.

371. ROBERTSON, supra note 47 , at 123. 
or ecosystems for efforts of preservation: distinctiveness, endangerment, and utility. ${ }^{372}$ The criterion of "distinctiveness" implies that an ecosystem that contains mostly rare species has a higher priority than an ecosystem that contains mostly common species. ${ }^{373}$ The criterion of "endangerment" implies that species in danger of extinction have a higher priority than species that are not in such danger. ${ }^{374}$ The criterion of "utility" implies that species or ecosystems that carry potential value to humans have a higher priority than those that do not. ${ }^{375}$

In view of the scarcity of implementation resources, conservation planners have developed additional criteria to be used in the selection of ecosystems for preservation: representation, resiliency, redundancy, and reality. ${ }^{376}$ Under these criteria, an ecosystem to be selected for conservation should be "representative," in that it should contain the species and habitat features of a functioning ecosystem of its type. ${ }^{377}$ It should be "resilient," in that it should be capable of maintaining its functions over the foreseeable future in the face of natural disturbances ${ }^{378}$ It should contain a "redundancy" of species numbers in

372. Id.

373. Id.

374. ROBERTSON, supra note 47, at 123, (citing Primack, Richard B., A Primer of Conservation Biology, at 206 (4th ed. Sunderland MA: Sinauer Associates 2008)).

375. ROBERTSON, supra note 47, at 123.

376. Id.

377. Id.

378. ROBERTSON, supra note 47, at 123 , (citing Primack, Richard B., A Primer of Conservation Biology, at 214 (4th ed. Sunderland, MA: Sinauer Associates 2008)). 
anticipation of extinctions of particular populations. ${ }^{379}$ And finally, the conservation planner must maintain a pragmatic perspective in regard to the extent of financial and political support available for the completion of his or her task. $^{380}$

\section{(b) Restoration Ecology}

Restoration is a remedial approach to maintaining the health of the resources of nature. The Society for Ecological Restoration (SER) has provided the following definition of the term: "Ecological restoration is the process of assisting the recovery of an ecosystem that has been degraded, damaged, or destroyed. ${ }^{, 381}$ In general, the process of restoration involves an assessment of existing conditions, identification of the processes that led to degradation, the formulation of a plan for restoration of health, the monitoring of subsequent progress, and the use of techniques of adaptive management to adjust the plan as required. ${ }^{382}$

The process of forest restoration includes the closing of roads, removal of invasive species, and controlling of livestock grazing. ${ }^{383}$ Since forest diversity is dependent on phenomena of "disturbances" such as fire and wind, locations, controlled fires (known as "prescribed burns") can be used to simulate the effects

377. ROBERTSON, supra note 47 , at 123.

378. Id.

379. ROBERTSON, supra note 47 , at 124.

380. Id.

381. ROBERTSON, supra note 47, at 126.

382. Id.

383. ROBERTSON, supra note 47, at 127. 
of lightning-caused fires. ${ }^{\mathbf{3 8 4}}$ The restoration of prairies involves the removal of pressures imposed by livestock grazing, clearing of soil, and planting of native prairie species. $^{\mathbf{3 8 5}}$

The restoration of wetlands involves essentially the restoration of hydrology. ${ }^{386}$ Such measures typically include the removal of sources of pollution, removal of any filler material previously applied, and regrading to simulate natural topography, and hydrology. ${ }^{\mathbf{3 8 7}}$ Appropriate native species of vegetation are replanted, using genetic stock from the same geographical area. ${ }^{\mathbf{3 8 8}}$ Given the complexity of wetlands, the choice of ecologists is sometimes to allow native species to recolonize an area on their own. ${ }^{\mathbf{3 8 9}}$ The restoration of streams involves essentially the removal of obstacles, so that the system can resume its natural functionality. ${ }^{390}$

\section{(c) Reconciliation Ecology}

The term, "reconciliation ecology," is used to describe the deliberate sharing, between human and other forms of life, of the living spaces of the Earth. ${ }^{391}$ Such arrangements will require, on the part of the human community, an understanding of, and adaptation to, the needs of other species. ${ }^{392}$ Habitats in

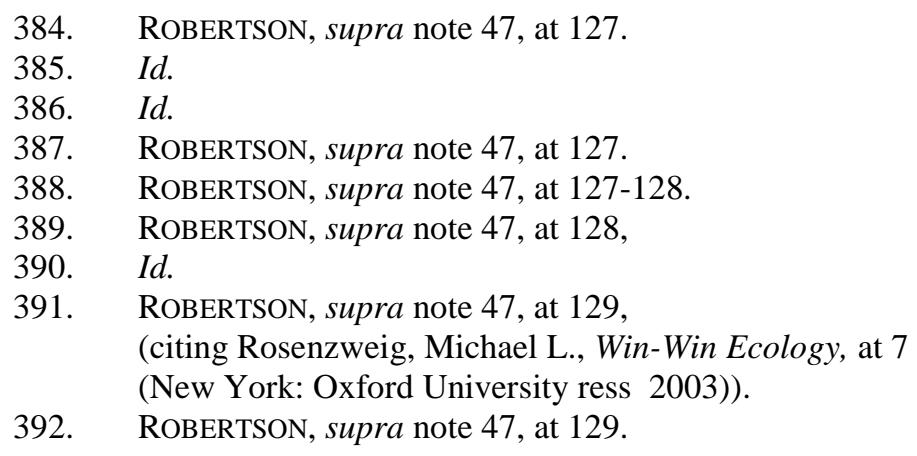


the midst of human living spaces, will not be an ideal arrangement for most species, but could allow, at least, some to survive. ${ }^{393}$ A conceptual picture of reconciliation ecology presented by an observer is that of "a city where green roofs, small backyards, town squares, larger parks, school grounds, and tree-filled cemeteries are all functioning ecosystems dotting the city with patches of habitat, all connected together into a green network by greenways, vegetated swales, and healthy stream corridors.

\section{(4) Summation of Issues in Regard to Ecosystems \& Habitats}

A significant cause of the species extinction currently reported to be in progress, has been identified as human activity that has resulted in native habitat destruction, species invasions, pollution, population growth and overexploitation of natural resources. ${ }^{395}$ The heavy-net trawling of ocean floors, clearing of forests, development of urban areas, damming of rivers, the introduction of destructive alien organisms into vulnerable habitats, and the uncontrolled release of highly toxic substances, are instances of these human activities. ${ }^{396}$ The effects of these activities have been magnified by the impacts of climate change. ${ }^{397}$

Conservation, restoration, and reconciliation have been indicated as three categories of approach for maintaining the health of ecosystems and habitats. ${ }^{398}$

393. Id.

394. Id.

395. See supra text referenced by notes 294-327.

396. See supra text referenced by notes 331-348.

397. See supra note 328.

398. See supra text referenced by notes $372-394$. 
The methods of conservation are applicable to the preservation of resources that are already in existence. ${ }^{399}$ Restoration refers to the repairing of damage, to return the condition of an ecosystem to an earlier state of health. ${ }^{400}$ Reconciliation involves the deliberate, planned, and systematic sharing of the living spaces and other resources of the Earth, between human and other forms of life. $^{401}$ Such arrangements will require, on the part of the human community, a comprehensive understanding of, and adaptation to, the needs of other species. ${ }^{\mathbf{4 0 2}}$

\section{G. Issues in Regard to Pollution}

Section G of Part II provides an account of issues relating to the needs encountered. For the sustained preservation of the Earth's resources from the effective use of human-induced pollution should be considered a logical choice. A pollutant is generally identified as an unwanted substance that is harmful to the environment into which it is introduced. ${ }^{403}$ Pollutants can be derived from natural sources such as volcanic eruptions; organic sources such as sewage; and from synthetic chemicals produced by human activities. ${ }^{404}$ The issues of pollution are interrelated with those of climate change, the availability of water, and protection of ecosystems, and should, therefore, be dealt with in consonance with the principles and processes of sustainability.

399. See supra text referenced by notes 372-380.

400. See supra text referenced by notes 381-390.

401. See supra text referenced by notes 391-394.

402. See supra note 391-392.

403. ROBERTSON, supra note 47, at 135.

404. Id. 


\section{(1) Types of Toxins}

Allergens are toxins that trigger unneeded responses by the organism's immune system. ${ }^{\mathbf{4 0 5}}$ Formaldehyde is a strong allergen used in building materials. ${ }^{406}$ Immune system depressants suppress the organism's immune system, increasing its susceptibility

to infection. ${ }^{407}$ Examples of immune system depressants include certain pesticides and the now-banned polychlorinated biphenyls (PCBs). ${ }^{408}$

Mutagens are substances that damage genetic material in cells, and for which no safe threshold appears to exist. ${ }^{409}$ Some mutagens are carcinogens, which are known to increase the risk of cancer. ${ }^{\mathbf{4 1 0}}$ Teratogens, such as mercury, lead, and alcohol, are toxins that cause abnormalities in developing embryos. ${ }^{411}$ Neurotoxins, substances that cause permanent damage to nerve cells, include heavy metals such as lead, arsenic, and mercury; and many pesticides, including the now-banned DDT. ${ }^{412}$ Endocrine disruptors are substances that interfere with hormone functions. ${ }^{413}$

\section{(2) Pollution Media}

(a) Air Pollution

Airborne pollutants are reported to cause more health problems than those transported by any other media. ${ }^{\mathbf{4 1 4}}$ In the U.S. the Environmental Protection Agency (EPA) has identified a category of six major air pollutants, termed "criteria

$\begin{array}{ll}\text { 405. } & I d . \\ 406 . & I d . \\ 407 . & \text { ROBERTSON, supra note } 47, \text { at } 136 . \\ 408 . & I d . \\ 409 . & \text { ROBERTSON, supra note } 47, \text { at } 136 . \\ 410 . & I d . \\ 411 . & I d . \\ 412 . & I d . \\ 413 . & I d . \\ 414 . & \text { ROBERTSON, supra } \text { note } 47, \text { at } 138 .\end{array}$


pollutants," considered to pose the most serious threats to human health. ${ }^{415}$ The six criteria pollutants, noted as such by the EPA, are: particulates, carbon monoxide, sulfur oxides, nitrogen oxides, lead, and ground-level ozone. ${ }^{416}$

\section{(2) Pollution Media}

\section{(a) Air Pollution}

Particulates comprise solid or liquid matter, suspended as minute particles in air or water. ${ }^{417}$ Airborne particulates are termed aerosols. ${ }^{418}$ Particulates can be be made up of a variety of substances, including soot, smoke, dust, pollen, metals, organic chemicals, and acids. ${ }^{419}$ Particulates have been identified as one of the most serious sources of health problems in industrialized nations. ${ }^{\mathbf{4 2 0}}$

Carbon monoxide $(\mathrm{CO})$ has been identified as the major pollutant in urban air, most of it released by the incomplete combustion of fossil fuels. ${ }^{421}$ Long-term exposure to carbon monoxide has been reported as a cause of adverse heart conditions, and as a risk to pregnant women. ${ }^{422}$ Further, it has been indicated that carbon monoxide reduces the ability of the Earth to regulate levels of the greenhouse, methane. ${ }^{423}$

Sulfur dioxide $\left(\mathrm{SO}_{2}\right)$, a colorless gas with a strong, distinctive smell, has

$\begin{array}{ll}\text { 415. } & \text { Id. } \\ \text { 416. } & \text { Id. } \\ 417 . & \text { ROBERTSON, supra note } 47, \text { at } 138 . \\ 418 . & I d . \\ 419 . & I d . \\ 420 . & I d . \\ 421 . & \text { ROBERTSON, supra note } 47, \text { at } 139 . \\ 422 . & I d . \\ 423 . & I d\end{array}$


Been identified as the primary source of atmospheric sulfur pollution. ${ }^{\mathbf{4 2 4}}$ Ninety percent of the sulfur dioxide in the Earth's atmosphere is estimated to have originated in processes involving the burning of fossil fuels, particularly coal. $^{\mathbf{4 2 5}}$ Sulfur dioxide causes respiratory problems, partly because of its propensity to form corrosive sulfuric acid as a result of reactions with moisture in the mucous membranes and lungs of human beings and animals. ${ }^{\mathbf{4 2 6}}$

Nitrogen oxides $\left(\mathrm{NO}, \mathrm{NO}_{2}, \mathrm{~N}_{2} \mathrm{O}\right)$ are among the compounds identified as greenhouse gases. ${ }^{\mathbf{4 2 7}}$ These gases irritate lungs and mucous membranes, and increase the risk of premature death of people with congestive heart conditions. ${ }^{\mathbf{4 2 8}}$ Lead is a highly toxic heavy metal, a neurotoxin, that is emitted by lead smelters, waste incinerators, coal-fired power plants, and lead-acid battery manufacturing. ${ }^{\mathbf{4 2 9}}$

Secondary air-pollutants are identified as substances formed in chemical reactions that occur after primary pollutants enter the atmosphere. ${ }^{\mathbf{4 3 0}}$ Groundlevel ozone, one of the EPA's six criteria pollutants, is one of the most significant of secondary pollutants. ${ }^{431}$ Each molecule of ozone $\left(\mathrm{O}_{3}\right)$ contains three oxygen atoms, in contrast to the molecule of ordinary atmospheric oxygen $\left(\mathrm{O}_{2}\right)$, each of

424. ROBERTSON, supra note 47 , at 139.

425. ROBERTSON, supra note 47 , at 139 ,

(citing Pepper, Ian L., Charles P. Gerba, and Mark L. Brusseau, eds. Environmental and Pollution Science, at 382 (2nd ed. Boston: Academic Press 2006)).

426. ROBERTSON, supra note 47, at 139.

427. ROBERTSON, supra note 47, at 140.

428. ROBERTSON, supra note 47, at 140 (citing Pepper, Ian L., Charles P. Gerba, and Mark L. Brusseau, eds. Environmental and Pollution Science, at 383 (2nd ed. Boston: Academic Press 2006)).

429. ROBERTSON, supra note 47 , at 140.

430. Id.

431. Id. 
which contains two oxygen atoms. ${ }^{432}$ Ground-level ozone forms in chemical reactions between nitrogen oxides and volatile organic compounds in the presence of sunlight. ${ }^{433}$ While ozone in the stratosphere is necessary for life, an excess of ozone in the troposphere or lower atmosphere is considered a health hazard. $^{\mathbf{4 3 4}}$ The breathing of ozone can irritate mucous membranes, and impair lung function. ${ }^{435}$

In addition to the six criteria pollutants discussed in the foregoing material, the EPA has identified a list of particularly dangerous chemicals, termed "hazardous air pollutants" (HAPs), which includes 187 carcinogens, mutagens, neurotoxins, endocrine disruptors, and other highly toxic substances. ${ }^{\mathbf{4 3 6}}$ These pollutants, while not as pervasive nor present in as large quantities as the criteria pollutants, can accumulate, and often persist in the environment for long periods of time. ${ }^{437}$

(b) Soil and Land Pollution

Activities that can contaminate soil include mining and oil drilling. ${ }^{\mathbf{4 3 8}}$ Mining involves the removal of masses of soil and rock from the earth, processing it with chemicals, and depositing the remains in large piles. ${ }^{439}$ The processed material, known as mine tailings, is pumped, together with liquid, into pits. ${ }^{400}$

$\begin{array}{ll}\text { 432. } & \text { Id. } \\ 433 . & I d . \\ 434 . & \text { RoBERTSON, supra note } 47, \text { at } 140 . \\ 435 . & \text { Id. } \\ 436 . & \text { ROBERTSON, supra note } 47, \text { at } 141 . \\ 437 & I d . \\ 438 . & I d . \\ 439 . & I d . \\ 440 . & I d .\end{array}$


Processes of drilling for oil use large quantities of drilling fluids, which are disposed of in storage pits, evaporation ponds, or the ocean (in cases of off-shore drilling). ${ }^{441}$ Such waste materials are termed "exploration and production" waste, and, in the United States, are exempt from hazardous waste regulations. ${ }^{\mathbf{4 4 2}}$

\section{(c) Water Pollution}

Because of its properties as "the universal solvent," water is readily contaminated, and difficult to restore to a pure state. ${ }^{\mathbf{4 4 3}}$ In the United States, the Clean Water Act requires each state to establish and monitor "Total Daily Maximum Loads (TDMLs)" for types and levels of pollution. ${ }^{444}$ The U.S. Clean Water Act classifies water pollutants within the categories, "conventional pollutants", “priority pollutants", and “nonconventional pollutants.",445

“Conventional pollutants," as classified by the EPA, include oxygendepleting bacteria, suspended solids, fecal coliform bacteria, and oil and grease. ${ }^{\mathbf{4 6}}$ The term, "priority pollutants" is applied by the EPA to elements and compounds on a list that includes heavy metals, volatile hydrocarbons, and many pesticides. ${ }^{447}$ The third category of water pollutants regulated by the EPA, termed “nonconventional pollutants," includes pollutants not classified as "conventional" or "priority" pollutants. ${ }^{448}$

441. ROBERTSON, supra note 47, at 141.

442. Id.

443. ROBERTSON, supra note 47, at 141.

444. ROBERTSON, supra note 47, at 142.

445. Id.

446. Id.

447. Id.

448. ROBERTSON, supra note 47, at 143. 
Since groundwater sealed from light and air is particularly susceptible to contamination, it is critically important that underground stores of water, such as aquifers, are adequately protected from sources of pollution. ${ }^{449}$ Aquifers with the highest risk of contamination are those positioned near surfaces comprised of porous soil, and located in areas of high rainfall. ${ }^{\mathbf{4 5 0}}$

\section{(3) Pollution Remediation}

Pollution remediation involves evaluating, halting, and reversing damage to environmental systems caused by pollution. ${ }^{451}$ The process begins with the step of "site characterization," - the gathering and analysis of information about the site and its problems. ${ }^{\mathbf{4 5 2}}$ A remediation plan is subsequently drawn up, and contamination eliminated through processes of containment, removal, or

treatment. ${ }^{453}$ Bacteria are used for a great deal of the cleanup work. ${ }^{454}$ Following remediation, some sites require monitoring for 10 years or longer. ${ }^{\mathbf{4 5 5}}$

\section{(4) Pollution Prevention}

Since even the best practices of remediation cannot produce optimal results, the prevention of pollution must be considered the preferred option under sustainability principles. ${ }^{\mathbf{4 5 6}}$ The "Precautionary Principle" is one of 27 stated in

449. Id.

450. ROBERTSON, supra note 47 , at 143

(citing Pepper, Ian L., Charles P. Gerba, and Mark L. Brusseau, eds. Environmental and Pollution Science, at 265 (2nd ed. Boston: Academic Press 2006

451. ROBERTSON, supra note 47, at 147.

452. ROBERTSON, supra note 47 , at 148.

453. $I d$.

454. Id.

455. Id.

456. ROBERTSON, supra note 47 , at 155. 
the Rio Declaration of $1992 .{ }^{457}$ The principle generally advocates precautionary measures, even in situations in which dangerous cause-and-effect relationships have not been established with scientific certainty. ${ }^{\mathbf{4 5 8}}$

The U.S. Pollution Prevention Act of 1990 contains a framework embodying a hierarchy of methods for dealing with issues in regard to waste streams. ${ }^{459}$ The highest priority is to reduce or eliminate pollution at its source. ${ }^{\mathbf{4 6 0}}$ Approaches with lower priorities involve reusing or recycling what cannot be reduced, and developing means of disposing of pollution as a last resort. ${ }^{461}$

\section{(5) Summation of Issues in Regard to Pollution}

Pollutants may be classified as allergens, mutagens, teratogens, neurotoxins, and endocrine disruptors. ${ }^{\mathbf{4 6 2}}$ Airborne pollutants are reported to cause more health problems than those transported by any other media. ${ }^{463}$ Activities that can contaminate soil include mining and oil drilling. ${ }^{464}$ Because of its properties as a powerful solvent, water is readily contaminated, and difficult to restore to a pure state. ${ }^{\mathbf{4 6 5}}$

457. Id.

458. Id.

459. Id.

460. ROBERTSON, supra note 47 , at 155.

461. Id.

462. See supra text accompanying notes 405-413.

463. See supra text accompanying notes 414-437.

464. See supra text accompanying notes 438-442.

465. See supra text accompanying notes 443-450. 
Pollution remediation involves evaluating, halting, and reversing damage to environmental systems caused by pollution. ${ }^{466}$ Since even the most effective practices of remediation do not achieve complete restoration, the prevention of pollution must be considered the strongly preferred option under sustainability principles. ${ }^{467}$ The "Precautionary Principle," one of 27 principles stated in the Rio Declaration of 1992, advocates precautionary measures, even in situations in which dangerous cause-and-effect relationships have not been established with complete scientific certainty. ${ }^{468}$

\section{H. Issues in Regard to Energy}

Section $\mathrm{H}$ of Part II provides an account of issues relating to the generation of energy for the rapidly growing requirements of the modern world. Major problems of pollution and environmental degradation associated with the extraction, transportation, and use of fossil fuels, are compounded by the unavoidable fact that such fuels are not renewable. Alternative sources of energy, such as solar, geothermal, wind, and hydroelectric power are examined for their viability, and processes of transition to such sources evaluated for their feasibility.

\section{(1) Fossil Fuels}

Fossil fuels are categorized as a non-renewable resource, since their regeneration will require processes operating in time periods extending over hundreds of millions of

466. See supra text accompanying notes 451-455.

467. See supra text accompanying notes 456-460.

468. See supra text accompanying notes $457-458$. 
years. $^{469}$ Fossil fuels are hydrocarbon compounds that occur naturally in three forms: petroleum, natural gas, and coal. ${ }^{470}$ Of the three forms, petroleum and natural gas are primarily fossilized marine plankton, while coal is fossilized terrestrial plant material. ${ }^{471}$ All three types of fossil fuel were formed when masses of organic matter were subjected to conditions of extreme heat and pressure. $^{472}$

Petroleum is extracted by drilling - a process that generates waste that must be secured and stored. ${ }^{473}$ As land-based and marine oil fields have been depleted, producers have turned to non-conventional sources such as oil shales and tar sands. ${ }^{\mathbf{4 7 4}}$ Extraction from these sources is more difficult and expensive, and carries greater environmental risks than conventional drilling. ${ }^{475}$ Producers have also turned to new technologies for extracting natural gas from shale deposits. ${ }^{476}$ Since oil deposits are distributed unevenly around the world, methods of transportation, such as extensive networks of pipe-lines and fleets of massive ocean tankers, are deployed to move supplies from sources to points of demand. ${ }^{477}$

There are significant risks of pollution and environmental degradation associated with the extraction and use of fossil fuels. The combustion of coal

469. ROBERTSON, supra note 47, at 158 .

470. Id.

471. Id.

472. ROBERTSON, supra note 47, at 159 .

473. ROBERTSON, supra note 47, at 159-160.

474. ROBERTSON, supra note 47 , at 160.

475. Id.

476. Id.

477. Id. 
causes the emission of mercury, and generates sulfur and nitrogen oxides that produce photochemical smog and acid rain. ${ }^{478}$ The mining of coal results in the destruction of mountains, burial of streams, and the generation of massive quantities of contaminated waste. ${ }^{479}$

A major issue associated with the extraction and transportation of petroleum is the risk of accidental spillage, such as occurred in 2010 at the site of the Deepwater Horizon drilling platform in the Gulf of Mexico. ${ }^{480}$ The Deepwater Horizon platform spill resulted in the deaths of thousands of marine creatures. ${ }^{481}$ Another major mishap that may be noted in this connection is the 1989 Exxon Valdez oil spill in Prince William Sound, Alaska. ${ }^{482}$

Worldwide discoveries of petroleum were reported to have reached a peak in 2005, with new fields declining steadily in size. ${ }^{483}$ Natural gas is predicted to last for additional decades, or even centuries. ${ }^{\mathbf{4 8 4}}$ Coal is at present the most abundantly available of the fossil fuels, but at prevailing rates of consumption, its supplies are forecast to be depleted within a decade. ${ }^{\mathbf{4 8 5}}$

\section{(2) Renewable Sources of Energy}

Energy from the sun can be utilized directly through photovoltaic (PV)

478. ROBERTSON, supra note 47 , at 161.

479. Id.

480. Id.

481. Id.

482. ROBERTSON, supra note 47 , at 161.

483. Id.

484. Id.

485. ROBERTSON, supra note 47, at 163, (citing Lovins, Amory B. Reinventing Fire, at 8 (White River Junction, VT: Chelsea Green Publishing, 2011)). 
cells and by means of thermal energy. ${ }^{486}$ Photovoltaic cells are semiconductors using panels mounted with tubes that absorb heat from sunlight. ${ }^{487}$ Solar thermal technology, in which parabolic reflectors focus the sun's rays on small target areas, represents another way of generating electricity directly from the sun. ${ }^{\mathbf{4 8 8}}$

Geothermal heat is another renewable source of energy. The sources of geothermal heat are residual heat remaining from the violent collisions that formed the planet, radioactive decay, and tremendous pressures deep within the Earth caused by gravitational forces. ${ }^{489}$ In certain places, volcanism and hydrothermal activity are close to the surface of the Earth, and generate intense heat that that can be used to run steam turbines that generate power. ${ }^{490}$ In enhanced geothermal systems, deep wells are dug, water pumped through hot rocks below the the surface of the Earth, and returned to the surface as steam. ${ }^{491}$

Methods of "cogeneration" use waste heat from industrial plants to generate power. The US Steel Company and ArcelorMittal in Indiana are producers of steel that use processes of "cogeneration." Each entity generates about $90 \mathrm{MW}$ of power from waste heat left over from steelmaking. ${ }^{\mathbf{4 9 2}}$

Biomass comprises waste material from vegetation that is converted into energy directly by burning, or following conversion into fuel, which is then

486. ROBERTSON, supra note 47, at 166.

487. Id.

488. ROBERTSON, supra note 47, at 169.

489. ROBERTSON, supra note 47, at 166.

490. ROBERTSON, supra note 47, at 166-167.

491. ROBERTSON, supra note 47, at 167.

492. ROBERTSON, supra note 47, at 167, (citing Smil, Vaclav. Energy at the Crossroads, at 33 (Cambridge, MA: MIT Press (2003)). 
burned. ${ }^{493}$ Such material can be wood waste from sawmills, agricultural byproducts, or municipal solid waste. ${ }^{494}$ A negative aspect of the use of biomass as a source of energy is that, if the material burned contains heavy metals or synthetic chemicals, toxic emissions can result from the process. ${ }^{495}$ Further, wood smoke emitted in the burning of biomass material contains particulate matter and carcinogens. ${ }^{496}$ However, the burning of biomass is considered by some to be "carbon neutral," since it releases only carbon dioxide recently removed by plants from the atmosphere, together with that from processing. ${ }^{497}$

Hydroelectric power comprises a large proportion of the power generated by renewable energy sources. ${ }^{498}$ A significant advantage of hydroelectric power is that no greenhouse gases are produced in the course of its generation. ${ }^{499}$

Disadvantages include the facts that the construction of dams destroys ecosystems, blocks the migration of fish, and alters hydrological function. ${ }^{\mathbf{5 0 0}}$ The construction of dams also displaces people and obliterates cultural and archaeological sites. ${ }^{\mathbf{5 0 1}}$ The World Commission on Dams estimates that 40 to 80 million people worldwide have been forced to move because of the construction of dams. ${ }^{\mathbf{5 0 2}}$ Vegetation killed by reservoir waters, and silt accumulating behind dam structures, emit methane, a potent

493. ROBERTSON, supra note 47 , at 167.

494. Id.

495. Id.

496. Id.

497. ROBERTSON, supra note 47, at 167-168.

498. ROBERTSON, supra note 47, at 168.

499. Id..

$500 \quad I d .$.

501. Id..

502. Id.. 
nhouse gas. ${ }^{\mathbf{5 0 3}}$ Since methane has 25 times the greenhouse effect of carbon dioxide, some researchers believe that dams cause greater climate change damage than conventconventional power plants. ${ }^{\mathbf{5 0 4}}$ Concerns about environmental damage caused by dams have prompted a number of dam removal projects in France and the United States. ${ }^{\mathbf{5 0 5}}$

Wind power in the modern world is based on the use of turbines, a typical model of which would be equipped with three blades, each 50 to 100 feet long, on a horizontal axis mounted on a steel tower about 200-300 feet in height. ${ }^{\mathbf{5 0 6}}$ The generator is positioioned behind the hub of the blades in an enclosure known as a "nacelle."507 The nacelle contains equipment that regulates the speed of the generator, and optimizes blade adjustment in respect to wind speed and generator, and optimizes blade adjustment in respect to wind speed and direction. ${ }^{\mathbf{5 0 8}}$ Appropriate siting of wind turbine structures is necessary to protect wildlife, and to preserve the aesthetic qualities of natural surroundings. $^{509}$

The standard technology for making use of the massive amounts of energy that flow through the world's oceans in waves is the oscillating water column (OWC). ${ }^{\mathbf{5 1 0}}$ The OWC uses an enclosed chamber in which the rising and falling of water caused by wave action compresses air in the chamber, driving a turbine. ${ }^{511}$ Tidal energy technology uses differences in water level between low and high

$\begin{array}{ll}503 . & \text { Id.. } \\ 504 . & I d . . \\ 505 . & \text { Id.. } \\ 506 . & \text { ROBERTSON, supra } \text { note } 47, \text { at } 169 . \\ 507 . & I d . \\ 508 . & I d . \\ 509 & \text { ROBERTSON, supra note } 47, \text { at } 170 . \\ 510 . & I d . \\ 511 . & I d .\end{array}$


tides. $^{\mathbf{5 1 2}}$ The potential energy inherent in differences in water level is utilized by means of barrages or low walls that function in the manner of dam structures. ${ }^{\mathbf{5 1 3}}$ Tidal energy technology requires substantial differences in water level to function effectively. ${ }^{\mathbf{5 1 4}}$

"Biogas," an important fuel, is methane produced by anaerobic bacteria as they break down organic matter in waste materials. ${ }^{\mathbf{5 1 5}}$ Landfills are an important heaters. ${ }^{\mathbf{5 1 6}}$ Since natural gas is methane, biogas from landfills can be used in the same ways natural gas is used for energy production. ${ }^{\mathbf{5 1 7}}$ Biogas is also produced by means of anaerobic digesters used at sewage plants, animal feedlots, and poultry lots. ${ }^{\mathbf{5 1 8}}$

\section{(3) Alternative Sources of Energy for Transportation}

Transportation vehicles are, as a category, the heaviest user of petroleum, and a major source of carbon dioxide emissions. ${ }^{\mathbf{5 1 9}}$ Approaches to issues in this area could include improvements in vehicular operational efficiency, expansion of public transportation facilities, and the development of alternatives to fossil fuels, such as natural gas, electricity, biofuels, hydrogen, and fuel-cels. ${ }^{\mathbf{5 2 0}}$

Although natural gas, an alternative source of energy for transportation, is a fossil fuel, its combustion releases about 25 percent less carbon dioxide than that of gasoline. ${ }^{\mathbf{5 2 1}}$

512. Id.

513. ROBERTSON, supra note 47 , at 170-171.

514. ROBERTSON, supra note 47 , at 171.

515. Id.

516. ROBERTSON, supra note 47 , at 171.

517. Id.

518. Id.

519. Id.

520. Id.

521. ROBERTSON, supra note 47 , at 172 , (citing Randolph, John \& Gilbert M. Masters, Energy for Sustainability: Technology, Planning, Policy, at 580 (DC: Island Press (2008)). 
However, a transition to natural gas will require modifications in vehicular design. ${ }^{\mathbf{5 2}}$ Among the challenges associated with the use of electric vehicles are, (a) the fact that the generation of electric power involves significant levels of emission of greenhouse gases; and (b) issues related to the weight and size of batteries required to power vehicles. ${ }^{\mathbf{5 2 3}}$ Plug-in hybrid electric vehicles (PHEVs) use gasoline engines in concert with electric propulsion systems. ${ }^{\mathbf{5 2 4}}$ A PHEV's batteries are charged, not only by its engine, but through connection to a point in an electric grid. ${ }^{\mathbf{5 2 5}}$

The term, "biofuel" is typically applied to ethanol, whose production involves the conversion of some form of plant matter to sugars. ${ }^{\mathbf{5 2 6}}$ Four types of plant matter used in the conversion are: sugar cane; grain (usually corn or wheat); cellulosic crops; and biomass, such as crop residues or wood waste. ${ }^{\mathbf{5 2 7}}$ The use of corn as feedstock to produce biofuel, as is the predominant practice in the United States, has several negative spects. ${ }^{\mathbf{5 2 8}}$ Such application results in greater use of synthetic fertilizer, increases in the numbers of cultivators burning fossil fuels, and the appropriation of large expanses of agricultural land. ${ }^{\mathbf{5 2 9}}$ The use of cellulosic materials for the production of biofuel avoids most of these isssues. ${ }^{\mathbf{5 3 0}}$ Biodiesel is a form of biofuel made from oils, and is used as a replacement for diesel. ${ }^{531}$ Oils used to produce biodiesel include vegetable oils such as soybean or

522. ROBERTSON, supra note 47, at 172.

523. ROBERTSON, supra note 47, at 172.

524. Id.

525. Id.

526. ROBERTSON, supra note 47 , at 172-173.

527. ROBERTSON, supra note 47 , at 173.

528. Id.

529. Id.

530. Id.

531. Id. 
rapeseed oil. ${ }^{\mathbf{5 3 2}}$ An alternative source of oil to produce biodiesel, currently under active testing, involves the use of algae, and has been found to yield 100 to 300 more fuel per acre than crops. ${ }^{533}$

The advantages of use of hydrogen as an energy source is that it is the most abundant element in the universe, releases no greenhouse gases in combustion, and produces only water as a waste product. ${ }^{\mathbf{5 3 4}}$ Among the disadvantages of the use of hydrogen as an energy source is that its use is carbon-neutral only if the energy source used to produce it is carbon-neutral. ${ }^{\mathbf{5 3 5}}$

\section{(4) Energy Efficiency}

Energy efficiency is the lowest-cost alternative to fossil fuels, and the most expedient, since, as a practical matter, saving fuel is much cheaper than extracting, generating, or synthesizing it. ${ }^{\mathbf{5 3 6}}$ Further, it contributes to control of greenhouse gas emissions, since the "greenest" energy source is one not used. ${ }^{\mathbf{5 3 7}}$

Buildings account for a significant portion of all energy consumption in the modern world. ${ }^{538}$ Since existing buildings significantly outnumber new structures, the determination of more efficient ways to use energy in existing buildings represents one of the most effective ways to reduce fuel use and curb emissions. ${ }^{\mathbf{5 3 9}}$

532. Id.

533. ROBERTSON, supra note 47 , at 173.

534. Id.

535. Id.

536. ROBERTSON, supra note 47 , at 175.

537. Id.

538. Id.

539. Id. 
The steps in improving the energy performance of buildings involve definition of the problem, the gathering of information, the proposal and selection of alternatives, and implementation and evaluation of solutions. ${ }^{\mathbf{5 4 0}}$ Effective plans to improve energy performance of buildings typically adopt an integrated approach, evaluating a building as a unit whose components influence each other. ${ }^{\mathbf{5 4 1}}$ Energy efficiency measures can nvolve elements that influence energy use, such as operations and maintenance procedures, and upgrades to the building envelope. ${ }^{\mathbf{5 4 2}}$

\section{(5) The Difficulties of Transition}

In view of the massive investments in infrastructure and technology built on and around fossil fuels, it is apparent that it is not possible to switch the entire world economy abruptly to new sources of energy. ${ }^{\mathbf{5 4 3}}$ Analysts project that, even if sources of renewable energy develop rapidly, and cultural and political forces are supportive of such development, it will require decades to achieve a transition to a carbon-free economy worldwide. $^{544}$

Given the reality of unavoidable delays in the projected availability of renewable sources of energy, an inescapable alternative appears to lie in the development of processes and methods to increase " energy service" - the quantum of useful work obtained from each unit of fuel. ${ }^{\mathbf{5 4 5}}$

540. ROBERTSON, supra note 47, at 175.

541. ROBERTSON, supra note 47 , at 176.

542. Id.

543. ROBERTSON, supra note 47, at 179.

544. ROBERTSON, supra note 47, at 179 ,

(citing Ayres, Robert U. \& Edward H. Ayres, Crossing the Energy Divide, at 1

545. Id.

(Philadelphia: Wharton School Publishing (2010)). 
Increased levels of energy efficiency, and processes combining heat and power generation, are seen to be ways of promoting energy service. ${ }^{546}$ Potential strategies include changes in building design, material selection, and manufacturing process design; recycling, changing consumption rates, reducing the amount of water pumped over long distances; and rethinking approaches to urban land use planning. ${ }^{547}$

\section{(6) Summation of Issues in Regard to Energy}

Fossil fuels occur naturally in three forms, petroleum, natural gas, and and coal, and are categorized as a non-renewable resource. ${ }^{548}$ There are significant risks of pollution and environmental degradation associated with the extraction, transportation, and use of fossil fuels. ${ }^{549}$ Further, worldwide discoveries of petroleum were reported to have reached a peak in 2005 , with successive new fields declining steadily in size. ${ }^{500}$

Solar and geothermal energy are favored as renewable sources of energy. ${ }^{551}$ Methods of "cogeneration" use waste heat from industrial plants to generate power. ${ }^{52}$ Biomass comprises waste material from vegetation that is converted into energy directly by burning. ${ }^{553}$ A negative aspect of the use of biomass is that, if the material burned contains heavy metals or synthetic chemicals, toxic emissions can result from the process. ${ }^{554}$

546. ROBERTSON, supra note 47, at 179.

547. ROBERTSON, supra note 47, at 180.

548. Id. at $158-161$.

549. Id. at 161.

550. Id. at 163 .

551. Id. at 166-167.

552. ROBERTSON, supra note 47 , at 167.

553. Id.

554. Id. 
Hydroelectric power comprises a large proportion of the power generated by renewable energy sources. ${ }^{\mathbf{5 5 5}}$ Disadvantages associated with hydroelectric power include the facts that the construction of dams destroys ecosystems, blocks the migration paths of fish, and impairs critically important hydrological functions. ${ }^{\mathbf{5 5 6}}$ Wind power in the modern world is based on the use of turbines housed in steel towers, typically about 200-300 feet in height. ${ }^{557}$ The standard technology for making use of the massive amounts of energy that flow through the world's oceans in waves is the oscillating water column (OWC), in which the rising and falling of water caused by wave action compresses air in a chamber, driving a turbine. ${ }^{\mathbf{5 5 8}}$

Transportation vehicles are, as a category, the heaviest user of petroleum, and a major source of carbon dioxide emissions. ${ }^{\mathbf{5 5 9}}$ Approaches to issues in this area could include improvements in vehicular operational efficiency, expansion of public transportation facilities, and the development of alternatives to fossil fuels, such as natural gas, electricity, biofuels, hydrogen, and fuel-cels. ${ }^{\mathbf{5 6}}$

It has been recognized by scientists that energy efficiency is the lowestcost alternative to fossil fuels, and the most expedient, since, as a practical matter, saving fuel is much cheaper than extracting, generating, or synthesizing it. ${ }^{\mathbf{5 6 1}}$ Further, measures that promote energy efficiency contribute to control of green-

555. Id. at 168 .

556. ROBERTSON, supra note 47 , at 168.

557. ROBERTSON, supra note 47, at 169-170.

558. ROBERTSON, supra note 47 , at 170-171.

559. Id.

560. ROBERTSON, supra note 47, at 171-175.

561. ROBERTSON, supra note 47 , at 175-178. 
house gas emissions, since the "greenest" energy source is one not used. ${ }^{\mathbf{5 6 2}}$

In view of the massive investments in infrastructure and technology Built on and around the extraction and use of fossil fuels, it is apparent that a rapid, switch of the world economy to new sources of energy is not a realistic alternative. ${ }^{\mathbf{5 6 3}}$ Analysts project that, even if sources of renewable energy develop rapidly, and cultural and political forces are supportive of such development, it will require decades to achieve a transition to a carbon-free economy worldwide. $^{564}$

\section{Issues of Poverty and Inequality}

Section I of Part II examines prevailing world issues of poverty and inequality in relation to goals of sustainable development. United Nations General Assembly Resolutions A/RES/66/288 (Jul. 27, 2012), "The Future We Want,"565 and A/RES/70/1 (Sep. 25, 2015), "Transforming Our World: the 2030 Agenda for Sustainable Development,"566 contain emphatic statements on the continuing worldwide problems of poverty and inequality, and the urgent need to address these issues in effective ways. The material presented in this section of

562. ROBERTSON, supra note 47, at 175.

563. ROBERTSON, supra note 47, at 179.

564. ROBERTSON, supra note 47, at 179, (citing Ayres, Robert U. \& Edward H. Ayres, Crossing the Energy Divide, at 1 (Philadelphia: Wharton School Publishing (2010)).

565. United Nations General Assembly Resolution 66/288, The Future We Want, A/RES/66/288 (Jul. 27, 2012), supra note 17.

566. United Nations General Assembly Resolution 70/1, Transforming Our World: the 2030 Agenda for Sustainable Development, A/RES/70/1, (Sep. 25, 2015), supra note 1. 
the study will examine these pronouncements and other sources for guidance on measures to be undertaken to resolve these problems.

\section{(1) The Worldwide Prevalence of Poverty and Inequality}

Jeffrey D. Sachs, Director of the UN Sustainable Development Solutions Network, has characterized a condition of "extreme poverty" as ". . . the inability to meet basic human needs for food, water, sanitation, safe energy, education, and a livelihood. ${ }^{, 567}$ Even in nations where the vast majority of the population is not in a state of extreme poverty, there can still exist very significant pockets of poverty. ${ }^{568}$

The following excerpt (Paragraph 21) has been reproduced from United Nations General Assembly Resolution A/RES/66/288, which was adopted without vote on July 27, 2012:

21. We are deeply concerned that one in five people on this planet, or over 1 billion people, still live in extreme poverty, and that one in seven - or 14 per cent - is undernourished, while public health challenges, including pandemics and epidemics, remain omnipresent threats. .. . ${ }^{569}$

Paragraphs 2 and 4 of the same Resolution (A/RES/66/288) place the issue of poverty eradication in the context of sustainable development:

2. Poverty eradication is the greatest global challenge facing the world today and an indispensable requirement for sustainable development. . . . ${ }^{570}$

567. Id. at 32 .

568. Id. at 32 .

569. U.N. General Assembly Resolution A/RES/66/288 (2012), supra note 17, II 21.

570. U.N. General Assembly Resolution A/RES/66/288 (2012), supra note 17, II 2. 
4. ... We [] reaffirm the need to achieve sustainable development by promoting sustained, inclusive and equitable economic growth, creating greater opportunities for all, reducing inequalities, raising basic standards of living, fostering equitable social development and inclusion, and promoting the integrated and sustainable management of natural resources and ecosystems that supports, inter alia, economic, social and human development. . . . ${ }^{571}$

It is reported that the two major regions of the world most in need of developmental advancement are sub-Saharan Africa and South Asia. ${ }^{572}$ In 2010, an estimated 48.5 percent of the population of tropical sub-Saharan Africa, about 413 million people, lived in extreme poverty. ${ }^{573}$ The corresponding figure for South Asia in the same year was 507 million people. ${ }^{574}$

\section{(a) Issues of Poverty in Africa}

Small farms in sub-Saharan Africa have, on average, produced crop yields significantly lower than those in other developing nations. ${ }^{575}$ A key reason for the diminutive yields is that Africa's farmers have generally lacked the economic resources to keep their farms' soils supplied and replenished with the nitrogen, potassium, and phosphorous necessary for optimal crop yields. ${ }^{\mathbf{5 7 6}}$ Further, African farmers have lacked the means to invest in irrigation systems and high-yield seeds. ${ }^{\mathbf{5 7 7}}$

571. U.N. General Assembly Resolution A/RES/66/288 (2012), supra note 17, para. 4.

572. SACHS, The Age OF Sustainable DeVelopment (2015), supra note 73, at 149.

573. Id.

574. Id.

575. Sachs, The Age Of Sustainable DeVelopment (2015), supra note 73, at 151.

576. Id. at 152 .

577. Id. at 154 . 
In view of the apparent shortages of resources faced by African farmers, it would seem reasonable and proper for African governments to set up State-sponsored programs to assist farmers, particularly small farm owners, to apply for credit or grants, so that they can obtain the resources they need to increase their crop yields. ${ }^{\mathbf{5 7 8}}$

The ending of extreme poverty in Africa will require also a major expansion and upgrading of infrastructure, such as roads, railroad systems, power generation facilities, electricity transmission grids, ports, and communication networks. ${ }^{579}$ These were among the essential infrastructural elements left in a deficient state by the former colonial rulers of the continent when African nations attained their political independence in the twentieth century. ${ }^{\mathbf{5 8 0}}$

A final challenge that many African nations must meet is that of controlling population levels. ${ }^{\mathbf{5 8 1}}$ Africa has a very high fertility rate, estimated at 5.1 children in the period 2010-2015..$^{\mathbf{5 8 2}}$ In 1950, sub-Saharan Africa's population was about 180 million people. $^{\mathbf{5 8 3}}$ In just sixty years, sub-Saharan Africa's population rose to about 900 million, a five-fold increase. ${ }^{\mathbf{5 8 4}}$ Basing its estimate on a moderate decline in the current high fertility rate, the U.N. projects that the population of Africa will reach 3.8 billion by 2100 - a four-fold increase over its level in $2015 .^{\mathbf{5 8 5}}$

578. $\quad I d$

579. Id. at $154-155$.

580. Id.

581. SaChs, The Age of Sustainable DeVelopment (2015), supra note 73, at 157.

582. Id.

583. Id.

584. Id.

585. Id. 
Jeffrey D. Sachs, Director of the UN Sustainable Development Solutions, states in summation that, "[i]n addition to vital investments in agriculture, health education, physical infrastructure, fiber optics, and electrification, Africa will benefit by investing more in the rapid voluntary reduction of today's high fertility rates." ${ }^{\mathbf{5 8 6}}$ He recommends that African governments take appropriate steps to: (a) ensure that girls are enabled to stay in school, at least through the high-school diploma level, so that child marriages are discouraged; (b) convince communities that families do not need to be large simply to ensure survival of some of the children; and (c) ensure that family planning and modern contraceptives are made available to households at low cost. ${ }^{587}$

(b) Issues of Poverty in South Asia

The primary distinguishing feature of South Asia, comprising India, Bangladesh, Bhutan, Nepal, and Pakistan, is the extent of its population relative to its land area. ${ }^{\mathbf{5 8 8}}$ The population density in India has been estimated as being more than 10 times that of the United States. ${ }^{599}$ Among the effects of high population density are that farms in India are small and her cities are extraordinarily crowded. ${ }^{\mathbf{5 9 0}}$

586. Sachs, The Age OF Sustainable DeVelopment (2015), supra note 73, at 159.

587. Id.

588. Sachs, The Age OF Sustainable DeVelopment (2015), supra note 73, at 159.

589. Id. at 160 .

590. Id. 
Notwithstanding issues related to population, India has emerged from the grip of the devastating famines of her past, and has grown relatively rapidly over the past twenty years. ${ }^{\mathbf{5 9 1}}$ It was a great advance in agricultural technology in the 1950s and 1960s, termed "the Green Revolution," that enabled India to avoid the chronic famines of her past, and to advance into a period of sustained economic growth. ${ }^{\mathbf{5 9 2}}$ However, India's population, which was about 400 million in 1950 , had tripled by $2014 .^{\mathbf{5 9 3}}$ The rapid growth in population has had the unfortunate effect of undoing a significant part of India's gains in food production. ${ }^{\mathbf{5 9 4}}$

The eminent agronomist, M.S. Swaminathan, one of the chief architects of India's Green Revolution, has observed that India needs a second Green Revolution, or what he has termed an "Evergreen Revolution." 595 In view of the rising tide of environmental threats faced by the world, it is said that India's second Green Revolution must emphasize increased crop efficiency, in the economical use of water, fertilizer, and other agricultural process inputs. ${ }^{\mathbf{5 9 6}}$

The first Green Revolution used massive quantities of groundwater, a resource now close to depletion at many sites. ${ }^{\mathbf{5 9 7}}$ The first Green Revolution used great amounts of fertilizer, masses of which have polluted India's riverine resources and coastlines. ${ }^{\mathbf{5 9 8}}$ The first Green Revolution did not pay sufficient

591. Id. at 161.

592. Id.

593. Sachs, The Age of Sustainable DeVelopment (2015), supra note 73, at 164.

594. Id.

595. Id. at 167.

596. Sachs, The Age OF Sustainable DeVelopment (2015), supra note 73, at 167.

597. Id. at 167

598. Id. 
attention to long-term climate change, a phenomenon that had not been fully recognized and understood at the time. ${ }^{\mathbf{5 9 9}}$ It has been observed that India's second Green Revolution will need to develop crop varieties that are resilient to heat waves, droughts, floods, and other events that are projected to occur in the future as consequences of human-induced climate change. ${ }^{\mathbf{6 0 0}}$

The nations of South Asia also face continuing challenges arising from issues of gender equality. ${ }^{601}$ Many traditional South Asian cultures do not permit women to work in their labor forces, to own or inherit property, or to manage monetary resources. ${ }^{\mathbf{6 0 2}}$ Girls in these cultures are often left without adequate access to nutrition, health care, and even basic levels of education. ${ }^{603}$ Although South Asia has, in recent periods, achieved significant progress in these areas, major problems of gender-related discrimination remain unresolved. ${ }^{\mathbf{6 0 4}}$

A noteworthy way in which women in rural communities have been empowered in recent decades has been the establishment of "microfinance" institutions, an innovation pioneered in Bangladesh by two NGOs: Grameen Bank (founded by Muhammad Yunus, Nobel Peace Laureate) and Bangladesh Rural Advancement Committee (BRAC) (founded by Sir Fazle Hasan Abed, social entrepreneur and innovator). ${ }^{\mathbf{6 0 5}}$ The NGOs launched microfinance operations,

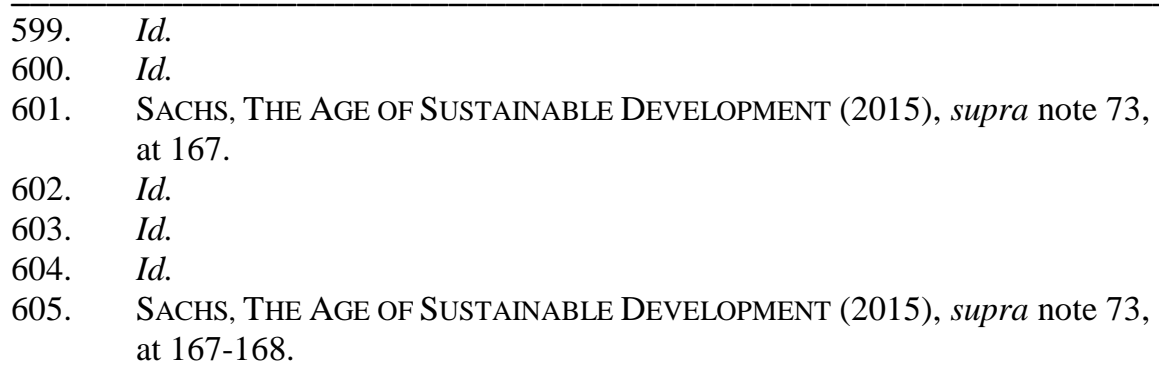


initially, through the efforts of self-help groups, and subsequently through a massive expansion of activities through methods of group lending. ${ }^{\mathbf{6 0 6}}$ The successful results of operations in managing small loans, and in empowering rural women, have caused microfinance to spread throughout the world, as a powerful tool for empowerment at the grassroots level, gender equality, and income generation. ${ }^{607}$

A notable feature of female empowerment is that it has given young women an incentive to marry later, and, thereby, reduce their total fertility. ${ }^{\mathbf{6 0 8}}$ Bangladesh has witnessed a significant decline in the fertility rate of her women. $^{609}$ At the $t$ ime of her emergence as an independent nation, in 1971, Bangladesh's total fertility rate (TFR) was about seven, indicating that for every 1,000 women, there would be 7,000 children. ${ }^{\mathbf{6 1 0}}$ Through the movement for the empowerment of women, supported by microfinance, expanded educational opportunities, and a general lowering of cultural and legal barriers for women, Bangladesh's TFR began to decline very rapidly, and now stands at the so-called "replacement level" of two. ${ }^{611}$

A disturbing aspect of South Asia's poverty has been the chronic undernutrition of children, which has hindered their survival, growth, health, and

606. SaChS, The Age Of Sustainable DeVelopment (2015), supra note 73, at 168.

607. SACHS, THE Age Of Sustainable DeVElopment (2015), supra note 73, at 168-169.

608. SACHS, The Age OF Sustainable DeVelopment (2015), supra note 73, at 169.

609. Id.

610. Id.

611. Sachs, The Age of Sustainable DeVelopment (2015), supra note 73, at 170. 
capacity to learn. ${ }^{\mathbf{6 1 2}}$ High proportions of South Asian children are stunted from inadequate diet, chronic infections by worms and other disease-causing agents, and the lack of access to safe water and latrines to ward off reinfection. ${ }^{613}$ The prevention of stunting and related and similar conditions in children would enable South Asian nations to make much greater progress in primary education. ${ }^{\mathbf{6 1 4}}$ The education systems of the nations of South Asia will benefit greatly from augmented funding, and the introduction of innovative twenty-first-century approaches such as the effective use of information technologies in the classroom and for home study. ${ }^{\mathbf{6 1 5}}$

(c) Official Development Assistance (ODA)

The experiences of sub-Saharan Africa and South Asia indicate that appropriately directed investments in agriculture, health, education, infrastructure, and women's empowerment can help these regions to free themselves from the ancient scourge of poverty. ${ }^{616}$ The problem is, however, that individual nations may be too lacking in resources to take the necessary first steps to rise from conditions of poverty. ${ }^{\mathbf{6 1 7}}$ Official Development Assistance (ODA) was conceived of as a temporary measure to help economically disadvantaged nations to make the crucial early investments needed to attain a state of self-sufficiency. ${ }^{\mathbf{6 1 8}}$

612. Id.

613. Id.

614. Id.

615. Id.

616. SACHS, The AgE OF Sustainable DeVElopment (2015), supra note 73, at 171.

617. Id.

618. Id. at 172 
During the period of the Millennium Development Goals (MDG), ODA played a major role in helping poor nations to control AIDS, malaria, and tuberculosis, and in helping to ensure that mothers are safe in childbirth, and that newborn children can survive the first difficult days of life. ${ }^{619}$

Experience indicates that Official Development Assistance (ODA) can make a significant difference when it is operated on a professional basis for the real purpose of development, and is grounded in accurate diagnoses of the needs of recipient low-income nations. ${ }^{\mathbf{6 2 0}}$ Mr. Jeffrey D. Sachs, Director of the UN Sustainable Development Solutions observes: "[ODA] comes at very low cost, less than 1 percent of the national income of the donor countries. If the rich world makes that effort, and if the funds are well used, ODA indeed can help to ensure that we are the generation that ends extreme poverty."

\section{(2) Summation of Issues of Poverty and Inequality}

Paragraph 19 of U.N. General Assembly A/RES?66/288 concedes "uneven progress" in sustainable development and poverty eradication, and affirms the need for full participation of all countries, in particular developing countries, in global decisionmaking: ${ }^{622}$

619. Id. at 174

620. SACHS, The Age of Sustainable DeVelopment (2015), supra note 73, at 175.

621. Id.

622. U.N. General Assembly Resolution A/RES/66/288 (2012), supra note 17, II 19. 
19. We recognize that the twenty years since the United Nations Conference on Environment and Development in 1992 have seen uneven progress, including in sustainable development and poverty eradication.... We also recognize the need to accelerate progress in closing development gaps between developed and developing countries, and to seize and create opportunities to achieve sustainable development through economic growth and diversification, social development and environmental protection. To this end, we underscore the continued need for an enabling environment at the national and international levels, as well as continued and strengthened international cooperation, particularly in the areas of finance, debt, trade and technology transfer, as mutually agreed, and innovation, entrepreneurship, capacity-building, transparency and accountability.... . In this context, we affirm the continued need for the full and effective participation of all countries, in particular developing countries, in global decision-making.

The emphasis placed by Resolution A/RES/66/288 on the eradication of poverty and inequality on a global scale, as an essential element of sustainable development, is indicative, first, of the importance assigned by the General Assembly to this task in itself. Second, it is affirmation of the Assembly's recognition that the ending of poverty and inequality are inextricably related to other goals of sustainable development, such as economic advancement, protection of the global environment from degradation, and prevention of anthropogenic climate change. 


\section{J. Contestations of Anthropogenic Causes of Climate Change}

Section J of Part II presents the viewpoints of members of the scientific community who contest correlations between human activities and processes, and observed changes in climate.

\section{(1) Contestations of Anthropogenic Causation}

(a) Professor Ian Plimer

Professor Ian Plimer, Emeritus Professor of Earth Sciences at the University of Melbourne, and Professor of Mining Geology at the University of Adelaide, made the following observations in regard to issues of climate change:

1. Only one out of 85,000 molecules in the atmosphere is carbon dioxide $\left(\mathrm{CO}_{2}\right)$ of human origin. In contrast, $32 \mathrm{CO}_{2}$ molecules out of every 85,000 molecules in the atmosphere, are of natural origin. Based on these facts, Professor Plimer expresses doubt in regard to the hypothesis that human-generated $\mathrm{CO}_{2}$ “drives hugely complex climate change systems.",623

2. All six of the great ice ages were initiated when atmospheric $\mathrm{CO}_{2}$ occupied a far higher proportion of the atmosphere than it does at present. ${ }^{\mathbf{6 2 4}}$

3. In the first two ice ages, atmospheric $\mathrm{CO}_{2}$ was up to one thousand times higher than it is at present. ${ }^{\mathbf{6 2 5}}$

623. Ian Plimer, The Science and Politics of Climate Change, in Climate Change: The Facts 12 (Alan Moran ed., 2015).

624. Id.

625. Id. 
(b) Professor Richard S. Lindzen

Dr. Richard S. Lindzen, Atmospheric Physicist, former Professor of Meteorology at the Massachusetts Institute of Technology, and lead author of Chapter 7, "Physical Climate Processes and Feedbacks," of the Intergovernmental Panel on Climate Change's (IPCC's) Third Assessment Report (2001), ${ }^{\mathbf{6 2 6}}$ offers the following assessment of prevailing theories of climate sensitivity and phenomena of extreme weather: ${ }^{627}$

What we have seen is that climate is probably insensitive to increases in greenhouse gases, and that there is little reason to suppose that a warmer world will be notably characterised by storminess and extremes though both are part of normal weather variability. Scientific agreement is largely premised on agreement over trivial issues that are distinct from alarm. ... the acquiescence of science in this abuse is disturbing to say the least.

\section{(c) Professor Garth W. Paltridge}

Professor Garth W. Paltridge, Emeritus Professor at the Institute of Antarctic and Southern Oceans Studies (IASOS), University of Tasmania, has pointed to prevailing uncertainties in climate modeling in regard to clouds, and in regard to the role of oceans in modulating climate change: ${ }^{\mathbf{6 2 8}}$

1. Clouds are important mediators of the balance between the processes of solar heating and infrared cooling of the Earth. The distances between measure-

626. Climate Change 2001 - IPCC Third Assessment Report, INTERGOVERNMENTAL PANEL ON CLIMATE CHANGE, IPCC, https://www.ipcc.ch/ipccreports/tar/ (last visited Mar. 12, 2017).

627. Richard S. Lindzen, Global Warming, Models and Language, in ClimATE CHANGE: THE FACTS 55-56 (Alan Moran ed., 2015).

628. Garth W. Paltridge, Uncertainty, Scepticism and the Climate Issue, in ClimATE CHANGE: THE FACTS 146-154 (Alan Moran ed., 2015). 
ment points of a worldwide climate grid used by climate modelers in their calculations, exceed the dimensions of typical clouds, leading to the need for guesswork in the assessment of the states of key attributes of clouds. The inaccuracies deriving from shortcomings in the representation of clouds in climate models have led to amplifications of the order of about three (3) in forecasts of warming of the Earth from increasing levels of carbon dioxide.

2. Oceans are the primary reservoirs of heat in the Earth's climate system. Oceans have internal "more-or-less" random episodes of change on timescales ranging from years through centuries, which cause changes in surface temperature that affect the Earth's overall climate. Oceanic fluctuations between measurement points of the global grid used by climate modelers can, as with clouds, cause serious errors in forecasts based on such models.

In light of the uncertainties involved, Professor Paltridge has observed that, "the chances of proving, in the "hard scientific sense," that change of climate over the next century will be large enough to be disastrous are virtually nil."${ }^{, 629}$ He added: "The same uncertainty ensures that the chances of a climate sceptic, or anyone else for that matter, proving the disaster theory to be oversold, are also virtually nil., ${ }^{, 630}$

629. Id. at 151.

630. Id. 
(d) Patrick J. Michaels

Mr. Patrick J. Michaels, Director of the Center for the Study of Science at the Cato Institute, Washington DC, made the following observations in regard to hypothesis-testing of ensemble climate models presented in the 2013 report of the Intergovernmental Panel for Climate Change (IPCC): ${ }^{\mathbf{6 3 1}}$

1. The results of an ensemble of climate models used in the 2013 IPCC Report were found to fail when tested against global surface temperature trends.

2. Retrospective hypothesis testing of IPCC model results over a period of 37 years, has indicated failures of IPCC model results.

3. Estimates based on largely independent techniques have indicated that temperature sensitivity (defined as global temperature response to doubling in volume of carbon dioxide) is lower than the mean in the model ensemble used in the 2013 IPCC report.

\section{(e) Kesten C. Green and J. Scott Armstrong}

Based on hypothesis testing of climate forecasting models, including particularly those of the IPCC, Mr. Kesten C. Green, Senior Research Associate of the Ehrenberg-Bass Institute, University of South Australia, and Mr. J. Scott Armstrong, University of Pennsylvania, made the following observations in their article, "Forecasting Global Climate Change:",632

631. ' Patrick J. Michaels, Why climate models are failing, in Climate Change: THE FACTS 26- 37 (Alan Moran ed., 2015).

632. Kesten C. Green \& J. Scott Armstrong, Forecasting global climate change, in CLIMATE CHANGE: THE FACTS 186 (Alan Moran ed., 2015). 
We found that there are no scientific forecasts that support the hypothesis that man-made global warming will occur. Instead, the best forecasts of temperatures on Earth and beyond are derived from the hypothesis of persistence. Specifically, we forecast that lobal average temperatures will trend neither up nor down, but will remain within $0.5^{\circ} \mathrm{C}\left(1^{0} \mathrm{~F}\right)$ of the 2013 average for the twenty-first century.

\section{(2) Summation of Contestations of Anthropogenic Causation}

Viewpoints contesting anthropogenic causes of climate change have been presented in the foregoing material in order to highlight the need for urgent efforts to bring about general worldwide consensus in these matters.

\section{K. $\underline{\text { Conclusion }}$}

At a U.N. special summit in September 2015, world leaders articulated an ambitious plan encompassing a set of 17 goals and 169 targets to end poverty, reduce inequalities, and protect the environment. The leaders' new plan came into effect on January 21, 2016, effectively replacing the Millennium Development Goals ("MDGs"). ${ }^{\mathbf{6 3 3}}$ The "New Universal Agenda" was proclaimed to be aimed at realizing "the human rights of all," and its provisions were declared to "balance the three dimensions of sustainable development: the economic, social and environmental.,

The Fifth Report of the Intergovernmental Panel on Climate Change (IPCC), first published in 2015, stated that there is clear evidence of the impact of

633. United Nations General Assembly Resolution A/RES/70/1 (2015), supra note 1.

634. Id. at Preamble II 3. 
human activity on the Earth's climate system. ${ }^{635}$ Significant concerns of fairness are implicated in regard to "Small Island Developing States" (SIDS), and other developing coastal states, since such states contribute little to the global threat of climate change, and yet will bear a disproportionate share of the burden of climate change. ${ }^{\mathbf{6 3 6}}$ The IPCC, indicates that adaptation options exist in all sectors, but cautions that their context for potential to reduce climate-related risks, differs across sectors and regions. ${ }^{637}$

The issues of water are inextricably interrelated with those of climate change, ecosystems, the disposal of hazardous substances, and pollution factors such as contamination, excessive consumption, and uneven distribution of supply sources have led to situations of water scarcity, aquifer depletion, and damage to ecosystems. ${ }^{\mathbf{6 3 8}}$

A significant cause of the species extinction currently reported to be in progress, has been identified as human activity that has resulted in native habitat destruction, species invasions, pollution, population growth and overexploitation of natural resources. ${ }^{639}$ Conservation, restoration, and reconciliation have been indicated as approaches for maintaining the health of ecosystems and habitats. ${ }^{\mathbf{6 4 0}}$

Pollutants can be derived from natural sources such as volcanic eruptions; from organic sources such as sewage; and from synthetic chemicals produced by

635. IPCC, 2014: Climate Change 2014: Synthesis Report, supra note 147, at 40.

636. Powers, supra note 145, at 166

637. IPCC, 2014: Climate Change 2014: Synthesis Report, supra note 147, at 95.

638. See supra text accompanying notes 257-282.

639. See supra text referenced by notes 294-320.

640. See supra text referenced by notes 321-357. 
human activity. ${ }^{641}$ Pollution remediation involves evaluating, halting, and reversing damage to environmental systems caused by pollution. ${ }^{642}$ The "Precautionary Principle," one of 27 principles stated in the Rio Declaration of 1992, advocates precautionary measures, even in situations in which dangerous relationships have not been established with complete scientific certainty. ${ }^{643}$

There are significant risks of pollution and environmental degradation associated with the extraction, transportation, and use of fossil fuels. ${ }^{\mathbf{6 4 4}}$ Further, worldwide discoveries of petroleum were reported to have reached a peak in 2005, with successive new fields declining steadily in size. ${ }^{645}$ Analysts project that, even if sources of renewable energy develop rapidly, it will require decades to achieve a transition to a carbon-free economy worldwide. ${ }^{\mathbf{6 4 6}}$

The emphasis placed by Resolutions A/RES/66/288 and A/RES/70/1 on the eradication of poverty and inequality on a global scale, as an essential element of sustainable development, is indicative of the importance assigned by the General Assembly to this task in itself. Further, it is indicative of the Assembly's recognition that the ending of poverty and inequality are inextricably related to other goals of sustainable development, such as economic advancement, protection of the global environment from degradation, and prevention of anthropogenic climate change.

641. ROBERTSON, supra note 47 , at 135.

642. See supra text accompanying notes 414-418.

643. See supra text accompanying notes 430-431.

644. ROBERTSON, supra note 47, at 161.

645. Id. at 163 .

646. Id. at 179 ,

(citing Ayres, Robert U. \& Edward H. Ayres, Crossing the Energy Divide, at 1

(Philadelphia: Wharton School Publishing (2010)). 


\section{HUMAN RIGHTS \& SUSTAINABLE DEVELOPMENT}

\section{A. $\underline{\text { Introduction }}$}

Part III of this study traces the origins of the modern concept of human rights to the adoption by the United Nations General Assembly of the Universal Declaration of Human Rights (UDHR) in 1948, followed subsequently by the promulgation in 1966, of the International Covenant on Economic, Social, and Cultural Rights (ICESCR) and the International Covenant on Civil and Political Rights (ICCPR). ${ }^{647}$ The study emphasizes the legal obligation imposed by the United Nations Charter upon the U.N. Organization and its Member States, to preserve and promote human rights. ${ }^{\mathbf{6 4 8}}$ It presents the positions of Amnesty International and Human Rights Watch (HRW) on the symbiotic relationship between human rights and protection of the environment. ${ }^{\mathbf{6 4 9}}$

The study then proceeds to an examination of U.N. General Assembly Resolution A/RES/70/1, with its seventeen Sustainable Development Goals (SDGs). ${ }^{650}$ It presents arguments that the goals of the Resolution encompass legally cognizable human rights, grounded in provisions of the U.N. Charter and the International Bill of Human Rights, and informed by provisions of other major instruments. $^{651}$ It critically evaluates provisions of the SDGs of Resolution A/RES/70/1. ${ }^{62}$ Finally, it concludes with a summation of the themes of Part III.

647. See infra notes 713-721.

648. See infra notes 722-732.

649. See infra notes 746-763.

650. United Nations General Assembly Resolution A/RES/70/1, supra, note 1.

651. See infra notes 773-892.

652. See infra notes 893-943. 


\section{B. Human Rights - the Foundations}

Rights are conditions of social life that enable the realization of certain vital human potentialities. In a fundamental sense, rights are not creations of political States. States can only recognize rights. However, it has been the infallible lesson of history that States that fail to recognize and respect fundamental rights, do not survive for long.

"Human rights are rights inherent to all human beings, regardless of race, sex, nationality, ethnicity, language, religion, or any other status." "653 "Human rights include the right to life and liberty, freedom from slavery and torture, freedom of opinion and expression, the right to work and education, and many more. Everyone is entitled to these rights, without discrimination. ${ }^{.654}$

The catastrophic events of World War II led to a program of increased protection of human rights and fundamental freedoms at the international level. Among the early steps undertaken in the process included the adoption by the United Nations General Assembly of the Universal Declaration of Human Rights (UDHR), followed subsequently by the promulgation of the International Covenant on Economic, Social, and Cultural Rights (ICESCR) and the International Covenant on Civil and Political Rights (ICCPR). ${ }^{655}$

653. United Nations, Human Rights, https://www.un.org/en/sections/issues-depth/human-rights/ (last visited: Jun 2, 2019).

654. Id.

655. JAMES CRAWFORD, BROWNLIE'S PRINCIPLES OF PUBLIC INTERNATIONAL LAW, 634- 636 (7th ed. 2008); Universal Declaration of Human Rights (UDHR); International Covenant on Economic, Social, and Cultural Rights (ICESCR); International Covenant on Civil and Political Rights (ICCPR); supra note 9. 


\section{The UDHR, ICESCR, and ICCPR}

In 1948, the General Assembly of the United Nations adopted the highly influential Universal Declaration of Human Rights (UDHR), which is not a treaty, but whose provisions reflect general principles of the law, and elementary considerations of

humanity. ${ }^{656}$ The UDHR stated rights whose protection would be clarified and amplified by later instruments. ${ }^{657}$

In 1966, the Third Committee of the General Assembly of the United Nations adopted two Covenants and a Protocol: the International Covenant on Economic, Social, and Cultural Rights (ICESCR); the International Covenant on Civil and Political Rights (ICCPR); and an Optional Protocol to the latter. ${ }^{658}$ In 1989 a Second Protocol to the ICCPR was adopted, aimed at the abolition of the death penalty; and in 2008, an Optional Protocol to the ICESCR, relating to the processing of individual communications. ${ }^{\mathbf{6 5 9}}$

The Covenants, which came into force in 1976, have legal effect as treaties in respect to contracting parties, and constitute a detailed, adjudicative codification of human rights. ${ }^{\mathbf{6 0 0}}$ The ICESCR binds each party to steps, to the maximum of its available resources, with a view to achieving progressively the full realization of the rights recognized in the Convention by all appropriate means. ${ }^{\mathbf{6 6 1}}$ Supervisory machinery places

656. JAMES CRAWFORD, BROWNLIE'S PRINCIPLES OF PUBLIC INTERNATIONAL LAW (7th ed. 2008) at 634- 636.

657. Id.

658. JAMES CRAWFORD, BROWNLIE'S PRINCIPLES OF PUBLIC INTERNATIONAL LAW, (7th ed. 2008), at 638.

659. Id.

660. Id. at 638-639.

661. Id. 
upon parties the obligation to submit reports to the Economic and Social Council (ECOSOC) on progressive and corrective measures adopted. ${ }^{\mathbf{6 6 2}}$ The ICCPR is more specific than the ICESCR in its identification of rights, stronger in its statement of the obligation placed on parties to respect rights, and better equipped with mechanisms of supervision. ${ }^{663}$ Contracting parties are required to submit to the Human Rights Council (HRC) reports on measures taken to give effect to the realization of rights mandated by the ICCPR.

\section{The U.N. Charter \& Legal Obligations to Preserve \& Promote Human Rights}

Mr. Hersch Lauterpacht, distinguished jurist, eminent practitioner of international law, and judge of the International Court of Justice (1955-1960), made the following statement in regard to the status of fundamental human rights affirmed by the Charter of the United Nations:

The Charter of the United Nations is a legal document; its language is the language of law, of international law. In affirming repeatedly the 'fundamental human rights' of the individual it must of necessity be deemed to refer to legal rights - to legal rights recognised by international law and independent of the law of the State. ${ }^{64}$

Article 1(3) of the U.N. Charter states that one of the purposes of the United Nations is " $[\mathrm{t}] \mathrm{o}$ achieve international co-operation in solving international problems of an economic, social, cultural, or humanitarian character, and in promoting and encouraging respect for human rights and fundamental freedoms for all . . . ...,665

662. Id.

663. Id.

664. HERSCH LAUTERPACHT, INTERNATIONAL LAW AND HUMAN RIGHTS 34 (1968 ed ) 1950.

665. U.N. CHARTER art. 1(3). 
Article 55(c) of the U.N. Charter states: “ . . . the United Nations shall promote: ... universal respect for, and observance of, human rights and fundamental freedoms for all without distinction as to race, sex, language, or religion." 666 By Article 56, "[a]11 Members pledge themselves to take joint and separate action in cooperation with the Organization for the achievement of the purposes set forth in Article 55.",667

Each Member State of the United Nations, by becoming a party to the Charter, has accepted legal obligations in the effort to promote universal respect for, and observance of, human rights and fundamental freedoms for all without distinction as to race, sex, language, or religion. The term "pledge" in Article 56 clearly indicates that Member States have accepted an international obligation for objectives specified in Article 55. ${ }^{668}$

Mr. Lauterpacht, made the following statement in regard to the scope and magnitude of legal obligations to promote the observance of human rights, mandated by the Charter of the United Nations: "The provisions of the Charter . . impose legal obligations not only upon the Members of the United Nations. They imply a comprehensive legal obligation upon the United Nations as a whole., ${ }^{\mathbf{6 6 9}}$

665. U.N. CHARTER art. 1(3).

666. U.N. CHARTER art. 55(c).

667. U.N. CHARTER art. 56.

668. See generally Schwelb, The International Court of Justice and the Human Rights Clauses of the Charter, 65 AM. J. INT'L L. 337 (1972).

669. LAUTERPACHT, supra note 664, at 159. 
He observed that the provisions of the Charter lay down that the United Nations shall promote "universal respect for, and observance of, human rights and fundamental freedoms" (Article 55(c)). ${ }^{670} \mathrm{He}$ conceded that the phraseology - "the United Nations shall promote" - applies also to other objects of the Economic and Social Council. ${ }^{671} \mathrm{He}$ contended, however, that ". . . the degree of legal obligation is particularly high with regard to a subject matter which, as in the case of human rights and fundamental freedoms, is a constant and fundamental theme of the Charter. There is laid down here a clear duty of collective action" ${ }^{\text {672 }}$ Mr. Lauterpacht concluded his exegesis as follows:

It is an inescapable principle of interpretation that whenever an international instrument defines, in its constitution, the purposes of its being, the right and obligation to give effect to those purposes are inherent in it and nothing short of an express derogation from that implicit authority can legitimately restrict the powers and obligations in question. ${ }^{673}$

. . . Finally, one of the results of the provisions of the Charter in the matter of human rights and fundamental freedoms is to effect a far-reaching change in the position of the individual in international law. If these provisions of the Charter constitute legal rights and obligations, then they signify the recognition, in an international treaty of wide generality, of rights of the individual as such. They transfer the inalienable and natural rights of the individual from the venerable but controversial orbit of the law of nature to the province of positive law, of international law. They thus mark a significant step towards the recognition of the individual as a subject of the law of nations.

.. . They are not accompanied by the full conferment of international procedural capacity upon the individual to enable him to enforce, in his own right and in the judicial sphere, the legal benefits of the status thus acquired. But their silence on the subject does not imply a denial of any capacity whatsoever to vindicate his rights before international organs.

670. Id.

671. Id.

672. LAUTERPACHT, supra note 664, at 159.

673. Id. 
On the contrary, such capacity will be determined not by any preconceived notions on the question whether the individual can under international law derive rights under treaties and enforce them in his own name, but by the degree to which the United Nations and its organs will assume the function of translating into reality the provisions of the Charter. ${ }^{674}$

Mr. Lauterpacht's pronouncement has direct relevance to the first objective of the present study, which is stated as follows: “. . . [P]resent arguments that the ramework of Sustainable Development encompasses legally cognizable human rights, grounded in provisions and principles of the U.N. Charter and the International Bill of Human Rights . . ." A direct result of such a demonstration would, under the rule stated in Mr. Lauterpacht's exposition, be to impose legal obligations upon the Members of the United Nations, and a comprehensive legal obligation upon the United Nations as a whole, in regard to the provisions of the framework of Sustainable Development as stated in U.N. General Assembly Resolution A/RES/70/1 (Transforming our world: the 2030 Agenda for Sustainable Development). ${ }^{\mathbf{6 7 5}}$

\section{The Protection of the Environment as a Human Right}

Economic and social human rights have been explicitly identified in the Universal Declaration of Human Rights, and codified as such in the International Covenant on Economic and Social Rights. Of the three dimensions of the framework of Sustainable Development, only the constituent concerned with environmental protection has not been explicitly identified as encompassing

674. Id. at $159-160$.

675. United Nations General Assembly Resolution A/RES/70/1, supra, note 1. 
human rights in the International Bill of Human Rights. The material in this section of the study, will, accordingly, present findings on the issue by major human rights bodies.

Human rights bodies have identified three categories of obligations assignable to States for protection against environmentally related interference with human rights. ${ }^{\mathbf{6 7 6}}$ These obligations include procedural duties, substantive duties, and duties relating to the protection of communities particularly vulnerable to environmental harm. ${ }^{677}$

First, human rights law imposes procedural obligations on states, including duties to evaluate and publicize environmental impacts on human rights, to facilitate public participation in environmental decision-making, and to provide access to effective legal remedies for environmental harm to the enjoyment of human rights. ${ }^{\mathbf{6 7 8}}$ The preservation of rights of freedom of expression and association are of particular importance to the protection of environmental advocates, who are often at risk of harassment and death. ${ }^{679}$

States must not only refrain from violating the rights of free expression and association directly; they must also take steps to protect the life, liberty, and security of individuals exercising those rights. ${ }^{\mathbf{6 8 0}}$

676. John H. Knox, Human Rights, Environmental Protection, and the Sustainable Development Goals, 24 Wash. Int'l L.J. 517 (2015), supra note 6, at 521.

677. Id.

678 John H. Knox, UN Special Rapporteur, Mapping Report - 2014, supra note 16, IIII 29 - 43.

679. John H. Knox, Human Rights, Environmental Protection, and the Sustainable Development Goals, 24 Wash. Int'l L.J. 517 (2015), supra note 6, at 521, (citing from the following: DEADLY ENVIRONMENT, https://www.globalwitness.org/en/campaigns/environmentalactivists/deadly-environment/ (last visited Jul. 28, 2017)).

680 John H. Knox, UN Special Rapporteur, Mapping Report-2014, supra note 16, III $39-40$. 
These obligations have been held to apply to environmental defenders as strongly as they apply to other human rights defenders. ${ }^{\mathbf{6 8 1}}$ The UN Human Rights Commission emphasized these obligations when, in 2003, it called upon states, "to take all necessary measures to protect the legitimate exercise of everyone's human rights when promoting environmental protection and sustainable development." ${ }^{682}$

Second, evolving environmental human rights jurisprudence indicates that, in addition to procedural duties, States have substantive obligations to protect against environmental harm that derogates from the enjoyment of human rights. ${ }^{683}$ The character and weight of these obligations are dependent on the rights at issue. ${ }^{64}$ But human rights bodies are in general agreement that human rights law grants States the discretion to strike a reasonable balance, in each case, between environmental protection and other issues of magnitude, such as economic development. ${ }^{685}$ In evaluating whether the balance struck by a State is reasonable, human rights bodies have looked at factors such as whether the State's actions comply with international health and environmental standards, whether the actions are nonretrogressive, and whether the State actually implements the balance in practice. ${ }^{\mathbf{6 8 6}}$

681. John H. Knox, Human Rights, Environmental Protection, and the Sustainable Development Goals, 24 Wash. Int'l L.J. 517 (2015), supra note 6, at 521.

682. John H. Knox, Human Rights, Environmental Protection, and the Sustainable Development Goals, 24 Wash. Int'l L.J. 517 (2015), supra note 6, at 522, (citing U.N. Commission on Human Rights, Res. 2003/71: Human Rights and the Environment as Part of Sustainable Development, 62nd Meeting,, U.N. Doc. E/CN.4/RES/2003/71, II 4 (Apr. 25, 2003)).

683. John H. Knox, Human Rights, Environmental Protection, and the Sustainable Development Goals, 24 Wash. Int'l L.J. 517 (2015), supra note 6, at 522.

684. Id.

685. Id.

686. Id. 
Third, human rights bodies have identified special obligations of States in respect to sections of their populations who are especially vulnerable to environmental harm. ${ }^{\mathbf{6 8 7}}$ In addition to a general prohibition on discrimination by States in the application of their environmental laws and policies, the sources have specified additional duties owed to certain vulnerable communities, including, in particular, indigenous peoples, whose close relationships with the environment imply that their rights are particularly susceptible to infringement as a result of environmental degradation. ${ }^{\mathbf{6 8 8}}$ In an illustrative case, Saramaka People v.Suriname (Nov. 28, 2007), ${ }^{\mathbf{6 8 9}}$ the Inter-American Court of Human Rights declared that, with respect to large-scale development projects that would have a major impact within the territory of a tribal people, the government must obtain "their free, prior, and informed consent, according to their customs and traditions."

687. Id.

688. Id. at 522-523.

689. Saramaka People v. Suriname, Int-Am. Ct. H.R. (Ser. C) No. 172, 1134 (Nov. 28, 2007).

690. John H. Knox, Human Rights, Environmental Protection, and the Sustainable Development Goals, 24 Wash. Int'l L.J. 517 (2015), supra note 6, at 523. 
The Mapping Report developed by John H. Knox, U.N. Special

Rapporteur, in response to the mandate issued by the Human Rights Council in $2012,{ }^{691}$ identified areas where the human rights obligations relating to environmental harm are less developed. ${ }^{692}$ The most notable of these involve interference with the enjoyment of human rights caused by transboundary environmental harm. ${ }^{63}$ While it is difficult to reach firm conclusions as to the application of human rights obligations to transboundary harm, it does seem clear that, at a minimum, States are obliged to cooperate with one another to address international human rights challenges such as climate change. ${ }^{\mathbf{6 9}}$

\section{Amnesty International: Environmental Factors and Human Rights}

The position of Amnesty International on the relationship between problems of climate change and issues of human rights, was stated in 2015 by Mr. Savio Carvalho, Senior Advisor on International Development and Human Rights. $^{695}$ In a statement made in London on December 1, 2015, Mr. Carvalho addressed the following issues: ${ }^{\mathbf{9 9 6}}$

Climate change is one of the greatest human rights challenges of the time. ${ }^{697}$ Extreme weather-related disasters and rising seas will destroy homes and

691 John H. Knox, UN Special Rapporteur, Mapping Report-2014, supra note 16.

692. John H. Knox, Human Rights, Environmental Protection, and the Sustainable Development Goals, 24 Wash. Int'1 L.J. 517 (2015), supra note 6, at 523.

693. Id.

694. Id.

695. AMNESTY INTERNATIONAL

https:/www.amnesty.org/en/latest/campaigns/2015/12/climate-change-human-rights/

696. Id. last visited April 29, 2017).

697. Id. 
ruin people's ability to earn a living. ${ }^{698}$ Unless emissions are reduced significantly, an estimated 600 million people are likely to experience drought and famine. ${ }^{699}$ There are, therefore, direct linkages between climate change and such basic human rights as the rights to life, health, food, water and housing. ${ }^{\mathbf{7 0 0}}$

Across the world, women form the majority of self-employed, small-scale farmers. ${ }^{701}$ They will, therefore, be first and most severely affected by droughts, floods and crop failures. ${ }^{\mathbf{7 0 2}}$ They are also more likely to take on the burden of collecting water, and so, will be acutely affected by severe water shortages. ${ }^{\mathbf{7 0 3}}$ Indigenous Peoples are often most affected by situations of global warming, because of their dependence on the environment. ${ }^{\mathbf{7 0 4}}$ Many live in fragile ecosystems that are highly sensitive to changes in climate. ${ }^{\mathbf{7 0 5}}$ This situational relationship threatens their cultural identity, which is closely linked to their traditional land and livelihoods. ${ }^{706}$ As famines, droughts and natural disasters become more frequent, it is foreseeable that the numbers of people crossing international borders will increase. ${ }^{707}$ While not all such people will be legally classifiable as "refugees," they should still be entitled to support from States most

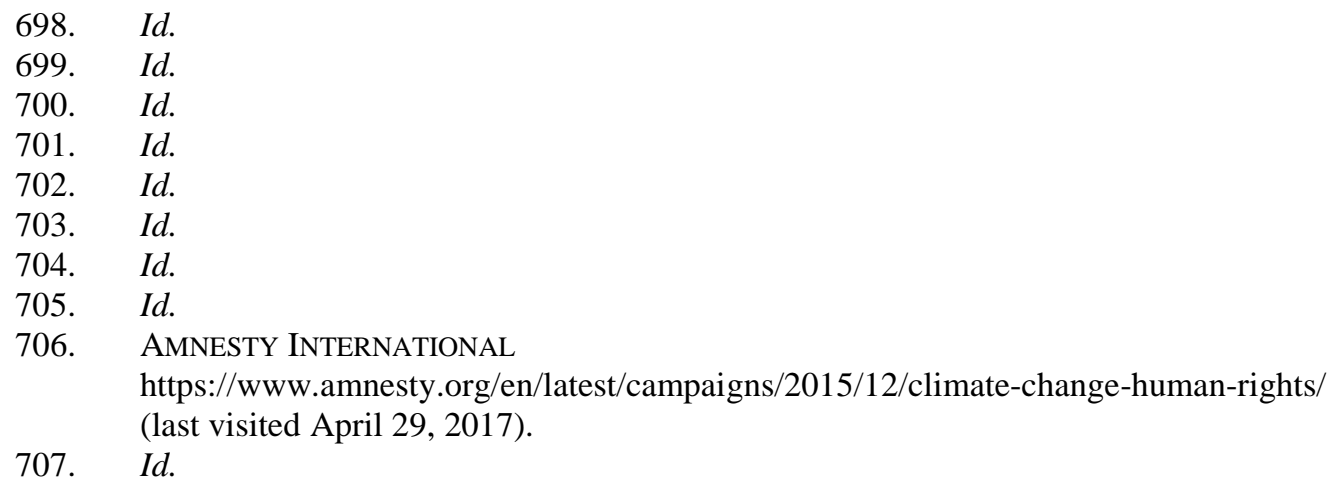


responsible for climate change. ${ }^{\mathbf{7 0 8}}$

In his address on behalf of Amnesty International, Mr. Savio Carvalho summarized the following findings to be noted, and actions to be undertaken in mitigation of adverse effects of climate change: ${ }^{709}$

1. It is quite possible that climate change can lead to wars in regard to issues such as competition over natural resources.

2. Governments must do all they can to reduce carbon emissions, including the phasing out of subsidies for fossil fuels. Governments must also help people adapt to climate change, and provide compensation, for example, to those who have lost their homes because of rising sea levels.

Amnesty International, in association with partners, is pressing governments and institutions like the United Nations to take concrete and urgent actions on climate change. Such steps are not motivated by concerns of charity or aid; in essence, they are about human rights and justice.

2. Human Rights Watch (HRW): Environmental Factors and Human Rights

The position of Human Rights Watch (HRW) on the relationship between problems of climate change and issues of human rights, was expressed in the following submission by HRW on December 22, 2016 to the Office of the United

708. Id.

709. Id. 
Nations High Commissioner for Human Rights (OHCHR): ${ }^{\mathbf{7 1 0}}$

- Millions of children around the world suffer violations of their rights because of flawed and inadequate governmental responses to environmental degradation and climate change. Children from indigenous communities, those facing caste-based discrimination, and girls, are often particularly at risk. HRW has documented some of these issues through fact-finding investigations in Bangladesh, Kenya, and Malawi.

- National environmental and climate change laws and policies, and international environmental agreements have long neglected to follow an approach that adequately recognizes human rights issues. The Paris Agreement adopted by States parties of the United Nations Framework Convention on Climate Change (UNFCCC), however, takes a more integrated approach to human rights and environmental issues.

- The United Nations Children's Fund (UNICEF), Child Rights organizations, and the UN Special Rapporteur on Human Rights and the Environment have recently highlighted the extremely harmful impacts of climate change on the environment and expressed concern over the ability of governments to protect the rights of children.

710. HumAN Rights WATCH Submission on Climate Change and Child Rights to the OHCHR DECEMBER 22, 2016 5:46AM EST https://www.hrw.org/news/2016/12/22/submission-climate-change-andchild-rights-ohchr (last visited April 29, 2017). 
- In 2016, the Committee on the Rights of the Child, in its Concluding Observations to the United Kingdom, expressed concern in regard to the "high level of air pollution that directly affects child health" and "contributes to the negative impact of climate change affecting various rights of the child," both domestically and in other countries.

- In the Turkana region of Kenya, Human Rights Watch found that climate change has limited local indigenous communities' access to food and clean water. As a result, many children have become sick. Girls often walk extremely 1 ong distances to dig for water in dry riverbeds, exposing themselves to dangers along the route. Climate change has modified the behavior of mosquitoes and ticks that transmit diseases such as malaria.

- In Bangladesh, Human Rights Watch (HRW) has documented instances of families arranging child marriages for their daughters under 18 because of extreme poverty, compounded by natural disasters that were exacerbated by climate change.

- In Malawi, the government's failure to address the hazards from coal mining has compromised children's rights to health, food, water, and housing. In some of Malawi's coal mining areas, residents informed HRW representatives that they and their children suffered from increasing rates of illnesses that could be related to mining practices.

Human Rights Watch (HRW) made the following recommendations to governments and relevant organizations, on issues related to climate change: 
Governments should: ${ }^{711}$

- Incorporate child rights analysis and policy measures in all climate change mitigation and adaptation strategy and policy documents, including Nationally Determined Contributions and National Adaptation Communications to the UNFCCC. They should also incorporate an analysis of climate change impacts in reports submitted to human rights treaty bodies including the Committee on the Rights of the Child.

- Consult with children's rights organizations and youth organizations while formulating such planning documents.

- Effectively monitor child rights in the context of climate change to address possible violations and conduct human rights risk assessments to identify children and their communities that are particularly vulnerrable to the impacts of climate change.

- Effectively monitor children's environmental health, including the impacts of air pollution and climate change, for example through air monitoring and other measures.

- Ensure that human rights and environmental impact assessments in the context of climate change are easily and readily available and accessible

- to the public including children, including by providing short summaries in non-technical language; translating the summaries and the full reports into local languages; posting them on the internet; providing copies in public buildings including local schools; and holding information sessions in directly affected communities.

The UNFCCC Secretariat should: ${ }^{712}$

- Coordinate with UN Women regarding climate change impacts and their effect on girls and strategies to mitigate them.

- Work with UNICEF and the UN Population Fund to ensure that attention to climate change is incorporated into the global work that these two agencies are leading on ending child marriage.

\section{E. Summation of Issues of Human Rights}

The evolution of the concept of human rights includes the recognition that these rights are secured by obligations of States to protect against environmentally

711. Id.

712. Id. 
related harm. Human rights bodies have identified three categories of obligations attributable to States for protection against environmentally related interference with human rights. These obligations include procedural duties, such as the duty to facilitate public participation in environmental decision-making; substantive duties to protect against environmental harm that causes derogation from the enjoyment of human rights; and duties relating to the protection of groups and communities particularly vulnerable to environmental harm.

A report (“Mapping Report”) prepared by John H. Knox, U.N. Special Rapporteur, in response to a mandate issued by the Human Rights Council in 2012, identified areas where the human rights obligations relating to environmental harm are comparatively less developed. The most notable of these involve interference with the enjoyment of human rights caused by transboundary environmental harm. However, it seems clear that, at a minimum, States are obliged to cooperate with one another in endeavors to address international human rights challenges such as those involved in climate change.

Amnesty International (“Amnesty”) and Human Rights Watch (HRW) emphasize the close relationship that exists between basic human rights and the right to live and work in an environment and climate free of degradation. Both organizations point to the likelihood that events triggered by climate change, such as extreme weather-related disasters and rising seas, will destroy homes and ruin people's ability to earn a living. Both entities indicate the acute vulnerability in such situations of women, children, and members of 
indigenous communities and other disadvantaged groups.

Amnesty International and HRW urge upon governments and international organizations the responsibility to do all they can to reduce carbon emissions, including the phasing out of subsidies for fossil fuels; help people adapt to climate change; and provide compensation, for example, to those who have lost their homes because of rising sea levels. The organizations urge that governments and institutions such as the United Nations take substantive and urgent action on problems of climate change.

\section{F. The Substantive Content of the Sustainable Development Goals (SDGs)}

\section{U.N. General Assembly Resolution A/RES/70/1}

The seventeen goals, which form the core of United Nations General Assembly Resolution A/RES/70/1 (Transforming our world: the 2030 Agenda for Sustainable Development), and which are declared to be integrated and indivisible, and to balance the three dimensions of sustainable development, the economic, social and environmental, are as follows: ${ }^{713}$

Goal 1. End poverty in all its forms everywhere

Goal 2. End hunger, achieve food security and improved nutrition and promote sustainable agriculture

Goal 3. Ensure healthy lives and promote well-being for all at all ages Goal 4. Ensure inclusive and equitable quality education and promote lifelong learning opportunities for all Goal 5. Achieve gender equality and empower all women and girls Goal 6. Ensure availability and sustainable management of water and sanitation for all

713. U.N. General Assembly Resolution A/RES/70/1, Goals 1-17, 
supra, note 1.

Goal 7 Ensure access to affordable, reliable, sustainable and modern energy for all

Goal 8. Promote sustained, inclusive and sustainable economic growth, full and productive employment and decent work for all

Goal 9. Build resilient infrastructure, promote inclusive and sustainable industrialization and foster innovation

Goal 10. Reduce inequality within and among countries

Goal 11. Make cities and human settlements inclusive, safe, resilient and sustainable

Goal 12. Ensure sustainable consumption and production patterns

Goal 13. Take urgent action to combat climate change and its impacts

Goal 14. Conserve and sustainably use the oceans, seas and marine resources for sustainable development

Goal 15. Protect, restore and promote sustainable use of terrestrial ecosystems, sustainably manage forests, combat desertification, and halt and reverse land degradation and halt biodiversity loss Goal 16. Promote peaceful and inclusive societies for sustainable development, provide access to justice for all and build effective, accountable and inclusive institutions at all levels

Goal 17. Strengthen the means of implementation and revitalize the Global Partnership for Sustainable Development

The material that follows presents arguments that that the Sustainable Development Goals (SDG's) of U.N. General Assembly Resolution A/RES/70/1 encompass legally cognizable human rights, grounded in provisions and principles of the U.N. Charter ${ }^{714}$ and International Bill of Human Rights, ${ }^{715}$ and informed by provisions and principles of other major instruments and declarations.

714. U.N. CHARTER.

715. The International Bill of Human Rights

A. Universal Declaration of Human Rights (UDHR);

B. International Covenant on Civil and Political Rights (ICCPR);

C. International Covenant on Economic, Social, and Cultural Rights (ICESCR); supra note 4. 


\section{$\underline{\text { Analysis of Content of Goal } 1}$}

Goal 1 of U.N. General Assembly Resolution A/RES/70/1 states the following: "End poverty in all its forms everywhere."716 The targets of Goal 1 include the ending, by 2030 , of extreme poverty, with social protection systems for all, and substantial coverage of the poor and vulnerable. ${ }^{717}$ Further, these targets seek to ensure, by 2030 , equal access to economic and other basic resources, particularly for the poor and vulnerable; reduction of exposure of the poor and vulnerable to climate-related extreme events and other economic, social and environmental shocks and disasters; significant mobilization of resources from a variety of sources; and the development of policy frameworks at national, regional, and international levels to support the eradication of poverty. ${ }^{718}$

The provisions of Goal 1 and its targets encompass legally cognizable human rights stated, as follows, in Article 11(1) of the International Convention on Economic, Social, and Cultural Rights (ICESCR): ${ }^{.19}$

1. The States Parties to the present Covenant recognize the right of everyone to an adequate standard of living for himself and his family, including adequate food, clothing and housing, and to the continuous improvement of living conditions. The States Parties will take appropriate steps to ensure the realization of this right, recognizing to this effect the essential importance of international co-operation based on free consent.

716. U.N. General Assembly Resolution A/RES/70/1, supra note 1, Goal 1.

717. U.N. General Assembly Resolution A/RES/70/1, supra note 1, Goal 1, Targets $1.1-1.3$.

718. See Id. Targets $1.4-1 . \mathrm{b}$ 
719. International Covenant on Economic, Social, and Cultural Rights (ICESCR),

supra note 9 , art. 11(1).

The provisions of Goal 1 and its targets are in accord with provisions of the International Convention on the Elimination of All Forms of Racial Discrimination (CERD), Article 2(1) of which states: "States Parties condemn racial discrimination and undertake to pursue by all appropriate means and without delay a policy of eliminating racial discrimination in all its forms and promoting understanding among all races, . . . .,720

The mandate in Target 1.5 to, “. . . build the resilience of . . . those in vulnerable situations and reduce their exposure and vulnerability to climate-related extreme events . . ." indicates that the provisions of Goal 1 and its targets are in accord with provisions of the Convention concerning Indigenous and Tribal Peoples in Independent Countries (ILO No. 169), Article 2 of which states the following: $:^{721}$

1. Governments shall have the responsibility for developing, with the participation of [indigenous and tribal peoples], coordinated and systematic action to protect the rights of these peoples and to guarantee respect for their integrity.

The terms of Target 1.5, indicate also that provisions of Goal 1 and its targets are in accord with provisions of the United Nations Declaration on the Rights of Indigenous Peoples (UNDRIP), Article 21(2) of which states the following: ${ }^{722}$

21(2). States shall take effective measures and, where appropriate, special measures to ensure continuing improvement of [indigenous people's] economic and social conditions.

720.. International Convention on the Elimination of All Forms of Racial Discrimination CERD), supra note 27, art 2(1).

721. Convention concerning Indigenous and Tribal Peoples in Independent Countries 
(ILO No. 169), (1989), supra note 32, art. 2(2)(b).

722. U.N. Declaration on the Rights of Indigenous Peoples (UNDRIP), A/RES/61/295, (2007), supra note 33, art. 21(2).

\section{Analysis of Content of Goal 2}

Goal 2 of U.N. General Assembly Resolution A/RES/70/1 states the following: "End hunger, achieve food security and improved nutrition and

promote sustainable agriculture., ${ }^{, 723}$ The targets of Goal 2 include the ensuring, by 2030, of universal access by all people, in particular the poor and those in vulnerable situations, to safe, nutritious, and sufficient food all the year round; the ending of all forms of malnutrition including the achievement, by 2025, of internationally agreed targets on stunting in children under 5 years of age. ${ }^{\mathbf{7 2 4}}$

Further, the tasks include doubling of agricultural productivity levels of small-scale food producers, in particular women, indigenous peoples, family farmers, pastoralists and fishers; the development of agricultural practices that will strengthen capacity for adaptation to adverse environmental events; and maintenance of genetic diversity of plants, and animals. ${ }^{725}$ These targets seek also increased investment, including through enhanced international cooperation, in rural infrastructure, agricultural research, and technology, prevention of trade restrictions and distortions in world agricultural markets, and adoption of measures to ensure proper functioning of food commodity markets. ${ }^{\mathbf{7 2 6}}$

The provisions of Goal 2 and its targets encompass legally cognizable

723. U.N. General Assembly Resolution A/RES/70/1, supra note 1, Goal 2.

724. U.N. General Assembly Resolution A/RES/70/1, supra note 1, Goal 2, Targets $2.1-2.2$.

725. U.N. General Assembly Resolution A/RES/70/1, supra note 1, Goal 2, 
Targets $2.3-2.5$.

726. U.N. General Assembly Resolution A/RES/70/1, supra note 1, Goal 2,

Targets 2.a-2.c.

human rights stated, as follows, in ICESCR Article 11(2): ${ }^{727}$

2. The States Parties to the present Covenant, recognizing the fundamental right of everyone to be free from hunger, shall take, individually and through international co-operation, the measures, including specific programmes, which are needed:

(a) To improve methods of production, conservation and distribut ion of food by making full use of technical and scientific knowledge, by disseminating knowledge of the principles of nutrition and by developing or reforming agrarian systems in such a way as to achieve the most efficient development and utilization of natural resources;

(b) Taking into account the problems of both food-importing and food-exporting countries, to ensure an equitable distribution of world food supplies in relation to need.

The provisions of Goal 2 and its targets are in accord with provisions

of the International Convention on the Elimination of All Forms of Racial

Discrimination (CERD), Article 2(1) of which states: "States Parties condemn racial discrimination and undertake to pursue by all appropriate means and without delay a policy of eliminating racial discrimination in all its forms and promoting understanding among all races, . . . .,728

The provisions of Goal 2 and its targets are informed by provisions of the Convention for the Elimination of All Forms of Discrimination Against

727. International Covenant on Economic, Social, and Cultural Rights (ICESCR), supra note 9 , art. 11(2).

728.. International Convention on the Elimination of All Forms of Racial Discrimination CERD), supra note 27, art 2(1). 
Women (CEDAW), Article 2 of which states: ${ }^{729}$

States Parties condemn discrimination against women in all its forms, agree to pursue by all appropriate means and without delay a policy of eliminating discrimination against women . . .

Further, the provisions of Goal 2 and its targets are informed by provisions

of the Convention concerning Indigenous and Tribal Peoples in Independent

Countries (ILO No. 169), Article 2 of which states the following: ${ }^{730}$

1. Governments shall have the responsibility for developing, with the participation of [indigenous and tribal peoples], coordinated and systematic action to protect the rights of these peoples and to guarantee respect for their integrity.

2. Such action shall include measures for:

(b) promoting the full reali[s]ation of the social, economic and cultural rights of these peoples with respect for their social and cultural identity, their customs and traditions and their institutions; . . . .

The provisions of Goal 2 and its targets are also informed by provisions of the

United Nations Declaration on the Rights of Indigenous Peoples (UNDRIP),

Article 21 of which states the following: ${ }^{731}$

States shall take effective measures and, where appropriate, special measures to ensure continuing improvement of [indigenous people's] economic and social conditions.

729. Convention on the Elimination of All Forms of Discrimination against Women (CEDAW), supra note 30, art 2.

730. Convention concerning Indigenous and Tribal Peoples in Independent Countries (ILO No. 169), (1989), supra note 32, art. 2(2)(b).

731. U.N. Declaration on the Rights of Indigenous Peoples (UNDRIP), A/RES/61/295, (2007), supra note 33, art. 21(2). 


\section{Analysis of Content of Goal 3}

Goal 3 of U.N. General Assembly Resolution A/RES/70/1 states the following: "Ensure healthy lives and promote well-being for all at all ages.",732 The targets of Goal 3 include the reduction, by 2030, of the global maternal mortality ratio to less than 70 per 100,000 live births, and the ending, by 2030 , of preventable deaths of newborns and children under 5 years of age; the ending, (by 2030), of the epidemics of AIDS, tuberculosis, malaria and neglected tropical diseases, and the combating of hepatitis, water-borne diseases and other communicable diseases; the reduction, by 2030 , by one third, of premature mortality from non-communicable diseases through prevention and treatment, and promotion of mental health and well-being ${ }^{733}$

Further, these targets include the halving, by 2020 of the number of global deaths and injuries from road traffic accidents; the ensuring, by 2030, of universal access to sexual and reproductive health-care services, and the setting up of universal health coverage; substantial reduction, by 2030, of the number of deaths and illnesses from hazardous chemicals and air, water and soil pollution and contamination. ${ }^{\mathbf{7 3 4}}$

Finally, the targets include strengthening of the implementation of the World Health Organization Framework Convention on Tobacco Control in all countries, as appropriate; support for the research and development of vaccines

732. U.N. General Assembly Resolution A/RES/70/1, supra note 1, Goal 3.

733. U.N. General Assembly Res. A/RES/70/1, supra note 1, Goal 3, Targets 3.1 - 3.4.

734. U.N. General Assembly Res. A/RES/70/1, supra note 1, Goal 3, Targets 3.5 - 3.9. 
and medicines, substantial increase of health financing and the recruitment, development, training and retention of health workforces in developing countries; and the strengthening of the capacities of all countries for early warning, risk reduction and management of health risks. ${ }^{\mathbf{7 3 5}}$

The provisions of Goal 3 and its targets encompass legally cognizable human rights stated, as follows, in ICESCR Article $12:^{736}$

1. The States Parties to the present Covenant recognize the right of everyone to the enjoyment of the highest attainable standard of physical and mental health.

2. The steps to be taken by the States Parties to the present Covenant to achieve the full realization of this right shall include those necessary for:

(a) The provision for the reduction of the stillbirth-rate and of infant mortality and for the healthy development of the child;

(b) The improvement of all aspects of environmental and industrial hygiene;

(c) The prevention, treatment and control of epidemic, endemic, occupational and other diseases;

(d) The creation of conditions which would assure to all medical service and medical attention in the event of sickness.

The provisions of Goal 3 and its targets are in accord with provisions of the International Convention on the Elimination of All Forms of Racial Discrimination (CERD), Article 2(1) of which states: "States Parties condemn racial discrimination and undertake to pursue by all appropriate means and without delay a policy of eliminating racial discrimination in all its forms and promoting understanding among all races, . . . .,737

735. U.N. General Assembly Res. A/RES/70/1, supra note 1, Goal 3, Targets 3.a - 3.d.

736. International Covenant on Economic, Social, and Cultural Rights (ICESCR), ॥ supra note 9, art. 12.

737. International Convention on the Elimination of All Forms of Racial Discrimination CERD), supra note 27, art 2(1). 


\section{Analysis of Content of Goal 4}

Goal 4 of U.N. General Assembly Resolution A/RES/70/1 states the following: "Ensure inclusive and equitable quality education and promote lifelong learning opportunities for all." ${ }^{\mathbf{7 3 8}}$ The targets of Goal 4 include provisions to ensure that, by 2030, all girls and boys will have access to free, equitable, and quality primary and secondary education; to quality early childhood development, care and pre-primary education; that all women and men will have equal access to affordable and quality technical, vocational and tertiary education, including university education. ${ }^{739}$

Further, the targets call for the elimination, by 2030, of gender disparities in education; the ensuring, by 2030, of equal access to all levels of educational and vocational training for the vulnerable, including persons with disabilities, indigenous peoples and children in vulnerable situations; that, by 2030, all youth and a substantial proportion of adults, achieve literacy and numeracy; and that, by 2030, all learners acquire the knowledge and skills needed to promote sustainable development. ${ }^{\mathbf{7 0}}$

Finally, the targets call for the building and upgrading of educational facilities that are child, disability and gender sensitive and provide safe, nonviolent, inclusive and effective learning environments for all; the substantial expansion, by 2020, of the number of scholarships available to developing countries; and a substantial increase, through programs of international

738. U.N. General Assembly Resolution A/RES/70/1, supra note 1, Goal 4.

739. U.N. General Assembly Res. A/RES/70/1, supra note 1, Goal 4, Targets 4.1 - 4.3.

740.. $\quad$ U.N. General Assembly Res. A/RES/70/1, supra note 1, Goal 4, Targets 4.4 - 4.7. 
cooperation, of the supply of qualified teachers. ${ }^{\mathbf{7 4 1}}$

The provisions of Goal 4 and its targets encompass legally cognizable

human rights stated, as follows, in ICESCR Article $13:^{742}$

1. The States Parties to the present Covenant recognize the right of everyone to education. They agree that education shall be directed to the full development of the human personality and the sense of its dignity, and shall strengthen the respect for human rights and fundamental freedoms. They further agree that education shall enable all persons to participate effectively in a free society, promote understanding, tolerance and friendship among all nations and all racial, ethnic or religious groups, and further the activities of the United Nations for the maintenance of peace. . . . .

2. The States Parties to the present Covenant recognize that, with a view to achieving the full realization of this right:

(a) Primary education shall be compulsory and available free to all;

(b) Secondary education in its different forms, including technical and vocational secondary education, shall be made generally available and accessible to all by every appropriate means, and in particular by the progressive introduction of free education;

(c) Higher education shall be made equally accessible to all, on the basis of capacity, by every appropriate means, and in particular by the progressive introduction of free education;

(d) Fundamental education shall be encouraged or intensified as far as possible for those persons who have not received or completed the whole period of their primary education;

(e) The development of a system of schools at all levels shall be actively pursued, an adequate fellowship system shall be established, and the material conditions of teaching staff shall be continuously improved.

3. The States Parties to the present Covenant undertake to have respect for the liberty of parents and, when applicable, legal guardians to choose for their children schools, other than those established by the public authorities, which conform to such minimum educational standards as may be laid down or approved by the State and to ensure the religious and moral education of their children in conformity with their own convictions.

741. U.N. General Assembly Res. A/RES/70/1, supra note 1, Goal 4, Targets 4.8 - 4.c.

742. International Covenant on Economic, Social, and Cultural Rights (ICESCR), supra note 9 , art. 13. 
4. No part of this article shall be construed so as to interfere with the liberty of individuals and bodies to establish and direct educational institutions, subject always to the observance of the principles set forth in paragraph I of this article and to the requirement that the education given in such institutions shall conform to such minimum standards as may be laid down by the State.

The provisions of Goal 4 and its targets are in accord with provisions of the International Convention on the Elimination of All Forms of Racial Discrimination (CERD), Article 2(1) of which states: "States Parties condemn racial discrimination and undertake to pursue by all appropriate means and without delay a policy of eliminating racial discrimination in all its forms and promoting understanding among all races, . . . .,743

The provisions of Goal 4 and its targets are informed by provisions of the Convention concerning Indigenous and Tribal Peoples in Independent Countries (ILO No. 169), Article 2 of which states the following: ${ }^{744}$

1. Governments shall have the responsibility for developing, with the participation of [indigenous and tribal peoples], coordinated and systematic action to protect the rights of these peoples and to guarantee respect for their integrity.

2. Such action shall include measures for:

(b) promoting the full realisation of the social, economic and cultural rights of these peoples with respect for their social and cultural identity, their customs and traditions and their institutions; . . . .

743. International Convention on the Elimination of All Forms of Racial Discrimination CERD), supra note 27, art 2(1).

744. Convention concerning Indigenous and Tribal Peoples in Independent Countries (ILO No. 169), (1989), supra note 32, art. 2(2)(b). 


\section{Analysis of Content of Goal 5}

Goal 5 of U.N. General Assembly Resolution A/RES/70/1 states the following: "Achieve gender equality and empower all women and girls."745 The targets of Goal 5 include the ending of all forms of discrimination against all women and girls everywhere. ${ }^{\mathbf{7 4 6}}$ Further, these targets state a commitment to the elimination of all forms of violence against all women and girls, and all harmful practices, such as child, early and forced marriage and female genital mutila tion. ${ }^{747}$ The targets include also the recognition and valuation of unpaid care and domestic work through the provisioning of public services, infrastructure and social protection policies. ${ }^{\mathbf{7 4 8}}$

Additional targets of Goal 5 include the ensuring of women's full and effective participation and equal opportunities for leadership at all levels of decision-making in political, economic, and public life. ${ }^{\mathbf{7 4 9}}$ Further, these targets include universal access to sexual and reproduce tive health and reproductive rights; and reforms to give women equal rights to economic resources. ${ }^{\mathbf{7 4 0}}$ The targets include also enhancement of the use of enabling technology (in particular information and communications technology) to promote the empowerment of women. ${ }^{751}$ Finally, the targets state a commitment

745. U.N. General Assembly Res. A/RES/70/1, supra note 1, Goal 5.

746. U.N. General Assembly Res. A/RES/70/1, supra note 1, Goal 5, Target 5.1.

747. U.N. General Assembly Res. A/RES/70/1, supra note 1, Goal 5, Targets 5.2 - 5.3.

748. U.N. General Assembly Res. A/RES/70/1, supra note 1, Goal 5, Target 5.4.

749. U.N. General Assembly Res. A/RES/70/1, supra note 1, Goal 5, Target 5.5.

750. U.N. General Assembly Res. A/RES/70/1, supra note 1, Goal 5, Target 5.a.

751. U.N. General Assembly Res. A/RES/70/1, supra note 1, Goal 5, Target 5.b. 
to the promotion of gender equality and the empowerment of women and girls at all levels. ${ }^{752}$

The provisions of Goal 5 and its targets encompass legally cognizable human rights stated, as follows, in Article 3 of the International Covenant on Economic, Social, and Cultural Rights (ICESCR), and Article 3 of the International Covenant on Civil and Political Rights (ICCPR):

ICESCR Article 3:

The States Parties to the present Covenant undertake to ensure the equal right of men and women to the enjoyment of all economic, social and cultural rights set forth in the present Covenant. ${ }^{753}$

ICCPR Article 3:

The States Parties to the present Covenant undertake to ensure the equal right of men and women to the enjoyment of all civil and political rights set forth in the present Covenant. ${ }^{754}$

The provisions of Goal 5 and its targets are informed by provisions of

of the Convention for the Elimination of All Forms of Discrimination Against

Women (CEDAW), Article 2 of which states: ${ }^{.75}$

CEDAW Article 2:

States Parties condemn discrimination against women in all its forms, agree to pursue by all appropriate means and without delay a policy of eliminating discrimination against women and, to this end, undertake:

(a) To embody the principle of the equality of men and women in their national constitutions or other appropriate legislation if not yet incorporated therein and to ensure,

752. U.N. General Assembly Res. A/RES/70/1, supra note 1, Goal 5, Target 5.c.

753. International Covenant on Economic, Social, and Cultural Rights (ICESCR), supra note 9 , art. 3.

754. International Covenant on Civil and Political Rights (ICCPR), supra note 9, art. 3.

755. Convention on the Elimination of All Forms of Discrimination against Women (CEDAW), supra note 30, art 2. 
through law and other appropriate means, the practical realization of this principle;

(b) To adopt appropriate legislative and other measures, including sanctions where appropriate, prohibiting all discrimination against women;

(c) To establish legal protection of the rights of women on an equal basis with men and to ensure through competent national tribunals and other public institutions the effective protection of women against any act of discrimination;

(d) To refrain from engaging in any act or practice of discrimination against women and to ensure that public authorities and institutions shall act in conformity with this obligation;

(e) To take all appropriate measures to eliminate discrimination against women by any person, organization or enterprise;

(f) To take all appropriate measures, including legislation, to modify or abolish existing laws, regulations, customs and practices which constitute discrimination against women;

(g) To repeal all national penal provisions which constitute discrimination against women.

\section{Analysis of Content of Goal 6}

Goal 6 of U.N. General Assembly Resolution A/RES/70/1 states the following: "Ensure availability and sustainable management of water and sanitation for all."756 The targets of Goal 6 include, the achievement, by 2030, of universal and equitable access to safe and affordable drinking water, and access to adequate and equitable sanitation and hygiene for all, with special

756. U.N. General Assembly Res. A/RES/70/1, supra note 1, Goal 6. 
attention to the needs of women and girls, and those in vulnerable situations. ${ }^{\mathbf{7 5 7}}$

The targets include also the improvement of water quality and water-use efficiency, and the implementation of integrated water resource management at all levels. ${ }^{\mathbf{7 5 8}}$ Further, the targets of Goal 6 include, the protection and restoration, (by 2030), of water-related ecosystems, including mountains, forests, wetlands, rivers, aquifers and lakes. ${ }^{759}$ The targets include, also, by 2030, the expansion of international cooperation and capacity-building support to developing countries in water- and sanitation-related activities. ${ }^{\mathbf{7 6 0}}$ Finally, the targets of Goal 6 call for the supporting and strengthening of the participation of local communities in improving water and sanitation management. ${ }^{761}$

The provisions of Goal 6 and its targets, implicate legally cognizable human rights stated, as follows, in ICESCR Articles 11(1), 12(1) and 12(2):

ICESCR Article $11:^{\mathbf{7 6 2}}$

1. The States Parties to the present Covenant recognize the right of of everyone to an adequate standard of living for himself and his family, including adequate food, clothing and housing, and to the continuous improvement of living conditions. The States Parties will take appropriate steps to ensure the realization of this right, recognizing to this effect the essential importance of international co-operation based on free consent.

757. U.N. General Assembly Res. A/RES/70/1, supra note 1. Goal 6, Targets 6.1 - 6.2.

758. U.N. General Assembly Res. A/RES/70/1, supra note 1. Goal 6, Targets 6.3 - 6.5.

759. U.N. General Assembly Res. A/RES/70/1, supra note 1. Goal 6, Target 6.6.

760. U.N. General Assembly Res. A/RES/70/1, supra note 1. Goal 6, Target 6.a.

761. U.N. General Assembly Res. A/RES/70/1, supra note 1. Goal 6, Target 6.b.

762. International Covenant on Economic, Social, and Cultural Rights (ICESCR), supra note 9, art. 11(1). 
ICESCR Article $12:^{763}$

1. The States Parties to the present Covenant recognize the right of everyone to the enjoyment of the highest attainable standard of physical and mental health.

2. The steps to be taken by the States Parties to the present Covenant to achieve the full realization of this right shall include those necessary for:

(a) The provision for the reduction of the stillbirth-rate and of infant mortality and for the healthy development of the child;

(b) The improvement of all aspects of environmental and industrial hygiene;

(c) The prevention, treatment and control of epidemic, endemic, occupational and other diseases;

(d) The creation of conditions which would assure to all medical service and medical attention in the event of sickness.

The Committee on Economic, Social, and Cultural Rights, has clarified the meaning of the right to an adequate standard of living stated in the ICESCR, Articles 11 and 12, as encompassing "a number of rights emanating from, and indispensable for, the realization of the right," including the rights to adequate housing, adequate food, and safe and clean drinking water and sanitation. ${ }^{\mathbf{7 6 4}}$

Further, the provisions of Goal 6 and its targets encompass legally cognizable human rights stated, as follows, in Article 3 of the International Covenant on Economic, Social, and Cultural Rights (ICESCR), and Article 3 of the International Covenant on Civil and Political Rights (ICCPR):

ICESCR Article 3:

The States Parties to the present Covenant undertake to ensure the equal right of men and women to the enjoyment of all economic, social and cultural rights set forth in the present Covenant. ${ }^{\mathbf{7 6 5}}$

763. International Covenant on Economic, Social, and Cultural Rights (ICESCR), supra note 9, art. 12(1), (2).

764. See The Committee on Economic, Social, and Cultural Rights, General Comment No. 15:

765. International Covenant on Economic, Social, and Cultural Rights (ICESCR), supra note 9, art. 3. 
ICCPR Article 3:

The States Parties to the present Covenant undertake to ensure the equal right of men and women to the enjoyment of all civil and political rights set forth in the present Covenant. ${ }^{766}$

The provisions of Goal 6 and its targets are in accord with provisions

of the International Convention on the Elimination of All Forms of Racial Discrimination (CERD), Article 2(1) of which states: "States Parties condemn racial discrimination and undertake to pursue by all appropriate means and without delay a policy of eliminating racial discrimination in all its forms and promoting understanding among all races, . . . .,767

The provisions of Goal 6 and its targets are also informed by provisions of the Convention for the Elimination of All Forms of Discrimination Against Women (CEDAW), Article 2 of which states: ${ }^{768}$

CEDAW Article 2:

States Parties condemn discrimination against women in all its forms, agree to pursue by all appropriate means and without delay a policy of eliminating discrimination against women and, to this end, undertake:

(a) To embody the principle of the equality of men and women in their national constitutions or other appropriate legislation if not yet incorporated therein and to ensure, through law and other appropriate means, the practical realization of this principle;

(b) To adopt appropriate legislative and other measures, including sanctions where appropriate, prohibiting all discrimination against women;

766. International Covenant on Civil and Political Rights (ICCPR), supra note 9, art. 3.

767.. International Convention on the Elimination of All Forms of Racial Discrimination CERD), supra note 27, art 2(1).

768. Convention on the Elimination of All Forms of Discrimination against Women (CEDAW), supra note 30, art 2. 
(c) To establish legal protection of the rights of women on an equal basis with men and to ensure through competent national tribunals and other public institutions the effective protection of women against any act of discrimination;

(d) To refrain from engaging in any act or practice of discrimination against women and to ensure that public authorities and institutions shall act in conformity with this obligation;

In addition to the foregoing, Target 6.2's particular language, “. . . with special attention to the needs of . . . those in vulnerable situations . . . “ indicates that the provisions of Goal 6 and its targets are in accord with provisions of the Convention concerning Indigenous and Tribal Peoples in Independent Countries (ILO No. 169), Article 2 of which states: ${ }^{769}$

1. Governments shall have the responsibility for developing, with the participation of [indigenous and tribal peoples], coordinated and systematic action to protect the rights of these peoples and to guarantee respect for their integrity.

2. Such action shall include measures for:

(b) promoting the full realisation of the social, economic and cultural rights of these peoples with respect for their social and cultural identity, their customs and traditions ; . . .

The specific language of Target 6.2, presented in the immediately preceding paragraph of this writing, indicates also that provisions of Goal 6 and its targets are in accord with provisions of the U.N. Declaration on the Rights of Indigenous Peoples. ${ }^{770}$

769. Convention concerning Indigenous and Tribal Peoples in Independent Countries (ILO No. 169), (1989), supra note 32, art. 2(2)(b).

770. U.N. Declaration on the Rights of Indigenous Peoples (UNDRIP), A/RES/61/295, (2007), supra note 33, art. 21(2). 


\section{Analysis of Content of Goal 7}

\section{Goal 7 of U.N. General Assembly Resolution A/RES/70/1 states}

the following: "Ensure access to affordable, reliable, sustainable and modern energy for all., ${ }^{, 768}$ The targets of Goal 7 include universal access, by 2030, to affordable, reliable, and modern energy services, substantial increase in the share of renewable energy in the global energy mix, and a doubling of the global rate of improvement in energy efficiency. ${ }^{769}$ Further, the targets of Goal 7 provide for enhanced international cooperation in research into clean energy, and expanded infrastructure to supply of modern and sustainable energy services to all. ${ }^{\mathbf{7 7 0}}$

The provisions of Goal 7 and its targets, implicate legally cognizable human rights stated, as follows, in ICESCR Articles 11(1), 12(1), and 12(2):

ICESCR Article $11:^{.771}$

1. The States Parties to the present Covenant recognize the right of of everyone to an adequate standard of living for himself and his family, including adequate food, clothing and housing, and to the continuous improvement of living conditions. The States Parties will take appropriate steps to ensure the realization of this right, recognizing to this effect the essential importance of international co-operation based on free consent.

ICESCR Article $12:^{772}$

1. The States Parties to the present Covenant recognize the right of everyone to the enjoyment of the highest attainable standard of physical and mental health.

768. U.N. General Assembly Res. A/RES/70/1, supra note 1, Goal 7.

769. U.N. General Assembly Res. A/RES/70/1, supra note 1, Goal 7, Targets 7.1 - 7.3.

770. U.N. General Assembly Res. A/RES/70/1, supra note 1, Goal 7, Targets 7.4 - 7.b.

771. International Covenant on Economic, Social, and Cultural Rights (ICESCR), supra note 9, art. 11(1).

772. International Covenant on Economic, Social, and Cultural Rights (ICESCR), supra note 9, art. 12(1), (2). 
2. The steps to be taken by the States Parties to the present Covenant to achieve the full realization of this right shall include those necessary for:

(a) The provision for the reduction of the stillbirth-rate and of infant mortality and for the healthy development of the child;

(b) The improvement of all aspects of environmental and industrial hygiene;

(c) The prevention, treatment and control of epidemic, endemic, occupational and other diseases;

(d) The creation of conditions which would assure to all medical service and medical attention in the event of sickness.

The Committee on Economic, Social, and Cultural Rights, has clarified the meaning of the right to an adequate standard of living stated in the ICESCR, Articles 11 and 12, as encompassing "a number of rights emanating from, and indispensable for, the realization of the right," including the rights to adequate housing, adequate food, and safe and clean drinking water and sanitation. ${ }^{773}$

The provisions of Goal 7 and its targets are in accord with provisions of the International Convention on the Elimination of All Forms of Racial Discrimination (CERD), Article 2(1) of which states: "States Parties condemn racial discrimination and undertake to pursue by all appropriate means and without delay a policy of eliminating racial discrimination in all its forms and promoting understanding among all races, . . . .,"774

773. See The Committee on Economic, Social, and Cultural Rights, General Comment No. 15: The right to water (arts. 11 and 12 of the International Covenant on Economic, Social and Cultural Rights), January 20, 2003, U.N. Doc. E/C.12/2002/11, II 3.

774. U.N. General Assembly Res. A/RES/70/1, supra note 1, Goal 8. 


\section{Analysis of Content of Goal 8}

Goal 8 of U.N. General Assembly Resolution A/RES/70/1 states the following: "Promote sustained, inclusive and sustainable economic growth, full and productive employment and decent work for all." ${ }^{, 775}$ The targets of Goal 8 include the sustaining of economic growth, at a level of, at least, 7 per cent of gross domestic product in the least developed countries, and the achievement of higher levels of economic productivity through diversification, upgrading of technology, and innovation. ${ }^{776}$

Further, these targets include the promotion of development-oriented policies that support productive activities, decent job creation, entrepreneurship, creativity and innovation. ${ }^{777}$ The targets include also the progressive improvement, through 2030, of global resource efficiency in consumption and production; and the decoupling of economic growth from environmental degradation, in accordance with the 10-Year Framework of Programmes on Sustainable Consumption and Production, with developed countries taking the lead. ${ }^{778}$

In addition, the targets of Goal 8 include the achievement, by 2030, of full and productive employment and decent work for all women and men, including young people and persons with disabilities, and equal pay for work of

equal value. ${ }^{779}$ Further, these targets include the substantial reduction, by 2020 , of youth not in employment, education or training. The targets include

775. U.N. General Assembly Res. A/RES/70/1, supra note 1, Goal 8, Targets 8.1 - 8.2.

776. U.N. General Assembly Res. A/RES/70/1, supra note 1, Goal 8, Target 8.3.

777. U.N. General Assembly Res. A/RES/70/1, supra note 1, Goal 8, Target 8.4.

778. U.N. General Assembly Res. A/RES/70/1, supra note 1, Goal 8, Target 8.5.

779. U.N. General Assembly Res. A/RES/70/1, supra note 1, Goal 8, Target 8.6. 
immediate and effective measures to eradicate forced labor, end human trafficking, and the ending, by 2025, of child labor in all its forms ${ }^{780}$ Finally, the targets of Goal 8 include the protection of labor rights; the strengthening of the capacities of domestic financial institutions; increased trade support for developing countries, and the formulation, by 2020, of a global strategy for \ the employment of youth. ${ }^{781}$

The provisions of Goal 8 and its targets, encompass legally cognizable human rights stated, as follows, in ICESCR Articles 6 and 11:

ICESCR Article 6: ${ }^{782}$

1. The States Parties to the present Covenant recognize the right to work, which includes the right of everyone to the opportunity to gain his living by work which he freely chooses or accepts, and will take appropriate steps to safeguard this right.

2. The steps to be taken by a State Party to the present Covenant to achieve the full realization of this right shall include technical and vocational guidance and training programmes, policies and techniques to achieve steady economic, social and cultural development and full and productive employment under conditions safeguarding fundamental political and economic freedoms to the individual.

ICESCR Article 11: ${ }^{783}$

1. The States Parties to the present Covenant recognize the right of everyone to an adequate standard of living for himself and his family, including adequate food, clothing and housing, and to the continuous improvement of living conditions. The States Parties will take appropriate steps to ensure the

780. U.N. General Assembly Res. A/RES/70/1, supra note 1, Goal 8, Target 8.7.

781. U.N. General Assembly Res. A/RES/70/1, supra note 1, Goal 8, Targets 8.8 - 8.b.

782. International Covenant on Economic, Social, and Cultural Rights (ICESCR), supra note 9 , art. 6(1), (2).

783. International Covenant on Economic, Social, and Cultural Rights (ICESCR), supra note 9 , art. 11(1). 
realization of this right, recognizing to this effect the essential importance of international co-operation based on free consent.

The provisions of Goal 8 and its targets are in accord with provisions of the International Convention on the Elimination of All Forms of Racial Discrimination (CERD), Article 2(1) of which states: "States Parties condemn racial discrimination and undertake to pursue by all appropriate means and without delay a policy of eliminating racial discrimination in all its forms and promoting understanding among all races, . . ..,784

The provisions of Target 8.7 are in accord with provisions of the Convention on the Rights of the Child (CRC), Article 32 of which states the following:

CRC Article $32:^{785}$

1. States Parties recognize the right of the child to be protected from economic exploitation and from performing any work that is likely to be hazardous or to interfere with the child's education, or to be harmful to the child's health or physical, mental, spiritual, moral or social development.

2. States Parties shall take legislative, administrative, social and educational measures to ensure the implementation of the present article. To this end, and having regard to the relevant provisions of other international instruments, States Parties shall in particular:

(a) Provide for a minimum age or minimum ages for admission to employment;

(b) Provide for appropriate regulation of the hours and conditions of employment;

(c) Provide for appropriate penalties or other sanctions to ensure the effective enforcement of the present article.

784.. International Convention on the Elimination of All Forms of Racial Discrimination CERD), supra note 27, art 2(1).

785. Convention on the Rights of the Child (CRC), supra note 31, art 32(1). 


\section{Analysis of Content of Goal 9}

Goal 9 of U.N. General Assembly Resolution A/RES/70/1 states the following: "Build resilient infrastructure, promote inclusive and sustainable industrialization and foster innovation." ${ }^{\mathbf{7 8 6}}$ The targets of Goal 9 include the development of high-quality, reliable, sustainable and resilient infrastructure, with a focus on affordable and equitable access for all, the promotion of inclusive and sustainable industrialization, and, by 2030, the achieving of a significant raising of industry's share of employment and gross domestic product. ${ }^{\mathbf{7 8 7}}$ Further, these targets include increase of access of small-scale industrial and other enterprises to financial services. ${ }^{\mathbf{7 8 8}}$ The targets include also the upgrading, by 2030, of infrastructure and retrofitting of industries to make them sustainable, and the enhancing of scientific research, and upgrading of the technological capabilities of industrial sectors in all countries, in particular developing countries. ${ }^{\mathbf{7 8 9}}$

In addition, the targets of Goal 9 include the facilitation of sustainable and resilient infrastructure development in developing countries through enhanced financial, technological, and technical support, with particular reference to African countries, least developed countries, landlocked developing countries and small island developing States. ${ }^{\mathbf{7 9 0}}$ Finally, these targets include the supporting of domestic technology development, research and innovation in developing countries; and the significant increasing of access to information and

786. U.N. General Assembly Resolution A/RES/70/1, supra note 1, Goal 9.

787. U.N. General Assembly Res. A/RES/70/1, supra note 1, Goal 9, Targets 9.1 - 9.2.

788. U.N. General Assembly Res. A/RES/70/1, supra note 1, Goal 9, Target 9.3.

789. U.N. General Assembly Res. A/RES/70/1, supra note 1, Goal 9, Targets 9.4 - 9.5.

790. U.N. General Assembly Res. A/RES/70/1, supra note 1, Goal 9, Target 9.a. 
communications technology, with particular reference to the internet. ${ }^{791}$

The provisions of Goal 9, and its targets, encompass legally cognizable

human rights stated, as follows, in ICESCR Articles 6 and 11:

ICESCR Article $6:^{792}$

1. The States Parties to the present Covenant recognize the right to work, which includes the right of everyone to the opportunity to gain his living by work which he freely chooses or accepts, and will take appropriate steps to safeguard this right.

2. The steps to be taken by a State Party to the present Covenant to achieve the full realization of this right shall include technical and vocational guidance and training programmes, policies and techniques to achieve steady economic, social and cultural development and full and productive employment under conditions safeguarding fundamental political and economic freedoms to the individual.

ICESCR Article 117: ${ }^{793}$

1. The States Parties to the present Covenant recognize the right of everyone to an adequate standard of living for himself and his family, including adequate food, clothing and housing, and to the continuous improvement of living conditions. The States Parties will take appropriate steps to ensure the realization of this right, recognizing to this effect the essential importance of international co-operation based on free consent.

The provisions of Goal 9 and its targets are in accord with provisions

of the International Convention on the Elimination of All Forms of Racial

Discrimination (CERD), Article 2(1) of which states: "States Parties condemn

racial discrimination and undertake to pursue by all appropriate means and

791. U.N. General Assembly Res. A/RES/70/1, supra note 1, Goal 9, Targets 9.b - 9.c.

792. International Covenant on Economic, Social, and Cultural Rights (ICESCR), supra note 9 , art. 6(1), (2),

793. International Covenant on Economic, Social, and Cultural Rights (ICESCR), supra note 9 , art. 11(1). 
without delay a policy of eliminating racial discrimination in all its forms and

promoting understanding among all races, . . . .,794

Further, the provisions of Goal 9 and its targets are informed by provisions

of the Convention on the Rights of the Child (CRC), Article 32 of which states

the following:

CRC Article $32:{ }^{795}$

1. States Parties recognize the right of the child to be protected from economic exploitation and from performing any work that is likely to be hazardous or to interfere with the child's education, or to be harmful to the child's health or physical, mental, spiritual, moral or social development.

2. States Parties shall take legislative, administrative, social and educational measures to ensure the implementation of the present article. To this end, and having regard to the relevant provisions of other international instruments, States Parties shall in particular:

(a) Provide for a minimum age or minimum ages for admission to employment;

(b) Provide for appropriate regulation of the hours and conditions of employment;

(c) Provide for appropriate penalties or other sanctions to ensure the effective enforcement of the present article.

\section{Analysis of Content of Goal 10}

Goal 10 of U.N. General Assembly Resolution A/RES/70/1 states

the following: "Reduce inequality within and among countries.",796 The targets of

Goal 10 include the progressive achievement and sustainment, by 2030, of the income growth of the lowest 40 percent of national populations at rates higher

794. International Convention on the Elimination of All Forms of Racial Discrimination (CERD), supra note 27, art 2(1).

795. Convention on the Rights of the Child (CRC), supra note 31, art 32(1).

796. U.N. General Assembly Res. A/RES/70/1, supra note 1, Goal 10. 
than national averages, the empowerment and promotion, by 2030, of the social, economic, and political inclusion of all, irrespective of age, sex, disability, race, ethnicity, origin, religion or economic or other status; and the ensuring of equal opportunity and reduction of inequalities of outcome. ${ }^{797}$ Further, these targets include improvement in the regulation and monitoring of global financial markets and institutions; and ensuring enhanced representation for developing countries in decision-making in international economic and financial institutions. $^{798}$

In addition, the targets of Goal 10 include facilitation of orderly, safe, regular and responsible migration and mobility of people through the implementation of planned and well-managed migration policies. ${ }^{799}$ The targets include also implementation of the principle of special and differential treatment for developing countries, in accordance with World Trade Organization agreement. ${ }^{\mathbf{8 0 0}}$ Further, the targets encompass encouragement of official development assistance and financial flows, including foreign direct investment, to States where the need is greatest; and the reduction, by 2030 , to less than 3 per cent the transaction costs of migrant remittances, and the elimination of remittance corridors with costs higher than 5 per cent. ${ }^{\mathbf{8 0 1}}$

797 U.N. General Assembly Res. A/RES/70/1, supra note 1, Goal 10 Target 10.7.

798. U.N. General Assembly Res. A/RES/70/1, supra note 1, Goal 10, Target 10.a.

799. U.N. General Assembly Res. A/RES/70/1, supra note 1, Goal 10, Targets 10.b.

800. U.N. General Assembly Res. A/RES/70/1, supra note 1, Goal 10, Targets 10.c.

801. International Covenant on Economic, Social, and Cultural Rights (ICESCR), supra note 9 , art. 11(1). 
The provisions of Goal 10 and its targets encompass legally cognizable human rights stated, as follows, in Article 11(1) of the International Convention on Economic, Social, and Cultural Rights (ICESCR): ${ }^{802}$

1. The States Parties to the present Covenant recognize the right of everyone to an adequate standard of living for himself and his family, including adequate food, clothing and housing, and to the continuous improvement of living conditions. The States Parties will take appropriate steps to ensure the realization of this right, recognizing to this effect the essential importance of international co-operation based on free consent.

The provisions of Goal 10 and its targets are informed by provisions of the International Convention on the Elimination of All Forms of Racial Discrimination (CERD), Article 2(1) of which states: "States Parties condemn racial discrimination and undertake to pursue by all appropriate means and without delay a policy of eliminating racial discrimination in all its forms and promoting understanding among all races, . . . ..803

Further, the provisions of Goal 10 and its targets are informed by provisions of the United Nations Convention relating to the Status of Refugees, Article 33(1) of which states: ${ }^{(\mathbf{8 0 4})}$ "No Contracting State shall expel or return ('refouler') a refugee in any manner whatsoever to the frontiers of territories where his life or freedom would be threatened on account of his race, religion, nationality, membership of a particular social group or political opinion. . . ."804

802. International Covenant on Economic, Social, and Cultural Rights (ICESCR), supra note 9 , art. 11(1).

803. International Convention on the Elimination of All Forms of Racial Discrimination CERD), supra note 27, art 2(1).

804. United Nations Convention relating to the Status of Refugees supra note 28, art 33(1). 
The provisions of Goal 10 and its targets are also informed by provisions of International Labour Organization (ILO) Convention No. 111, Article 1, paragraph 1, of which states:

For the purpose of this Convention the term discrimination includes (a) any distinction, exclusion or preference made on the basis of race, colour, sex, religion, political opinion, national extraction or social origin, which has the effect of nullifying or impairing equality of opportunity or treatment in employment or occupation; . . .'

(b) such other distinction, exclusion or preference which has the effect of nullifying or impairing equality of opportunity or treatment in employment or occupation as may be determined by the Member concerned after consultation with representative employers' and workers' organisations, where such exist, and with other appropriate bodies. ${ }^{(806)}$

Article 1, paragraph 3, of ILO Convention No. 111 states: "For the purpose of this Convention the terms employment and occupation include access to vocational training, access to employment and to particular occupations, and terms and conditions of employment.",805

Article 2 of ILO Convention No. 111 states: "Each Member for which this Convention is in force undertakes to declare and pursue a national policy designed to promote, by methods appropriate to national conditions and practice, equality of opportunity and treatment in respect of employment and occupation, with a view to eliminating any discrimination in respect thereof."

804. United Nations Convention relating to the Status of Refugees supra note 28, art 33(1).

805. Discrimination (Employment and Occupation) Convention, ILO Convention No. 111 (Jun. 25, 1958, Jun. 15, 1960), supra note 26, art. 1(1)(a).

806. Discrimination (Employment and Occupation) Convention, ILO Convention No. 111 (Jun. 25, 1958, Jun. 15, 1960), supra note 26, art. 1(1)(b). 
Although the scope of Goal 10 of the 17 Sustainable Development Goals stated in U.N. General Assembly Resolution A/RES/70/1 is broader than that of ILO Convention No. 111, the central principle of both is the elimination of inequalities of opportunity. It appears, therefore, reasonable to maintain that Goal 10 of the 17 Sustainable Development Goals of U.N. General Assembly Resolution A/RES/70/1 is informed by the principles and purposes of ILO Convention No. 111 which addresses issues of discrimination in matters of employment and occupation.

\section{$\underline{\text { Analysis of Content of Goal } 11}$}

Goal 11 of U.N. General Assembly Resolution A/RES/70/1 states the following: "Make cities and human settlements inclusive, safe, resilient and sustainable.”, ${ }^{\mathbf{8 0 8}}$ The targets of Goal 11 include the ensuring, by 2030, of access for all to adequate, safe and affordable housing and basic services, and the upgrading of slums. ${ }^{\mathbf{8 0 9}}$ The targets include also the providing, by 2030, of access to safe, affordable, accessible and sustainable transport systems, with special attention to the needs of those in vulnerable situations, such as women, children, persons with disabilities and older persons. ${ }^{\mathbf{8 1 0}}$ Further, these targets include the enhancement of inclusive and sustainable urbanization and capacity for participatory, integrated and sustainable human settlement planning and management in all countries. ${ }^{\mathbf{8 1 1}}$ The targets include also the strengthening of

808. U.N. General Assembly Res. A/RES/70/1, supra note 1, Goal 11.

809. U.N. General Assembly Res. A/RES/70/1, supra note 1, Goal 11, Target 11.1.

810. U.N. General Assembly Res. A/RES/70/1, supra note 1, Goal 11, Target 11.2.

811. U.N. General Assembly Res A/RES/70/1, supra note 1, Goal 11, Target 11.3. 
efforts to protect and safeguard the world's cultural and natural heritage, and the significant reduction, by 2030 , of the number of deaths, the number of people affected and the direct economic losses caused by disasters. ${ }^{\mathbf{8 1 2}}$

In addition, the targets of Goal 11 include the reduction, by 2030, of the adverse per capita environmental impact on cities, such action to include special attention to air quality and municipal and other waste management, and the public spaces (in particular for women and children, older persons and persons with disabilities). ${ }^{\mathbf{8 1 3}}$ The targets of Goal 11 include also the support of positive economic, social and environmental links between urban, peri-urban, and rural areas. $^{\mathbf{8 1 4}}$ The targets also include the substantial increase, by 2020, of the number of cities and human settlements adopting integrated policies and plans towards inclusion, resource efficiency, mitigation adaptation to climate change, least developed countries through financial and technical assistance in building sustainable and resilient buildings utilizing local materials. ${ }^{\mathbf{8 1 5}}$

The provisions of Goal 11 and its targets encompass legally cognizable human rights stated, as follows, in Article 11(1) of the International Convention on Economic, Social, and Cultural Rights (ICESCR): ${ }^{\mathbf{8 1 6}}$

1. The States Parties to the present Covenant recognize the right of everyone to an adequate standard of living for himself and his family, including adequate food, clothing and housing,

812. U.N. General Assembly Res. A/RES/70/1, supra note 1, Goal 11, Targets 11.4 - 11.5.

813. U.N. General Assembly Res. A/RES/70/1, supra note 1, Goal 11, Targets 11.6 - 11.7.

814. U.N. General Assembly Res. A/RES/70/1, supra note 1, Goal 11, Target 11.a.

815. U.N. General Assembly Res. A/RES/70/1, supra note 1, Goal 11, Targets 11.b - 11.c.

816. International Covenant on Economic, Social, and Cultural Rights (ICESCR), supra note 9 , art. 11(1). 
and to the continuous improvement of living conditions. The States Parties will take appropriate steps to ensure the realization of this right, recognizing to this effect the essential importance of international co-operation based on free consent.

The provisions of Goal 11 and its targets are in accord with provisions of the International Convention on the Elimination of All Forms of Racial Discrimination (CERD), Article 2(1) of which states: "States Parties condemn racial discrimination and undertake to pursue by all appropriate means and without delay a policy of eliminating racial discrimination in all its forms and promoting understanding among all races, . . . .,\$17

\section{$\underline{\text { Analysis of Content of Goal } 12}$}

Goal 12 of U.N. General Assembly Resolution A/RES/70/1 states the following: "Ensure sustainable consumption and production patterns." The targets of Goal 12 include implementation of the 10-Year Framework of [Programs] on Sustainable Consumption and Production Patterns, with the participation of all countries; the achievement, by 2030, of sustainable management and efficient use of natural resources; the halving per capita, by 2030, of global food waste at the retail and consumer levels; and the reduction of food losses along production and supply chains. ${ }^{\mathbf{8 1 9}}$

817. International Convention on the Elimination of All Forms of Racial Discrimination (CERD), supra note 27, art 2(1).

818. U.N. General Assembly Res. A/RES/70/1, supra note 1, Goal 12.

819 U.N. General Assembly Res. A/RES/70/1, supra note 1, Goal 12, Targets $12.1-12.8$. 
Additional targets of Goal 12 include the achievement, by 2020, of environmentally sound management of chemicals and all wastes throughout their life cycles, in accordance with agreed international frameworks; the substantial reduction of waste generation, by 2030, through prevention, reduction, recycling and reuse; and the encouragement of companies, especially large and transnational companies, to adopt sustainable practices and to integrate sustainability information into their reporting cycles. $^{\mathbf{8 2 0}}$ The targets of Goal 12 include also the promotion of public procurement practices that are sustainable, in accordance with national policies and priorities; and the ensuring, by 2030, that people everywhere have the relevant information and awareness for sustainable development and lifestyles in harmony with nature.

The provisions of Goal 12 and its targets are in accord with provisions of the International Convention on the Elimination of All Forms of Racial Discrimination (CERD), Article 2(1) of which states: "States Parties condemn racial discrimination and undertake to pursue by all appropriate means and without delay a policy of eliminating racial discrimination in all its forms and promoting understanding among all races, . . . ..\$21

Finally, the targets of Goal 12 include the providing of support to developing countries to strengthen their scientific and technological capacities to move towards more sustainable patterns of consumption and production; the development and implementation of tools to monitor sustainable development

820 U.N. General Assembly Res. A/RES/70/1, supra note 1, Goal 12, Targets $12.1-12.8$.

821. International Convention on the Elimination of All Forms of Racial Discrimination CERD), supra note 27 , art 2(1). 
development and implementation of tools to monitor sustainable development impacts; and the rationalization of inefficient fossil-fuel subsidies; the restructuring of systems of taxation and the phasing out of harmful subsidies, taking fully into account the specific needs of developing countries and minimizing adverse impacts on their development in a manner that protects the poor and affected communities.

The provisions of Goal 12 and its targets encompass legally cognizable human rights stated, as follows, in Article 11 of the International Convention on Economic, Social, and Cultural Rights (ICESCR): ${ }^{\mathbf{8 2 2}}$

1. The States Parties to the present Covenant recognize the right of of everyone to an adequate standard of living for himself and his family, including adequate food, clothing and housing, and to the continuous improvement of living conditions. The States Parties will take appropriate steps to ensure the realization of this right, recognizing to this effect the essential importance of international cooperation based on free consent.

2. The States Parties to the present Covenant, recognizing the fundamental right of everyone to be free from hunger, shall take, individually and through international co-operation, the measures, including specific programmes, which are needed

(a) To improve methods of production, conservation and distribut ion of food by making full use of technical and scientific knowledge, by disseminating knowledge of the principles of nutrition and by developing or reforming agrarian systems in such a way as to achieve the most efficient development and utilization of natural resources;

(b) Taking into account the problems of both food-importing and food-exporting countries, to ensure an equitable distribution of world food supplies in relation to need.

822. International Covenant on Economic, Social, and Cultural Rights (ICESCR), supra note 9, art. 11. 


\section{Goal 13}

Goal 13 of U.N. General Assembly Resolution A/RES/70/1 states the following: "Take urgent action to combat climate change and its impacts." The targets of Goal 13 include the strengthening, in all countries, of resilience and adaptive capacity to climate-related hazards and natural disasters, the integration of climate-change-management measures into national policies, strategies and planning, and the improvement of education, awareness-raising and human and institutional capacity on climate change mitigation, adaptation, impact reduction and early warning. ${ }^{\mathbf{8 2 4}}$

Additional targets of Goal 13 include implementation of the commitment undertaken by developed-country parties to the United Nations Framework Convention on Climate Change (UNFCCC) to a goal of mobilizing jointly $\$ 100$ billion annually, by 2020, from all sources, to address the needs of developing countries, and the full operationalization of the Green Climate Fund through its capitalization as soon as possible. ${ }^{\mathbf{8 2 5}}$ Finally, these targets include the promotion of mechanisms for raising the capacity for effective climate-change-related planning and management in least developed countries and small island developing States, such measures to include appropriate focus on women, youth and local and marginalized communities. ${ }^{\mathbf{2 2 6}}$

823. U.N. General Assembly Res. A/RES/70/1, supra note 1, Goal13.

824. U.N. General Assembly Res. A/RES/70/1, supra note 1, Goal 13, Targets 13.1 - 13.3.

825. U.N. General Assembly Res. A/RES/70/1, supra note 1, Goal 13, Target 13.a.

826. U.N. General Assembly Res. A/RES/70/1, supra note 1, Goal 13, Target 13.b. 
The provisions of Goal 13 encompass legally cognizable human rights stated in Article 11(1) of the International Convention on Economic, Social, and Cultural Rights (ICESCR): ${ }^{\mathbf{2 7}}$

1. The States Parties to the present Covenant recognize the right of of everyone to an adequate standard of living for himself and his family, including adequate food, clothing and housing, and to the continuous improvement of living conditions. The States Parties will take appropriate steps to ensure the realization of this right, recognizing to this effect the essential importance of international co-operation based on free consent.

Further, the provisions of Goal 13 are informed by principles and terms of the United Nations Framework Convention on Climate Change (UNFCC) ${ }^{\mathbf{8 2 8}}$ and its lineal successor, the Kyoto Protocol to the United Nations Framework Convention on Climate Change. ${ }^{\mathbf{8 2 9}}$

The provisions of Goal 13 and its targets are in accord with provisions of the International Convention on the Elimination of All Forms of Racial Discrimination (CERD), Article 2(1) of which states: "States Parties condemn racial discrimination and undertake to pursue by all appropriate means and without delay a policy of eliminating racial discrimination in all its forms and promoting understanding among all races, . . . .,830

827. International Covenant on Economic, Social, and Cultural Rights (ICESCR), supra note 9 , art. 11(1).

828. United Nations Framework Convention on Climate Change (UNFCCC) (1992), supra note 38.

829. Kyoto Protocol to the United Nations Framework Convention on Climate Change, (1998), supra note 39.

830. International Convention on the Elimination of All Forms of Racial Discrimination CERD), supra note 27, art 2(1). 


\section{Analysis of Content of Goal 14}

Goal 14 of U.N. General Assembly Resolution A/RES/70/1 states the following: "Conserve and sustainably use the oceans, seas and marine resources for sustainable development." ${ }^{, \mathbf{8 3 1}}$ The targets of Goal 14 include the prevention and significant reduction of marine pollution of all kinds, sustainable management and protection of marine and coastal ecosystems, and the minimization of the impacts of ocean acidification. ${ }^{\mathbf{8 3 2}}$ The targets include the effective regulation, by 2020 , of harvesting and ending of overfishing, the conservation of at least 10 percent of coastal and marine areas, and the prohibition of forms of fisheries subsidies which contribute to overcapacity and overfishing. ${ }^{\mathbf{8 3 3}}$

Further, the targets of Goal 14 include the increase, by 2030, of the economic benefits to small island developing States and least developed countries of the sustainable use of marine resources. ${ }^{\mathbf{8 3 4}}$ These targets include increase of scientific knowledge, development of research capacity and transfer of marine technology, in accordance with the Intergovernmental Oceanographic Commission's Criteria and Guidelines on the Transfer of Marine Technology. ${ }^{\mathbf{8 3 5}}$ Finally, the targets include the providing of access for small-scale artisanal fishers to marine resources and markets, and the enhancement of the conservation and sustainable use of oceans and their resources by implementation of international

831. U.N. General Assembly Res. A/RES/70/1, supra note 1, Goal 14.

832. U.N. General Assembly Res. A/RES/70/1, supra note 1, Goal 14, Targets 14.4 - 14.6.

833. U.N. General Assembly Res. A/RES/70/1, supra note 1, Goal 14, Target 14.7.

834. U.N. General Assembly Res. A/RES/70/1, supra note 1, Goal 14, Target 14.a.

835. U.N. General Assembly Res. A/RES/70/1, supra note 1, Goal 14, Targets 14.b - 14.c. 836. International Covenant on Economic, Social, and Cultural Rights (ICESCR), supra note 9, art.11(1) 
law as reflected in the United Nations Convention on the Law of the Sea.

In respect to small island developing States and least developed countries, and small-scale artisanal fishers, the provisions of Goal 14 encompass legally cognizable human rights implied in Article 11(1) of the International Convention on Economic, Social, and Cultural Rights (ICESCR):“" The States Parties to the present Covenant recognize the right of everyone to . . . the continuous improvement of living conditions.",

The provisions of Goal 14 and its targets are in accord with provisions of the International Convention on the Elimination of All Forms of Racial Discrimination ( CERD), Article 2(1) of which states: "States Parties condemn racial discrimination and undertake to pursue by all appropriate means..., a policy of eliminating racial discrimination in all its forms . . ." promoting understanding among all races, . . . .,837

The provisions of Goal 14 are informed by principles of the United Nations Convention on the Law of the Sea (UNCLOS), which recognizes in its Preamble "the desirability of establishing. . . a legal order for the seas and oceans . . . which will promote the peaceful uses of the seas and oceans, the equitable and efficient utilization of their resources, the conservation of their living resources and the study, protection and preservation of the marine environment. ${ }^{838}$

836. U.N. General Assembly Res. A/RES/70/1, supra note 1, Goal 14, Targets 14.b - 14.c. 836. International Covenant on Economic, Social, and Cultural Rights (ICESCR), supra note 9 , art.11(1)

837. International Convention on the Elimination of All Forms of Racial Discrimination CERD), supra note 27, art 2(1).

838. U.N. Convention on the Law of the Sea (1982), supra note 39. 


\section{Analysis of Content of Goal 15}

Goal 15 of U.N. General Assembly Resolution A/RES/70/1 states the following: "Protect, restore and promote sustainable use of terrestrial ecosystems, sustainably manage forests, combat desertification, and halt and reverse land degradation and halt biodiversity loss. ${ }^{, \mathbf{8 3 8}}$ The targets of Goal 15 include the ensuring, by 2020 , of conservation, restoration and sustainable use of terrestrial freshwater ecosystems, promotion of the implementation of sustainable management of forests, and combating of desertification. ${ }^{\mathbf{8 3 9}}$ Further, the targets include the ensuring, by 2030, of the conservation of mountain ecosystems, including their biodiversity. ${ }^{\mathbf{8 4 0}}$ The targets also include urgent and significant action to reduce the degradation of natural habitats, halt the loss of biodiversity and, by 2020, protection and prevention of the extinction of threatened species. ${ }^{\mathbf{8 4 1}}$

In addition, the targets of Goal 15 extend to the promotion of fair and equitable sharing of the benefits arising from the utilization of genetic resources, and urgent action to end poaching and trafficking in protected species of flora and fauna. ${ }^{\mathbf{8 4 2}}$ Further, the targets include the introduction, by 2020, of measures to prevent the introduction of invasive alien species on land and into water ecosystems, and the integration of ecosystem and biodiversity values into national and local planning, development processes. ${ }^{\mathbf{8 4 3}}$ Finally, these targets include

838. U.N. General Assembly Res. A/RES/70/1, supra note 1, Goal 15.

839. U.N. General Assembly Res. A/RES/70/1, supra note 1, Goal 15. Targets 15.1 - 15.3.

840. U.N. General Assembly Res. A/RES/70/1, supra note 1, Goal 15, Target 15.4.

841. U.N. General Assembly Res. A/RES/70/1, supra note 1, Goal 15, Target 15.5 .

842. U.N. General Assembly Res. A/RES/70/1, supra note 1, Goal 15 Targets 15.6 - 15.7.

843. U.N. General Assembly Res. A/RES/70/1, supra note 1, Goal 15, Targets 15.8 - 15.9. 
significant expansion of financial resources to sustainably use biodiversity and ecosystems, support sustainable forest management, and enhanced global support for efforts to combat poaching and trafficking in protected species. ${ }^{\mathbf{8 4}}$

The provisions of Goal 15 encompass legally cognizable human rights implied in Article 11(1) of the International Convention on Economic, Social, and Cultural Rights (ICESCR): ${ }^{845}$

1. The States Parties to the present Covenant recognize the right of of everyone to an adequate standard of living for himself and his family, including adequate food, clothing and housing, and to the continuous improvement of living conditions. The States Parties will take appropriate steps to ensure the realization of this right, recognizing to this effect the essential importance of international co-operation based on free consent.

The relationship between Goal 15, and the human rights articulated in ICESCR Article 11(1) rests in the fact that the rights to an adequate standard of living, and to continuous improvement of living conditions, cannot be realized unless terrestrial and marine ecosystems are preserved.

The ICESCR Committee has cited instances of environmental harm broadly impacting the right to an adequate standard of living: ${ }^{846}$

... . [T]he Committee expressed concern in concluding observations adopted in relation to the Solomon Islands that "the State party does not give due consideration to the threats to the natural

844. U.N. General Assembly Res. A/RES/70/1, supra note 1, Goal 15, Targets 15.a - 15.c.

845. International Covenant on Economic, Social, and Cultural Rights (ICESCR), supra note 9, art. 11(1).

846. See The Committee on Economic, Social, and Cultural Rights, Report on the Twentieth and Twenty-First sessions, 26 April-14 May1999, 15 November-3 December 1999, Economic and Social Council, Official Record, 2000, United Nations, U.N. Doc. E/C.12/1999/11, II 204. 
environment of Solomon Islands, caused by the practices of deforestation and overfishing, affecting the maintenance of an adequate standard of living, as guaranteed by article 11 of the Covenant."

The provisions of Goal 15 and its targets are in accord with provisions of the International Convention on the Elimination of All Forms of Racial Discrimination (CERD), Article 2(1) of which states: "States Parties condemn racial discrimination and undertake to pursue by all appropriate means and without delay a policy of eliminating racial discrimination in all its forms and promoting understanding among all races, . . . ."847

\section{Analysis of Content of Goal 16}

Goal 16 of U.N. General Assembly Resolution A/RES/70/1 states the following: "Promote peaceful and inclusive societies for sustainable development, provide access to justice for all and build effective, accountable and inclusive institutions at all levels., ${ }^{\mathbf{8 4 7}}$ The targets of Goal 16 call for the significant reduction of all forms of violence and related death rates everywhere, the ending of abuse, exploitation, trafficking and all forms of violence against and torture of children, and promotion of the rule of law at the national and international levels to ensure equal access to justice for all. ${ }^{\mathbf{8 4 8}}$

847. U.N. General Assembly Res. A/RES/70/1, supra note 1, Goal 16.

848. U.N. General Assembly Res. A/RES/70/1, supra note 1, Goal 16, Targets 16.1 - 16.3. 
The targets of Goal 16 include significant reduction, by 2030, of illicit financial and arms flows, strengthening recovery and return of stolen assets, and combating of all forms of organized crime; substantial reduction of corruption and bribery in all their forms; and development of effective, accountable and transparent institutions at all levels. ${ }^{849}$ Further, these targets aim for the ensuring of responsive, inclusive, participatory and representative decision-making at all levels; and broadening and strengthening the participation of developing countries in the institutions of global governance. ${ }^{\mathbf{8 5 0}}$

The targets of Goal 16 call for the providing, by 2030, of legal identity for all, including birth registration; and the ensuring of public access to information and protection of fundamental freedoms, in accordance with national legislation and international agreements. ${ }^{851}$ The targets envision strengthening relevant national institutions, including through international cooperation, for building capacity at all levels, to prevent violence and combat terrorism and crime. ${ }^{852}$ Finally, the targets call for the promotion and enforcement of non-discriminatory laws and policies for sustainable development. ${ }^{\mathbf{8 5 3}}$

The terms of Goal 16 generally encompass the entire range of human rights stated in the ICCPR and ICESCR, as indicated by the language of the Preambles to the two Covenants (reproduced below):

849. U.N. General Assembly Res. A/RES/70/1, supra note 1, Goal 16, Targets 16.4-16.6. 850 U.N. General Assembly Res. A/RES/70/1, supra note 1, Goal 16, Targets $16.7-16.8$. 851. U.N. General Assembly Res. A/RES/70/1, supra note 1, Goal 16, Targets 16.9-16.10. 852. U.N. General Assembly Res. A/RES/70/1, supra note 1, Goal 16, Target 16.a.

853. U.N. General Assembly Res. A/RES/70/1, supra note 1, Goal 16, Target 16.b. 


\section{Preamble to the ICCPR: ${ }^{\mathbf{8 5 4}}$}

The States Parties to the present Covenant,

Considering that, in accordance with the principles proclaimed in the Charter of the United Nations, recognition of the inherent dignity and of the equal and inalienable rights of all members of the human family is the foundation of freedom, justice and peace in the world,

Recognizing that these rights derive from the inherent dignity of the human person,

Recognizing that, in accordance with the Universal Declaration of Human Rights, the ideal of free human beings enjoying civil and political freedom and freedom from fear and want can only be achieved if conditions are created whereby everyone may enjoy his civil and political rights, as well as his economic, social and cultural rights,

Considering the obligation of States under the Charter of the United Nations to promote universal respect for, and observance of, human rights and freedoms,

Realizing that the individual, having duties to other individuals and to the community to which he belongs, is under a responsibility to strive for the promotion and observance of the rights recognized in the present Covenant,

Agree upon the following articles:

$\underline{\mathrm{ICESCR}}:^{\mathbf{8 5 5}}$

Preamble

The Preamble to the ICESCR is identical to that to the ICCPR, with the minor exception that the order of the terms in paragraph 4 is reversed.

854. ICCPR, supra note 9, Preamble.

855. ICESCR, supra note 9, Preamble.. 
The provisions of Goal 16 and its targets are in accord with provisions of the International Convention on the Elimination of All Forms of Racial Discrimination (CERD), Article 2(1) of which states: "States Parties condemn racial discrimination and undertake to pursue by all appropriate means and without delay a policy of eliminating racial discrimination in all its forms and promoting understanding among all races, . . ${ }^{\mathbf{8 5 6}}$

\section{$\underline{\text { Analysis of Content of Goal } 17}$}

Goal 17 of U.N. General Assembly Resolution A/RES/70/1 states the following: "Strengthen the means of implementation and revitalize the Global Partnership for Sustainable Development." ${ }^{\mathbf{8 5 7}}$ In the area of finance, the targets of Goal 17 include the strengthening of domestic resource mobilization, full implementation by developed countries of their official development assistance (ODA) commitments, assistance to developing countries in the attainment of long-term debt sustainability, and the adoption of investment promotion regimes to assist least developed countries. ${ }^{\mathbf{8 5 8}}$

In the area of technology, the targets of Goal 17 include the promotion of international cooperation on access to science, technology and innovation, and the enhancement of knowledge-sharing on mutually agreed terms. ${ }^{\mathbf{8 5 9}}$ Further, the targets include the development and transfer of environmentally sound technologies to developing countries on favorable terms, and full operationalization of technology-bank and capacity-building

856. International Convention on the Elimination of All Forms of Racial Discrimination CERD), supra note 27, art 2(1).

857. U.N. General Assembly Res. A/RES/70/1, supra note 1, Goal 17.

858. Id.

859. Id. 
bank and capacity-building mechanisms for least developed countries by $2017{ }^{\mathbf{8 6 0}}$ The technologies to be so targeted include, in particular, those of information and communications. $^{\mathbf{8 6 1}}$

In the area of capacity-building, the targets of Goal 17 include enhancement of international support for implementation of effective and targeted capacity-building in developing countries. ${ }^{\mathbf{8 6 2}}$ It is envisaged that such endeavors will encompass North-South, and triangular cooperation. ${ }^{\mathbf{8 6 3}}$

In the area of trade, the targets of Goal 17 include promotion of a universal, rulesbased,v open, non-discriminatory and equitable multilateral trading system under the World Trade Organization (WTO), through the conclusion of negotiations under its Doha Development vAgenda. ${ }^{\mathbf{8 6 4}}$ Further, it is envisioned that such endeavors will encompass significant increase of the exports of developing countries, and timely implementation of duty-free and quota-free market access on a lasting basis for all least developed countries, consistent with WTO decisions. $^{865}$

In systemic areas, the targets of Goal 17 include enhancement of global macroeconomic stability, policy coherence, and respect for each country's policy space and leadership to establish and implement policies for poverty eradication and sustainable development. ${ }^{866}$ It is envisaged that such efforts will encompass enhancements of Global

860. U.N. General Assembly Res. A/RES/70/1, supra note 1, Goal 17, Targets 17.1-17.19.

861. Id.

862. Id.

863. Id.

864. Id.

865. Id.

866. Id. 
Partnership for Sustainable Development, complemented by multi-stakeholder partnerships. ${ }^{\mathbf{8 6 7}}$ Further, it is envisaged that these endeavors will, by 2030, develop standards of progress on sustainable development that complement gross domestic product (GDP) in developing countries. ${ }^{\mathbf{8 6 8}}$

The provisions of Goal 17 and its targets are in accord with provisions of the International Convention on the Elimination of All Forms of Racial Discrimination (CERD), Article 2(1) of which states: "States Parties condemn racial discrimination And undertake to pursue by all appropriate means and without delay a policy of eliminating racial discrimination in all its forms and promoting understanding among all races, . . . .."869

IIII

The terms of Goal 17 and its targets align with human rights standards stated in the International Convention for Economic, Social, and Cultural Rights (ICESCR), as indicated by the language of the ICESCR's Preamble: ${ }^{\mathbf{8 7 0}}$

The States Parties to the present Covenant,

Considering that, in accordance with the principles proclaimed in the Charter of the United Nations, recognition of the inherent dignity and of the equal and inalienable rights of all members of the human family is the foundation of freedom, justice and peace in the world,

Recognizing that these rights derive from the inherent dignity of the human person,

Recognizing that, in accordance with the Universal Declaration of

867. U.N. General Assembly Res. A/RES/70/1, supra note 1, Goal 17.

868. Id..

869. International Convention on the Elimination of All Forms of Racial Discrimination CERD), supra note 27, art 2(1).

870. International Covenant on Economic, Social, and Cultural Rights (ICESCR), supra note 9, Preamble. 
Human Rights, the ideal of free human beings enjoying freedom from fear and want can only be achieved if conditions are created whereby whereby everyone may enjoy his economic, social and cultural rights, as well as his civil and political rights,

Considering the obligation of States under the Charter of the United Nations to promote universal respect for, and observance of, human rights and freedoms,

Realizing that the individual, having duties to other individuals and to the community to which he belongs, is under a responsibility to strive for the promotion and observance of the rights recognized in the present Covenant,

Agree upon the following articles:

\section{G. Examination and Evaluation of Sustainable Development Goals (SDGs)}

\section{(a) Strengths of the SDG Framework}

The Sustainable Development Goals (SDGs) of U.N. General Assembly Resolution A/RES/70/1 reflect universality of scope and content. ${ }^{871}$ As a notable example, Goal 1, with its urgent mandate on ending poverty in all its forms everywhere, demonstrates concerns extending beyond those related to particular nations or peoples. $^{\mathbf{8 7 2}}$ Further, the SDGs emphasize the need to pay special attention to the poor and vulnerable. ${ }^{873}$ The Targets in Goals 1 and 2, directed to ending conditions of poverty and hunger, refer particularly to the poor and those in vulnerable situations. ${ }^{874}$

871. Ved P. Nanda, The Journey from the Millennium Development Goals to the Sustainable Development Goals, 44 Denv. J. Int'l L. \& Pol'y 389 (2015-2016), supra note 82, at 410. 872. Id. 873. Id. 874. Id. 
In significant contrast to the Millennium Development Goals (MDGs) of 2002, Target 3.7 in Goal 3 of the SDGs states: "By 2030, ensure universal access to sexual and reproductive health-care services, including for family planning, information and education, and the integration of reproductive health into national strategies and programmes." ${ }^{875}$ Goal 4 of the SDGs calls for quality education and learning opportunities for all. ${ }^{876}$ Target 4.1 (under Goal 4) calls for ensuring (by 2030) that "all girls and boys complete free, equitable and quality primary and secondary education leading to relevant and effective learning outcomes." ${ }^{877}$

In several instances where the MDGs were either silent or vague, the SDGs present positive mandates, as indicated in the material that follows. Goal 5 aims for the achievement of gender equality and empowerment for all women and girls. ${ }^{878}$ The Targets of Goal 5 call for ending all forms of discrimination against all women and girls everywhere, eliminating "all forms of violence against all women and girls in the public and private spheres," and eliminating "all harmful practices, such as child, early and forced marriage and female genital mutilation." ${ }^{879}$

Target 6.1 calls for achieving "universal and equitable access to safe

875. Ved P. Nanda, The Journey from the Millennium Development Goals to the Sustainable
Development Goals, 44 Denv. J. Int'l L. \& Pol'y 389 (2015-2016),
supra note 82, at 410.
876. Id.
877. Id.
878. Id.
879. Id.


and affordable drinking water for all., ${ }^{\mathbf{8 8 0}}$ Goal 7, a new addition in the SDGs (relative to the MDGs) calls for the ensuring of access to affordable, reliable, sustainable and modem energy for all. ${ }^{879}$ Goal 8 calls for promoting "sustained, inclusive and sustainable economic growth, full and productive employment and decent work for all."

Within Goal 10, which calls for the reduction of inequality nationally and internationally, Target 10.2 aims for the empowerment and promotion of "the social, economic, and political inclusion of all peoples, irrespective of age, sex, disability, race, ethnicity, origin and religion or economic or other status." ${ }^{\mathbf{8 8 1}}$ Target 13.2 calls for the integration of "climate change measures into national policies, strategies and planning." ${ }^{\mathbf{8 8 2}}$ Target 13.3 focuses on the improvement of "education, awareness-raising and human and institutional capacity, on climate change mitigation, adaptation, impact reduction and early warning." ${ }^{\mathbf{8 8 3}}$

Goal 16 contains provisions that seek to foster the development of peaceful and inclusive societies, with access to justice for all, and effective, accountable and inclusive institutions at all levels. ${ }^{\mathbf{8 8 4}}$ Target 16.3 appropriately calls for promotion of the rule of law at both national and international levels, and the attainment of equal access to justice

879. Ved P. Nanda, The Journey from the Millennium Development Goals to the Sustainable Development Goals, 44 Denv. J. Int'l L. \& Pol'y 389 (2015-2016), supra note 82, at 410. 880. Id.

881. Id. at 410-411.

882. Ved P. Nanda, The Journey from the Millennium Development Goals to the Sustainable Development Goals, 44 Denv. J. Int'l L. \& Pol'y 389 (2015-2016), supra note 82, at 411. 883. Id. 884. Id. 
for all. ${ }^{\mathbf{8 8 5}}$ Target 16.7 seeks to ensure "responsive, inclusive, participatory and representative decision-making at all levels." ${ }^{\mathbf{8 8 6}}$ Target 16.8 calls for broadening and strengthening of the roles of developing nations in processes of global governance. ${ }^{\mathbf{8 8 7}}$

Goal 17, the SDG that addresses issues of global partnership and implementation, contains significantly more detail than its counterparts in the the Millennium Development Goals (MDGs) of 2002. ${ }^{\mathbf{8 8 8}}$ The targets of Goal 17 encompass such varied subjects as finance, technology, capacity building, trade, and several systemic issues such as policy and institutional coherence, multi-stakeholder partnerships, and data, monitoring, and accountability. ${ }^{\mathbf{8 8 9}}$ Goal 17 is substantively based on provisions and terms of the Addis Ababa Action Agenda, which was adopted by Heads of State in July 2015, at the Third International Conference on Financing for Development in Addis Ababa, Ethiopia, and subsequently endorsed by the United Nations General Assembly. ${ }^{\mathbf{8 9 0}}$

(b) Deficiencies of the SDG Framework \& Suggestions for Enhancements to Facilitate Implementation Strategies

A report of the International Council for Science (ICSU), in partnership with the International Social Science Council (ISSC), ${ }^{\mathbf{8 9 1}}$ has observed that the

885. Ved P. Nanda, The Journey from the Millennium Development Goals to the Sustainable Development Goals, 44 Denv. J. Int'1 L. \& Pol'y 389 (2015-2016), supra note 82 , at 411 .

886. Id.

887. Id.

888. Id.

889. Id.

890. Id.

891. ICSU, ISSC (2015): Review of the Sustainable Development Goals: The Science Perspective. Paris: International Council for Science (ICSU), at 8 https://www.icsu.org/cms/2017/05/SDG-Report.pdf 
ultimate end' of the Sustainable Development Goals (SDGs), and the projected contributions of individual goals and targets to the attainment of that end had not been clearly articulated in the SDG framework. ${ }^{\mathbf{8 9 2}}$ The ICSU/ ISSC Report recommended the deployment of a more scientific approach in the framework, stressing that such an approach could enable a more systematic demarcation between ultimate goals and enabling means or conditions. ${ }^{\mathbf{8 9 3}}$ Further, the Report has suggested that more technical work, using methods such as scenario analysis, was needed to demonstrate the ways in which implementation of goals could induce social change, and the degree to which emerging pathways could contribute to the socioeconomic development of individual nations. ${ }^{\mathbf{8 9 4}}$

The SDG framework reflects shared interest and responsibilities for addressing global challenges by governments at the nation-state level. ${ }^{\mathbf{9 9 5}}$ However, governments represent only one category of the actors in global governance today. ${ }^{\mathbf{8 9 6}}$ The SDG framework does not sufficiently reflect and address the roles that many other groups within society will be required to play in the realization of the goals. For instance, it largely fails to reflect private sector perspectives and incentives to participate in the delivery of the goals. ${ }^{\mathbf{8 9 7}}$

892. $I d$. 893. Id. 894. Id. 895. Id. 896. Id.

897. ICSU, ISSC (2015): Review of the Sustainable Development Goals, supra note 889 , at 8-9. 
The goals of the SDG framework are presented using a "silo" approach. ${ }^{\mathbf{8 9 8}}$ The goals are addressed as separate elements, mostly in isolation from each other. ${ }^{\mathbf{8 9}}$ However, it is clear that goal areas overlap, that many targets might contribute to several goals, and that some goals may conflict with others. ${ }^{\mathbf{9 0 0}}$ Further, the goals are presented without reference to possible inter-goal linkages. ${ }^{901}$ Since the SDG framework in its totality does not reflect interlinkages and cannot ensure that development takes place within sustainable levels of resource use at either the global or regional scale, it is possible that adjustments may be required in the processes of implementation. ${ }^{\mathbf{9 0 2}}$ The remedial measures proposed in the following material should be viewed in this light.

\section{Goal 1 (SDG 1): "End Poverty in}

All its Forms Everywhere",903

Works of scientific literature on the relationships between the factors of sustainability, climate variability, and issues of poverty suggest that the targets of SDG 1 should be at the center of all other targets, in order to avoid (a) inequitable transition to a lowcarbon future; and (b) exploitation of the plight of the poor as a means of preventing

898. ICSU, ISSC (2015): Review of the Sustainable Development Goals, supra note 889 , at 9 .

899. Id.

900. ICSU, ISSC (2015): Review of the Sustainable Development Goals, supra note 889 , at 9 .

901. Id.

902. ICSU, ISSC (2015): Review of the Sustainable Development Goals, supra note 889, at 9.

903. U.N. General Assembly Resolution A/RES/70/1, supra note 1, Goal 1.

904. ICSU, ISSC (2015): Review of the Sustainable Development Goals supra note 889, at 9. 
change toward a sustainable future. ${ }^{904}$ Most of the targets of SDG 1 are reasonable bases for improvement, but some may require modified language to enhance measurability. ${ }^{905}$

Further, there is a need for targets of SDG 1 to be so formulated as to promote the adoption of policies that have been proved by methods of social analysis to be more likely to secure poverty reduction. ${ }^{906}$ By this criterion, it is suggested that Target 1.3 ("implementation of nationally appropriate social protection systems and measures for all”) be identified as a primary target. ${ }^{\mathbf{9 0 7}}$ Since SDG 1 is a fundamental goal, the authors of the ICSU/ISSC Report have recommended the addition of language to all other SDGs to state the imperative need to avoid trade-offs between poverty-eradication and sustainability. ${ }^{908}$ Thus, SDG 1 is directly and indirectly related to all other SDGs, but is especially dependent on immediate and substantial progress towards Goals 2, 3, 4, 5, 6, 8, 10, 13 , 16 and $17 .^{909}$

905. Id.

906. Id.

907. Id.

908. ICSU, ISSC (2015): Review of the Sustainable Development Goals, Targets 14.1 - 14.3. supra note 889 , at 17 .

909. Id. 


\section{Goal 2 (SDG 2): "End Hunger, Achieve Food Security, \& Improved Nutrition, and Promote Sustainable Agriculture",910}

Goal 2 (SDG 2) is supported by substantial scientific evidence, since human development requires food security and nutritional improvement, and environmental factors are critical for the development of sustainable agriculture. ${ }^{911}$ However, the attainment of this goal is complicated by the fact that it couples natural biophysical processes with social and economic processes, and because there is currently insufficient evidence on approaches by which food security and nutrition strategies can be successfully scaled up. ${ }^{912}$

There are strong interlinkages between SDG 2 and the other SDGs, since many of the targets of SDG 2 contribute to other SDGs, while some targets under other SDGs contribute to reducing hunger, improving food, nutrition security, and enhancing sustainable agriculture. ${ }^{913}$ In general, SDG 2 moves in concert with Goals 1, 3, 4, 5, 10, and 12; but there are likely to be tensions and trade-offs between this goal and the environmentally focused targets of Goals 6, 7, 13, 14, and $15 .^{914}$ These tensions and trade-offs will need to be explored at an early stage in implementation to ensure that their costs are kept to a minimum. ${ }^{915}$

910. U.N. General Assembly Resolution A/RES/70/1, supra note 1, Goal 2.

911. Id. at 19.

912. II. at 19.

913. Id. at 21.

914 ICSU, ISSC (2015): Review of the Sustainable Development Goals, supra note 889 , at 21 .

915. Id. 


\section{Goal 3 (SDG 3): "Ensure Healthy Lives \&}

Promote Well-Being for All at all Ages." 916

The areas of concern of this goal (SDG 3) cover non-communicable diseases, mental health, disease prevention, tobacco control, disaster risk reduction, and intellectual property. ${ }^{917}$ Seemingly missing elements include recognition of the causative roles in these problems of the global food system, built environment, and socioeconomic factors such as education, working conditions, and occupational health, all of which are factors in the global disease burden. ${ }^{918}$ These issues could be addressed through stronger links of Goal 3 with Goals $4,8,10,11,12$, and $16^{919}$

The targets of SDG 3 appear fragmented, and recognition of the need for country-specific baselines seems missing in many targets. ${ }^{\mathbf{9 2 0}}$ General concerns include: (I) failure to identify life-expectancies and inequalities between and within nations; (II) disharmony in language, in that the separate albeit complementary roles of 'prevention' and 'adequate response/treatment' for human health deserves greater emphasis; (III) the need for greater clarity on aspects of health treated as an input to sustainable development and aspects in which it is a desired outcome that provides a measure of sustainable development; (IV) the need to consolidate physical, social and economic factors, since a large

916. U.N. General Assembly Resolution A/RES/70/1, supra note 1, Goal 3.

917. ICSU, ISSC (2015): Review of the Sustainable Development Goals, supra note 889 , at 23 .

918. Id.

919. Id.

920. Id. 
body of evidence shows these are important determinants of health and wellbeing;

(V) the need for country-specific assessments to identify the most urgent

priorities, such as infectious diseases and malnutrition, or a rise in non-

communicable diseases and obesity; (VI) a need to identify community

engagement and acknowledge political feasibility; (VII) recognition of the role of

rapid unplanned urbanization, internal migration from rural to urban areas,

disasters and climate change impacts; and (VIII) the consequences for SDGs of

demographic (youth/age) changes in emerging nations. ${ }^{\mathbf{9 2 1}}$

From the perspectives of disease prevention and health promotion,

improvement areas of all other goal will contribute to health improvements. ${ }^{\mathbf{9 2 2}}$

This is especially true of SDG 10 , since socioeconomic inequalities are directly

related to health inequalities. ${ }^{\mathbf{9 2 3}}$ Other goals with clear links to health are SDGs 1 ,

$2,5,6,7,8,11,12$ and 16 . Some of the targets under these other goals could be

consolidated with targets under SDG $3 .^{\mathbf{9 2 4}}$

921. ICSU, ISSC (2015): Review of the Sustainable Development Goals, supra note 889 , at 23 .

922. Id. at 25 .

923. Id. at 25 .

924. ICSU, ISSC (2015): Review of the Sustainable Development Goals, supra note 889 , at 25 . 


\section{Goal 4 (SDG 4): "Ensure Inclusive \& Equitable \\ Quality Education and Promote Life-Long \\ Learning Opportunities for All .,925}

It is suggested that Goal 4 (SDG 4) would benefit significantly in its implementation from language to reflect the fact that most educational policies and programs do not as yet reflect the purposes and goals of sustainable development, and some even exacerbate sustainability issues. ${ }^{\mathbf{9 2 6}}$ Further, it is recommended here that, in its implementation, SDG 4 be revised as follows: "Ensure inclusive and equitable quality education and promote life-long learning and opportunities for all, and further, review and reform the purposes, methods, and values that underpin all education and training policies and programs with a view to reinforcing the integration of culturally relevant education for sustainable development as a critical means of assuring a more sustainable future."927

It is suggested that the targets of SDG 4 should reflect more closely the carefully developed five "priority action areas" that UNESCO has set out as part of its "Roadmap for Implementing the Global Action Program on Education for Sustainable Development [ESD]” (UNESCO 2014)..$^{\mathbf{9 2 8}}$ Among other targets, these include "increasing the capacities of educators and trainers to more effectively deliver ESD" and "at community level, scale up ESD programs and multi-stakeholder ESD networks".929

925. U.N. General Assembly Resolution A/RES/70/1, supra note 1, Goal 4.

926. ICSU, ISSC (2015): Review of the Sustainable Development Goals, supra note 889 , at 27 .

927. Id.

928. Id.

929. ICSU, ISSC (2015): Review of the Sustainable Development Goals, supra note 889 , at 27 . 


\section{Goal 5 (SDG 5): "Achieve Gender Equality, and Empower All Women and Girls."}

The authors of the ICSU/ISSC Report (hereinafter "The Report") observe that women and girls continue to face discrimination across economic, social and political spheres and that entrenched gender disparities remain a major cause of poverty and inequality. ${ }^{\mathbf{9 3 1}}$ The Report states that SDG 5 should promote sociopolitical transformation at local, national and global levels, and notes that it would benefit also from a focus on the boy child who is vulnerable in some societies to withdrawal from education, enforced labor, and sexual abuse and trafficking. ${ }^{\mathbf{9 3 2}}$

The Report notes that the targets of SDG 5 lack outcome statements, time specificity, references to women's engagement in wage work, the need for equal access to education, the elimination of gender disparities in education, and women and children's mental and physical health beyond that of reproduction. ${ }^{\mathbf{9 3}}$

Since gender-related inequalities are among the most pervasive and apparently intractable forms of inequalities, the Report indicates strong interlinkages between this goal and the other SDGs. ${ }^{\mathbf{9 3 4}}$ The Report recommends the addition of language to implementation provisions to recognize that without attention to gender-based inequalities, sustainable change is unlikely to be realized. ${ }^{935}$

930. U.N. General Assembly Resolution A/RES/70/1, supra note 1, Goal 5.

931. ICSU, ISSC (2015): Review of the Sustainable Development Goals, supra note 889 , at 31 .

932. Id.

933. Id

934. ICSU, ISSC (2015): Review of the Sustainable Development Goals, supra note 889 , at 33 .

935. Id. 


\section{Goal 6 (SDG 6): "Ensure Availability \& Sustainable}

\section{Management of Water and Sanitation for All.",936}

The authors of the ICSU/ISSC Report (hereinafter, “The Report”) observe that, while the targets of SDG 6 are supported by the findings of science, some targets appear unduly ambitious or ambiguous, because they fail to specify the proportions of particular populations that should be benefitted by the year $2030 .{ }^{\mathbf{9 3 7}}$ Others involve multiple issues which do not appear to be clearly related. ${ }^{\mathbf{9 3 8}}$

The Report states in summary that the targets of SDG 6 should be consolidated around three primary objectives: (I) water, sanitation and health; (II) reducing pollutant and untreated waste water discharge into rivers and water bodies; and (III) reducing water scarcity by protecting water sources, increasing the efficiency of water use, and better governance.. ${ }^{939}$ Governance measures could include establishing a water rights/permits framework tailored to each nation's particular needs, that would harmonize decisions related to water. ${ }^{\mathbf{9 4 0}}$ The Report adds that this goal is linked directly or indirectly with targets in each of the other SDGs. ${ }^{941}$ In particular, it has strong links with SDGs 2, 3, 5, 7, 12, 13,14 and $15 .^{942}$

936. U.N. General Assembly Resolution A/RES/70/1, supra note 1, Goal 6.

937. ICSU, ISSC (2015): Review of the Sustainable Development Goals, supra note 889 , at 35 .

938. Id.

939. Id.

940. Id.

941. ICSU, ISSC (2015): Review of the Sustainable Development Goals, supra note 889 , at 37 .

942. Id. 


\section{Goal 7 (SDG7): "Ensure Access to Affordable,}

Reliable, Sustainable, \& Modern Energy for All."

The authors of the ICSU/ISSC Report (hereinafter, “The Report”) suggest that optimal outcomes in this area require greater specificity in the designations of the types and the level of energy services to which all people should have access. ${ }^{944}$ While the overall assessment is that SDG 7 adequately addresses the economic ('affordable'), social ('reliable' and 'modern') and environmental ('sustainable') aspects of energy access, it is suggested that a fourth target (Target 7.4) be added to implementation plans, stated as follows: "Ensure by 2030 access to all to energy carriers and/or energy consuming devices that keep indoor air and other local pollution levels within safe limits." The authors of the Report add that Target 7.4 is needed to ensure, "the clean and safe nature of energy usage."945

Energy is a vital resource that is essential to meet other Sustainable Development (SD) goals: primarily health (SDG 3), poverty eradication (SDG 1), climate change (SDG 13), but also to end hunger (SDG 2), foster education (SDG 4), gender equality (SDG 5), clean water and sanitation (SDG 6), productive opportunities (SDG 8), cities (SDG 11), infrastructure/industrialization (SDG 11) and sustainable consumption (SDG 12). ${ }^{946}$ Without attaining SDG 7, it will be impossible to meet these other goals. ${ }^{\mathbf{9 4 7}}$

943. U.N. General Assembly Resolution A/RES/70/1, supra note 1, Goal 7

944. ICSU, ISSC (2015): Review of the Sustainable Development Goals, supra note 889 , at 39 .

945. Id.

946. ICSU, ISSC (2015): Review of the Sustainable Development Goals, supra note 889 , at 41 .

947. Id. 
Goal 8 (SDG 8): "Promote Sustained, Inclusive and

Sustainable Economic Growth, Full and Productive Employment and Decent Work for All."

Groups not mentioned in SDG 8's targets include severely economically disadvantaged sections of the global population, all of whom require stable jobs, social security and pensions. ${ }^{949}$ It is suggested that the rate of growth in each case should be adjusted to take account of inequalities within the particular society. ${ }^{\mathbf{9 5 0}}$

The presence in SDG 8 of the factor of inclusiveness of economic growth creates strong links with SDG 10 and its factor of income inequality. ${ }^{951}$ SDG 8 also has strong links with SDG 7 from both the inclusiveness and greenness perspectives. ${ }^{\mathbf{9 5 2}}$ The factor of global partnership in SDG 17 creates a strong link with sustainability in SDG 8. ${ }^{953}$ A key challenge may be to advise national governments on how to achieve the socioeconomic goals (SDGs 1, 2, 8, and10), while addressing environmental issues in SDGs 13,14 and $15 .^{954}$

Goal 9 (SDG 9): "Build Resilient Infrastructure, Promote Inclusive \& Sustainable Industrialization and Foster Innovation.",955

Goal 9 (SDG 9), in concert with SDGs 11 and 12, aims to ensure that the global economic system is sustainable in terms of resource use and associated

948. U.N. General Assembly Resolution A/RES/70/1, supra note 1, Goal 8.

949. ICSU, ISSC (2015): Review of the Sustainable Development Goals, supra note 889 , at 43 .

950. Id.

951. Id. at 45 .

952. Id. at 45 .

953. Id. at 45 .

954. Id. at 45 .

955. U.N. General Assembly Resolution A/RES/70/1, supra note 1, Goal 9. 
impacts (environmental sustainability), benefits the broadest number of people in society, supports their well-being and development, is affordable, and delivers economic output serving human needs. ${ }^{956}$ The targets of SDG 9 are all relevant, but would benefit from clearer wording, greater quantification, and improved connectivity to other goals. ${ }^{\mathbf{9 5 7}}$

The main concern with SDG 9 is that the concept of 'sustainable infrastructure' is not defined. An additional concern is that this goal is not quantified, and lacks target dates. ${ }^{\mathbf{9 5 8}}$ The three most important links between SDG 9 and other SDGs, (in terms of inter-target linkage), are its relationships with SDGs 11, 12 and $13 .^{\mathbf{9 5 9}}$

\section{Goal 10 (SDG 10): "Reduce Inequality Within and Among Countries."960}

This goal appears to lack specificity, although its targets relate to all dimensions of sustainable development. ${ }^{961}$ A danger is that the inequalities to be reduced could be interpreted as social inequalities, thereby avoiding difficult issues of income and wealth differentials. ${ }^{962}$ The proposed targets of SDG 10 are relevant but inadequately developed, with each target requiring revision to

956. ICSU, ISSC (2015): Review of the Sustainable Development Goals, supra note 889 , at 47 .

957. Id.

958. Id. .

959. Id. at 49.

960. U.N. General Assembly Resolution A/RES/70/1, supra note 1, Goal 10.

961. ICSU, ISSC (2015): Review of the Sustainable Development Goals, supra note 889 , at 51 .

962. ICSU, ISSC (2015): Review of the Sustainable Development Goals, supra note 889 , at 51 . 
provide measurability. ${ }^{\mathbf{9 6 3}}$ If Target 10.1 is revised to include a measurable reduction of economic inequality, this target would be the most important for SDG 10, since the minimization of economic inequalities would assist in the attainment of most other targets. ${ }^{\mathbf{9 6 4}}$

In view of its strategic centrality, Target 10.1 must be articulated as precisely as possible so that it is clear, easily measured, and stands as an ambitious target facilitating progress across the entire sustainable development agenda. ${ }^{965}$ SDG 10 is related to all the other goals, to the extent that no goal can be considered as fully attained unless it has been met equitably for all segments of the particular society. ${ }^{966}$

\section{Goal 11 (SDG 11): "Make Cities and Human Settlements Inclusive, Safe, Resilient, \& Sustainable."}

The increasing dominance of urban centers in the modern world has produced impacts across all aspects and dimensions of global change, and makes intervention at the urban scale imperative to achieve the goals of sustainable development. ${ }^{968}$ Although the targets of SDG 11 appropriately cover all three dimensions of sustainable development, the targets appear to neglect attention to the institutional dimension (especially local government and land and finance

1

963. ICSU, ISSC (2015): Review of the Sustainable Development Goals, supra note 889 , at 51 .

964. Id

965. Id.

966. ICSU, ISSC (2015): Review of the Sustainable Development Goals, supra note 889 , at 53 .

967. U.N. General Assembly Resolution A/RES/70/1, supra note 1, Goal 11.

968. ICSU, ISSC (2015): Review of the Sustainable Development Goals, supra note 889 , at 55 . 
management capacity) that is critical to the attainment of other targets. ${ }^{\mathbf{9 6 9}}$ This is especially true of the developing world where urban challenges are greatest and institutions weakest. ${ }^{970}$

Significant differences in the challenges facing cities and the resources available to deal with them mean that the principles of universality, integration and transformation will have to be applied differentially within and across nations. ${ }^{971}$ The complex social, cultural, economic, environmental, technological, physical, and political realities of urban life require stronger city-focused institutions than ever before, implying the necessity of a degree of devolution of power from nation states to urban centers. ${ }^{\mathbf{9 7 2}}$ Key goals that intersect with SDG 11 are SDGs $1,3,6,7,8,9,10,13$, and $16 .{ }^{973}$

\section{Goal 12 (SDG 12): "Ensure Sustainable Consumption and Production Patterns.",974}

Goal 12 (SDG 12) provides more focus to the economic and environmental dimensions than the social dimension. The targets of SDG 12 require greater quantification, clearer wording, and better connections with other goals. ${ }^{975}$ SDG 12 is closely linked with other goals relevant to basic needs and improving

969. ICSU, ISSC (2015): Review of the Sustainable Development Goals, supra note 889 , at 55 .

970. Id.

971. Id.

972. Id.

973. ICSU, ISSC (2015): Review of the Sustainable Development Goals, supra note 889 , at 57.

974. U.N. General Assembly Resolution A/RES/70/1, supra note 1, Goal 12.

975. ICSU, ISSC (2015): Review of the Sustainable Development Goals, supra note 889 , at 59 . 
quality of life. $^{\mathbf{9 7 6}}$ The targets of SDG 12 are mostly based on developed-nation patterns of consumption and production, which are not applicable to developing nations. ${ }^{\mathbf{9 7 7}}$ New metrics for monitoring progress will require innovative approaches for closing the resource loop to promote product re-use, re-manufacturing, and recycling. ${ }^{978}$

\section{Goal 13 (SDG 13): "Take Urgent Action to Combat Climate Change and its Impacts."}

The Fifth Assessment Report (AR5) of the Intergovernmental Panel on Climate Change (IPCC) notes that the various impacts of climate change constitute a major risk for all dimensions of sustainable development. ${ }^{980}$ Further, actions undertaken to mitigate and adapt to climate change are likely to have significant implications for most dimensions of sustainable development. ${ }^{\mathbf{9 8 1}}$

It is notable that certain policies that have not embodied "climate" considerations have strong implications for both mitigative and adaptive capacity. ${ }^{\mathbf{9 8 2}}$ As an example, urban or fiscal policies impact the physical contours of cities, which, in turn, are key determinants of household demand for transport services, and of the variabilities of different modes of transport. ${ }^{983}$

976. ICSU, ISSC (2015): Review of the Sustainable Development Goals, supra note 889 , at 61 .

977. Id. at 62 .

978. Id.

979. U.N. General Assembly Resolution A/RES/70/1, supra note 1, Goal 13.

980. ICSU, ISSC (2015): Review of the Sustainable Development Goals, supra note 889 , at 63 .

981. Id.

982. Id.

983. Id. 
The United Nations Framework Convention on Climate Change (UNFCCC) has been generally acknowledged to be the primary forum for the global response to climate change. ${ }^{984}$ In regard to matters of climate change, while it is reasonable that SDG 13 does not include quantitative targets as these are part of the UNFCCC negotiations, qualitative enhancements of the targets of SDG 13 are suggested as part of implementation measures. ${ }^{\mathbf{9 8 5}}$

\section{Goal 14 (SDG 14): "Conserve and Sustainably} Use the Oceans, Seas, \& Marine Resources for Sustainable Development." ${ }^{, 986}$

In view of the fact that the oceans and seas cover $70 \%$ of the Earth's surface area, host the largest connected ecosystem, and play a central role in climate stability, oxygen generation, nutrient cycling, food production and coastal protection, SDG 14 is ambitious, timely and supported by a significant body of natural and social science. ${ }^{987}$ Globally, there is a growing dependency on the significant ecosystem services provided by these systems, including the transportation of goods; food through fisheries and aquaculture; and new uses such as the generation of renewable energy, mining of materials and tourism. ${ }^{\mathbf{9 8 8}}$

The targets of SDG 14 are all relevant, and support sustainable development of the oceans in terms of currently dominant industries. ${ }^{989}$ It is

984. ICSU, ISSC (2015): Review of the Sustainable Development Goals, supra note 889 , at 63 .

985. Id. .

986. U.N. General Assembly Resolution A/RES/70/1, supra note 1, Goal 14.

987. ICSU, ISSC (2015): Review of the Sustainable Development Goals,

988. Id.

989. Id. 
suggested that several targets, particularly Targets $14.1,14.2$, and 14.4 would benefit from clearer wording and better quantification. ${ }^{\mathbf{9 9 0}}$ Further, the current set of targets could be enhanced by the inclusion of a specific social goal on equity, marine spatial planning efforts and improved governance/institutions. ${ }^{\mathbf{9 9 1}}$

This goal has strong synergies with SDGs 6 and 15 in respect to system restoration and quality, but equally there are potential trade-offs with SDG $2 .^{\mathbf{9 9 2}}$ Linkage between goals can be identified according to the ecosystem services provided by the ocean, or through societal transformation processes such as institutions, financing, capacity-building and transparency. ${ }^{\mathbf{9 9 3}}$

\section{Goal 15 (SDG 15): "Protect, Restore, \& Promote Sustainable Use of Terrestrial Ecosystems, Sustainably Manage Forests, Combat Desertification, and Halt and Reverse Land Degradation and Halt Biodiversity Loss. .994}

Biodiversity and terrestrial ecosystems are essential for providing ecosystem services and benefits to human society. ${ }^{995}$ Biodiversity and ecological processes enhance the Earth's capacity to absorb and respond to disturbances and environmental change. ${ }^{996}$ Biodiversity also has important spiritual, educational,

990. ICSU, ISSC (2015): Review of the Sustainable Development Goals, supra note 889 , at 67.

991. Id.

992. Id.

993. Id. at 69.

994. U.N. General Assembly Resolution A/RES/70/1, supra note 1, Goal 15.

995. ICSU, ISSC (2015): Review of the Sustainable Development Goals, supra note 889 , at 71 .

996. Id. 
aesthetic, and inspirational values. ${ }^{\mathbf{9 9 7}}$

The targets of SDG 15 appear to prioritize certain issues relative to others, and thereby to create imbalances. ${ }^{998}$ It is suggested that such imbalances be appropriately adjusted to ensure a uniform perspective for terrestrial ecosystems. ${ }^{999}$

Biodiversity is an important factor in all aspects of human wellbeing. ${ }^{1000}$ Accordingly, SDG 15 is strongly linked to all other SDGs, and sound ecological management is required, to ensure higher-quality flows of ecosystem services. $^{1001}$

Goal 16 (SDG 16): "Promote Peaceful and Inclusive Societies for Sustainable Development, Provide Access to Justice for All, \& Build Effective, Accountable, \& Inclusive Institutions at All Levels..$" 1002$

Goal 16 (SDG 16) concerns three elements: peace; just and inclusive societies; and effective, accountable and inclusive institutions. ${ }^{\mathbf{1 0 0 3}}$ This goal is strongly linked to all the other goals in the SDG Framework, because peace, justice, inclusion and accountability, and appropriate institutions, strongly influence all other factors of the Framework. ${ }^{1004}$ The goal is especially strongly

997. ICSU, ISSC (2015): Review of the Sustainable Development Goals, supra note 889 , at 71 .

998. Id.

999. Id.

1000. ICSU, ISSC (2015): Review of the Sustainable Development Goals, supra note 889 , at 73 .

1001. Id.

1002. U.N. General Assembly Resolution A/RES/70/1, supra note 1, Goal 16.

1003. ICSU, ISSC (2015): Review of the Sustainable Development Goals, supra note 889 , at 75 .

1004. ICSU, ISSC (2015): Review of the Sustainable Development Goals, supra note 889 , at 77 . 
linked to SDG 1 (poverty reduction), SDG 4 (equitable education), SDG 5 (gender equality), SDG 9 (resilient infra-structure), and SDG 17 (means of implementation). ${ }^{1005}$

Goal 17 (SDG 17): "Strengthen the Means of Implementation, \& Revitalize the Global Partnership, for Sustainable Development."1006

This goal contains key enablers to facilitate action across the entire range of the SDG Framework. ${ }^{1007}$ Its targets must, therefore, be closely aligned with the post-2020 climate change regime, the Doha Development Agenda of the World Trade Organization (WTO), and financing for development processes. ${ }^{1008}$ Further, the targets must support universal principles of human rights, so that trade, financing and other related processes actively promote rights. ${ }^{1009}$

The targets, across the SDG Framework, are generally evaluated by the five factors of the "SMART" criteria - specific, measurable, attainable, relevant, and time-bound. ${ }^{1010}$ The targets should also cohere with, and be consistent with standards established by existing national and international agreements. ${ }^{1011}$

1005. ICSU, ISSC (2015): Review of the Sustainable Development Goals, supra note 889 , at 77 .

1006. U.N. General Assembly Resolution A/RES/70/1, supra note 1, Goal 17.

1007. ICSU, ISSC (2015): Review of the Sustainable Development Goals, supra note 889 , at 79 .

1008. Id.

1009. Id.

1010. Id.

1011. Id. 


\section{(c) Overall Assessment of the SDG Framework}

Among the major improvements offered by the Sustainable Development Goals (SDGs) over the Millennium Development Goals (MDGs) are remedial measures aimed at certain systemic barriers overlooked in the MDGs. ${ }^{1012}$ These barriers involve such issues as societal inequalities, unsustainable consumption patterns, weak institutional capacity, and environmental degradation. ${ }^{1013}$

A shortcoming observable in the SDG framework is the absence of an overall plan coordinating the paths by which the goals must be implemented to achieve improved general outcomes. ${ }^{1014}$ As part of the response to this shortcoming, it has been suggested that an overarching goal could be formulated, for instance, binding together the 17 SDGs, and thereby creating a clearer means-to-end continuum. ${ }^{1015}$

The current SDG framework does not identify the wide range of social groups that will need to be integrated into its implementation processes to advance goals as agents of change alongside governments. ${ }^{1016}$ Further, there is a need to identify relationships, linkages, and complementarities among goals and targets, in order to suitably integrate such components into implementation processes. ${ }^{1017}$

1012. ICSU, ISSC (2015): Review of the Sustainable Development Goals, supra note 889 , at 5 .

1013. Id.

1014. Id.

1015. Id.

1016. Id.

1017. ICSU, ISSC (2015): Review of the Sustainable Development Goals, supra note 889 , at 5 . 
Many of the targets may also contribute to multiple goals, and some goals and targets may be involved in conflict. ${ }^{\mathbf{1 0 1 8}}$ For example, the ending of poverty (SDG 1) cannot be achieved without progress on the food security target under SDG 2, full and productive employment and decent work under SDG 8, the reduction of inequality under SDG 10 , and the enhancing of resilience to climate change under SDG 13. ${ }^{1019}$ Progress in the foregoing areas will lead to enhanced general standards of health, and will thereby contribute to SDG $3 .^{\mathbf{1 0 2 0}}$

There are also important and difficult tradeoffs between certain targets. ${ }^{1021}$ For example, an increase in agricultural land-use in an attempt to end hunger can result in biodiversity loss, as well as in depletion of water resources and negative effects on marine resources, which in turn could decrease food availability. ${ }^{\mathbf{1 0 2 2}}$

A number of targets in the SDG Framework have not been quantified. ${ }^{\mathbf{1 0 2 3}}$ Key indicators may need to be developed to support a system for monitoring and review of implementation processes. ${ }^{\mathbf{1 0 2 4}}$ In general, measurability of outcomes will depend on the availability of data and the capacity to measure targets. ${ }^{\mathbf{1 0 2 5}}$ Issues are presented in regard to the capacity to collect reliable data at the national level consistently across member states, and the availability of data and agreed-

1018. ICSU, ISSC (2015): Review of the Sustainable Development Goals, supra note 889 , at 6 .

1019. Id.

1020. Id.

1021. Id.

1022. Id.

1023. ICSU, ISSC (2015): Review of the Sustainable Development Goals, supra note 889 , at 7 .

1024. Id.

1025. Id. 
upon definitions to enable comparison. ${ }^{\mathbf{1 0 2 6}}$ Further, the veracity of some existing indicators will need to be confirmed before they are relied upon for performance assessment. ${ }^{1027}$ As part of the process, it will be necessary to generate baselines that are appropriate to specific countries. ${ }^{\mathbf{1 0 2 8}}$

\section{Conclusion}

Under the provisions of Articles 55(c) and 56 of the U.N. Charter, each Member State of the United Nations, by becoming a party to the Charter, has accepted legal obligations in the effort to promote universal respect for, and observance of, human rights and fundamental freedoms for all without distinction as to race, sex, language, or religion. ${ }^{1029}$ Further, eminent jurist, Mr. Hersch Lauterpacht, has observed that in issues, such as those of human rights - a constant and fundamental theme of the U.N. Charter - the provisions of the Charter impose legal obligations upon both the Members of the United Nations and the United Nations as a whole..$^{1030}$

Preceding material in this study presented arguments that the Sustainable Development Goals (SDG's) of U.N. General Assembly Resolution A/RES/70/1 encompass legally cognizable human rights, grounded in provisions and

\footnotetext{
1026. ICSU, ISSC (2015): Review of the Sustainable Development Goals, supra note 889 , at 7 .

1027. Id.

1028 Id.

1029. U.N. CHARTER art. 55(c), U.N. CHARTER art. 56.

1030. LAUTERPACHT, supra note 662, at 159.
} 
principles of the U.N. Charter and International Bill of Human Rights. ${ }^{1031}$

It follows, therefore, that both Member States and the United Nations as a whole have legal obligations in regard to the implementation of the provisions of General Assembly Resolution A/RES/70/1, with its framework of Sustainable Development Goals. The only issues to be resolved in the matter are in the means, manner, and methods by which the legal obligations so implied should be discharged.

In view of the critical importance and vast range of its objectives, and the fact that it was adopted without a single opposing vote, Resolution A/RES/70/1 must be considered one of the great accomplishments of the U.N. General Assembly. However, as indicated in preceding material in this study, it is undeniable that Resolution A/RES/70/1 has shortcomings and flaws that will raise major challenges in its implementation. ${ }^{\mathbf{1 0 3 2}}$

Challenges that will have to be met in implementing Resolution $\mathrm{A} / \mathrm{RES} / 70 / 1$ will include those in the technological, financial, and managerial areas. A major undertaking that will be necessary, will be the task of conveying to the world community of sovereign, independent nations the imperative necessity of international collaboration in all matters relating to implementation of the provisions of Resolution A/RES/70/1. In a world whose primary ethos is that of international competition and rivalry, that undertaking will require great

1031 See supra notes 714-866.

1032 See supra notes 889-1026. 
reserves of diplomatic skill and a comprehensive understanding of the larger issues of life. Colossal tasks, such as control of climate change and prevention of environmental degradation, elimination of conditions of poverty, and ending of societal inequities, will prove impossible of realization without international collaboration on a scale not hitherto witnessed in human history.

In light of the United Nations' unique stature, and, in particular, its legally cognizable obligations in regard to Resolution A/RES/70/1, it would seem essential that the U.N. and its leadership, in particular, the Secretary-General (who is designated Head of the U.N. Organization), should play an executive leadership role in implementation of its provisions. Details of these, and other suggestions for possible approaches to implementation of Resolution A/RES/70/1 will be presented in Part IV of this study. 


\section{IMPLEMENTATION OF SUSTAINABLE DEVELOPMENT}

\section{A. Introduction}

Part IV of this study examines possibilities and potentialities in the implementation of measures to enable the realization of the 17 goals and 169 targets of United Nations General Assembly Resolution A/RES/70/1, “Transforming Our World: the 2030 Agenda for Sustainable Development."1033

Part IV begins with a survey of technological innovations designed to eliminate, or significantly mitigate, environmental degradation caused by power generation. industry, transportation, and other processes. It then proceeds to a review of governmental programs (primarily Official Development Assistance, “ODA,”) set up to promote economic growth and foster social development. Finally, Part IV examines possibilities for the role of executive leader of an international, collaborative initiative for Sustainable Development.

In view of the worldwide scope of the project, and the unprecedented nature of the challenges it faces, the Secretary-General of the United Nations must be considered the logical choice for the role of its executive leader. Accordingly, the history of the evolution of the complex and multi-dimensioned position of U.N. Secretary-General will be examined in this study, to develop a sense of possibilities of future major expansion and development of the executive aspects of the office, that will be required, to meet the demands and exigencies of the Sustainable Development Initiative, without violating the principles of the U.N. Charter.

1033. United Nations General Assembly Resolution A/RES/70/1, supra, note 1. 


\section{B. Possibilities of Remediation to Achieve SDGs}

An examination of possibilities for resolution of problems of sustainable development indicates the need for issues to be addressed at multiple levels scientific, technological, and political. This section will suggest that among the most important issues to be resolved at a preliminary stage are those involving differences in viewpoint within the scientific community as to the purported existence and causes of anthropogenic climate change.

\section{(1) An Essential Preliminary Step to Resolving Controversies}

The position of the Intergovernmental Panel on Climate Change (IPCC)

on the primary questions of climate change is summarized as follows:

Warming of the climate system is unequivocal, and since the 1950s, many of the observed changes are unprecedented over decades to millennia. The atmosphere and ocean have warmed, the amounts of snow and ice have diminished, and sea level has risen. ${ }^{\mathbf{1 0 3 4}}$

Anthropogenic greenhouse gas emissions have increased since the pre-industrial era, driven largely by economic and population growth, and are now higher than ever. This has led to atmospheric concentrations of carbon dioxide, methane and nitrous oxide that are unprecedented in at least the last 800,000 years. Their effects, together with those of other anthropogenic drivers, have been detected throughout the climate system and are extremely likely to have been the dominant cause of the observed warming since the mid-20th century. ${ }^{1035}$

However, there are notable voices in opposition to the viewpoint of the

IPCC. Part IV of this study presents the positions of significantly qualified individuals who have expressed doubt that anthropogenic activities, processes, and substances have a significant impact on climate change. The names and

1034. IPCC, 2014: Climate Change 2014: Synthesis Report, supra note 147.

1035. Id. at 4 
professional affiliations of these individuals are as follows:

1. Professor Ian Plimer, Emeritus Professor of Earth Sciences at the University of Melbourne, and Professor of Mining Geology at the University of Adelaide ${ }^{1036}$

2. Dr. Richard S. Lindzen, Atmospheric Physicist, former Professor of Meteorology at the Massachusetts Institute of Technology (MIT), and lead author of Chapter 7, "Physical Climate Processes and Feedbacks," of the Intergovernmental Panel on Climate Change's (IPCC's) Third Assessment $\underline{\text { Report (2001); }} ;{ }^{1037}$

3. Professor Garth W. Paltridge, Emeritus Professor at the Institute of Antarctic and Southern Oceans Studies (IASOS), University of Tasmania; ${ }^{1038}$

4. Mr. Patrick J. Michaels, Director of the Center for the Study of Science at the Cato Institute, Washington DC; ${ }^{1039}$

5 Mr. Kesten C. Green, Senior Research Associate of the Ehrenberg-Bass Institute, University of South Australia, and Mr. J. Scott Armstrong, University of Pennsylvania. ${ }^{1040}$

In light of the wide divergence in view on issues of climate change, between members of the scientific community, it is suggested that the Intergovernmental Panel on Climate Change (IPCC) significantly expand and intensify its efforts to facilitate the attainment of world-wide consensus on

1036. Ian Plimer. See supra text accompanying notes 623-625.

1037. Richard S. Lindzen. See supra text accompanying note 626-627.

1038. Garth W. Paltridge. See supra text accompanying notes 628-630.

1039. Patrick J. Michaels. See supra text accompanying note 631.

1040. Kesten C. Green \& J. Scott Armstrong. See supra text accompanying note 632. 
scientific aspects of problems of climate change, and thereby achieve appropriate resolutions of such problems. In view of its neutrality, independence, stature, and resources, the IPCC is uniquely qualified, among organizations, to undertake such endeavors.

\section{(2) Questions of Technological Feasibility}

In view of the gravity and imminence of projected climate changes caused by human-generated materials and processes, the question arises as to whether technological products and processes are available to mitigate these adverse effects. A positive answer to the foregoing question was provided in a 2009 study by Mark Z. Jacobson, Professor of Civil and Environmental Engineering at Stanford University, and Mark A. Delucchi, Research Scientist at the Institute of Transportation Studies at the University of California at Davis. ${ }^{1041}$ The study authored by Jacobson and Delucchi provided a detailed plan for "how 100 percent of the world's energy, for all purposes, could be supplied by wind, water and solar resources, by as early as 2030."1042

Additional studies demonstrating similar potential for rapid progress in the development of non-depleting energy sources include the following:

- The Energy Institute of the University of Melbourne, Australia, and the nonprofit organization, “Beyond Zero Emissions," jointly published a blueprint

1041. NaOmi Klein, This Changes Everything: CAPitalism vs The Climate 101 (2015) (Citing Mark Z. Jacobson \& Mark A. Delucchi, “ A Plan to Power 100 Percent of the Planet with Renewables," SCI. AM., Nov. 2009, at 58-59). 1042. Id. 
for developing a 60 percent solar and 40 percent wind electricity system in 10 years. $^{1043}$

- The U.S. National Oceanic and Atmospheric Administration (NOAA) had concluded, by 2014, from its extensive research into weather patterns, that cost-effective wind and solar-based systems could be developed to supply nearly 60 percent of U.S. electric power requirements by $2030 .^{\mathbf{1 0 4 4}}$

- A major study in 2012 by the U.S. Department of Energy's National Renewal Energy Laboratory argued that wind, solar, and other available "green" technologies could meet 80 percent of U.S. electricity needs by $2050 .^{\mathbf{1 0 4 5}}$

The foregoing material provides reasonable grounds for a general assessment that the state of technology has progressed to the point that materials, products, and processes exist in the modern world to enable a concerted, steadypaced transition from the current non-renewable energy resources, to wind, solar, and other "green" technologies for the generation of all required electric power world-wide.

1043. Id. at 102 (citing Matthew Wright and Patrick Hearps, "Zero Carbon Australia 2020: Stationary Energy Sector Report - Executive Summary" (2nd ed.), University of Melbourne Energy Research Institute and Beyond Zero Emissions, Aug. 2011, at 2,6).

1044. Id. at 102 (citing Alexander MacDonald \& Christopher Clack, "Low Cost and Low Carbon Emission Wind and Solar Energy Systems are Feasible for Large Geographic Domains," - presentation at "Sustainable Energy and Atmospheric Sciences" seminar, Earth System Research Laboratory (ESRL), U.S. National Oceanic and Atmospheric Administration, May 14, 2014).

1045. Id. at 102 (citing M. M. Hand et al., "Renewable Electricity Futures Study - Volume Exploration of High-Penetration Renewable Electricity Futures," National Renewable Energy Laboratory, 2012, at xvii-xviii). 


\section{(3) Official Development Assistance (ODA)}

The experiences of sub-Saharan Africa and South Asia indicate that appropriately directed investments in agriculture, health, education, infrastructure, and women's empowerment can help these regions to free themselves from the ancient scourge of poverty. ${ }^{\mathbf{1 0 4 6}}$ The problem is, however, that individual nations may be too lacking in resources to take the necessary first steps to rise from conditions of poverty. ${ }^{1047}$ An important originating point of the concept of official development assistance (ODA) can be traced to the famous Marshall Plan launched by the United States after World War II to help postwar Europe recover from the devastation of war. ${ }^{\mathbf{1 0 4 8}}$ The immense success of the Marshall Plan provided an inspiration for a growing system of grants and low-interest loans to trigger economic growth, for example, in the newly independent nations of Africa and Asia. ${ }^{1049}$

Official Development Assistance (ODA) was conceived of by the United States and other members of the Organization of Economic Cooperation and Development (OECD) as a temporary measure to help economically disadvantaged nations to make the crucial early investments needed to attain a state of self-sufficiency. ${ }^{\mathbf{1 0 5 0}}$ It has been estimated that graduation from developmental assistance can occur when a recipient nation's Gross Domestic Product (GDP) reaches a level of about $\$ 3,000$ per person per year at international

1046. SACHS, The Age Of Sustainable DeVElopment (2015), supra note 71, at 171.

1047. Id.

1048. Id.

1049. Id.

1050. Sachs, The Age of Sustainable DeVelopment (2015), supra note 71, at 172. 
(purchasing power parity, or PPP) prices. ${ }^{\mathbf{1 0 5 1}}$ During the period of the Millennium Development Goals (MDG), ODA played a major role in helping poor nations to control AIDS, malaria, and tuberculosis, and in helping to ensure that mothers are safe in childbirth, and that newborn children can survive the first days of life. ${ }^{\mathbf{1 0 5 2}}$

Experience indicates that Official Development Assistance (ODA) can make a significant difference when it is operated on a professional basis for the real purpose of development, and is grounded in accurate diagnoses of the needs of recipient low-income nations. ${ }^{\mathbf{1 0 5 3}}$ Mr. Jeffrey D. Sachs, Director of the UN Sustainable Development Solutions observes: "[ODA] comes at very low cost, less than 1 percent of the national income of the donor countries. If the rich world makes that effort, and if the funds are well used, ODA indeed can help to ensure that we are the generation that ends extreme poverty."1054

\section{(4) Summation of Issues in Regard to Remedial Possibilities}

This section suggests that the Intergovernmental Panel on Climate Change (IPCC) significantly expand and intensify its efforts to facilitate the attainment of world-wide consensus on scientific aspects of problems of climate change. Such consensus appears essential to the achievement of appropriate resolutions of these problems. In view of its neutrality, independence, international stature, and resources, the IPCC appears uniquely qualified, among organizations, to undertake such an endeavor.

1051. SACHS, The AGE OF SUSTAINABLE DeVELOPMENT (2015), supra note 71, at 172.

1052. Id. at 174

1053. SACHS, The AGE OF Sustainable DeVElOPMENT (2015), supra note 71, at 175.

1054. Id. 
On the issue of technological feasibility of measures to mitigate and facilitate adaptation to the effects of climate change, there are reasonable grounds for a general assessment that materials, products, and processes exist in the modern world to enable a concerted, steady-paced transition from the current non-renewable energy resources, to wind, solar, and other "green" technologies for the generation of all required electric power world-wide.

In respect to aid for nations in a state of extreme poverty, experience indicates that Official Development Assistance (ODA) can make a significant difference when it is operated on a professional basis for the real purpose of development, and is grounded in accurate diagnoses of the needs of recipient lowincome nations. ${ }^{1055}$ Mr. Jeffrey D. Sachs, Director of the UN Sustainable Development Solutions observes: "[ODA] comes at very low cost, less than 1 percent of the national income of the donor countries. If the rich world makes that effort, and if the funds are well used, ODA indeed can help to ensure that we are the generation that ends extreme poverty."1056

1055. Sachs, The Age OF Sustainable DeVelopment (2015), supra note 71, at 175. 1056. Id. 


\section{UN Secretary-General's 2019 Report on SDGs}

The "Sustainable Development Goals Report 2019" authored and

submitted by the Honorable Mr. António Guterres, the Secretary-General of the

United Nations since January 1, 2017, indicates that progress is being made in

some critical areas, and that some favorable trends are evident:

.... Extreme poverty has declined considerably, the under- 5 mortality rate fell by 49 per cent between 2000 and 2017, immunizations have saved millions of lives, and the vast majority of the world's population now has access to electricity. Countries are taking concrete actions to protect our planet: marine protected areas have doubled since 2010; countries are working concertedly to address illegal fishing; 186 parties have ratified the Paris Agreement on climate change, and almost all have communicated their first nationally determined contributions. About 50 countries have developed national policies to respond to the challenges of rapid urbanization, and 71 countries and the European Union now have more than 300 policies and instruments supporting sustainable consumption and production. And a wide range of other actors - international organizations, businesses, local authorities, the scientific community and civil society - have engaged with the SDGs in a manner that generates great hope for the coming decade. The United Nations, for its part, is working hard to reposition to the United Nations development system to be better equipped to meet the needs of governments...

Mr. Guterres conceded the following shortcomings in the results to date: It is abundantly clear that a much deeper, faster and more ambitious response is needed to unleash the social and economic transformation needed to achieve our 2030 goals. From our advances, we know what works. This report therefore highlights areas that can drive progress across all 17 SDGs: financing; resilience; sustainable and inclusive economies; more effective institutions; local action; better use of data; and harnessing science, technology and innovation with a greater focus on digital transformation. ${ }^{1058}$

1057. United Nations, The Sustainable Development Goals Report 2019. https://unstats.un.org/sdgs/report/2019/The-Sustainable-Development-Goals-Report2019.pdf

1058. Id. 


\section{Appointment of 17 SDG Advocates by UN Secretary-General}

The U.N. Secretary-General, Mr. Antonio Guterres, has appointed SDG Advocates to advance the Sustainable Development Goals (SDGs) and subsidiary targets of U.N. General Assembly Resolution A/RES/70/1. These 17 influential public figures have been tasked with "raising awareness, inspiring greater ambition, and pushing for faster action on the SDGs)." ${ }^{, 1059}$

The SDG Advocates appointed by the Secretary-General, and currently serving in office are as follows: ${ }^{\mathbf{1 0 6 0}}$

\section{Co-Chairs:}

1. Nana Addo Dankwa Akufo-Addo, President of Ghana,

2. Erna Solberg, Prime Minister of Norway,

Members:

3. Queen Mathilde of the Belgians,

4. Muhammadu Sanusi II, Emir of Kano (Nigeria),

5. Sheikha Moza bint Nasser, Founder, Education Above All Foundation (Qatar),

6. Richard Curtis, Screenwriter, Producer and Film Director (United Kingdom),

7. Hindou Oumarou Ibrahim, Activist, Environment and Indigenous Rights (Chad),

8. Jack Ma, Founder and Executive Chairman, Alibaba Group (China),

9. Graça Machel, Founder, Graça Machel Trust (Mozambique),

1059. U.N. PRESS RELEASE, May 9, 2019, https://www.un.org/press/en/2019/sga1872.doc.htm (last visited: Jul 13, 2019). 1060. Id. 
10. Dia Mirza, Actress and Film Producer, United Nations Environment Programme and Goodwill Ambassador for India,

11. Alaa Murabit, Founder, The Voice of Libyan Women (Canada),

12. Nadia Murad, Nobel Laureate, Chair and President, Nadia's Initiative, United Nations Office on Drugs and Crime, Goodwill Ambassador (Iraq),

13. Edward Ndopu, Founder, Global Strategies on Inclusive Education (South Africa),

14. Paul Polman, Chair, International Chamber of Commerce, Vice-Chair, Board of United Nations Global Compact (Netherlands),

15. Jeffrey D. Sachs, Director, Center for Sustainable Development, Columbia University (United States),

16. Marta Vieira da Silva, Footballer, Orlando Pride, UN-Women Goodwill Ambassador (Brazil),

17. Forest Whitaker, Founder and Chief Executive Officer, Whitaker Peace and Development Initiative, UNESCO Special Envoy for Peace and Reconciliation (United States).

The following excerpt is reproduced from a United Nations Press Release

dated May 9, 2019, presenting objectives that animated the actions of Secretary-

General Antonio Guterres in appointing SDG Advocates:

To build the momentum for transformative, inclusive development by 2030 , the Secretary-General's SDG Advocates will use their unique platforms and leadership to inspire cross-cutting mobilization of the global community. "We have the tools to answer the questions posed by climate change, environmental pressure, poverty and inequality. They lie in the great agreements of 2015-the 2030 Agenda for Sustainable Development and the Paris Agreement on climate change," the Secretary-General said. "But tools are no use if you don't use them," he emphasized. "So, today, and every day, my appeal is clear and simple," he added. "We need action, ambition and political will. More action, more ambition and more political will."1061

1061. U.N. PRESS RELEASE, May 9, 2019, https://www.un.org/press/en/2019/sga1872.doc.htm (last visited: Jul 13, 2019). 


\section{E. Serious Reported Deficiencies in Implementation of SDGs}

"Three years after the Sustainable Goals were announced and presented to the world, the report of implementation is not satisfactory." said former UN Secretary-General Mr. Ban Ki-moon, at the March 2019 Boao Forum, an event held annually in the Hainan Province of China, "We need global concerted action; then we have to work for common development in accordance with Sustainable Development Goals United Nations has presented to the world.",1062 A similar assessment was offered by Ms. Helen Clark, a former Prime Minister of New Zealand, at a meeting held in January 2019 at Madrid, hosted by the Government of Spain. ${ }^{\mathbf{1 0 6 3}}$ Ms. Clark, who headed the United Nations Development Program (UNDP) from 2009 to 2017, said that, because of delays in implementation, the Sustainable Development Goals (SDGs) [agenda] . . . "has gone under the radar."1064

Ms. Clark stated that the number of hungry people in the world had risen three years in a row after previous reductions, a fact that, she felt, was "undoubtedly related to climate change and displacement."1065 She noted that, under current estimates, 6 percent of the global population - or close to half a billion people - would still be living in extreme poverty by the year $2030 .^{\mathbf{1 0 6 6}}$

1062. Megan Rowling, Global Leadership Deficit Leaves Development Goals in Doldrums, REUTERS, Jan. 17, 2019, https://www.reuters.com/article/us-global-development- climatechange/globalleadership-deficit-leaves-development-goals-in-doldrums-idUSKCN1PB2UM

1063. Id. 1064. Id. 1065. Id. 1066. Id. 
Ms. Clark pointed to changes in the world's "political landscape" as another factor that has made the 2030 goals "more elusive." ${ }^{\text {1067 }}$ She stated that the unity of the international community that had allowed the SDGs and Paris Agreement on climate change to be adopted in 2015 had been "shattered" by these shifts. ${ }^{1068}$ She noted, further, that the political shifts had taken the pressure off of certain nations to act, including China and India, both of which were still continuing to invest in coal-fired power plants although they were signaling a shift away from dirty energy. ${ }^{1069}$

At the same event in Madrid, Mr. Jeffrey D. Sachs, who is currently one of the UN SDG Advocates appointed by the Secretary-General, expressed concern over the fact that "'nothing' had happened at the global level in the past three years." ${ }^{\mathbf{1 0 7 0}}$ Mr. Sachs, Director of the UN Sustainable Development Solutions Network (SDSN), assigned responsibility for lack of progress on the SDGs and the Paris Agreement to "a dearth of leadership, the unfairness of the global economic system, and the fact that there was essentially no plan for putting the 2015 agenda of General Assembly Resolution A/RES/70/1 into practice."1071 He suggested that the introduction of a worldwide "wealth tax" on billionaires could be a means of "getting education to every child on the planet." ${ }^{1072}$

\footnotetext{
1067. Megan Rowling, Global Leadership Deficit Leaves Development Goals in Doldrums, REUTERS, Jan. 17, 2019, supra note 1062, https://www.reuters.com/article/us-global-development-climatechange/ global-leadership-deficit-leaves-development-goals-in-doldrums-

1068. Id. idUSKCN1PB2UM

1069. Id.

1070. Id.

1071. Id.

1072. Id.
} 


\section{F. The Need for Executive Leadership in Implementation of SDGs}

The foregoing assessments, of Mr. Ban Ki-moon, former UN SecretaryGeneral, Ms. Helen Clark, a former Prime Minister of New Zealand, and Mr. Jeffrey D. Sachs, Director of the UN Sustainable Development Solutions Network (SDSN), seem to indicate, directly or by implication, that the primary impediment to the implementation of the 17 goals and 169 subsidiary tasks of UN General Assembly Resolution A/RES/70/1 is the absence of effective executive leadership to: (a) formulate and execute a collaborative global implementation plan; and (b) deal effectively with political, scientific, technical, financial, and other issues that can be expected to appear in the course of implementation. ${ }^{\mathbf{1 0 7 3}}$ The question arises, therefore, whether, executive leadership for an SDG Initiative can be sought in the person of the UN Secretary-General, who has been designated the Chief Administrative Officer of the entire UN Organization in Article 97 of the UN Charter, and who has been granted significant political powers under Articles 98 and 99 of the UN Charter. ${ }^{1074}$

In the material that follows, Resolution $\mathrm{A} / \mathrm{RES} / 70 / 1$ is scrutinized to ascertain whether an executive role, or its equivalent, for the Secretary-General has been specified in its provisions. ${ }^{\mathbf{1 0 7 5}}$

1073. Megan Rowling, Global Leadership Deficit Leaves Development Goals in Doldrums, REUTERS, Jan. 17, 2019, supra note 1062, https://www.reuters.com/article/us-global-development-climatechange/globalleadership-deficit-leaves-development-goals-in-doldrums-idUSKCN1PB2UM

1074. U.N. CHARTER articles 97, 98, 99.

1075. U.N. General Assembly Resolution A/RES/70/1, supra note 17. 
A careful examination of the provisions of A/RES/70/1 reveals the

following references to responsibilities of the UN Secretary-General:

- Paragraph 6 states the following: "The Goals and targets are the result of over two years of intensive public consultation and engagement with civil society and other stakeholders around the world, which paid particular attention to the voices of the poorest and most vulnerable. This consultation included valuable work done by the Open Working Group of the General Assembly on Sustainable Development Goals and by the United Nations, whose Secretary-General provided a synthesis report in December 2014."1076

- Paragraph 70 states the following: "The United Nations inter-agency task team on science, technology and innovation for the Sustainable Development Goals will promote coordination, coherence and cooperation within the United Nations system on science, technology and innovation-related matters, enhancing synergy and efficiency, in particular to enhance capacity-building initiatives. The task team will draw on existing resources and will work with 10 representatives from civil society, the private sector and the scientific community to prepare the meetings of the multi-stakeholder forum on science, technology and innovation for the Sustainable Development Goals, as well as in the development and operationalization of the online platform, including preparing proposals for the modalities for the forum and the online platform. The 10 representatives will be appointed by the Secretary-General, for periods of two years. The task team will be open to the participation of all United Nations agencies, funds and programmes and the functional commissions of the Economic and Social Council . . . ."

- Paragraph 83 states the following: "Follow-up and review at the high-level political forum will be informed by an annual progress report on the Sustainable Development Goals to be prepared by the Secretary-General in cooperation with the United Nations system, based on the A/RES/70/1 Transforming our world: the 2030 Agenda for Sustainable Development 34/35 global indicator framework and data produced by national statistical systems and information collected at the regional level. . . .".1078

1076. U.N. General Assembly Resolution A/RES/70/1, supra note 17, at II 6 .

1077. U.N. General Assembly Resolution A/RES/70/1, supra note 17, at II 70.

1078. U.N. General Assembly Resolution A/RES/70/1, supra note 17, at II 83. 
- Paragraph 90 states the following: "We request the SecretaryGeneral, in consultation with Member States, to prepare a report, for consideration at the seventieth session of the General Assembly in preparation for the 2016 meeting of the high-level political forum, which outlines critical milestones towards coherent, efficient and inclusive follow-up and review at the global level. , ,.,1079

As can readily be seen from the provisions of General Assembly Resolution A/RES/70/1 reproduced above, the role envisaged for the UN Secretary-General in the attainment of the 17 goals and 169 targets of A/RES/70/1 appears largely to have been as a high-level administrative officer. However, from the language of $\mathrm{A} / \mathrm{RES} / 70 / 1$, it does not appear that the Secretary-General was envisaged as an executive leader in respect to the activities to be carried out in the implementation of Resolution A/RES/70/1.

The question arises, therefore, as to whether the UN Secretary-General can so interpret his powers under principles of the UN Charter as to function as an executive leader, rather than purely as a high-level administrative officer, in the challenging situations and exigencies presented by General Assembly Resolution A/RES/70/1.

\section{G. The UN Secretary-General as Executive Leader}

Section G of Part IV presents suggestions on the nature of the leadership and supporting organization that will be necessary to facilitate progress in the SDG Initiative.

1079. U.N. General Assembly Resolution A/RES/70/1, supra note 17, at II 90. 
(1) The Essential Role of the United Nations as the Overall Coordinating Authority of the Worldwide Sustainable Development Initiative

(a) General Lack of Consensus on Issues of Climate Change

As indicated in Section C(1) of Part IV of this study, there are significant differences in viewpoint between the Intergovernmental Panel on Climate Change (IPCC) and certain members of the scientific community and others, on issues of global climate change and its relationship to anthropogenic activities. ${ }^{\mathbf{1 0 8 0}}$

The IPCC has stated: "Warming of the climate system is unequivocal, and since the 1950s, many of the observed changes are unprecedented over decades to millennia."1081 Further, “. . . their effects (the effects of anthropogenic greenhouse gas emissions) . . . have been detected throughout the climate system and are extremely likely to have been the dominant cause of the observed warming since the mid-20th century.",1082

In direct contrast to the IPCC's assertions, Professor Ian Plimer, Emeritus Professor of Earth Sciences at the University of Melbourne, and Professor of Mining Geology at the University of Adelaide, Australia, has observed that only one out of 85,000 molecules in the atmosphere is carbon dioxide $\left(\mathrm{CO}_{2}\right)$ of human origin; whereas, in comparison, $32 \mathrm{CO}_{2}$ molecules out of every 85,000 molecules in the atmosphere, are of natural origin. ${ }^{\mathbf{1 0 8 3}}$ Based on these observations, Professor Plimer has expressed doubt in regard to the hypothesis that human-

1080 See supra text accompanying notes 173-177.

1081. See supra text accompanying note 173.

1082. See supra text accompanying note 176.

1083. See supra text accompanying notes 623-625.. 
generated $\mathrm{CO}_{2}$ "drives hugely complex climate change systems. ${ }^{\mathbf{1 0 8 4}}$

In consonance with Professor Plimer's views, Dr. Richard S. Lindzen, Atmospheric Physicist, and former Professor of Meteorology at the Massachusetts Institute of Technology (MIT), made the following emphatic pronouncement: "What we have seen is that climate is probably insensitive to increases in greenhouse gases, and [that] there is little reason to suppose that a warmer world will be notably characterised by storminess and extremes though both are part of normal weather variability."

The material presented indicates significant divergence of view between the IPCC and respected members of the scientific community and others, on issues of global climate change. The question arises, therefore, as to the need for, and character of, services to be provided by an individual, group, or organizational entity, to move the parties toward a consensual position.

(b) A Necessary Role for a Principal Organ of the U.N. It is a real possibility that issues arising from shortfalls in the realization of one or more of the 17 goals and 169 targets of United Nations General Assembly Resolution 70/1 (A/RES/70/1) could lead to major breaches of international peace and security. Such shortfalls could include severe shortages of basic human necessities, the prevalence and growth of fundamental societal inequalities (within and between nations), and environmental degradation leading to extreme events

1084. Id.

1085. See supra text accompanying note 588 
such as climate change and loss of habitable and cultivable land. In view of the global scope and seriousness of these adverse possibilities, it appears that one of the principal organs of the United Nations should logically be considered for a role of executive and leader of an international initiative to prevent descent into such situations.

A notable feature in the development of the jurisprudence of the United Nations has been the practice of interpreting the Charter as a Constitution, and not simply as a treaty. This practice is reflected in the following pronouncement by the distinguished second Secretary-General, Dag Hammarskjöld, in the context of the Suez Crisis of 1956:

The principles of the Charter are by far, greater than the Organization in which they are embodied, and the aims which they are to safeguard are holier than the policies of any single nation or people. As a servant of the Organization, the SecretaryGeneral has the duty to maintain his usefulness by avoiding public stands on conflicts between Member nations unless and until such action might help to resolve the conflict. . . .

He must also be a servant of the principles of the Charter, and its aims must ultimately determine what for him is right and wrong. . . . He should also be able to assume that those organs which are charged with the task of upholding the Charter will be in a position to fulfill their task. ${ }^{\mathbf{1 0 8 6}}$

Article 1(1) of the Charter states that it is one of the purposes of the United Nations: “. . . to bring about by peaceful means, and in conformity with the principles of justice and international law, adjustment or settlement of international disputes or situations which might lead to a breach of the peace."1087

1086. BRIAN URQUHART, HAMMARSKJÖLD 174 (1994).

1087. U.N. Charter, Article 1(1).. 
The principle stated in Article 1(1) is amplified and clarified in Article 33, which provides: "The parties to any dispute, the continuance of which is likely to endanger the maintenance of international peace and security, shall, first of all, seek a solution by negotiation, enquiry, mediation, conciliation, arbitration, judicial settlement, resort to regional agencies or arrangements, or other peaceful means of their own choice."

(c) The Evolution of the United Nations as a Dynamic Instrument for Reconciliation and for Joint Governmental Executive Action

In the introduction to his 1961 report on the work of the United Nations,

Secretary-General Dag Hammarskjöld spoke of the UN Organization as:

a dynamic instrument of Governments through which they, jointly and for the same purpose, should seek such reconciliation but through which they should also try to develop forms of executive action, undertaken on behalf of all Members, and aiming at forestalling conflicts and resolving them, once they have arisen, by appropriate diplomatic or political means, in a spirit of objectivity and in implementation of the principles and purposes of the Charter . . The first concept can refer to history and to the traditions of national policies of the past. The second can point to the needs of the present and of the future in a world of ever-closer international interdependence. . . . The first one is firmly anchored in the time-honoured philosophy of sovereign national states in armed competition . . . The second one envisages possibilities of intergovernmental action overriding such a philosophy, and opens the road towards more developed and increasingly effective forms of constructive international cooperation. ${ }^{\mathbf{1 0 8 9}}$

1088. U.N. Charter, Article 33.

1089. Dag Hammarskjöld, The Choice (Introduction to the Secretary-General's Annual Report to the U.N., 1961), in SERVANT OF PEACE: A SELECTION OF THE SPEECHES AND STATEMENTS OF DAG HAMMARSKŐLD, 354-355 (Wilder Foote ed. 1962). 
The evolution of the conception of the dynamic nature of the United Nations has involved the recognition of the General Assembly and the UN Councils (Security Council, Economic and Social Council, Trusteeship Council) as more than diplomatic conferences, and as possessing some of the characteristics of parliamentary organs. ${ }^{1090}$ It has also envisioned expansion of the political role of the Secretary-General, both in respect of his independent initiatives and in respect of his executive role in carrying out assigned tasks. ${ }^{1091}$

The Charter places upon the Security Council the primary responsibility for the maintenance of international peace and security. ${ }^{1092}$ The terms and the tenor of the Charter make it clear that its framers intended the Security Council to be the executive organ of the U.N. Organization. ${ }^{1093}$ However, events proved the need for an alternative assignment of executive responsibility. On occasions when the Security Council became deadlocked, the principal responsibility for political problems shifted from the Security Council to the General Assembly. ${ }^{1094}$ The resulting adjustment in the balance of power between two of the principal organs of the United Nations did not, however, represent a final resolution of issues of international peace and security, since the General Assembly lacked certain critically important powers of the Security Council - in particular, the

1090. M. G. Kaladharan Nayar, Dag Hammarskjöld and U Thant: The Evolution of their Office, CASE W. Res. J. INT’L L., VOL. 7, No. 1. 60 (WINTER 1974).

1091. Id.

1092. U.N. CHARTER Article 24.

1093. M. G. Kaladharan Nayar, Dag Hammarskjöld and U Thant: The Evolution of their Office, CASE W. RES. J. INT'L L., VOL. 7, No. 1 (WINTER 1974), supra note 1090, at 61.

1094. M. G. Kaladharan Nayar, Dag Hammarskjöld and U Thant: The Evolution of their Office, CASE W. RES. J. INT'L L., VOL. 7, NO. 1 (WINTER 1974), supra note 1090, at 61. 
power to make decisions binding on member states. ${ }^{1095}$ Further, because of its size, complexity, the variety of interests represented in its constituent body, and its operating procedures, the General Assembly proved incapable of exercising executive functions in an effective manner. ${ }^{1096}$ This development, in turn, resulted in a further shift in responsibility for executive functions, from the General Assembly to the Secretary-General. ${ }^{1097}$

A category of events that influenced the development of the SecretaryGeneral's political role was the emergence, in the post-colonial period, of a large number of newly-constituted States in Asia and Africa, and the resultant expansion of the membership of the United Nations. The result was a shift in the balance of forces within the U.N. Organization, when the focal points of crises moved from the Security Council to the General Assembly. ${ }^{1098}$ The overriding concern of the newly formed states to avoid a reinstatement of colonial dominion, led them to look to the U.N. Secretary-General as an authoritative representative within the Organization who could be entrusted with the task of organizing and dispensing aid from the United Nations. ${ }^{1099}$

1095. M. G. Kaladharan Nayar, Dag Hammarskjöld and U Thant: The Evolution of their Office, CASE W. ReS. J. INT’L L., Vol. 7, No. 1 (WINTER 1974), supra note 1090, at 61.

1096. Id.

1097. Id.

1098. Id.

1099. M. G. Kaladharan Nayar, Dag Hammarskjöld and U Thant: The Evolution of their Office, CASE W. ReS. J. INT’L L., VOL. 7, No. 1 (WINTER 1974), supra note 1090, at 61-62. 
(d) The Secretariat of the United Nations \& the Authority of the Secretary-General

In Article 7 of the U.N. Charter, the Secretariat has been designated as one of the "principal organs" of the United Nations. ${ }^{\mathbf{1 1 0 0}}$ The Secretariat has, therefore, been endowed by the Charter with status coequal to that of the General Assembly, the Security Council, the Economic and Social Council, the Trusteeship Council, and the International Court of Justice. ${ }^{1101}$ The significance of the investiture of particular U.N. organizational entities with the status of "principal organs," is that it is the principal organs that are primarily responsible for the attainment of the objectives of the U.N., and for the upholding of the principles of the Charter. ${ }^{\mathbf{1 1 0 2}}$ Accordingly, the Secretariat appears as one of the organizational units bearing responsibility for the constitutional conduct of the Member States of the U.N.

Article 97 of the Charter states that: "The Secretariat shall comprise a Secretary-General and such staff as the Organization may require.”,1103 Further, Article 97 provides: "The Secretary-General shall be appointed by the General Assembly upon the recommendation of the Security Council. He shall be the chief administrative officer of the Organization." $" 1104$ The use of the word, "Secretariat" in Article 97 in conjunction with the phrase, "such staff as the Organization may require," and the stipulation that the Secretary-General is

1100. U.N. Charter, Article 7.

1101. U.N. Charter, Article 7.

1102. M. G. Kaladharan Nayar, Dag Hammarskjöld and U Thant: The Evolution of their Office, CASE W. RES. J. INT’L L., VOL. 7, NO. 1 (WINTER 1974), ), supra note 1090, at 37.

1103. U.N. Charter, Article 97.

1104. U.N. Charter, Article 97. 
the chief administrative officer of the Organization, suggest that the Secretariat was conceived of as an integrated group, led by the Secretary-General. ${ }^{\mathbf{1 1 0 5}}$

In the material that follows, the history of the evolution of the office of U.N. Secretary-General will be examined for a comprehensive understanding of its current complex and multi-faceted constitution. The question will be considered as to whether the office of Secretary-General can expand, grow, and develop to meet the immense and unprecedented challenges raised by the implementation of the 17 goals and 169 targets of the Sustainable Development Initiative that was launched by General Assembly Resolution A/RES/70/1. ${ }^{1106}$

\section{(e) The Complex and Multi-Dimensioned Office of Secretary-General of the United Nations}

The Secretary-General of the United Nations is appointed by the General Assembly upon recommendation of the Security Council, ${ }^{\mathbf{1 1 0 7}}$ and the members of the staff of the Secretariat are appointed by the Secretary-General under regulations established by the General Assembly, ${ }^{\mathbf{1 1 0 8}}$ Regulation 1.2(c) of the Staff Regulations of the United Nations provides that "[s]taff members are subject to the authority of the Secretary-General and to assignment by him or her to any of the activities or offices of the United Nations."1109

1105. M. G. Kaladharan Nayar, Dag Hammarskjöld and U Thant: The Evolution of their Office, CASE W. RES. J. INT’L L., VOL. 7, No. 1 (WINTER 1974), supra note 1090, at 37.

1106. U.N. General Assembly Resolution A/RES/70/1, supra note 1.

1107. U.N. Charter, Article 97..

1108. U.N. Charter, Article 101(1).

1109. Staff Regulations of the United Nations, Regulation 1.2(c). 
The Preparatory Commission of the United Nations held similar views in regard to the position and authority of the Secretary-General within the overall United Nations Organization, as indicated by the following statement from the report of the Commission, issued in 1945:

[T]he Secretary-General more than anyone else, will stand for the United Nations as a whole. In the eyes of the world, no less than in the eyes of his own staff, he must embody the principles and ideals of the Charter to which the Organization seeks to give effect. ${ }^{\mathbf{1 1 0}}$

Further, the Preparatory Commission provided: "The Secretary-General is the head of the Secretariat. He appoints all staff under regulations established by the General Assembly (Article 101, paragraphs1 and 3), and assigns appropriate staff to the various organs of the United Nations (Article 101, paragraph2)."1111 The Commission stated: "[The Secretary-General] alone is responsible to the other principal organs for the Secretariat's work; . . ."1112

In light of the foregoing pronouncements in the Staff Regulations and the Preparatory Commission, Dr. M. G. Kaladharan Nayar, Attorney at Law, and eminent scholar of Human Rights made the insightful observation that it is

1110. Report of the Preparatory Commission of the United Nations, PC/EX/113/Rev. 1, December 12, 1945, at 75, para. 17, https://digitallibrary.un.org/record/703121/files/PC_EX_113_Rev.1-EN.pdf (last visited Apr. 6, 2019).

1111. Report of the Preparatory Commission of the United Nations, PC/EX/113/Rev. 1, December 12, 1945, supra note 816, at 75, para. 15. https://digitallibrary.un.org/record/703121/files/PC_EX_113_Rev.1-EN.pdf (last visited Apr. 6, 2019).

1112. Report of the Preparatory Commission of the United Nations, PC/EX/113/Rev. 1, December 12, 1945, supra note 816, at 75, para. 15. https://digitallibrary.un.org/record/703121/files/PC_EX_113_Rev.1-EN.pdf (last visited Apr. 6, 2019). 
"appropriate to regard the Secretary-General as embodying in his person, the whole of the Secretariat."1113 Dr. Nayar concluded that the Secretary-General has, therefore, "been referred to as a principal organ in the meaning of Article 7 of the Charter, (although Article 7 refers to the Secretariat, and not to the SecretaryGeneral)."1114 In this context, it is noteworthy that Dag Hammarskjöld, the distinguished second U.N. Secretary-General (1953-1961), described his Office as a "one-man executive."

In regard to the question of overall authority within the U.N. Organization, the Preparatory Commission made the following pronouncement:

All officials of the United Nations must recognize the exclusive authority of the Secretary-General and submit themselves to rules of discipline such as are normally enforced in national civil services. $^{1116}$

Article 97 of the U.N. Charter designates the Secretary-General "the chief administrative officer" not merely of the Secretariat but of the United Nations Organization as a whole. ${ }^{1117}$ In the context of this designation, Dag Hammarsk jōld observed that "[the Secretary-General] is the only elected officer in principle

1113. Nayar, Dag Hammarskjöld and U Thant: The Evolution of their Office, CASE W. RES. J. INT’L L., VOL. 7, No. 1 (WINTER 1974), supra note 1086, at 42.

1114. Id.

1115. Dag Hammarskjöld, The Development of a Constitutional Framework for International Cooperation (Address at Chicago University Law School, May 1, 1960), in SERVANT OF PEACE: A SELECTION OF THE SPEECHES AND STATEMENTS OF DAG HAMMARSKÖLD, (Wilder Foote ed. 1962), supra note 1085, at 255.

1116. Report of the Preparatory Commission of the United Nations, PC/EX/113/Rev. 1, December 12, 1945, supra note 809 , at 74 , para. 5 , https://digitallibrary.un.org/record/703121/files/PC_EX_113_Rev.1-EN.pdf (last visited Apr. 6, 2019).

1117. U.N. Charter, Article 97. 
representing all members."1118 In Hammarskjöld's view, "the rules of election aim at ensuring that the Secretary-General, as one of the main organs of the United Nations, "shall have the opportunity of functioning as the spokesman of the Organization in its capacity as an independent opinion factor."1119

Articles 98 and 99 of the U.N. Charter give the Secretary-General a role with powers and responsibilities extending far beyond those of the traditional non-political civil servant. The attributes of the office were expounded upon by Dag Hammarskjöld as follows:

In Article 98 it is provided. . . that the Secretary-General 'shall 'perform such other functions as are entrusted to him by these organs' [(the General Assembly and the Security Council)]. This latter provision . . . entitles the General Assembly and the Security Council to entrust the Secretary-General with tasks involving the execution of political decisions, even when this would bring himand with him the Secretariat and its members - into the arena of possible political conflict. . . . [In] doing so, the General Assembly and the Security Council are in no way in conflict with the spirit of the Charter..., since the Charter itself gives to the SecretaryGeneral an explicit political role. ${ }^{\mathbf{1 1 2 0}}$

1118. Dag Hammarskjöld, The Development of a Constitutional Framework for

International Cooperation (Address at Chicago University Law School, May 1, 1960), In SERVANT OF PEACE: A SELECTION OF THE SPEECHES AND STATEMENTS OF DAG HAMMARSKÖLD, (Wilder Foote ed. 1962), supra note 1085, at 255.

1119. Nayar, Dag Hammarskjöld and U Thant: The Evolution of their Office, CASE W. RES. J. INT'L L., VOL. 7, No. 1 (WINTER 1974), supra note 1086, at 42. (citing Hammarskjöld, Dag, Do We Need the United nations? - An Affirmative Answer (Copenhagen speech, May 2, 1959), in SERVANT oF PEACE: A SELECTION OF THE SPEECHES AND STATEMENTS OF DAG HAMMARSKÖLD, (Wilder Foote ed. 1962), supra note 1085 , at 208 .

Hammarskjōld asserted: "The Secretary-General is elected by the General Assembly, but on the recommendation of the Security Council, and this recommendation requires unanimity among the five permanent Council members. The purpose of this arrangement is to ensure that the Secretary-General shall, as far as possible, be placed outside or lifted above conflicts which may split the Assembly or the Council.

1120. Dag Hammarskjöld, The International Civil Servant in Law and in Fact, Lecture Delivered to Congregation at Oxford University, May 30, 1961, in SERVANT OF PEACE: A SELEC-TION OF THE SPEECHES AND STATEMENTS OF DAG HAMMARSKŐLD, (Wilder Foote ed. 1962), supra note 1085, at 335. 


\section{(f) The Political Role of the Secretary-General}

Articles 98 and 99 in the U.N. Charter state the political responsibilities of the Secretary-General. The presence of these two articles in the Charter represents a radical departure of the U.N. Secretary-Generalship from the Secretary-Generalship of the League of Nations. ${ }^{1121}$ Article 98 states that the Secretary-General may be entrusted with responsibilities involving the exercise of substantial discretion and political judgment, the range of such responsibilities being limited only by the functions and powers of the General Assembly and the Councils. ${ }^{\mathbf{1 1 2 2}}$ In effect, the degree to which responsibilities are entrusted to the Secretary-General is a function of the willingness of governments to allow decisions to pass from their control, the confidence inspired by the particular incumbent of the Secretary-General's Office, and the advantages that governments perceive in the arrangement. ${ }^{\mathbf{1 1 2 3}}$

The assignment of responsibilities to the Secretary-General necessarily requires permitting him to exercise a degree of discretion in the execution of the functions concerned. Situations involving peace and security could require the exercise of political judgment by the Secretary-General, particularly where directives provided by resolutions of the Security Council or the General Assembly do not cover unusual aspects of specific situations. In the Congo events, which occurred during Dag Hammarskjöld's tenure as Secretary

1121. Nayar, Dag Hammarskjöld and U Thant: The Evolution of their Office, CASE W. RES. J. INT'L L., VOL. 7, No. 1 (WINTER 1974), supra note 1086, at 43.

1122. U.N. Charter, Article 98.

1123. Nayar, Dag Hammarskjöld and U Thant: The Evolution of their Office, CASE W. RES. J. INT'L L., VOL. 7, No. 1 (WINTER 1974), supra note 1086, at 44. 
General, there was disagreement over "the Secretary-General's interpretation of his powers with respect to the introduction of United Nations forces into Katanga, the role of these forces in the civil war, and the extent to which support might be given to one or other claimant to legitimate authority."1124

Hammarskjöld explained that, in the prevailing circumstances, "he was faced with the alternatives of refusing to proceed with his mission, which would have meant chaos, or of undertaking to carry out his assignment on the basis of his international responsibility, even though he had to deal with controversial issues." 1125 In following the latter course, he sought guidance in the principles of the Charter, prevailing legal doctrine accepted by states generally, and the opinions of U.N. member states as articulated by their permanent representatives. ${ }^{1126}$

(g) The Powers Granted to the Secretary-General under Charter Article 99 Of the provisions of the Charter, it is Article 99 that gives the SecretaryGeneral explicit political power and responsibility in his own right. Article 99 states: "The Secretary-General may bring to the attention of the Security-Council any matter which in his opinion may threaten the maintenance of international peace and security."1127

1124. Nayar, Dag Hammarskjöld and U Thant: The Evolution of their Office, CASE W. RES. J. INT'L L., VOL. 7, No. 1 (WINTER 1974), supra note 1086, at 45.

1125. Id.

1126. Id.

1127. U.N. Charter, Article 99. 
The critically important political role of the Secretary-General under

Article 99 of the U.N. Charter was explicitly recognized by the Preparatory

Commission, as indicated by the following excerpt from the Commission's

Report of 1945:

The Secretary-General may have an important role to play as a mediator and as an informal adviser of many Governments, and will undoubtedly be called upon from time to time, in the exercise of his administrative duties, to take decisions which may justly be called political. Under Article 99 of the Charter, moreover, he has been given a quite special right which goes beyond any power previously accorded to the head of an international organization viz: to bring to the attention of the Security Council any matter (not merely any dispute or situation) which, in his opinion, may threaten the maintenance of international peace and security. It is impossible to foresee how this Article will be applied; but the responsibility it confers upon the Secretary-General will require the exercise of the highest qualities of political judgment, tact and integrity. ${ }^{\mathbf{1 1 2 8}}$

The foregoing statement of the Preparatory Commission was conveyed by the General Assembly in Resolution 13(I), on February 13, 1946, to the Secretary-General, for the latter's guidance. ${ }^{\mathbf{1 1 2 9}}$ Later, in a statement at the 1,329th meeting of the Security Council, on December 2, 1966, the President of the Council stated that its members "fully respect the [Secretary-General's] position and his action in bringing basic issues confronting the Organization . . . . to their notice."1130

1128. Report of the Preparatory Commission of the United Nations, PC/EX/113/Rev. 1, December 12 , 1945, supra note 809 , at 75 , para. 16 , https://digitallibrary.un.org/record/703121/files/PC_EX_113_Rev.1-EN.pdf (last visited Apr. 11, 2019).

1129. U.N. General Assembly Resolution 13(I), February 13, 1946.

1130. U.N. SCOR, 1,329th meeting, December 2, 1966, at 1. 
The Secretary-General's power to act under Article 99 of the U.N. Charter parallels that of member-states of the United Nations under Article 35, and the power of the General Assembly to act under Article 11(3). ${ }^{\mathbf{1 1 3 1}}$ An important distinction between the foregoing grants of authority is, however, in the fact that the Secretary-General's right to act under Article 99 can be triggered by "any matter," and not only by "any dispute, or any situation" as is required for member states under Article 35, and "situations" as required for the General Assembly under Article 11(3). ${ }^{\mathbf{1 1 3 2}}$ Thus, the Secretary-General's power to act under Article 99 must be considered to be of broader scope than the power of member states under Article 35, and that of the General Assembly under Article 11(3) of the U.N. Charter. ${ }^{1133}$

A significant feature of Article 99 is that it enables the Secretary-General to set the U.N.'s peacekeeping machinery in motion based solely on his individual assessment that a particular situation involves threats to peace and security, justifying such action. Perceptive observers have surmised that this specific structure of Article 99 was accepted at the U.N.'s primary nascent event, the Dumbarton Oaks Conference of 1944, because of a prevailing sense among the delegates at the Conference that the functioning of the system of the League of Nations had been severely hampered by the operation of its rule that only a member state could bring an alleged "threat to the peace" to the attention of the

1131. U.N. Charter, Article 11(3); U.N. Charter, Article 35; U.N. Charter, Article 99. 1132. U.N. Charter, Article 11(3); U.N. Charter, Article 35; U.N. Charter, Article 99. 1133. Id. 
League's Council. ${ }^{1134}$ Further, Article 99 provides that the Secretary-General may bring to the attention of the Security Council, any matter which, in his opinion, may threaten the maintenance of international peace and security. ${ }^{1135}$

Thus, the Secretary-General has double discretion. First, it is for him to decide whether, in his opinion, the matter would be eligible to be put on the agenda of the Council. Second, even if he comes to the conclusion that this is the case, he need not necessarily submit the matter to the Council. He may do so, but Article 99 makes it clear that there is no affirmative duty on him to go this far. It is still for him to decide whether he will formally invoke that Article, or take other or even no action. ${ }^{1136}$

The question as to whether the exercise of the Secretary-General's power to act under Article 99 should be made obligatory or optional was considered at the San Francisco Conference, and it was decided that the right "should be exercised at the discretion of the Secretary-General and should not be imposed upon him as a duty."1137 On the issue of whether the application of Article 99 should extend to the General Assembly in addition to the Security Council, it was argued at the San Francisco Conference that such an extension would violate the principle of the primary responsibility of the Security Council for the maintenance

1134. Nayar, Dag Hammarskjöld and U Thant: The Evolution of their Office, CASE W. RES. J. INT'L L., VOL. 7, No. 1 (WINTER 1974), supra note 1086, at 46 (citing R. RUSSELl, A History OF THE UNITED NATIONS CHARTER at 432)..

1135. U.N. Charter, Article 99.

1136. Nayar, Dag Hammarskjöld and U Thant: The Evolution of their Office, CASE W. RES. J. INT'L L., VOL. 7, No. 1 (WINTER 1974), supra note 1086, at 47.

1137. Nayar, Dag Hammarskjöld and U Thant: The Evolution of their Office, CASE W. RES. J. INT'L L., VOL. 7, No. 1 (WINTER 1974), supra note 1086, at 47 (7 U.N.C.I.O. Docs. 392. C $f$. GOOdRICH, HAMBro \& SimONS, CHARTER OF THE UNITED NATIONS at 589). 
of peace and security as stated in Article 24. ${ }^{1138}$

Although the Secretary-General's power to act under Article 99 is limited to reports to the Security Council, on matters threatening international peace and security, the rules of procedure of the General Assembly and the other U.N. Councils empower the Secretary-General to bring matters to their attention as well. ${ }^{1139}$ Further, Article 98's provision for an annual report by the SecretaryGeneral to the General Assembly furnishes the Secretary-General with another significant means of bringing to the attention of the General Assembly matters threatening international peace and security. ${ }^{\mathbf{1 1 0}}$

Lauterpacht has indicated the "considerable potentialities" inherent in Article 99 for bringing to the attention of the Security Council, violations of human rights so grave that they threaten the maintenance of international peace and security. ${ }^{1141}$ In responding to the apparently limiting effect on Article 99, of Article 2's clause of "domestic jurisdiction," he articulated the following reasoned pronouncement:

The clause of domestic jurisdiction of Article 2, paragraph 7, presents no impediment in the way of the exercise of this particular function of the Secretary-General. The matters referred to in Article 99 are not, by definition, essentially within the domestic jurisdiction of any state. ${ }^{\mathbf{1 1 4 2}}$

1138. Nayar, Dag Hammarskjöld and U Thant: The Evolution of their Office,

CASE W. RES. J. INT'L L., VOL. 7, No. 1 (WINTER 1974), supra note 1086, at 47

(7 U.N.C.I.O. Docs. 392. Cf. GoOdrich, HAMBro \& Simons, ChARTER OF THE UNITED NATIONS at 589; S. Schwebel, The Origins and Development of Article 99 of the Charter, 28 THE BRITISH YEARBOOK OF IINTERNATIONAL LAW 375 (1951).

1139. G.A. Rule 13; T.C. Rule 9; ECOSOC Rule 10.

1140. U.N. Charter, Article 98.

1141. LAUTERPACHT, supra note 662, at 187.

1142. Id. 
The Provisional Rules of Procedure of the Security Council require that the President of the Council must call a meeting of the body "if the SecretaryGeneral brings to the attention of the Security Council any matter under Article 99." ${ }^{1143}$ However, the Provisional Rules of Procedure of the Security Council require also that the Council retain mastery of its agenda, with the Secretary-General permitted only to place matters on the Council's provisional agenda, and argue for their adoption into the Council's working agenda. ${ }^{1144}$

Since the Secretary-General's right to place an issue before the Security Council derives from an explicit provision of Article 99 of the U.N. Charter, it seems extremely unlikely that the Council would refuse to take up any matter so presented. For instance, if the Secretary-General were to invoke his powers under Article 99 to request placement before the Security Council, a report detailing the imminent likelihood of a catastrophic event related to factors of global climate change, that threatens the maintenance of international peace and security, it is highly unlikely that the Council would refuse the request.

In the context of the Laotian crisis of 1960, Hammarskjöld explained the distinction between an initiative by the Secretary-General under Article 99, and a request that he be allowed to make a statement to the Security Council:

... I have based my action on a practice which has developed over the years in the Security Council. According to this practice, the Secretary-General, when he requests it, is granted the floor in the Council in order to make such statements on

1143. Security Council, Provisional Rules of Procedure, Doc. S/96 Rev. 7, Rule 3.

1144. Security Council, Provisional Rules of Procedure, Doc. S/96 Rev. 7. Rules 9, 6,22. 
subjects within the range of the responsibility of the Council as he considers called for under the terms of his own responsibilities. $^{1145}$ Just as the Secretary-General can ask for, and is granted the floor in the Council, I feel that he is entitled to request an opportunity to address the Council publicly on a matter which he considers necessary personally to put before the Council. In doing so within the framework to which I have just referred, the Secretary-General does not introduce formally on the agenda of the Council anything beyond his own wish to report to the Council. Naturally, the Council retains the same rights in relation to such initiative of the Secretary-General as it has regarding any request of his to address the Council. ${ }^{\mathbf{1 1 4 6}}$

What I said should be enough to clarify the constitutional situation when, in this case, I have asked for an opportunity to report to the Council. It should, thus, be clear that the request is not based on the explicit rights granted to the Secretary-General under Article 99 of the Charter. If it had been so based, the Council under rule 3 of the provisional rules of procedure, would not have been free to refuse the Secretary-General to address it - as it is now free to do - and it would have meant the inscription by the Secretary-General of a substantive issue on the agenda. In this latter respect it would necessarily also have involved a judgment as to facts for which, in the present situation, I have not a sufficient basis. ${ }^{1147}$

It has been generally recognized that the Secretary-General's right, under

Article 99 of the Charter, to place before the Security Council, matters which, in his opinion, could threaten international peace and security, carries with it, by implication, the right to make preliminary inquiries to ascertain whether he should proceed in this manner. ${ }^{1148}$ Thus Article 99, by necessary implication, grants to

1145. Rule 22 of the Provisional Rules of Procedure of the Security Council (Doc. S/96/Rev. 7).

1146. 14 U.N. SCOR, 847th meeting, II 11 (U.N. Doc. S/PV. 847, Sep. 7, 1959).

1147. 14 U.N. SCOR, 847th meeting, II 12 (U.N. Doc. S/PV. 847, Sep. 7, 1959), at 2-3.

1148. Nayar, Dag Hammarskjöld and U Thant: The Evolution of their Office, CASE W. ReS. J. INT'L L., Vol. 7, No. 1 (WINTER 1974), supra note 1086, at 50. 
the Secretary-General investigatory and exploratory authority, to be exercised in accordance with his judgment of the dynamics of particular situations that may arise. $^{1149}$

\section{(1) "Good Offices" of the Secretary-General}

The term known generally as the Secretary-General's "good offices" refers, in substance, to the appropriate psychological assistance that a SecretaryGeneral might offer to parties in conflict, if a spur should be needed to commence negotiations. ${ }^{1150}$ "Arising from 'the philosophy of the Charter, as reflected in Article 99, 'this notion of good offices gives the Secretary-General wide political and diplomatic possibilities of action of a less public nature.",1151

An increase in the incidence of use of the practice of "good offices" was taken note of by Hammarskjöld in his introduction to the 1959 Annual Report on the work of the U.N. Organization ${ }^{\mathbf{1 1 5 2}}$ In his presentation on the occasion, Hammarskjöld specifically referred to the growing incidence of cases in which the Secretary-General sent personal representatives to assist Governments in their efforts to find resolutions of difficult situations, thereby further developing the stature and viability of actions of a "good offices" nature. ${ }^{1153}$ These actions were

1149. Id.

1150. Nayar, Dag Hammarskjöld and U Thant: The Evolution of their Office, CASE W. RES. J. INT'L L., VOL. 7, NO. 1 (WINTER 1974), supra note 1086, at 52.

1151. Id. (Cf. Dictated versions of extemporaneous remarks by Secretary-General Hammarskjöld, at an official luncheon in Mexico City, April 8, 1959, quoted in Lash, Hammarskjöld's Conception of his Office, 16 INT'L ORGANIZATION 550 (1962-63)).

1152. 14 U.N. GAOR, Supp. No. 1A (A /4132/Add. 1).

1153. 14 U.N. GAOR, Supp. No. 1A (A/4132/Add. 1). 
undertaken with the consent of the Governments involved, but were carried out without the formal acquiescence of other U.N. organs. ${ }^{1154}$

The discretionary nature of Article 99 confers upon the SecretaryGeneral the right and freedom to choose the precise means to be adopted in responding to particular situations. ${ }^{\mathbf{1 1 5 5}} \mathrm{He}$ may, as a matter of strategy, so exert his influence that it will not be necessary for him to formally bring a matter to the attention of the Security Council. ${ }^{1156}$ "In other words, Article 99 may be interpreted as providing a specific legal authorization for the extensive, informal, behind-the-scenes political activities of the Secretary-General that go by the name good offices.",1157

In critically examining, and affirming the constitutional validity of "good offices" actions by the Secretary-General, Hammarskjöld stated that such actions fell within the competence of his office and were in strict accordance with the Charter, when they served its purpose. ${ }^{\mathbf{1 1 5 8}}$ United Nations Charter Article 1(1) provides that it is one of the purposes of the Organization, "to bring about by peaceful means, and in conformity with the principles of justice and international law, adjustment or settlement of international disputes or situations which might lead to a breach of the peace."

1154. Id. at 3 .

1155. Nayar, Dag Hammarskjöld and U Thant: The Evolution of their Office, CASE W. RES. J. INT'L L., VOL. 7, NO. 1 (WINTER 1974), supra note 1086, at 52-53.

1156. Id. at 53 .

1157. Nayar, Dag Hammarskjöld and U Thant: The Evolution of their Office, CASE W. RES. J. INT'L L., VOL. 7, No. 1 (WINTER 1974), supra note 1086, at 53.

1158. 14 U.N. GAOR, Supp. No. 1A (A/4132/Add. 1), at 3.

1159. U.N. Charter, Article 1(1). 
The principle stated in Article 1(1) is clarified in Charter Article 33, which provides that:

[t]he parties to any dispute, the maintenance of which is likely to endanger the maintenance of international peace and security, shall, first of all, seek a solution by negotiation, enquiry, mediation, conciliation, arbitration, judicial settlement, resort to regional agencies or arrangements, or other peaceful means of their own choice. ${ }^{\mathbf{1 1 6 0}}$

As already noted in this study, ${ }^{\mathbf{1 1 6 1}}$ Article 99 empowers the SecretaryGeneral to conduct investigatory and exploratory activities to evaluate whether a particular matter has the potential to threaten the maintenance of international peace and security. If such potential is determined to exist in a given case, the Secretary-General's actions under Article 99 could occur concurrently with the endeavors of parties involved in a conflict to resolve their differences by peaceful means under Article 33. In such a case, the Secretary-General could take the initiative of offering the parties assistance; or he could be asked by the parties in conflict for his assistance and expertise in resolving issues involved in the conflict. "Thus a combined reading of Articles 33 and 99 gives a legal basis for the Secretary-General's good offices.",1162

(2) Creative Diplomatic Options for the Secretary-General: Quiet Diplomacy, Preventive Diplomacy, \& U.N. Presence

The Secretary-General's "good offices" are associated with the closely related concepts of "quiet diplomacy," "preventive diplomacy," and "UN presence." The notion of "quiet diplomacy" involves an appeal to the

1160. U.N. Charter, Article 33.

1161. See supra notes 1134-1135.

1162. Nayar, Dag Hammarskjöld and U Thant: The Evolution of their Office, CASE W. RES. J. INT'L L., VOL. 7, No. 1 (WINTER 1974), supra note 1086, at 52-54. 
international community to utilize the facilities of the United Nations for discreet, private, behind-the-scenes discussions of all outstanding issues. ${ }^{1163}$ The concept of "preventive diplomacy" involves the idea that an essential justification for the presence of the United Nations in the arena of world politics is its ability to quickly intervene in, and effectively resolve local disputes, thereby minimizing the likelihood of intervention in such disputes by major powers. ${ }^{1164}$ The notion of "UN presence" involves the understanding that for the U.N. to succeed in "preventive diplomacy," its presence will be of crucial importance in many cases, and that this necessitates a dynamic role for the Organization, rather than a simply passive part as conference machinery. ${ }^{1165}$

Hammarskjöld is credited with the creative authorship of these concepts, appearing as the architect of the concepts of combined public and private diplomacy within the framework of the United Nations. ${ }^{\mathbf{1 1 6 6}}$ In a 1955 address delivered at the University of California at Berkeley, he spoke of the role of quiet diplomacy in the context of Article 99 initiatives:

Even this last function of the Secretariat - and by necessity especially of the Secretary-General personally - is and should be unspectacular. The very rules of the game, and the specific position of the Secretariat inside the system, force the Secretariat in its activities as representative of the Organization as a whole to apply what is now often called quiet diplomacy. Such an activity, in fact, comes very close to that of a Foreign Office, working along

1163. Nayar, Dag Hammarskjöld and U Thant: The Evolution of their Office, CASE W. RES. J. INT'L L., VOL. 7, NO. 1 (WINTER 1974), supra note 1086, at 54. 1164. Id.

1165. Nayar, Dag Hammarskjöld and U Thant: The Evolution of their Office, CASE W. ReS. J. INT’L L., Vol. 7, No. 1 (WINTER 1974), supra note 1086, at 54. 1166. Id. 
classical lines as a servant of the Government and of the people with a discretion and integrity rendered necessary by the fact that none of the interests it is there to safeguard and none of the confidences that it may be privileged to enjoy, is its own property but something entrusted to it by its master, the people. ${ }^{1167}$

An essential aspect of the concept of "preventive diplomacy" is the independent position of the United Nations and the Secretary-General, as explained by Hammarskjöld in his speech to a Students Association in Copenhagen, Denmark, on May 2, 1959:

To the extent that events have led the governments to accord an independent position as spokesman of the United Nations to the Secretary-General even politically, this has also given him wider opportunities for independent diplomatic activity. . . .

[W] hat I should like to call active preventive diplomacy. . . may be conducted by the United Nations, through the SecretaryGeneral or in other forms, in many situations where no government or group of governments and no regional organization would be able to act in the same way. That such interventions are possible for the United Nations is explained by the fact that . . . the organization has begun to gain a certain independent position, and that this tendency has led to the acceptance of an independent political and diplomatic activity on the part of the Secretary-General as the "neutral" representative of the Organization. ${ }^{1168}$

The role of the Secretary-General as a third-party intervenor (negotiator, "good offices" bearer, or mediator), in conjunction with transfers of matters at issue to the forum of the United Nations Secretariat could significantly relieve

1167. Dag Hammarskjöld, International Cooperation within the United Nations, Address at the the University of California, Berkeley, June 25, 1955, in SERVANT OF PEACE: A SELECTION OF THE SPEeChES AND StATEMENTS OF DAG HAMMARSKÖLD, 94-95 (Wilder Foote ed. 962), supra note 1085, at 94-95.

1168. Dag Hammarskjöld, Do We Need the United Nations? Address before the Students Association, Copenhagen, Denmark, May 2, 1959, in SERVANT OF PEACE: A SElection of THE SPeECHES AND STATEMENTS OF DAG HAMMARSKÖLd, 210 (Wilder Foote ed. 1962), supra note 1085, at 210. 
difficulties encountered in situations of conflict between nations. ${ }^{1169}$ Typically, in these situations, there is a tendency for parties in conflict to engage in processes of bargaining, with weaker entities being thereby placed in unfavorable positions, and objectively just resolutions being difficult to attain. ${ }^{\mathbf{1 1 0}}$ The dangers of deadlock are frequently present in these situations, and the complexities of issues may defeat the best efforts of the parties. ${ }^{1171}$

However, if diplomatic negotiations are transferred to the forum of the United Nations, and facilitated by the Secretary-General, the chances of objective settlements of issues will be significantly improved, since the parties will function within the framework of the U.N. Charter and its principles. ${ }^{1172}$ In this setting the bargaining discretion of parties in conflict will be moderated by a multilateral approach to problems, in which all U.N. members will have a direct or indirect influence, and the unfavorable positions of weaker states can be improved by bargaining carried out against the background of larger U.N. interests. ${ }^{\mathbf{1 1 3}}$ Further, the danger of deadlocks can be reduced with the help of the SecretaryGeneral, and the complexity of problems appropriately mitigated with the assistance of the Secretariat which can place its resources at the disposal of the parties. ${ }^{1174}$

1169. Nayar, Dag Hammarskjöld and U Thant: The Evolution of their Office, CASE W. RES. J. INT’L L., VOL. 7, No. 1 (WINTER 1974), supra note 1086, at 55. 1170. Id.

1171. Nayar, Dag Hammarskjöld and U Thant: The Evolution of their Office, CASE W. RES. J. INT’L L., VOL. 7, No. 1 (WINTER 1974), supra note 1086, at 55. 1172. Id.

1173. Id.

1174. Nayar, Dag Hammarskjöld and U Thant: The Evolution of their Office, CASE W. RES. J. INT’L L., VOL. 7, NO. 1 (WINTER 1974), supra note 1086, at 55-56. 
(3) The Secretary-General's Right \& Duty to Act Independently, Derived from his Inherent Responsibilities as the Head of a a Principal Organ

A joint reading of Articles 7 and 99 provides justification for action by the Secretary-General without instructions from principal organs, and his right and duty to undertake such action when the systems set up to maintain international peace and security have demonstrated deficiencies in their functions. ${ }^{1175}$ It was Hammarskjöld's view that, "the Secretary-General shall be the organ of the United Nations which can bring the United Nations out of deadlock."1176

On the question of whether the Secretary-General should be expected to act if no guidance for his actions can be found either in the Charter or in decisions of the main organs of the United Nations, Hammarskjöld stated:

. . I believe that it is in keeping with the philosophy of the Charter that the Secretary-General should be expected to act also without such guidance, should this appear to him necessary in order to help in filling any vacuum that may appear in the systems which the Charter and traditional diplomacy provide for the safeguarding of peace and security. ${ }^{1177}$

When the Security Council was deadlocked because of a Soviet veto, over Lebanon's complaint of intervention in its internal affairs by the United Arab Republic (UAR), Hammarskjöld made the following statement in the Security Council, clearly conveying his sense of responsibility for the situation:

1175. Id.

1176. Nayar, Dag Hammarskjöld and U Thant: The Evolution of their Office, CASE W. RES. J. INT'L L., VOL. 7, No. 1 (WINTER 1974), supra note 1086, at 56 Cf. Lash, Hammarskjöld's Conception of his Office, 16 INT'L ORGANIZATION 551 (1962-63).

1177. U.N. GAOR, 690th Plenary meeting, Sep. 26, 1957, III 72-73. 
The Security Council has just failed to take additional action in the grave emergency facing us. However, the responsibility of the United Nations to make all efforts to live up to the purposes and Principles of the Charter remains. ... .

I am sure that I will be acting in accordance with the wishes of the members of the Council if I . . . use all opportunities offered to the Secretary-General, within the limits set by the Charter and towards developing the United Nations effort, so as to help to prevent a further deterioration of the situation in the Middle East. . . .

First of all . . . this will mean further development of the Observation Group [ in Lebanon ]. The Council will excuse me for not being able to spell out at this moment what it may mean beyond that. ${ }^{1178}$

In the foregoing statement, Hammarskjöld forcefully expressed his sense of the Secretary-General's inherent responsibilities, deriving from his position as head of one of the principal organs of the United Nations committed to upholding the purposes and principles of the Organization. ${ }^{1179}$ The significance of the statement is in the fact that it identifies a legitimate alternate basis for many actions of the Secretary-General which can only be justified with great difficulty under specific grants of authority in provisions of the Charter or resolutions of the principal organs. ${ }^{1180}$ The particular powers of the Secretary-General, referenced in Hammarskjöld's statement are generally diplomatic in nature. ${ }^{1181}$

In going forward with his mission in 1954 to free United States airmen held by Communist China, Hammarskjöld was compelled, by the exigencies of of the situation, to invoke his general authority under the Charter, because

1178. U.N. SCOR, 837th meeting, Jul. 22, 1958, IIT 10-16.

1179. Nayar, Dag Hammarskjöld and U Thant: The Evolution of their Office, CASE W. RES. J. INT'L L., VOL. 7, NO. 1 (WINTER 1974), supra note 1086, at 57.

1180. Id.

1181. Id. 
the Peking Government had refused to recognize the validity of the U.N. General Assembly Resolution under which the Secretary-General had commenced his action. ${ }^{1182}$ Hammarskjöld explained the legitimate basis of his action, in the following terms:

The Peking Formula meant that if an organ of the United Nations asks the Secretary-General to do something and does so without delegating its authority, he has only the authority vested in him under the Charter. The resolution is only an instruction to him to use the authority he has under the Charter, although he is, of course, guided by the resolution. ${ }^{\mathbf{1 1 3}}$

There have been other instances of diplomatic and political functions undertaken by the Secretary-General under his inherent powers. ${ }^{\mathbf{1 1 8 4}}$ The implicit principle in such cases is the doctrine that the Secretary-General's authority is autonomous and coordinate with that of the other U.N. principal organs, and derived from the Charter as a whole. ${ }^{\mathbf{1 1 8 5}}$

Article 99 was used to significant effect by Dag Hammarskjöld in the Congo crisis of 1960. It is noteworthy that, notwithstanding the powers granted to the Secretary-General by Article 99, he is subject to the practical limitation that his political position is typically not sufficiently strong to enable him to oppose a major power. ${ }^{1186}$ In the Congo crisis of 1960, however, there was no opposition to the Secretary-General's invoking of Article 99, since all the African States as

1182. Nayar, Dag Hammarskjöld and U Thant: The Evolution of their Office, CASE W. RES. J. INT'L L., VOL. 7, No. 1 (WINTER 1974), supra note 1086, at 57. 1183. Id.

1184. Nayar, Dag Hammarskjöld and U Thant: The Evolution of their Office, CASE W. RES. J. INT’L L., VOL. 7, No. 1 (WINTER 1974), supra note 1086, at 58. 1185. Id. 1186. Id. 
well as the permanent members of the U.N. Security Council actively supported the action. ${ }^{1187}$

The question as to the authority to be entrusted with interpretation of the U.N. Charter was considered by Committee IV/2 at the San Francisco Conference of $1945{ }^{1188}$ In addressing the issue, the Committee stated:

In the course of the operations from day to day of the various organs of the Organization, it is inevitable that each organ will interpret such parts of the Charter as are applicable to its particular functions. This process is inherent in the functioning of any body which operates under an instrument defining its functions and powers. ${ }^{1189}$

In accordance with the Committee's pronouncement, the Secretary-

General, as a principal organ of the Organization, construes his own legal powers, and applies the Charter or other rules of law to particular situations. ${ }^{1190}$

Dag Hammarskjöld's contribution to the development of the political role of the Secretary-General derives mainly from the fact that he rejected "a restrictive literal interpretation" of the Charter, and favored a "freer interpretation," as indicated by the following statement: ${ }^{1191}$

The statement of objectives in the Charter is binding, and so are the rules concerning the various organs and their competence, but it is not necessary to regard the procedures in the Charter as limitative in purpose. They may be supplemented by others under the pressure of circumstances and in the light of experience. This freer interpretation permits an evolution depart-

1187. Nayar, Dag Hammarskjöld and U Thant: The Evolution of their Office,

CASE W. RES. J. INT’L L., VOL. 7, No. 1 (WINTER 1974), supra note 1086, at 58-59.

1188. U.N.C.I.O. Docs. 668 (1945).

1189. Id.

1190. Id.

1191. Nayar, Dag Hammarskjöld and U Thant: The Evolution of their Office, CASE W. RES. J. INT’L L., VOL. 7, No. 1 (WINTER 1974), supra note 1086, at 59. 
ing from what has been explicitly stated, to the extent that new procedures, perhaps modified with a modified balance in the use of various organs, prove productive in practice for the efforts to attain the objectives of the Charter. . . . What we are seeing is an evolution . . . of a fundamental charter of sufficient flexibility to permit a continuous adaption of constitutional life to the needs. ${ }^{1192}$

\section{H. Summation}

A survey of scientific and technological processes and products provides reasonable grounds for an assessment that the state of technology has progressed to the point that materials, products, and processes exist in the modern world to enable a concerted, steady-paced transition from the current non-renewable energy resources, to wind, solar, and other "green" technologies for the generation

of all required power. ${ }^{\mathbf{1 1 9 3}}$ However, issues of executive leadership of the Sustainable Development Initiative of General Assembly Resolution A/RES/70/1 remain. In view of the special attributes of international stature, neutrality, independence, and diplomacy called for in the leadership of the Sustainable Development Initiative, the U.N. Secretary-General appears eminently suited for the position. Statements regarding the state of implementation of the Sustainable Development Initiative of General Assembly Resolution A/RES/70/1 were issued in January 2019, by Mr. Ban Ki-moon, former UN Secretary-General, Ms. Helen

1192. Dag Hammarskjöld, Do We Need the United Nations? Address before the Students Association, Copenhagen, Denmark, May 2, 1959, in Servant of PEACE: A SElECtion OF THE SPEECHES AND STATEMENTS OF DAG HAMMARSKÖLD (Wilder Foote ed. 1962), supra note 1085, at 211.

1193. See supra text accompanying notes 1041-1045. 
Clark, a former Prime Minister of New Zealand, and Mr. Jeffrey D. Sachs, Director of the UN Sustainable Development Solutions Network (SDSN). ${ }^{1194}$ These pronouncements pointed to serious deficiencies in the implementation to date of the Initiative three years after its commencement. ${ }^{1195}$ The statements indicate, that the primary impediment to the implementation of the 17 goals and 169 subsidiary tasks of General Assembly Resolution A/RES/70/1 is the absence of effective executive leadership to: (a) formulate and execute a collaborative global implementation plan; and (b) deal effectively with political, scientific, technical, financial, and other issues in the implementation process. ${ }^{\mathbf{1 1 9 6}}$

Provisions of General Assembly Resolution A/RES/70/1 specify particular responsibilities for the UN Secretary-General as a high-level administrative officer. ${ }^{1197}$ However, the experience to date of the Sustainable Development Initiative indicates the critically important need for an executive leader, rather than an administrative head. The Secretary-General is defined in Article 97 of the UN Charter as the Chief Administrative Officer of the entire UN Organization. ${ }^{1198}$ Articles 98 and 99 of the UN Charter grant the Secretary-General political powers. ${ }^{1199}$ The question arises as to whether the Secretary-General can so

1194. Megan Rowling, Global Leadership Deficit Leaves Development Goals in Doldrums, REUTERS, Jan. 17, 2019, supra note 1062, https://www.reuters.com/article/us-global-development-climatechange/globalleadership-deficit-leaves-development-goals-in-doldrums-idUSKCN1PB2UM 1195. Id. 1196. Id.

1197. U.N. General Assembly Resolution A/RES/70/1, supra note 17.

1198. U.N. Charter, Article 97.

1199. U.N. Charter, Articles 98, 99.. 
construe his powers under the UN Charter and other relevant sources, as to function as executive leader of the Sustainable Development Initiative of General Assembly Resolution A/RES/70/1. ${ }^{\mathbf{1 2 0 0}}$

An examination of the history of the evolution of the position of UN Secretary-General reveals that its powers are not fixed and static, but can be dynamically construed by an incumbent from the principles of the UN Charter, prevailing legal doctrine accepted by States generally, the opinions of U.N. member states as articulated by their permanent representatives, and his own responses to particular exigencies he encounters in the performance of his duties. ${ }^{\mathbf{1 2 0 1}}$ The insights and actions of the distinguished second SecretaryGeneral, Dag Hammarskjöld, are of great value in illuminating this mode of functioning of an incumbent in the office of Secretary-General.

Hammarskjöld rejected "a restrictive literal interpretation" of the Charter, and favored a "freer interpretation." of the powers of his office ${ }^{\mathbf{1 2 0 2}}$ In the process, he contributed significantly to the evolution of the office of United Nations Secretary-General in its early formative stages. The experience to date of the Sustainable Development Initiative indicates that special qualities of executive leadership will be required for its successful implementation, and that the office of Secretary-General will need to develop, expand, and grow significantly to meet the complex demands and exigencies of the Initiative.

1200i U.N. General Assembly Resolution A/RES/70/1, supra note 17.

1201. Nayar, Dag Hammarskjöld and U Thant: The Evolution of their Office, CASE W. RES. J. INT'L L., VOL. 7, NO. 1 (WINTER 1974), supra note 1086, at 45.

1202. Nayar, Dag Hammarskjöld and U Thant: The Evolution of their Office, CASE W. RES. J. INT'L L., VOL. 7, NO. 1 (WINTER 1974), supra note 1086, at 59. 


\section{CONCLUSION}

\section{A. Introduction}

Preceding parts of this work have examined the evolution of the conceptual framework of "Sustainable Development," with its three dimensions of economic growth, social development, and environmental protection. The material presented has centered on United Nations General Assembly Resolution A/RES/70/1, "Transforming Our World: the 2030 Agenda for Sustainable

Development.”,1203 Resolution A/RES/70/1, which came into force on January 21, 2016, presents 17 "Sustainable Development Goals (SDGs) and 169 subsidiary targets., $\mathbf{1 2 0 4}$

Chapter V provides a final summation of the work, with particular reference to projected leadership roles of the U.N. and its Secretary-General in a collaborative international effort at resolution of the issues of Sustainable Development.

\section{B. The Concept of "Sustainability"}

The discipline of sustainability is based primarily on principles enunciated in 1987 by the World Commission on Environment and Development (WCED: "The Brundtland Commission"). ${ }^{\mathbf{1 2 0 5}}$ In its report, the Commission observed that the development path required was "... one that sustained human progress not

1203. U.N. General Assembly Resolution A/RES/70/1, supra, note 1.

1204. Id.

1205. REPORT OF THE WORLD COMMISSION ON ENVIRONMENT AND DEVELOPMENT: OUR COMMON FUTURE, http://www.un-documents.net/our-common-future.pdf (last visited Feb. 8, 2017), supra note 45. 
just in a few places for a few years, but for the entire planet into the distant future.",1206

At a U.N. special summit in September 2015, world leaders articulated an ambitious plan encompassing a set of 17 goals and 169 targets to end poverty, reduce inequalities, and protect the environment. The leaders' new plan came into effect on January 21, 2016, effectively replacing the Millennium Development Goals ("MDGs"). ${ }^{\mathbf{1 2 0 7}}$ The "New Universal Agenda" was proclaimed to be aimed at realizing "the human rights of all," and its provisions were declared to "balance the three dimensions of sustainable development: the economic, social and environmental.,"1208

\section{Issues of "Sustainability"}

The Fifth Report of the Intergovernmental Panel on Climate Change (IPCC), first published in 2015, stated that there is clear evidence of the impact of human activity on the Earth's climate system, adding that recent anthropogenic emissions of greenhouse gases have been the highest in history. ${ }^{\mathbf{1 2 0 9}}$

Mr. Jeffrey D. Sachs, Director of the U.N. Sustainable Developments Network notes that the frequency and severity of climate-related threats worldwide have risen dramatically, and are likely to increase still further. ${ }^{\mathbf{1 2 1 0}}$ He quotes

1206. REPORT OF THE WORLD COMMISSION ON ENVIRONMENT AND DEVELOPMENT: OUR COMMON FUTURE, http://www.un-documents.net/our-common-future.pdf (last visited Feb. 8, 2017), at Chap. I, § 1, II 10, supra note 46.

1207. United Nations General Assembly Resolution A/RES/70/1 (2015), supra note 1.

1208. Id. at Preamble II 3

1209. IPCC, 2014: Climate Change 2014: Synthesis Report, supra note 147, at 40.

1210. SACHS, THE AGE OF SuSTAINABLE DEVELOPMENT (2015), supra note 73, at 37. 
scientific views as indicating that human-induced changes, caused in large part by the use of fossil fuels, are driving the Earth's physical and biological changes. ${ }^{\mathbf{2 1 1}}$

According to the Intergovernmental Panel on Climate Change (IPCC), adaptation options exist in all sectors, but their context for implementation and potential to reduce climate-related risks, differs across sectors and regions. ${ }^{\mathbf{1 2 1 2}}$ Mitigation options are available in every major sector, and can be more costeffective if employed in an integrated approach that combines measures to reduce energy use and the greenhouse gas intensity of end-use sectors, to decarbonize energy supplies, reduce net emissions and enhance carbon sinks in land-based sectors. ${ }^{1213}$

The IPCC observes that the effectiveness of adaptation and mitigation responses will depend on policies and measures employed across multiple planes of endeavor: international, regional, national and sub-national. ${ }^{1214}$ Policies across all planes, supporting technology development, diffusion and transfer, as well as finance for responses to climate change, can complement and supplement the effectiveness of policies that directly promote adaptation and mitigation. ${ }^{\mathbf{2 1 5}}$

\section{B. The Role of the United Nations}

In his Copenhagen address of May 2, 1959, the distinguished second Secretary-General of the United Nations, Dag Hammarskjold, depicted the

1211. SACHS, The Age Of Sustainable DeVElopment (2015), supra note 73, at 34-35.

1212. IPCC, 2014: Climate Change 2014: Synthesis Report, supra note 145, at 95.

1213. Id. at 98 .

1214. Id. at 102 .

1215. Id. 
U.N. as having "an existence and possibilities of action independent of the will of the of the member governments, and the policies of the member states themselves." "more than the sum of its parts." He asserted that the Organization had increasingly developed "an independent position," rooted in "the existence of an opinion independent of partisan interests and dominated by the objectives indicated in the United Nations Charter.,"1217

Hammarskjöld, rejected "a restrictive literal interpretation" of the U.N. Charter, and favored a "freer interpretation." of the powers of his office ${ }^{1218}$ In the process, he contributed significantly to the evolution of the office of United Nations Secretary-General in its early formative stages. The experience to date of the Sustainable Development Initiative indicates that special qualities of executive leadership will be required for its successful implementation, and that the office of Secretary-General will need to develop, expand, and grow significantly to meet the complex demands and exigencies of the Initiative.

Despite undeniable shortcomings of organization and structure, Resolution $\mathrm{A} / \mathrm{RES} / 70 / 1$ represents a remarkable achievement, in that it clearly lays out the perils that confront the world community of nations if coordinated corrective measures are not implemented on an urgent and comprehensive basis to meet the

1216. M. G. Kaladharan Nayar, Dag Hammarskjöld and U Thant: The Evolution of their Office, CASE W. RES. J. INT’L L., VOL. 7, No. 1 (WINTER 1974), at 36, supra note 1090, in UNITED NATIONS REVIEW, June 1959, at 24-25.

1217. Id.

1218. Nayar, Dag Hammarskjöld and U Thant: The Evolution of their Office, CASE W. RES. J. INT’L L., VOL. 7, No. 1 (WINTER 1974), supra note 1090, at 59. 
needs of sustainable development in its three dimensions of economic growth, social development, and environmental protection. ${ }^{\mathbf{1 2 1 9}}$ These measures will require worldwide coordination, collaboration, and cooperation on a scale not hitherto attempted in any major undertaking in world history. The primary rationale for the envisaged role of the U.N. in the undertaking, is that, as demonstrated in material presented in earlier parts of this writing, the goals of Resolution A/RES/70/1 essentially encompass human rights. Article 55(c) of the U.N. Charter states: “. . . the United Nations shall promote: . . universal respect for, and observance of, human rights and fundamental freedoms for all without distinction as to race, sex, language, or religion."1220 By Article 56, “[a]11 Members pledge themselves to take joint and separate action in cooperation with the Organization for the achievement of the purposes set forth in Article 55.,

Each Member State of the United Nations, by becoming a party to the Charter, has accepted legal obligations in the effort to promote universal respect for, and observance of, human rights and fundamental freedoms for all without distinction as to race, sex, language, or religion. The term "pledge" in Article 56 clearly indicates that Member States have accepted an international obligation for objectives specified in Article 55. ${ }^{\mathbf{1 2 2 2}}$

1219. REPORT OF THE WORLD COMMISSION ON ENVIRONMENT AND DEVELOPMENT: OUR COMMON FUTURE, http://www.un-documents.net/our-common-future.pdf (last visited Feb. 8, 2017), at Chap. I, § 1, II 10, supra note 46.

1220. U.N. CHARTER art. 55(c).

1221. U.N. CHARTER art. 56.

1222. See generally Schwelb, The International Court of Justice and the Human Rights Clauses of the Charter, 65 AM. J. INT'L L. 337 (1972). 
Mr. Hersch Lauterpacht, distinguished jurist, eminent practitioner of international law, and judge of the International Court of Justice (1955-1960), made the following statement in regard to the status of fundamental human rights affirmed by the Charter of the United Nations:

The Charter of the United Nations is a legal document; its language is the language of law, of international law. In affirming repeatedly the 'fundamental human rights' of the individual it must of necessity be deemed to refer to legal rights - to legal rights recognised by international law and independent of the law of the State. ${ }^{\mathbf{1 2 2 3}}$

Mr. Lauterpacht, made the following statement in regard to the scope and magnitude of legal obligations to promote the observance of human rights, mandated by the Charter of the United Nations: "The provisions of the Charter ... impose legal obligations not only upon the Members of the United Nations. They imply a comprehensive legal obligation upon the United Nations as a whole."

It is an inescapable principle of interpretation that whenever an international instrument defines, in its constitution, the purposes of its being, the right and obligation to give effect to those purposes are inherent in it and nothing short of an express derogation from that implicit authority can legitimately restrict the powers and obligations in question. ${ }^{\mathbf{2 2 5}}$

. . . [O]ne of the results of the provisions of the Charter in the matter of human rights and fundamental freedoms is to effect a far-reaching change in the position of the individual in interrnational law. If these provisions of the Charter constitute legal rights and obligations, then they signify the recognition, in an international treaty of wide generality, of rights of the individual as such. ${ }^{\mathbf{1 2 6}}$

1223. LAUTERPACHT, supra note 664 , at 34.

1224. Id.

1225. Id.

1226. Id. 


\section{F. The Current Situation}

"Three years after the Sustainable Goals were announced and presented to the world, the report of implementation is not satisfactory." said former UN Secretary-General Mr. Ban Ki-moon, at the March 2019 Boao Forum, an event held annually in the Hainan Province of China, "We need global concerted action; then we have to work for common development in accordance with

Sustainable Development Goals United Nations has presented to the world."1227 A similar assessment was offered by Ms. Helen Clark, a former Prime Minister of New Zealand, at a meeting held in January 2019 at Madrid, hosted by the Government of Spain. ${ }^{\mathbf{1 2 2 8}}$ Ms. Clark, who headed the United Nations Development Program (UNDP) from 2009 to 2017, said that, because of delays in implementation, the Sustainable Development Goals (SDGs) [agenda] . . . "has gone under the radar."1229

Ms. Clark stated that the number of hungry people in the world had risen three years in a row after previous reductions, a fact that, she felt, was "undoubtedly related to climate change and displacement." under current estimates, 6 percent of the global population - or close to half a billion people - would still be living in extreme poverty by the year $2030 .^{\mathbf{1 2 3 1}}$

1227. Megan Rowling, Global Leadership Deficit Leaves Development Goals in Doldrums, REUTERS, Jan. 17, 2019, supra note 1062, https://www.reuters.com/article/us-global-development-climate-changeglobal-leadership-deficit-leaves-development-goals-in-doldrums-

1228. Id. idUSKCN1PB2UM

1229. Id.

1230. Id.

1231. Id. 
Ms. Clark pointed to changes in the world's "political landscape" as another factor that has made the 2030 goals "more elusive."1232 She stated that the unity of the international community that had allowed the SDGs and Paris Agreement on climate change to be adopted in 2015 had been "shattered" by these shifts. ${ }^{1233}$ She noted, further, that the political shifts had taken the pressure off certain nations to act, including China and India, both of which were still continuing to invest in coal-fired power plants although they were signaling a shift away from "dirty" energy. ${ }^{\mathbf{1 2 3 4}}$

At the same event in Madrid, Mr. Jeffrey D. Sachs, who is currently one of the UN SDG Advocates appointed by the Secretary-General, expressed concern over the fact that "'nothing' had happened at the global level in the past three years."1235 Mr. Sachs, Director of the UN Sustainable Development Solutions Network (SDSN), assigned responsibility for lack of progress on the SDGs and the Paris Agreement to "a dearth of leadership, the unfairness of the global economic system, and the fact that there was essentially no plan for putting the 2015 agenda of General Assembly Resolution A/RES/70/1 into practice.”, He suggested that the introduction of a worldwide "wealth tax" on billionaires could be a means of "getting education to every child on the planet.",1237

1232. Megan Rowling, Global Leadership Deficit Leaves Development Goals in Doldrums, REUTERS, Jan. 17, 2019, supra note 1062, https://www.reuters.com/article/us-global-development-climatechange-global-leadership-deficit-leaves-development-goals-in-doldrumsidUSKCN1PB2UM

1233. Id.

1234. Id.

1235. Id.

1236. Id.

1237. Id. 


\section{F. The Need for Executive Leadership in Implementation of SDGs}

The foregoing assessments, of Mr. Ban Ki-moon, former UN SecretaryGeneral, Ms. Helen Clark, a former Prime Minister of New Zealand, and Mr. Jeffrey D. Sachs, Director of the UN Sustainable Development Solutions Network (SDSN), seem to indicate, directly or by implication, that the primary impediment to the implementation of the 17 goals and 169 subsidiary tasks of UN General Assembly Resolution A/RES/70/1 is the absence of effective executive leadership to: (a) formulate and execute a collaborative global implementation plan; and (b) deal effectively with political, scientific, technical, financial, and other issues that can be expected to appear in the course of implementation. ${ }^{1238}$ The question arises, therefore, whether, executive leadership for an SDG Initiative can be sought in the person of the UN Secretary-General, who has been designated the Chief Administrative Officer of the entire UN Organization in Article 97 of the UN Charter, and who has been granted significant political powers under Articles 98 and 99 of the UN Charter. ${ }^{1239}$

In the material that follows, Resolution $\mathrm{A} / \mathrm{RES} / 70 / 1$ is scrutinized to ascertain whether an executive role, or its equivalent, for the Secretary-General has been specified in its provisions. ${ }^{\mathbf{1 2 4 0}}$ As a related matter, the question arises as to whether the Secretary-General can so construe his powers under the

1238. Megan Rowling, Global Leadership Deficit Leaves Development Goals in Doldrums, REUTERS, Jan. 17, 2019, supra note 1062, https://www.reuters.com/article/us-global-developmentclimatechange/global-leadership-deficit-leaves-development-goals-indoldrums-idUSKCN1PB2UM

1239. U.N. CHARTER articles 97, 98, 99.

1240. U.N. General Assembly Resolution A/RES/70/1, supra note 17. 
UN Charter and other relevant sources, as to function as executive leader of the Sustainable Development Initiative of Resolution A/RES/70/1. ${ }^{1241}$

An examination of the history of the evolution of the position of UN Secretary-General reveals that its powers are not static, but can be dynamically construed by an incumbent from the principles of the UN Charter, prevailing legal doctrine accepted by States generally, the opinions of U.N. member states as articulated by their permanent representatives, and his own responses to particular exigencies he encounters in the performance of his duties. ${ }^{\mathbf{1 2 4 2}}$ The insights and actions of the distinguished second Secretary-General, Dag Hammarskjöld, illuminate this mode of functioning of an incumbent Secretary-General.

Hammarskjöld rejected "a restrictive literal interpretation" of the Charter, and favored a "freer interpretation." of the powers of his office ${ }^{\mathbf{1 2 4 3}}$ In the process, he contributed significantly to the evolution of the office of United Nations Secretary-General in its early formative stages. The experience to date of the Sustainable Development Initiative indicates that special qualities of executive leadership will be required for its successful implementation, and that the office of Secretary-General will need to develop, expand, and grow significantly to meet the complex demands and exigencies of the Initiative.

1241. U.N. General Assembly Resolution A/RES/70/1, supra note 17.

1242. Nayar, Dag Hammarskjöld and U Thant: The Evolution of their Office, CASE W. RES. J. INT'L L., VOL. 7, No. 1 (WINTER 1974), supra note 1086, at 45.

1243. Nayar, Dag Hammarskjöld and U Thant: The Evolution of their Office, CASE W. RES. J. INT'L L., VOL. 7, NO. 1 (WINTER 1974), supra note 1086, at 59. 


\section{J. Final Summation of Argument}

A survey of scientific and technological processes and products provides reasonable grounds for an assessment that the state of technology has progressed to the point that materials, products, and processes exist in the modern world to enable a concerted, steady-paced transition from the current non-renewable energy resources, to wind, solar, and other "green" technologies for the generation of all required power. ${ }^{\mathbf{1 2 4 4}}$ However, issues of executive leadership of the Sustainable Development Initiative of General Assembly Resolution A/RES/70/1 remain. In view of the special attributes of international stature, neutrality, independence, and diplomacy called for in the leadership of the Sustainable Development Initiative, it is suggested that the U.N. Secretary-General appears eminently suited for the position.

Statements regarding the state of implementation of the Sustainable Development Initiative of General Assembly Resolution A/RES/70/1 were issued in January 2019, by Mr. Ban Ki-moon, former UN Secretary-General, Ms. Helen Clark, a former Prime Minister of New Zealand, and Mr. Jeffrey D. Sachs, Director of the UN Sustainable Development Solutions Network (SDSN). ${ }^{\mathbf{1 2 4 5}}$ These pronouncements pointed to serious deficiencies in the implementation to date of the Initiative three years after its commencement. ${ }^{\mathbf{1 2 4 6}}$ The statements

1244. See supra text accompanying notes 1041-1045.

1245. Megan Rowling, Global Leadership Deficit Leaves Development Goals in Doldrums, REUTERS, Jan. 17, 2019, supra note 1062, https://www.reuters.com/article/us-global-developmentclimatechange/global-leadership-deficit-leaves-development-goals-in-doldrumsidUSKCN1PB2UM

1246. Id 
indicate, directly and by implication, that the primary impediment to the implementation of the 17 goals and 169 subsidiary tasks of General Assembly Resolution A/RES/70/1 is the absence of effective executive leadership to:

(a) formulate and execute a collaborative global implementation plan; and (b) deal effectively with political, scientific, technical, financial, and other issues in the implementation process. ${ }^{\mathbf{1 2 4 7}}$

Provisions of General Assembly Resolution A/RES/70/1 specify particular responsibilities for the UN Secretary-General as a high-level administrative officer. $^{1248}$ However, the experience to date of the Sustainable Development Initiative indicates the critically important need for an executive leader, rather than an administrative head. The Secretary-General is defined in Article 97 of the UN Charter as the Chief Administrative Officer of the entire UN Organization. ${ }^{1249}$ Articles 98 and 99 of the UN Charter grant the Secretary-General political powers. ${ }^{\mathbf{1 2 5 0}}$ The question arises as to whether the Secretary-General can so construe his powers under the UN Charter and other relevant sources, as to function as executive leader of the Sustainable Development Initiative of General Assembly Resolution A/RES/70/1. ${ }^{1251}$

An examination of the history of the evolution of the position of $\mathrm{UN}$

1247. Megan Rowling, Global Leadership Deficit Leaves Development Goals in Doldrums, REUTERS, Jan. 17, 2019, supra note 1062, https://www.reuters.com/article/usglobal-development-climatechange/global-leadership-deficit-leavesdevelopment-goals-in-doldrums-idUSKCN1PB2UM

1248. U.N. General Assembly Resolution A/RES/70/1, supra note 17.

1249. U.N. Charter, Article 97.

1250. U.N. Charter, Articles 98, 99..

1251. U.N. General Assembly Resolution A/RES/70/1, supra note 17. 
Secretary-General reveals that its powers are not fixed and static, but can be dynamically construed by an incumbent from the principles of the UN Charter, prevailing legal doctrine accepted by States generally, the opinions of U.N. member states as articulated by their permanent representatives, and his own responses to particular exigencies he encounters in the performance of his duties. ${ }^{1252}$ The insights and actions of the distinguished second SecretaryGeneral, Dag Hammarskjöld, are of great value in illuminating this mode of functioning of an incumbent in the office of Secretary-General.

Hammarskjöld rejected "a restrictive literal interpretation" of the Charter, and favored a "freer interpretation." of the powers of his office ${ }^{\mathbf{1 2 5 3}}$ In the process, he contributed significantly to the evolution of the office of United Nations Secretary-General in its early formative stages. The experience to date of the Sustainable Development Initiative indicates that special qualities of executive leadership will be required for its successful implementation, and that the office of Secretary-General will need to develop, expand, and grow significantly to meet the complex demands and exigencies of the Initiative.

1252. Nayar, Dag Hammarskjöld and U Thant: The Evolution of their Office, CASE W. RES. J. INT'L L., VOL. 7, No. 1 (WINTER 1974), supra note 1086, at 45.

1253. Nayar, Dag Hammarskld and U Thant: The Evolution of their Office,

CASE W. ReS. J. INT'L L., VOL. 7, No. 1 (WINTER 1974), supra note 1086, at 59. 


\section{BIBLIOGRAPHY}

\section{$\underline{\text { BOOKS \& REPORTS }}$}

1. Ayres, Robert U. \& Edward H. Ayres, CROssing ThE EnERGY Divide, MOVING FROM FOSSIL FUEL DEPENDENCE TO A CLEAN-ENERGY FUTURE (Wharton School Publishing 2009).

2. Black, Maggie \& Jannet King, The ATLAS OF WATER: MAPPING THE WORLD's MOST CRITICAL RESOURCE (University of California Press 2d ed. 2009).

3. Blockstein, David E. \& Leo Wiegman, The Climate Solutions CONSENSUS: WHAT WE KNOW AND WHAT TO DO ABOUT IT (Island Press 2010).

4. Brown, Lester R., Plan B 4.0: Mobilizing TO SAVE CiVilization (W. W. Norton \& Company 2009).

5. Crawford, James, BROWLIE'S PRINCIPLES OF PUBLIC INTERNATIONAL LAW (Oxford University Press 8th ed. 2012) (1998).

6. Cunningham, William P. and Mary Ann Cunningham, ENVIRONMENTAL SCIENCE: A GLOBAL CONCERN (11th ed. McGraw-Hill (2010)).

7. Daly, Herman E. and Joshua Farley, ECOLOGICAL ECONOMICS: PRINCIPLES AND APPLICATIONS (Island Press 2004).

8. Edwards, Andres R., ThE Sustainability REVOlution: PORTRAit OF A PARADIGM SHIFT (New Society Publishers 2005).

9. Evans, J. P., ENVIRONMENTAL GOVERnANCE (Routledge 2012).

10. Flannery, Timothy, THE ETERNAL FrontiER: AN ECOlOGICAL History OF NORTH AMERICA AND ITS PEOPLES (Grove Press 2001).

11. Gore, Al, An Inconvenient Truth: The Crisis of Global Warming (Viking \& Rodale Inc. 2007) (2006).

12. Hammarskjöld, Dag, Do We Need the United Nations?, Address before the Students Association, Copenhagen, Denmark, May 2, 1959, in SERVANT OF PEACE: A SELECTION OF THE SPEECHES AND STATEMENTS OF DAG HAMMARSKJÖLD (Wilder Foote ed., The Bodley Head, 1962). 
13. Henderson, Holley, BeComing a GreEn Professional: A Guide to CAREERS IN SUSTAINABLE ARCHITECTURE, DEVELOPMENT AND OPERATIONS (John Wiley \& Sons, Inc. 2012).

14. Intergovernmental Panel on Climate Change, Climate Change 2007: IMPACTS, ADAPTATIONS AND VULNERABILITY, (M.L. Parry et al. eds., 2007).

15. INT'L UNION FOR THE CONSERVATION OF NATURE \& NATURAL RES., MARINE PROTECTED AREA NEEDS IN THE SOUTH ASIAN SEAS REGION VOL. 1: BANGLADESH at 5 (John C. Pernetta ed., 1993)).

16. Klein, Naomi, This Changes Everything: Capitalism vs The Climate (Simon \& Schuster, Inc. 2015).

17. Kostigen, Thomas M., THE GreEN BluE BoOK (Rodale 2010).

18. Lauterpacht, Hersch, INTERNATIONAL LAW AND HUMAN RIGHTS (Archon Books 1968) (1950).

19. Lovins, Amory, REINVENTING FIRE: BOLD BUSINESS SOLUTIONS FOR THE NEW ENERGY ERA (Chelsea Green Publishing 2011).

20. McDonough, William and Michael Braungart, CRADLE TO CRADLE (North Point Press 2002).

21. Meadows, Donella H., THINKING IN SYSTEMS - A PRIMER (Chelsea Green Publishing 2008).

22. Millennium Ecosystem Assessment, ECOSYSTEMS AND HUMAN WeLLBEING: SYNTHESIS (Island Press 2005).

23. Miller, G. Tyler, Jr. \& Scott E. Spoolman, Living IN THE ENVIRONMENT, CONCEPTS, CONNECTIONS, AND SOLUTIONS (Brooks/Cole 16th ed. 2009) (2007).

24. Ministry of Home AfFairs, Hous. \& EnV'T, Republic OF MALDives, FIRST NATIONAL COMMUNICATION OF THE REPUBLIC OF MALDIVES TO THE UNITED NATIONS FRAMEWORK CONVENTION ON CLIMATE CHANGE (2001)).

25. Ministry of ENV'T \& TRANSP., REPUbliC OF SEYCHELlES, INITIAL NATIONAL COMMUNICATION UNDER THE UNITED NATIONS FRAMEWORK CONVENTION ON CLIMATE CHANGE (2000). 
26. Mitsch, William J. \& James G. Gosselink, WeTLANDS (John Wiley 2007).

27. Mooney, Lelia, Business, Human Rights, AND SustainABILITY SOURCEBOOK (American Bar Association 2015).

28. Moran, Alan (ed.), Climate Change: The Facts (Stockade Books 2015).

29. Pepper, Ian, Charles P. Gerba, \& Mark L. Brusseau, eds., ENVIRONMENTAL AND POLLUTION SCIENCE (Boston Academic Press, 2d ed. 2005).

30. Portney, Kent E., SustainabiLITy (MIT Press 2015).

31. Primack, Richard B., A Primer of CONSERVATION BIOlOGY (Sinauer Associates, Inc. Publishers Sunderland 2008).

32. Randolph, John \& Gilbert M. Masters, ENERGY FOR SUSTAINABILITY TECHNOLOGy PlanNING POLICY (Island Press 2008).

33. Robertson, Margaret, SUSTAINABILITY: PRINCIPLES AND PRACTICE 6 (Routledge 2014).

34. Romm, Joseph, Climate Change, What Everyone NeEds to KnOW (Oxford University Press 2016).

35. Rosenzweig, Michael, WIN-Win ECOLOGY: How thE EARTH'S SPECIES CAN SURVIVE IN THE MIDST OF HUMAN ENTERPRISE (Oxford University Press 2003).

36. Ross, Susan Deller, Women's HUMAN Rights (University of Pennsylvania Press, 2008).

37. Sachs, Jeffrey D., The Age of Sustainable DeVElopment (Columbia University Press 2015).

38. Sandford, Robert William, RESTORING THE FLOW: CONFRONTING THE WORLD'S WATER WOES (Rocky Mountain Books 2009).

39. Schwelb, Egon, HuMAN RIGHTS AND THE INTERNATIONAL COMMUNITY (Quadrangle Books 1964).

40. Simpson, J. A. and Weiner, J., OXFORD ENGLISH DiCTIONARY (Oxford University Press 2009). 
41. Smil, Vaclav, ENERGY AT THE CROSSROADS (MIT Press 2003).

42. Urquhart, Brian, HAMMARSKJŐLD (W. W. Norton \& Company 1972).

43. Ward, Peter Langdon, What Really Causes Global Warming? (Morgan James Publishing 2016).

44. Wilson, Edward O., THE FUtURE OF LIFE (Abacus 2002).

45. Withgott, Jay H. \& Scott R. Brennan, ESSENTIAL ENVIRONMENT: THE SCIENCE BEHIND THE STORIES (3rd ed. Pearson Benjamin Cummings (2009)).

46. WORLD COMMISSION ON ENVIRONMENT AND DEVELOPMENT (WCED), OUR COMMON FUTURE (1987). 


\section{PERIODICAL MATERIALS}

1. Alabi, Saheed A., Climate Change and the Ageing Population: Enforcing the Rights to Life and Health under Human Rights, Health and Climate Change Regimes, Pittsburgh Journal of Environmental and Public Health Law, Vol. 7, Issue 1 (Winter 2012), at 79-126.

2. Brown, Donald A., The Importance of Expressly Examining Global Warming Policy Issues through an Ethical Prism, Penn State Environmental Law Review, Vol. 12, Issue 1 (Winter 2004), at. 147-152, 12 Penn St. Envtl. L. Rev. 147 (2004).

3. Cardwell, Diane, Now Testing the Waters: Wind Power, N.Y. TIMES, January 22, 2017, at [BU] 1 .

4. Congressional Budget Office, Effects of a Carbon Tax on the Economy and the Environment [iii] (May 2013).

5. Congressional Budget Office, Carbon Charges as a Response to Global Warming: The Effects of Taxing Fossil Fuels [xlv] (August 1990).

6. Djoghlaf, Ahmed, Climate Change and Biodiversity in Polar Regions, Sustainable Development Law \& Policy, Vol. 8, Issue 3 (Spring 2008), at $14-16$.

7. Genest, A., The fight against global warming: progress made and priorities for a successor to the Kyoto Protocol, La Revue Juridique Thémis, 46: at 525-579 (2012).

8. Gruskin, Sofia \& Ray, Madhury, Climate Change and Human Rights: Roles, Responsibilities and Actions, Human Rights Defender, Vol. 23, Issue 1 (April 2014), at 14-16.

9. Hester, Tracy D., A Matter of Scale: Regional Climate Engineering and the Shortfalls of Multinational Governance, Carbon \& Climate Law Review, Vol. 2013, Issue 3 (2013), at 168-176.

10. Hsu, Shi-Ling, Climate Change Regulation and Prediction Markets: An Impartial Party - The Market - Can Weigh in on the Climate's Future, Regulation, Vol. 37, Issue 2 (Summer 2014), at 34-39.

11. Jarso, James Forole, Africa and the Climate Change Agenda: Hurdles and Prospects in Sustaining the Outcomes of the Seventh African Development Forum, Sustainable Development Law \& Policy, Vol. 11, Issue 2 (Winter 2011), at 38-44. 
12. Jarso, James Farole, The East African Community and the Climate Change Agenda: An Inventory of the Progress, Hurdles, and Prospects, Sustainable Development Law \& Policy, Vol. 12, Issue 2 (Winter 2012), at 19-24.

13. Johnson, C. Don, Toward Self-Determination-A Reappraisal as Reflected in the Declaration on Friendly Relations, 3 GA. J. INT'L \& COMP. L. 145 (1973).

14. Kasotia, Paritosh, The Health Effects of Global Warming - Developing Countries Are the Most Vulnerable, United Nations Chronicle, 44 U.N. Chron. 48 (2007).

15. Kawaley, Ian, Implications of the Exclusive Economic Zone and EEZ Management for Seychelles, a Small Midocean Commonwealth Territory, 29 OCEAN DEV. \& INT’L. L. 225 (1998).

16. Knox, John H., Human Rights, Environmental Protection, and the Sustainable Development Goals, 24 Wash. Int'l L.J. 517, 519 (2015).

17. Lash, Joseph P, Hammarskjöld's Conception of His Office, 16 INT'L ORGANIZATION 550 (1962-63).

18. Leal-Arcas, Rafael, Climate Change Mitigation from the Bottom Up: Using Preferential Trade Agreements to Promote Climate Change Mitigation, Carbon \& Climate Law Review, Vol. 2013, Issue 1 (2013), pp. 34-42

19. Levmore, Saul, Changes, Anticipations, and Reparations, Columbia Law Review, Vol. 99, Issue 7 (November 1999), at 1657-1700.

20. Lian, Koh Kheng \& Bhullar, Lovleen, Governance on Adaptation to Climate Change in the Asean Region, Carbon \& Climate Law Review, Vol. 2011, Issue 1 (2011), at 82-90.

21. Lin, Jolene, Litigating Climate Change in Asia, Climate Law, Vol. 4, Issue 12 (2014), at 140-149.

22. Masur, Jonathan S. \& Posner, Eric A., Toward a Pigouvian State, University of Pennsylvania Law Review, Vol. 164, Issue 1 (December 2015), at 93-148.

23. McCright, Aaron M.\& Dunlap, Riley E Challenging Global Warming as a Social Problem: An Analysis of the Conservative Movement's CounterClaims, Social Problems, Vol. 47, Issue 4 (November 2000), at. 499-522, 47 Soc. Probs. 499 (2000). 
24. Nanda, Anjail D., India's Environmental Trump Card: How Reducing Black Carbon through Common but Differentiated Responsibilities Can Curb Climate Change, Denver Journal of International Law and Policy, Vol. 39, Issue 3 (Summer 2011), at 523-552.

25. Nanda, Ved P., The Mounting Environmental Challenges, the United Nations Environment Programme, and the Reform of the International Environmental Governance Regime, University of Hawai'i Law Review, Vol. 35, Issue 2 (Spring 2013), at 539-558.

26. Nanda, Ved P., Climate Change and Developing Countries: The International Law Perspective, ILSA Journal of International and Comparative Law, Vol. 16, Issue 2 (Winter 2010), at 539-556.

27. Nanda, Ved P., The Kyoto Protocol on Climate Change and the Challenges to Its Implementation: A Commentary, Colorado Journal of International Environmental Law and Policy, Vol. 10, Issue 2 (Summer 1999), at 319-334.

28. Nanda, V.P., Global warming and international environmental law -- a preliminary inquiry, Harvard International Law Journal, 30: at 375-392 (1989).

29. Naser, Mostafa Mahmud, Preventing Climate-Induced Displacement in Bangladesh Through Strengthening Adaptation Strategies, Lawasia Journal, Vol. 2013, at 73-90.

30. Naser, Mostafa Mahmud, Climate-Induced Displacement in Bangladesh: Recognition and Protection under International Law, Nordic Journal of International Law, Vol. 82, Issue 4 (2013), at 487-528.

31. Naser, Mostafa Mahmud \& Afroz, Tanzim, Human Rights Implications of Climate Change Induced Displacement, Bond Law Review, Vol. 21, Issue 3 (2009), at [i]-153.

32. Nash, Jonathan Remy, Standing and the Precautionary Principle, Columbia Law Review, Vol. 108, Issue 2 (March 2008), at 494-528

33. Nayar, M. G. Kaladharan, Dag Hammarskjöld and U Thant: The Evolution of their Office, CASE W. RES. J. INT'L L., VOL. 7, NO. 1, at 37 (WINTER 1974).

34. Nayar, M. G. Kaladharan, Self-Determination Beyond the Colonial Context: Biafra in Retrospect, 10 TEX. INT'L L. J. 321 (1975). 
35. Nishimura, Lauren, Climate Change Migrants: Impediments to a Protection Framework and the Need to Incorporate Migration into Climate Change Adaptation Strategies, International Journal of Refugee Law, Vol. 27, Issue 1 (2015), at 107-134.

36. Oulu, Martin O., Mainstreaming Climate Adaptation in Kenya, Climate Law, Vol. 2, Issue 1 (2011), at 375-394.

37. Powers, Ann, Sea-Level Rise and Its Impact on Vulnerable States: Four Examples, Louisiana Law Review, Vol. 73, Issue 1 (Fall 2012), at 151-174.

38. Purdy, Jedediah, The Politics of Nature: Climate Change, Environmental Law, and Democracy, Yale Law Journal, Vol. 119, Issue 6 (April 2010), at 1122-1209.

39. Revesz, Richard L., Environmental Regulation, Cost-Benefit Analysis, and the Discounting of Human Lives, Columbia Law Review, Vol. 99, Issue 4 (May 1999), at 941-1017.

40. Richardson, Benjamin J., The Evolving Marketscape of Climate Finance, Climate Law, Vol. 4, Issue 1-2 (2014), at 94-106.

41. Robinson, Mary, Justice, Human Rights, and Climate Change [comments] Fletcher Forum of World Affairs, Vol. 39, Issue 2 (Summer 2015), 9-12.

42. Rosenstock, Robert, The Declaration of Principles of International Law Concerning Friendly Relations: A Survey, 65 AM. J. INT'L L. 713 (1971).

43. Ruhl, J. B., The Political Economy of Climate Change Winners, Minnesota Law Review, Vol. 97, Issue 1 (November 2012), at 206-277.

44. Saba, Alexis, Biasutti, Michela, Gerrard, Michael B., \& Lobell, David B., Getting ahead of the Curve: Supporting Adaptation to Long-Term Climate Change and Short-Term Climate Variability Alike, Carbon \& Climate Law Review, Vol. 2013, Issue 1 (2013), at 3-23.

45. Sari, Diah Apriani Atika \& Indriyani, Rachma, Loss and Damage due to Climate Change in Indonesia: An Overview of the ASEAN Cooperation Adapting to Global Warming, ndonesian Journal of International Law, Vol. 12, Issue 3 (April 2015), at 382-398.

46. Sarwar, Golan Mahabub \& Mamunul H. Khan, Sea Level Rise: A Threat to the Coast of Bangladesh, 38 INTERNATIONALES ASIENFORUM 375 (2007). 
47. Schwelb, Egon, The International Court of Justice and the Human Rights Clauses of the Charter, 65 AM. J. INT'L L. 337 (1972).

48. Sindico, Francesco, Climate Change: A Security (Council) Issue, Carbon \& Climate Law Review, Vol. 2007, Issue 1 (2007), at 29-34.

49. Smith, Don C., Special Issue: Climate Change Justice: Challenges and Opportunities: Editorial, Journal of Energy and Natural Resources Law, Vol. 34, Issue 1 (February 2016), 1-4, DOI: 10.1080/02646811.2016.1133985.

50. Stack, Kevin M. \& Vandenbergh, Michael P., The One Percent Problem, Columbia Law Review, Vol. 111, Issue 7 (November 2011), at 1385-1443.

51. Stewart, Richard B., Environmental Regulation and International Competitiveness, Yale Law Journal, Vol. 102, Issue 8 (1993), at 2039-2106.

52. Stone, C.D., Beyond Rio: “insuring against global warming”, American Journal of International Law, 86: at 445-488 (1992).

53. Sunstein, Cass R., Beyond the Precautionary Principle, University of Pennsylvania Law Review, Vol. 151, Issue 3 (January 2003), at 1003-1058.

54. Super, David A., From the Greenhouse to the Poorhouse: Carbon-Emissions Control and the Rules of Legislative Joinder, University of Pennsylvania Law Review, Vol. 158, Issue 4 (March 2010), at 1093-1198.

55. Weiss, Edith Brown, Environmentally Sustainable Competitiveness: A Comment, Yale Law Journal, Vol. 102, Issue 8 (1993), at 2123-2142.

56. Wiener, Jonathan Baert, Global Environmental Regulation: Instrument Choice in Legal Context, Yale Law Journal, Vol. 108, Issue 4 (January 1999), at 677-800.

57. Wilensky, Meredith, Climate Change in the Courts: An Assessment of NonU.S. Climate Litigation, Duke Environmental Law \& Policy Forum, Vol. 26, Issue 1 (Fall 2015), at 131-179. 


\section{INTERNET SITES}

1. AMNESTY INTERNATIONAL

https://www.amnesty.org/en/latest/campaigns/2015/12/climate-changehuman-rights/

(last visited April 29, 2017).

2. Bangladesh, NATiOnAl AdAPtATiOn PRogramme of ACtion (2005), https://unfccc.int/resource/docs/napa/ban01.pdf

(last visited May 22, 2017).

3. BANGLADESH, U.S. GEOLOGICAL SURVEY WORLD ENERGY ASSESSMENT

TEAM, BANGLADESH: AsSESSMENT RESUlTS SUMMARY - ALlOCATED

RESOURCES (2000), Bangladesh, USGS,

https://certmapper.cr.usgs.gov/data/PubArchives/WEcont/regions/reg8/

r8bang.pdf

(last visited May 22, 2017).

4. BANGLADESH, MiniSTRY OF ENV'T \& FOREST GOV'T OF THE PEOPLE'S

REPUBLIC OF BANGLADESH, NATIONAL ADAPTATION PROGRAMME

OF ACTION 2 (2005),

https://unfccc.int/resource/docs/napa/ban01.pdf

(last visited May 24, 2017).

5. (BANGLADESH) Syed S. Husain \& Hugh R. Tinker, Bangladesh,

ENCYCLOPAEDIA BRITANNICA

(last updated: Apr. 6, 2017),

https://www.britannica.com/place/Bangladesh

(last visited May 18, 2017).

6. CENTER FOR ECONOMIC \& SOCIAL RIGHTS,

The Post-2015 Agenda Won't Deliver Without Human Rights at the

Core, CENTER FOR ECON. \& SOC. RTS. (Sep. 29, 2014),

http://www.cesr.org/post-2015-agenda-wont-deliver-without-human-rights-

core (last visited Jul. 18, 2017).

7. COMMitTeE On ECONOMiC, SOCIAL, AND Cultural Rights, ECONOMIC AND SOCIAL COUNCIL, UNITED NATIONS

General Comment No. 15:

The right to water (arts. 11 and 12 of the International Covenant on

Economic, Social and Cultural Rights), January 20, 2003,

U.N. Doc. E/C.12/2002/11, I] 3, http://www2.ohchr.org/english/issues/water/docs/CESCR_GC_15.pdf (last visited May 18, 2018). 
8. COMMITTEE ON ECONOMIC, SOCIAL, AND CULTURAL RIGHTS, ECONOMIC AND SOCIAL COUNCIL, UNITED NATIONS,

Report on the Twentieth and Twenty-First sessions, 26 April-14 May1999, November 15 - 3 December 3, 1999,

Economic and Social Council, Official Record, 2000, United Nations, U.N. Doc. E/C.12/1999/11, II 204.

http://www.un.org/esa/documents/ecosoc/docs/2000/e2000-22.PDF

(last visited May 19, 2018).

9. GLOBAL WITNESS,

DEADLY ENVIRONMENT,

https://www.globalwitness.org/en/campaigns/environmental-activists/deadlyenvironment/

(last visited Jul. 28, 2017)).

10. GREENPEACE

The Climate Change and Human Rights Petition

October 20, 2017

http://www.greenpeace.org/seasia/ph/press/releases/Worlds-largest-carbonproducers-ordered-to-respond-to-allegations-of-human-rights--abuses-fromclimate-change/The-Climate-Change-and-Human-Rights-Petition/ (last visited November 25, 2017).

\section{HUMAN RightS WATCH}

Submission on Climate Change and Child Rights to the OHCHR DECEMBER 22, 2016 5:46AM EST

https://www.hrw.org/news/2016/12/22/submission-climate-change-andchild-rights-ohchr

(last visited April 29, 2017).

12. INTERNATIONAL COUNCIL FOR SCIENCE (ICSU) \& INTERNATIONAL SOCIAL SCIENCE COUNCIL (ISSC)

Report of ICSU in partnership with ISSC https://www.icsu.org/cms/2017/05/SDG-Report.pdf (last visited May 14, 2018).

13. IUCN (INTERNATIONAL UNION FOR CONSERVATION OF NATURE) Species Extinction: The Facts (2007)

THE IUCN RED LIST OF THREATENED SPECIES https://cmsdata.iucn.org/downloads/species_extinction_05_2007.pdf (last visited Nov. 28, 2017)).

14. IPCC, INTERGOVERNMENTAL PANEL ON ClimAte CHANGE, https://www.ipcc.ch/ipccreports/tar/

(last visited Jun. 26, 2017). 
15. Knox, John H., UN Special Rapporteur, Mapping Report - 2014,

UNITED NATIONS MANDATE ON HUMAN RIGHTS AND THE

ENVIRONMENT,

http://srenvironment.org/mapping-report-2014-2/

(last visited Jul. 28, 2017).

16. (MALDIVES) The Editors of Encyclopædia Britannica, Maldives,

ENCYCLOPAEDIA BRITANNICA

(last updated: Jun. 6, 2016),

https://www.britannica.com/place/Maldives

(last visited May 16, 2017).

17. OECD, Erik Solheim, OECD Dev. Assistance Comm., Development

Co-operation Report 2013: Ending Poverty (Dec. 5, 2013),

http://www.oecd.org/development/dcr2013.htm

(last visited Jul. 17, 2017).

18. OECD, Gender equality and women's rights in the post-2015 agenda:

A foundation for sustainable development (2013),

http://www.oecd.org/dac/post-2015.htm

(last visited Jul. 17, 2017).

19. Report of the Preparatory Commission of the United Nations,

PC/EX/113/Rev. 1,

December 12, 1945,

https://digitallibrary.un.org/record/703121/files/PC_EX_113_Rev.1-EN.pdf

(last visited: Apr. 4, 2019).

20. Seychelles, MANGROVES FOR THE FUTURE,

http://www.mangrovesforthefuture.org/countries/members/seychelles

(last visited May 17, 2017).

21. (SEYCHELLES) Donald Lee Sparks, Seychelles, ENCYCLOPAEDIA

BRITANNICA (last updated: Apr. 12, 2017),

https://www.britannica.com/place/Seychelles

(last visited May 17, 2017).

22. SEYCHELLES, The Exclusive Economic Zone, THE GEOGRAPHY OF THE

SEYCHELLES,

http://www.seychelles.org/seychelles-info/geography-seychelles

(last visited May 17, 2017). 
23. (TuVAlu) Barrie K. Macdonald, Tuvalu, ENCYClOPAEDIA BRITANNICA (last updated: Jun. 3, 2016), https://www.britannica.com/place/Tuvalu (last visited May 15, 2017).

24. Tuvalu, A.J. Tilling \& E. Fihaki, Tuvalu NAT'L Biodiversity STRATEGY \& ACTION PLAN, FOURTH NATIONAL REPORT TO THE CONVENTION ON BIOLOGICAL DIVERSITY (2009), http://www.sprep.org/att/IRC/eCOPIES/Countries/Tuvalu/55.pdf (last visited May 16, 2017).

25. Tuvalu's National AdAPtation Programme of ACtion at 30 (2007), http://www.sids2014.org/content/documents/162NAPA.pdf (last visited May 16, 2017).

26. Tuvalu, Fishery Country Profile: Tuvalu, FOOD \& AGRIC. ORG. OF THE UNITED NATIONS (Apr. 2002), http://www.fao.org/fi/oldsite/FCP/en/TUV/profile.htm (last visited May 17, 2017).

27. UNITED NATIONS, Human Rights, https://www.un.org/en/sections/issues-depth/human-rights/ (last visited: Jun 2, 2019).

28. U.N., Edith Brown Weiss, Vienna Convention for the Protection of the Ozone Layer, AUDIOVISUAL LIBRARY OF INTERNATIONAL LAW, UNITED NATIONS, http://legal.un.org/avl/ha/vcpol/vcpol.html (last visited Mar. 2, 2017).

29. U.N., Joint Statement of the Chairpersons of the United Nations Human Rights Treaty Bodies on the Post-2015 Development Agenda, UNITED NATIONS HUMAN RIGHTS, OFFICE OF THE HIGH COMMISSIONER, (Jan. 18, 2015), http://www.ohchr.org/EN/NewsEvents/Pages/DisplayNews.aspx?

NewsID=15505

(last visited Jul. 25, 2017).

30. U.N., About UN Environment, UN, http://web.unep.org/about/who-we-are/overview (last visited Feb. 8, 2017).

31. U.N., PRESS RElEASE, May 9, 2019. https://www.un.org/press/en/2019/sga1872.doc.htm (last visited: Jul. 13, 2019). 
32. U.N., Resolutions, 66th session, GENERAL ASSEMBLY OF THE UNITED NATIONS, http://www.un.org/en/ga/66/resolutions.shtml (last visited Nov. 26, 2017).

33. U.N., Resolutions, 70th session, GENERAL ASSEMBLY OF THE UNITED NATIONS, http://www.un.org/en/ga/70/resolutions.shtml (last visited Nov. 26, 2017).

34. United NAtions, The Sustainable DEVElopMent GoAls REPORT 2019, https://unstats.un.org/sdgs/report/2019/The-Sustainable-Development-GoalsReport-2019.pdf (last visited: Jul. 19, 2019).

35. Ban Ki Moon's Observations on Current State of Sustainability Goals. More Needs to be Done to Carry Out Sustainability Goals, Says Former UN Chief Ban Ki Moon, https://www.cnbc.com/2019/03/28/former-un-chief-ban-ki-moon-onsustainable-development-goals-sdg.html

36. U.N., The Sustainable Development Agenda, UNITED NATIONS, http://www.un.org/sustainabledevelopment/development-agenda/ (last visited Jul. 19, 2017).

37. U.N. Development Programme, Human Development Report 1990 (May 1, 1990), http://hdr.undp.org/sites/default/files/reports/219/hdr_1990_en_complete _nostats.pdf (last visited Jul. 19, 2017).

38. United Nations Conference on Sustainable Development, Rio+20, Sustainable DeVElopMENT KNOWLEDGE PlATFORM, https://sustainabledevelopment.un.org/rio20.html (last visited Mar. 11, 2017).

39. John H. Knox, UN Special Rapporteur, Mapping Report - 2014, UNITED NATIONS MANDATE ON HUMAN RIGHTS AND THE ENVIRONMENT: http://srenvironment.org/mapping-report-2014-2/, (last visited Nov. 12, 2017). 
40. U.N. Secretary General's High Level Panel of Eminent Persons on the Post-2015 Development Agenda, A New Global Partnership: Eradicate Poverty and Transform Economies Through Sustainable Development (May 30, 2013),

https://sustainabledevelopment.un.org/index.php?page=view \&type $=400$ $\& n r=893 \&$ menu $=1561$

(last visited Jul. 25, 2017).

41. WCED, REPORT OF THE WORLD COMMISSION ON ENVIRONMENT AND DEVELOPMENT: OUR COMMON FUTURE, http://www.un-documents.net/our-common-future.pdf (last visited Feb. 8, 2017). 